Portland State University

PDXScholar

\title{
Assessment of TMDL Implementation and Water Quality Status and Trends in Amazon Creek and Coyote Creek Watersheds
}

Stosh Zydek

Portland State University

Follow this and additional works at: https://pdxscholar.library.pdx.edu/mem_gradprojects

Part of the Environmental Indicators and Impact Assessment Commons, Environmental Monitoring Commons, and the Water Resource Management Commons Let us know how access to this document benefits you.

\section{Recommended Citation}

Zydek, Stosh, "Assessment of TMDL Implementation and Water Quality Status and Trends in Amazon Creek and Coyote Creek Watersheds" (2016). Master of Environmental Management Project Reports. 49. https://pdxscholar.library.pdx.edu/mem_gradprojects/49 https://doi.org/10.15760/mem.51

This Project is brought to you for free and open access. It has been accepted for inclusion in Master of Environmental Management Project Reports by an authorized administrator of PDXScholar. Please contact us if we can make this document more accessible: pdxscholar@pdx.edu. 


\section{Assessment of TMDL Implementation and Water Quality Status and Trends in Amazon Creek and Coyote Creek Watersheds}


This report prepared by:

Stosh Zydek

Graduate Student

Portland State University

Reviewed by:

Joseph Maser, Ph.D., Assistant Professor, Portland State University

Daniel Sobota, Ph.D., Water Quality Analyst, Oregon Department of Environmental Quality

Eugene Foster, Ph.D., Manager, Watershed Management, Oregon Department of Environmental Quality 


\section{Acknowledgments}

Many organizations assisted in the development of this project and data from many different sources were considered. Collection of and the understanding of information received throughout this project could not have been achieved without their assistance and advice on data acquisition and analyses and conveyance of information included within. Funding for this project was provided by ODEQ (US EPA 310 Grant) and Portland State University I would like to acknowledge the assistance of the following organizations, agencies, and the people within:

- Portland State University

- Joseph Maser

- Oregon Department of Environmental Quality

- Daniel Sobota

$\circ$ Eugene Foster

- Ryan Michie

- Pamela Wright

- Aaron Borisenko

- Michael Mulvey

- Koto Kishida

- Martin Mills

- Larry Caton

- Nick Haxton

- City of Eugene

- Therese Walch

- Thomas Mendes

- City of Eugene Environmental Services Department

- Lane County

- Pete Sorenson

- Daniel Hurley

- Lance County Environmental Services Department

- Long Tom Watershed Council

- Oregon Department of Agriculture

- Paul Measeles

- Oregon Watershed Enhancement Board

o Ken Fetcho 


\section{Acronyms}

AgWQMPs Agricultural Water Quality Management Area Plans

BLM

Bureau of Land Management

BOD Biological Oxygen Demand

CAFO Confined Animal Feeding Operation

COD Chemical Oxygen Demand

DMAs Designated Management Agencies

DO Dissolved Oxygen

ESM Environmental Sciences and Management

FPA Forest Practices Act

MEM Masters of Environmental Science

NPDES National Pollutant Discharge Elimination System

OAR Oregon Administrative Rule

ODA Oregon Department of Agriculture

ODEQ Oregon Department of Environmental Quality

ODF Oregon Department of Forestry

PSU Portland State University

SOD Sediment Oxygen Demand

SWCD Soil Water Conservation District

TMDLs Total Maximum Daily Loads

USFS United States Forest Service

WQMPs Water Quality Management Plans

WQRP Water Quality Restoration Plans 


\section{Executive Summary}

In this project, I analyzed the status and trends of water quality data describing fecal bacteria ( $E$. coli) and DO in the Amazon and Coyote Creek watersheds of the Southern Willamette Valley, Oregon. I also examined TMDL implementation plans produced by DMAs, determined if and how implementation activities corresponded to changes in water quality, compared management and planning of DMAs in the watersheds, discussed aspects of the current TMDL, and compared state regulations and standards in other states. I concluded by making management recommendations to better facilitate future status and trend analysis.

Amazon Creek, Amazon Diversion Channel, A-3 Drain, and Coyote Creek are listed year-round on Oregon's Category 4A 303(d) list for exceeding State bacteria criterion for E. coli. Upper Amazon Creek, Amazon Diversion Channel, and Coyote Creek are listed on Oregon's 303(d) Category 4A list for exceeding the State DO criteria. These stream segments were separated by watershed (Upper Amazon Creek, Lower Amazon Creek, and Coyote Creek) and analyzed at each sample station and as a whole with available data.

Ultimately, the lack of data hindered my status and trend analyses. However, existing data indicated Upper Amazon Creek and Coyote Creek continue to be impaired for DO, while DO concentrations in Lower Amazon Creek have increased above state single sample exceedance criterion for cool water $(5.0 \mathrm{mg} / \mathrm{L})$. The current protocol for monitoring bacteria and DO in these streams makes detecting exceedances difficult. The sample stations and seasons which are near exceedances can only be assumed to exceed 7-day criterion because grab sampling does not necessarily capture the lowest level of DO nor the highest level of bacteria concentration on the day of sampling. Sparse grab samples only convey instantaneous measures, which makes detailed assessments of seasonal or annual trends in water quality incomplete.

Coyote Creek had not been tested for TMDL-related water quality parameters since 2003 until sample collection was conducted as part of this project by ODEQ during the summer of 2015. Data obtained through the 2015 collection could therefore only be used to help inform the current status of water quality. Furthermore, the A-3 Drain allocated bacteria concentration reduction set by ODEQ (decrease 33\%) was determined from data taken during December of 2002. The allocated reduction percentage was difficult to analyze due to the season which reduction was calculated for. Bacteria concentration reduced by $48 \%$ overall, on average, when comparing data collected before and after 2008, but when comparing data collected after December of 2002 until present, during late October through the end of December, E. coli concentration only decreased by $3 \%$. It is recommended that the TMDL be reassessed to minimize any confusion toward the allocated reduction percentages.

DMAs in the Amazon and Coyote Creek watersheds have implemented BMPs or water quality management actions for decades prior to TMDL issuance, and have continued those actions. Therefore, analyzing and linking any water quality trends before and after the 2008 TMDL could not be directly attributed to specific implementation activities. The paucity of data and sample stations also minimized the ability to understand pollutant sources, loading locations, and trends in water quality data. If data are to be used to assess water quality status and trends or determine if TMDL implementation activities are achieving load allocations, sampling procedures and requirements in both Amazon Creek and Coyote Creek watersheds needs to be improved. Neither Amazon Creek nor Coyote Creek had flow measurements. Without flow measurements, agencies cannot assess where specific loading is occurring nor whether certain areas are affected during high flow events or low flow events. Using seasonality as a surrogate for flow measurements does not portray possible rain or system flush events. 
Based on my analysis, I recommend that TMDL implementation plans require DMAs to describe specific responses anticipated for implementation activities and timelines for attainment to each implementation activity. This would help ODEQ as well as DMAs assess implementation success and areas for improvement. In order to fully achieve these objectives, updates to ODEQ and DMA data collection requirements for 303(d) listings are needed by increasing data collection and the number of sampling sites. 


\section{Table of Contents}

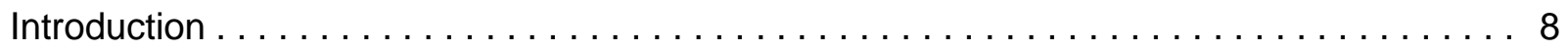

Watershed Overview ................................ 9

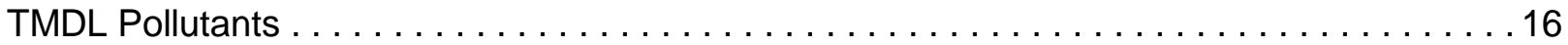

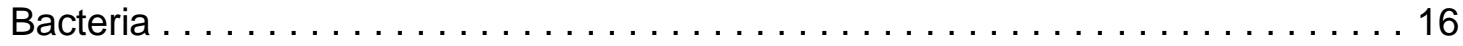

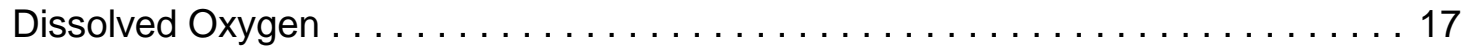

Willamette Basin (WQMP) . . . . . . . . . . . . . . . . . . . . . . . . . . 19

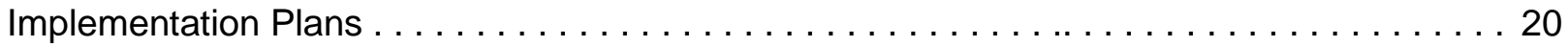

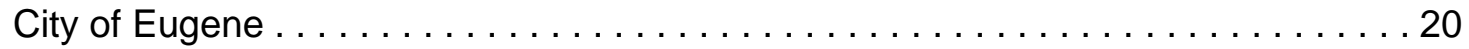

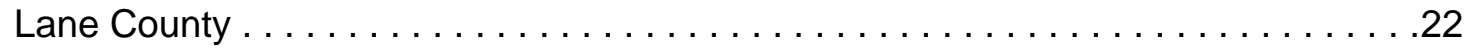

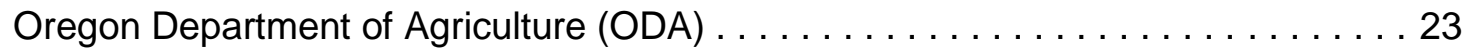

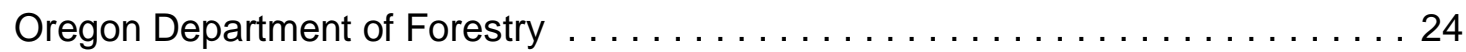

Water Quality Analysis . . . . . . . . . . . . . . . . . . . . . . . . . . . 24

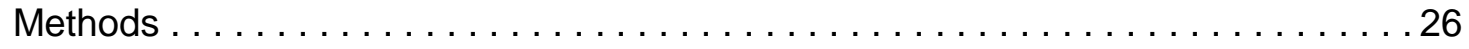

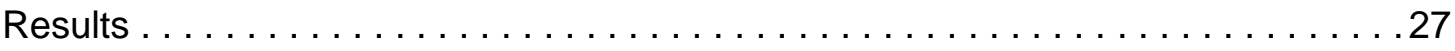

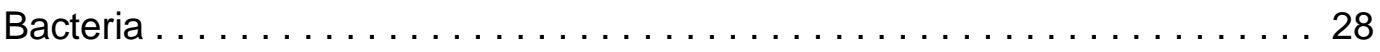

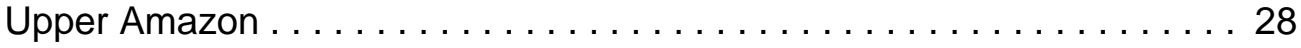

Lower Amazon . . . . . . . . . . . . . . . . . . . . . . 39

Coyote Creek .......................... 42

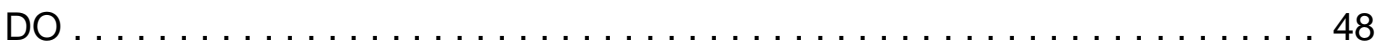

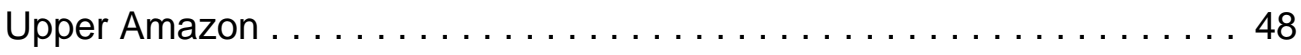

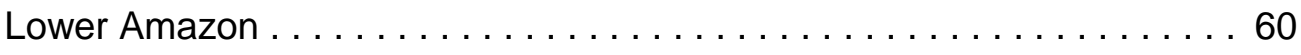

Coyote Creek............................ 63

Discussion . . . . . . . . . . . . . . . . . . . . . . 69

Management Recommendations .............................. 71

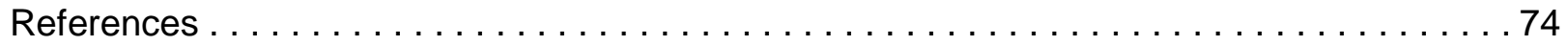

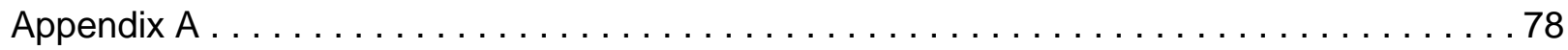

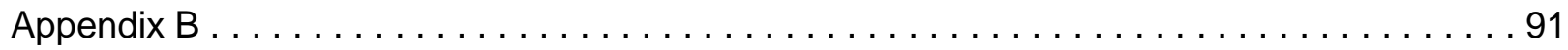

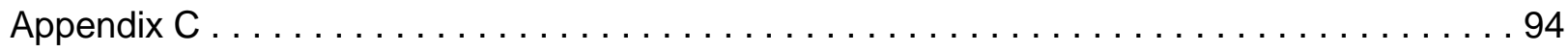

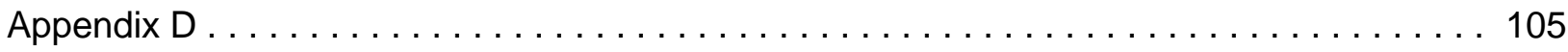

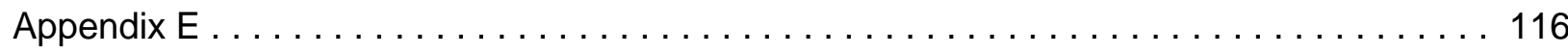

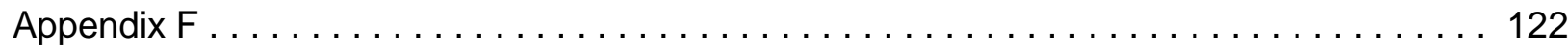




\section{Introduction}

In September 2006, the Oregon Department of Environment Quality (ODEQ) issued a pollution reduction plan for temperature, bacteria, dissolved oxygen (DO), turbidity, and mercury in the Willamette River Basin. ODEQ ordered the plan as a Total Maximum Daily Load (TMDL). A TMDL is a quantitative analysis for attaining and maintaining water quality standards (OAR 340042-0030(15)). In Oregon, ODEQ establishes sector and source-specific pollution reduction requirements needed to attain and maintain state water quality standards as part of a TMDL.

Oregon Administrative Rules OAR 340-042 sets forth the process for developing and implementing TMDLs and may be found on ODEQ's webpage:

http://arcweb.sos.state.or.us/pages/rules/oars 300/oar 340/340 042.html

Once a TMDL has been issued, Designated Management Agencies (DMAs)--government authorities with purview over specific land use/land cover types--submit an implementation plan designed to reduce nonpoint source (load) inputs to ODEQ for review and approval (OAR 340042-0080(4)). ODEQ is the DMA for point source (wasteload) inputs, and regulates pollution discharges through the following: National Pollutant Discharge Elimination System (NPDES) permitting; Water Pollution Control Facilities (WPCF) permitting; and enforcement of Municipal Separate Storm Sewer System (MS4) discharge permits. Each DMA is responsible for source assessment and identification, as well as identifying the appropriate management strategies that will be used to address source loading. The Oregon Department of Forestry (ODF) and Oregon Department of Agriculture (ODA) have Memorandums of Understanding (MOUs) with ODEQ stating that each agency's administrative rules are designed to meet water quality standards. ODA implements their rules through their Agricultural Water Quality Management Plan (AgWQMP) and ODF implements their rules through their Forest Practices Act (FPA). Non-point source discharges of pollutants from forest operations on state or private lands are subject to best management practices (BMPs) and other control measures established by ODF under ORS 527.610 to 527.992 and according to OAR 629-600 through 665 (OAR 340-042-0080(2)). Such forest operations, when conducted in good faith compliance with the FPA requirements, are assumed to meet water quality standards as provided in ORS 527.770. AgWQMPs and rules must be deemed by ODA to be sufficient to meet the TMDL load allocations and are subject to public comment by ODEQ (OAR 340-042-0080(3)).

Once load allocations have been estimated, ODEQ designs Water Quality Management Plans (WQMPs) to help DMAs develop and establish TMDL Implementation Plans. The implementation plans produced must identify management strategies used to achieve load allocations, provide a timeline to complete measurable goals, provide monitoring and a plan for periodic review and revision, provide evidence of compliance, and provide any other analyses or information specified in the WQMP produced by ODEQ (OAR 340-042-0080(4)).

Implementation plans augment previous management strategies designed to reduce pollutants established within the TMDL.

This project provides a comprehensive analysis of the types of strategies that DMAs in the Upper Willamette Basin, specifically Amazon Creek and Coyote Creek watersheds, committed to use for DO and bacterial pollution reductions in their 2008 implementation plans. I examined the successes and impediments to implementing those pollution reduction strategies up to 2015, and conducted a quantitative evaluation of the status, trends, and changes in water quality pre- and post- 2008. The Amazon Creek and Coyote Creek watersheds served as case studies for this project because they recently surpassed their 5-year TMDL review cycles, thus water quality and TMDL implementation data were readily available. Specific project objectives included: 
1) Describing current status and trends of DO and bacteria levels in Amazon and Coyote Creeks;

2) Determining if TMDL implementation and other management activities had influenced DO and bacteria levels in Amazon and Coyote Creeks; and,

3) Examining ways in which new data collection and stakeholder communication could improve adaptive management approaches for DO and bacteria TMDL implementation activities.

This project did not evaluate or establish compliance with issued permits or TMDL orders.

\section{Watershed Overview}

Amazon Creek and Coyote Creek watersheds are located in the Long Tom Watershed in the Southern Willamette Valley (Map 1 and 2). The Upper Amazon Creek Watershed drains 7,976 ha and the Lower Amazon Basin drains 7,807 ha (LTWC 2000). Amazon Creek originates in the hills south of Eugene at the peak of Spencer Butte, and flows through the southeastern and western portions of Eugene before entering flat agricultural land north of Eugene until draining into the Long Tom River. A-3 Drain conveys through urban, industrial, and rural residential areas (Map 3). Amazon Diversion Channel is fed from Amazon Creek and flows into Fern Ridge Reservoir. Willow Creek is a major tributary to Amazon Creek and drains primarily forest land and rural residential areas before it flows north and enters Amazon Creek, west of downtown Eugene.

The Coyote Creek watershed drains 26,952 ha (Willamette Basin TMDL, 2006). Coyote Creek is a tributary of the Long Tom River via Fern Ridge Reservoir (Map 4). Located southwest of the City of Eugene, Coyote Creek flows through semi-forested agricultural land. 


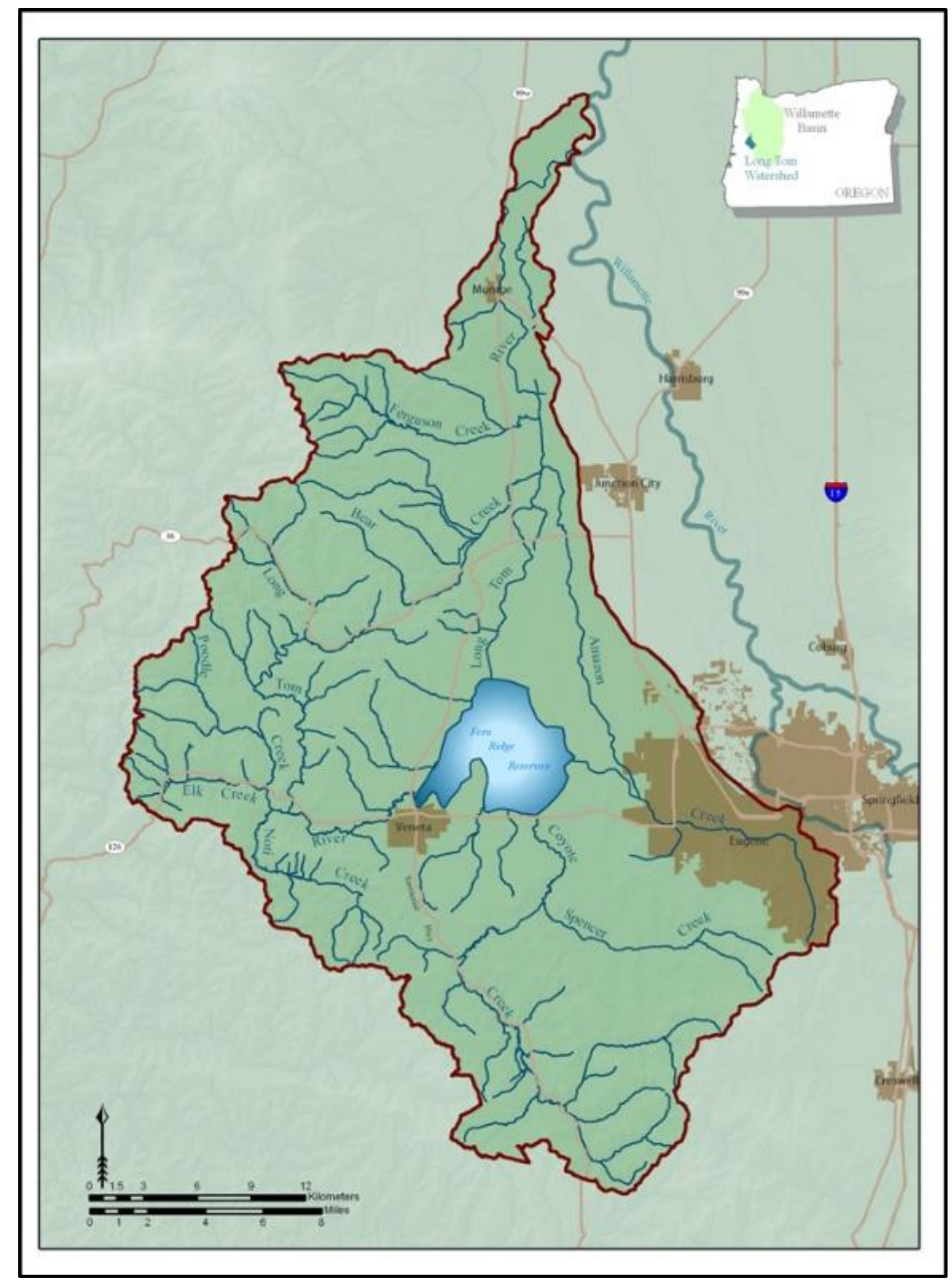

Map 1. (A \& B) Upper and Lower Amazon Creek and Coyote Creek watersheds located within Long Tom Watershed in the Southern Willamette Valley (Ecology and Society). 


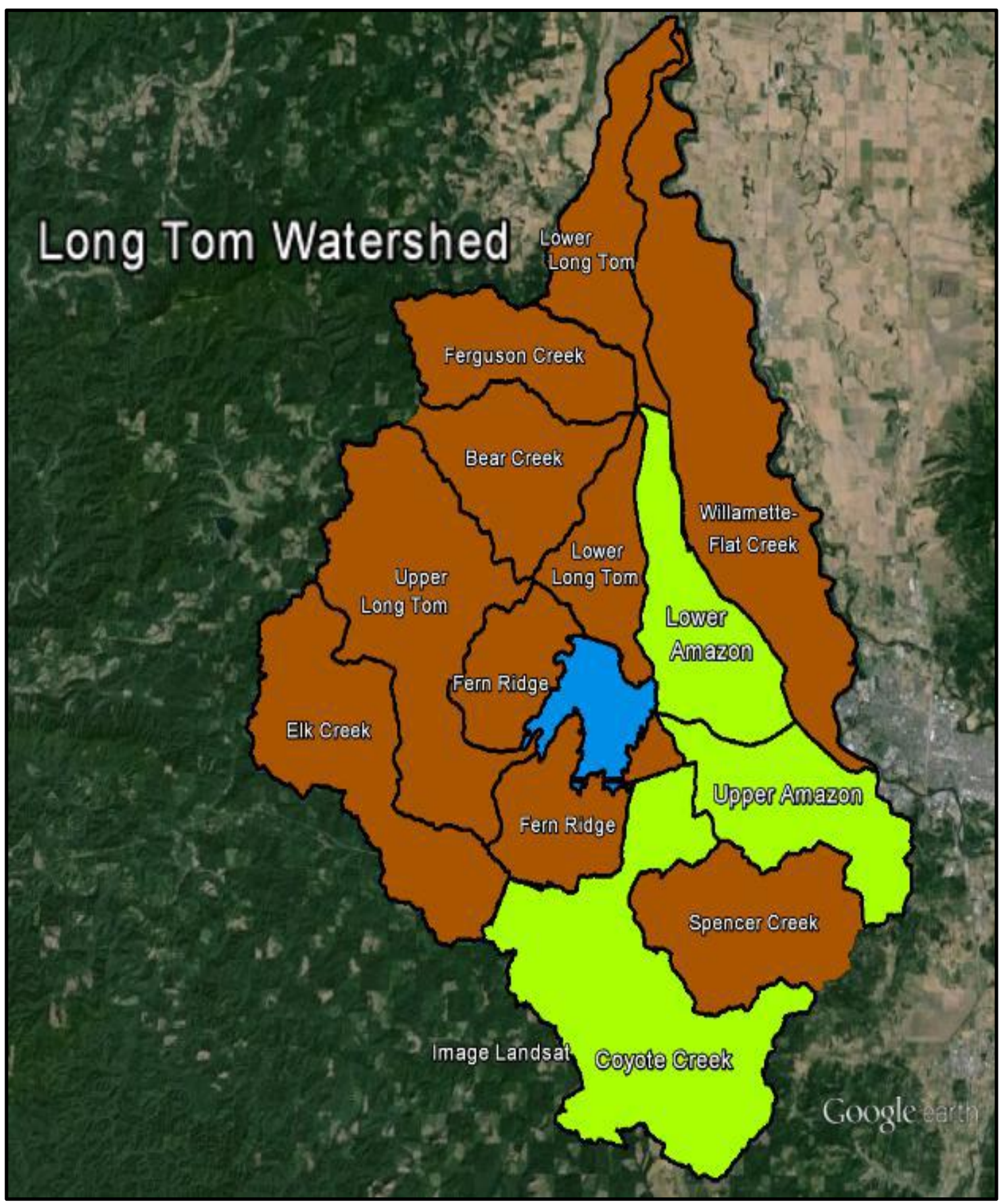

Map 2. Upper and Lower Amazon Creek and Coyote Creek watersheds located within Long Tom Watershed 


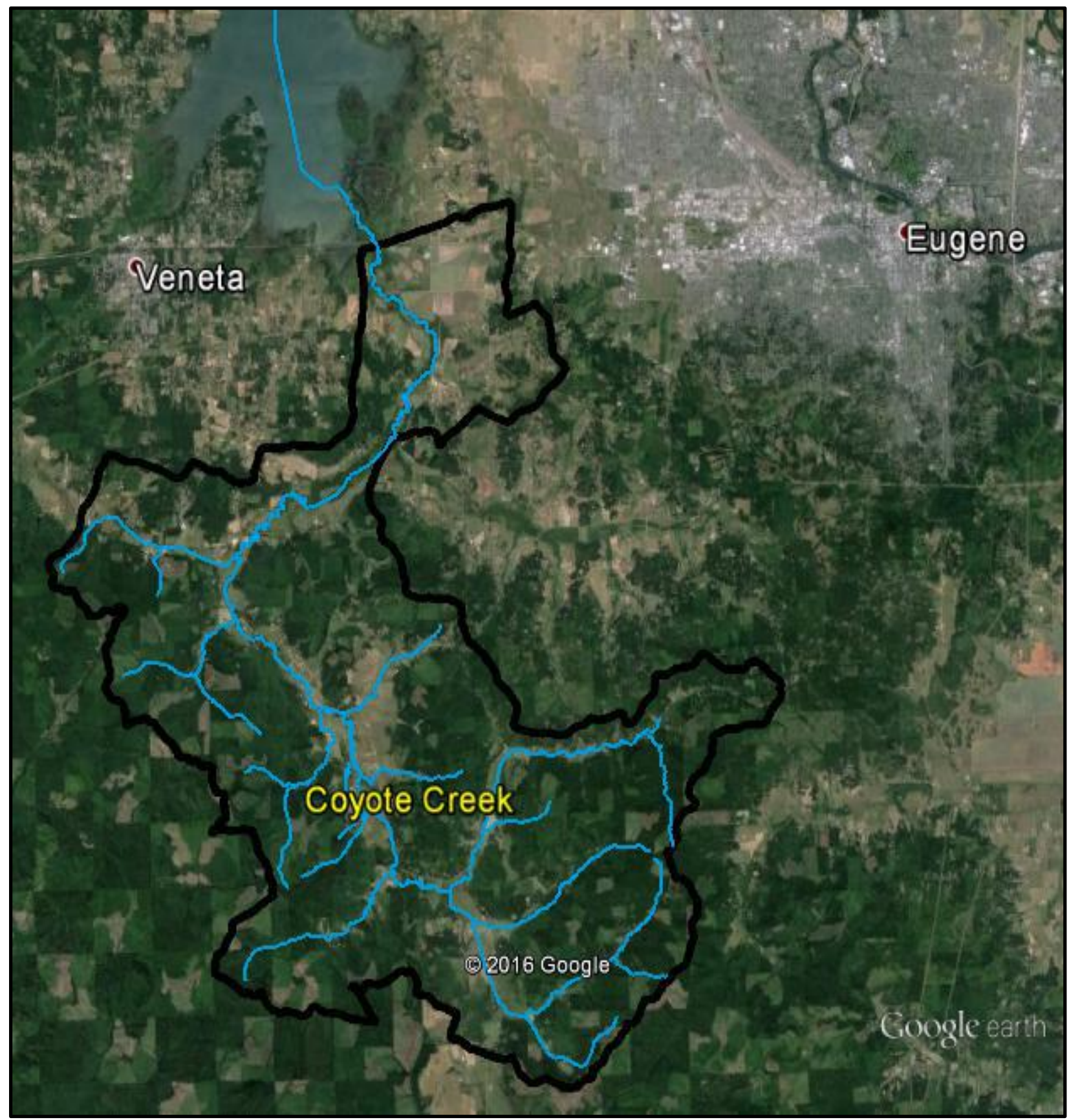

Map 4. Coyote Creek watershed 


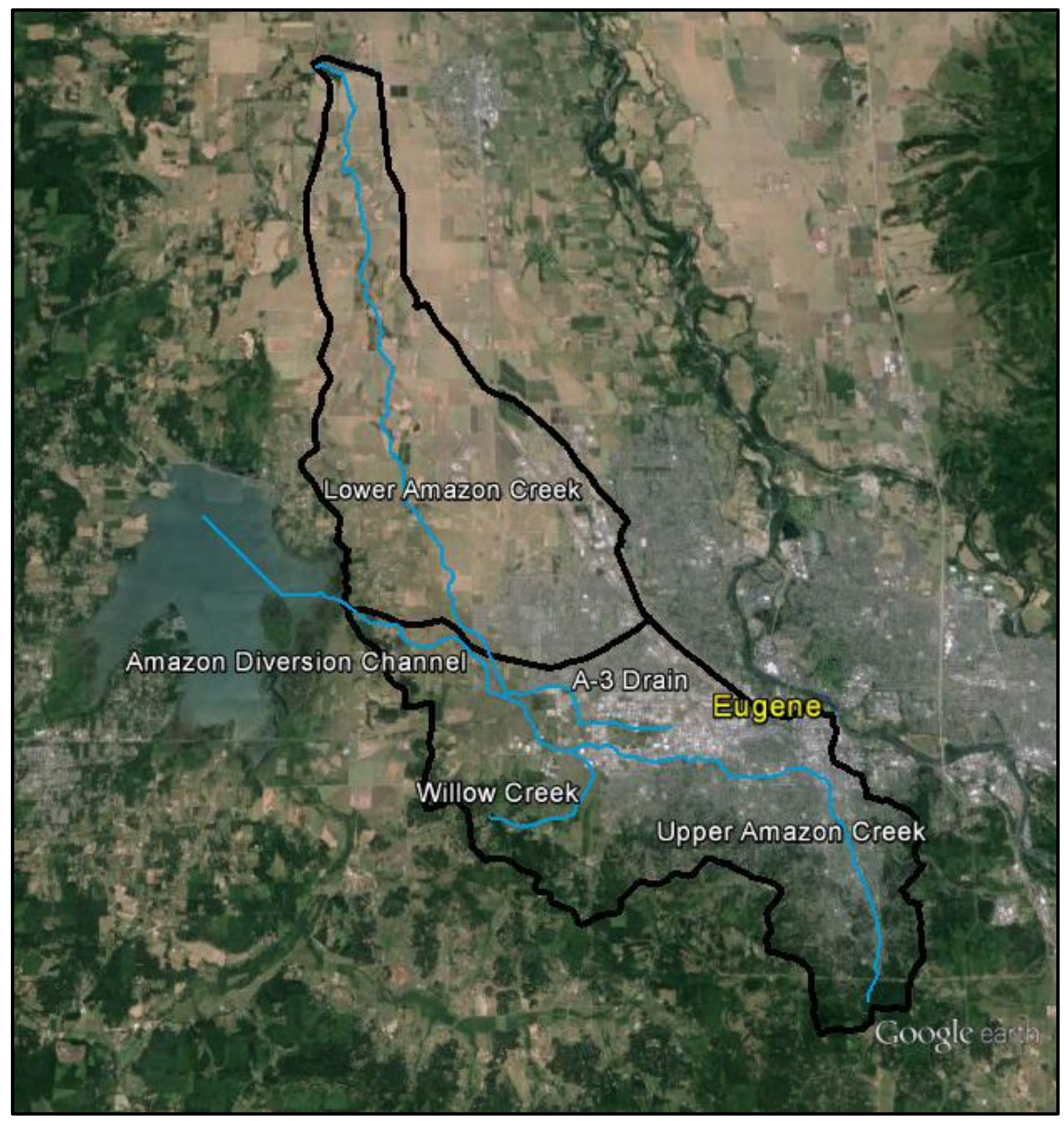

Map 3. Upper and Lower Amazon Creek watersheds.

The Upper Amazon Creek Basin consists of $80 \%$ urban, $7 \%$ rural residential, $6 \%$ forestry, and $6 \%$ agriculture land cover types as of 2006 (LTWC 2003) (Map 5). The largest urban portion of the watershed falls within the City of Eugene. The Lower Amazon consists of $62 \%$ agriculture, $21 \%$ urban, $6 \%$ rural residential, and $11 \%$ other land cover types as of 2006 (LTWC 2003). Land use in Coyote Creek is a mixture of forestry (59\%), agriculture (28\%), and rural residential land, (11\%) (LTWC 2003). Population density in Upper and Lower Amazon Creek was 10.6 people/hectare and 5.2 people/hectare, respectively, while Coyote Creek had 0.2 people/hectare as of 2010 (LTWC 2003). The majority of precipitation in the watersheds comes 
as rain. Precipitation ranges from 89 to $188 \mathrm{~cm} / \mathrm{yr}$ (LTWC 2003). Most of the precipitation falls from November through March and generally corresponds to increased stream flow (LTWC 2003). However, the largest storms tend to come in November and December, whereas peak stream flows come in December and January (LTWC 2003). This is because in early winter, soils are not saturated and there is little, if any, overland flow (LTWC 2003). Later in the winter, as soils become saturated, increased amounts of overland flow lead to higher stream flows (LTWC 2003). 
Long Tom Sub-Basins and Landuse

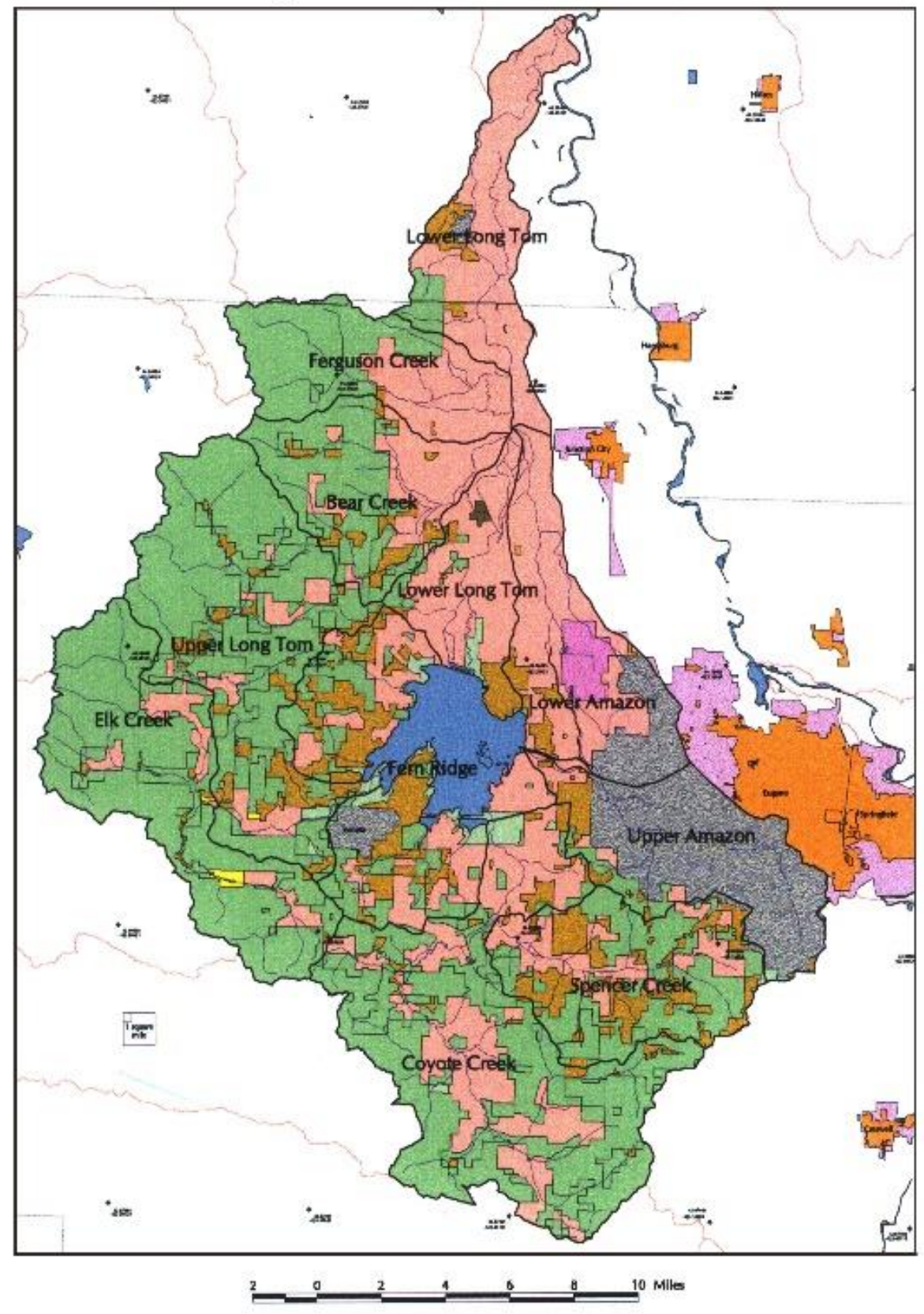

LEGEND

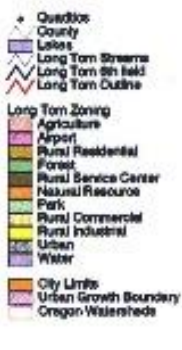

lansay 1998
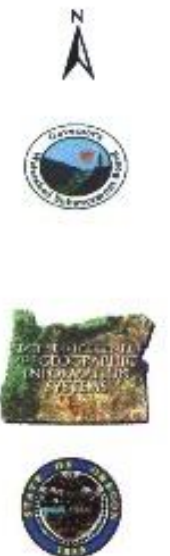

Long Ton Watershed Conucit

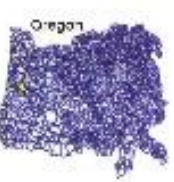

13

Map 5. Land Use Map of the Coyote and Amazon Creek basins (LTWC)

Downstream of Martin Street in Eugene, Amazon Creek has been extensively altered. Extensive channelization has occurred in the agricultural and urban portions of the watershed: $62 \%$ of the stream length in Lower Amazon and 36\% in Upper Amazon (LTWC 2000). Upper Amazon Creek channel modification includes $25 \mathrm{~km}$ of channelization, $9 \mathrm{~km}$ of streamside roads, two impoundments, one flow check dam, $13 \mathrm{~km}$ of levees, and $5 \mathrm{~km}$ of road crossings (LTWC 
2000). At 24th Avenue Amazon Creek enters a concrete-lined channel for $2.8 \mathrm{~km}$ before entering a trapezoidal levee channel at Jefferson Street, near the Lane County Fairgrounds. A diversion channel (Amazon Diversion Channel) connects the Fern Ridge Reservoir to Amazon Creek south of Royal Avenue. The construction of the Diversion Channel to Fern Ridge Reservoir took place between 1951 and 1958, with additional widening and deepening of the channel up to $33^{\text {rd }}$ and Hilyard Street, and the construction of the concrete channel between Jefferson and 24 ${ }^{\text {th }}$ Street (LTWC 2000). Lower Amazon Creek channel modification includes 69 $\mathrm{km}$ of channelization, $0.5 \mathrm{~km}$ of streamside roads, four impoundments, three quarries, and $2 \mathrm{~km}$ of road crossings (LTWC 2000).

The Coyote Creek watershed has 15 impoundments, which aside from Fern Ridge Reservoir located at the lower end of the watershed, are small agricultural impoundments used for livestock watering, fishponds, or unspecified domestic use (Willamette Basin TMDL, 2006). Coyote Creek channel modifications include: $30 \mathrm{~km}$ of channelization; $4 \mathrm{~km}$ of streamside roads; and $2 \mathrm{~km}$ of road crossings (LTWC 2000).

\section{TMDL Pollutants}

\section{Bacteria}

Coliform bacteria are a collection of microorganisms that live in the intestines of humans and animals (Oram 2014). Fecal coliform bacteria make up a specific subgroup of this collection, the most common of which is Escherichia coli (E. coli) (Oram 2014). Although these specific bacteria are generally not harmful, these microbes indicate the possible presence of pathogenic (disease-causing) bacteria, viruses, and protozoans (Oram 2014). The Environmental Protection Agency (EPA) recommends $E$. coli as the best indicator of health risk from water contact in recreational waters (EPA, 5.11 2012). When fecal bacteria numbers are above water quality standards, people exposed may exhibit fever, diarrhea, chest pains, abdominal cramps, and have an increased risk to gastrointestinal illnesses (Oram 2014).

Amazon Creek, Amazon Diversion Channel, A-3 Drain and Coyote Creek are listed year round on Oregon's Category 4A (water quality limited, TMDL approved) 303(d) list for exceeding state bacteria criteria for $E$. coli. The load capacity for bacteria is defined as a 30-day mean of $126 E$. coli counts per $100 \mathrm{~mL}$, based on a minimum of 5 samples, with no $90^{\text {th }}$ percentile calculation exceeding 406 E. coli counts per $100 \mathrm{~mL}$ (OAR 340-41-0009).

Fecal bacteria reach surface waters from a variety of non-point sources during both base flow and storm events (Willamette Basin TMDL, 2006). Upper Amazon loading sources include urban and rural residential runoff and waste from pets and wildlife. Lower Amazon and Coyote Creek loading sources are primarily rural residential runoff, wastes from pet, livestock, and wildlife, and failing septic systems. Based on NPDES permit compliance, ODEQ determined that point source discharges were not violating the terms of their NPDES permits for $E$. coli (Willamette Basin TMDL, 2006). There is one Confined Animal Feeding Operation (CAFO) in Coyote Creek watershed, located below the confluence of Spencer Creek. However, CAFOs are under NPDES permitting and therefore determined to be in compliance.

In the 2006 TMDL, ODEQ calculated percent reductions (allocations) by using a percentile of the measured concentrations that met the maximum criterion and the greatest reduction that resulted in meeting the log mean criterion (Willamette Basin TMDL, 2006). The greatest percent reduction needed to meet state criterion along the waterbody was applied to the entire waterbody as a conservative assumption to meet criteria along all sections of stream (Willamette Basin TMDL, 2006). The percent reductions of instream bacteria concentrations 
were applied to land-use specific categories: agriculture, forestry, and urban (Table 1). A margin of safety was applied through a conservative calculation of the $90^{\text {th }}$ percentile and log mean to compare the 126 E. coli counts per $100 \mathrm{~mL}$ 30-day log mean exceedance criterion (Willamette Basin TMDL, 2006). No reserve capacity was allotted for bacteria. Future permitted sources of bacteria will be required to meet the water quality criteria (Willamette Basin TMDL, 2006).

Wasteload allocations for NPDES permits were equivalent to the load capacity for a 30-day mean and an instantaneous limit of 406 E. coli counts per $100 \mathrm{~mL}$; CAFOs were allocated zero (Willamette Basin TMDL, 2006).

Table 1: Summary of percent reductions of bacteria loads required by the Willamette TMDL.

Table 1: Summary of percent reductions of bacteria loads required by the Willamette TMDL.
\begin{tabular}{|l|c|c|c|}
\hline Reach & Land Use & Percentage of Land Use & Percent Reduction \\
\hline Upper Amazon Creek (includes Diversion Channel) & $84 \%$ \\
\hline & Urban & $59 \%$ & $58 \%$ \\
\hline & Agriculture & $13 \%$ & $0 \%$ \\
\hline & Forest & $28 \%$ & $33 \%$ \\
\hline A-3 Drain & Urban & $59 \%$ & $33 \%$ \\
\hline & Agriculture & $41 \%$ & $66 \%$ \\
\hline Coyote Creek & Urban & $3 \%$ & $66 \%$ \\
\hline & Agriculture & $12 \%$ & $0 \%$ \\
\hline & Forest & $85 \%$ & \\
\hline
\end{tabular}

\section{Dissolved Oxygen}

DO in lakes, rivers, and streams is critical for aquatic life. Sufficient DO in water is needed by aerobic organisms, including microbes, macroinvertebrates, such as aquatic insects, and vertebrates, such as fish. A stream gains oxygen from physical exchange with the atmosphere and from plants via photosynthesis, while respiration by aquatic organisms, decomposition, and various chemical reactions consume oxygen (EPA, 5.2 2012). DO concentrations have both seasonal and diel fluctuations. Seasonally, DO concentrations are highest in winter and early spring, when water temperatures are lowest. DO concentrations tend to be lower in summer and fall when water temperatures are warm, although daily DO concentration maximums may exceed winter/spring daily averages due to high rates of primary production. Decreased DO levels may indicate organic matter or nutrient contamination and excess biological oxygen demand (BOD) (Oram 2014). Nutrients from agricultural and residential runoff stimulate aquatic plant growth, creating larger diel fluctuations. If the weather becomes cloudy for extended periods, plant respiration will exceed photosynthesis resulting in DO depletion (Oram 2014). When excessive aquatic plant growth senesces, resulting detritus decomposes and consumes DO (Oram 2014).

Upper Amazon Creek, Amazon Creek Diversion Channel, and Coyote Creek are listed on Oregon's Category 4A 303(d) list for exceeding the State DO criteria (Table 2). The Upper Amazon Creek and Amazon Diversion Channel have been designated by ODEQ as cool-water, while Coyote Creek has been designated as cold-water (Willamette Basin TMDL, 2006).

Table 2: Dissolved Oxygen Criterion (OAR 340-041-0016)

\begin{tabular}{|c|c|c|c|l|}
\hline Class & 30-day & 7-day & Min & \multicolumn{1}{c|}{ Use/Level of Protection } \\
\hline Cold Water & 8.0 & 6.5 & 6.0 & $\begin{array}{l}\text { Principally cold-water aquatic life. Salmon, trout, cold-water invertebrates, and } \\
\text { other native cold-water species exist throughout all or most of the year. } \\
\text { Juvenile anadromous salmonids may rear throughout the year. No } \\
\text { measurable risk level for these communities. }\end{array}$ \\
\hline Cool water & 6.5 & 5.0 & 4.0 & $\begin{array}{l}\text { Mixed native cool-water aquatic life, such as sculpins, smelt, and lampreys. } \\
\text { Waterbodies includes estuaries. Salmonids and other cold-water biota may be } \\
\text { present during part or all of the year but do not form a dominant component of } \\
\text { the community structure. No measurable risk to cool-water species, slight risk } \\
\text { to cold-water species present. }\end{array}$ \\
\hline
\end{tabular}


Point sources in Amazon Creek and Amazon Diversion Channel discharge via stormwater runoff (Willamette Basin TMDL, 2006). These facilities may contribute loads of oxygen demanding pollutants during rainfall events, but are otherwise not permitted to discharge to surface waters (Willamette Basin TMDL, 2006). ODEQ has determined that none of the point sources appear likely to discharge significant quantities of nutrients, including ammonia, or oxygen-demanding organic matter (Willamette Basin TMDL, 2006). NPDES permitted facilities do not exist within the Coyote Creek watershed; the CAFO shows no indication of violating the terms of its permit (Willamette Basin TMDL, 2006). ODEQ determined that low DO levels were due to riparian habitat degradation, high bacteria levels, excessive loads of suspended solids, excessive algal growth due to excessive solar radiation levels, high stream temperatures, and high nutrient concentrations (Willamette Basin TMDL, 2006). Lack of riparian habitat has caused the streams to warm above natural conditions, due to lack of shading, and has caused low nutrient retention in the riparian zone and high levels of in-stream algal growth (Willamette Basin TMDL, 2006).

ODEQ determined increasing shading would increase DO concentrations due to the reductions in stream temperature (Willamette Basin TMDL, 2006). ODEQ models indicated increasing shade from current conditions to system potential would reduce diel DO fluctuations (Willamette Basin TMDL, 2006). ODEQ determined if shading increased, standards for DO would be met without the need for additional reductions in BOD, nutrients, or SOD (Willamette Basin TMDL, 2006).

Load allocations for Amazon Creek and the Amazon Creek Diversion Channel aim to reduce BOD, SOD, and nutrient concentration by $40 \%$ and bring average solar radiation load to 421 Ly/day (Table 3) (Willamette Basin TMDL, 2006). In Coyote Creek above the Spencer Creek confluence, no reductions were required for BOD, nutrients or volatile suspended solids (Willamette Basin TMDL, 2006). Below the Spencer Creek confluence, where pollutant concentrations are high, $20 \%$ reductions in ammonia, BOD, nutrients, and SOD were designated (Willamette Basin TMDL, 2006). The load allocation for average solar radiation for Coyote Creek was 248.2 Ly/day (Willamette Basin TMDL, 2006). All specified concentration reductions were assigned to urban and agriculture land use categories because the analysis determined that forestlands did not contribute significantly to BOD, nutrient, and SOD concentration (Willamette Basin TMDL, 2006). Mandated concentration reductions for these pollutants apply year-round for both Coyote and Amazon Creek (Willamette Basin TMDL, 2006).

Table 3: Land-use based load allocations for the Amazon Creek and Coyote Creek watersheds.

\begin{tabular}{|c|c|c|c|c|}
\hline Watershed & $\begin{array}{l}\text { Land Use } \\
\text { Categories }\end{array}$ & $\begin{array}{l}\text { Percent of } \\
\text { Land Use }\end{array}$ & $\begin{array}{l}\text { Percent Reduction in ammonia, } \\
\text { BOD loads, nutrient loads, and SOD }\end{array}$ & Solar Radiation Load \\
\hline \multirow{3}{*}{ Amazon Creek } & Urban & $59 \%$ & $40 \%$ & \multirow{3}{*}{421 Ly/day } \\
\hline & Agriculture & $13 \%$ & $40 \%$ & \\
\hline & Forest & $28 \%$ & $0 \%$ & \\
\hline \multirow{3}{*}{$\begin{array}{c}\text { Coyote Creek } \\
\text { (below Spencer } \\
\text { Creek Confluence) }\end{array}$} & Urban & $3 \%$ & $20 \%$ & \multirow{3}{*}{248 Ly/day } \\
\hline & Agriculture & $12 \%$ & $20 \%$ & \\
\hline & Forest & $85 \%$ & $0 \%$ & \\
\hline
\end{tabular}

The TMDL did not include a reserve capacity. ODEQ determined the conservative margin of safety applied in establishing TMDL load allocations would effectively function as reserve capacity. The margin of safety (MOS) was included to account for uncertainty in the relationship between load allocations and water quality. Amazon Creek load allocations provide for margins of safety by: 
1.) Targeting cool-water $(5.0 \mathrm{mg} / \mathrm{L}$ minimum) rather than warm-water $\mathrm{DO}$ standards $(4.0$ $\mathrm{mg} / \mathrm{L}$ minimum);

2.) Basing load allocations for BOD, nutrients, and volatile suspended solids loads on loads needed to meet standards for the system potential shade condition; and,

3.) Setting the load capacity and required concentration reductions to $40 \%$. This was the upper range of required concentration reductions (Willamette Basin TMDL, 2006).

Coyote Creek load allocations provide for margins of safety by:

1.) Targeting cold-water rather than cool-water DO standards;

2.) Targeting a minimum $\mathrm{DO}$ concentration of $6.5 \mathrm{mg} / \mathrm{L}$ rather than $6.0 \mathrm{mg} / \mathrm{L}$; and,

3.) Providing an explicit $20 \%$ MOS for ammonia, BOD, and other parameters. This was meant to ensure that the TMDL would be protective of designated beneficial uses (Willamette Basin TMDL, 2006).

\section{Willamette Basin WQMP}

WQMPs describe the overall framework for TMDL implementation. These plans include activities, programs, legal authorities, and other measures by which ODEQ and other DMAs can regulate management activities. Entities identified as DMAs must develop and implement controls on non-point source pollution under their jurisdiction via a TMDL Implementation Plan. DMAs in the Amazon Creek and Coyote Creek watersheds include the City of Eugene, Lane County, ODA, Bureau of Land Management (BLM), US Forest Service (USFS), and ODF.

Federal lands fall under the purview of the BLM and USFS. These agencies have developed Water Quality Restoration Plans (WQRPs) equivalent to implementation plans. ODF is responsible for regulating non-point source pollutants resulting from forest operations on nonfederal forestlands. Surface waters in lands where forest operators conduct operations in accordance with the FPA are assumed to meet water quality standards.

ODA regulates agricultural activities that can affect water quality through the Agricultural Water Quality Management Act (SB1010). Senate Bill 502 and Senate Bill 1010 directed ODA to work with local communities, including farmers, ranchers, and environmental representatives, to develop AgWQMPs and rules in the Willamette Basin. Local management agencies, such as the Soil and Water Conservation Districts (SWCD) working under contract with ODA to conduct outreach and education, developed individual farm plans for operations in the planning area, worked with landowners to implement management practices, and helped landowners secure funding to cost-share water quality improvement practices.

ODEQ administers two different types of storm water permits based on population size. Phase 1 MS4 permits apply to jurisdictions with a population $>100,000$, while Phase 2 MS4 permits apply to jurisdictions with $>50,000$ but $<100,000$. The City of Eugene has a Phase 1 MS4 permit. Lane County has a Phase 2 MS4 permit. ODEQ expects DMAs covered by an MS4 permit to demonstrate that they will address temperature and non-point sources of TMDL pollutants not addressed by the MS4 storm water management plan. For any storm water management plan that covers all TMDL parameters, the storm water management plan would suffice as an implementation plan.

DMAs are required to address water quality protection through Statewide Planning Goals 5 and 6. Goal 5 requires all Oregon cities and counties to conserve open space and protect natural and scenic resources. Goal 6 requires management agencies to maintain and improve water quality. ODEQ believes public involvement is essential for successful water quality improvement (Willamette Basin TMDL, 2006). DMAs determine how public involvement within their 
jurisdictions is managed. DMAs must also provide monitoring efforts consisting of the following activities:

- Reports on the numbers and locations of projects;

- BMPs implemented and education activities completed;

- Water quality monitoring to assess the effectiveness of implementation activities and track progress toward achieving water quality numeric criterion; and,

- Monitoring riparian vegetation communities and shade to assess progress towards achieving system potential targets established in the TMDL.

DMAs will be expected to provide a fiscal analysis of the resources needed to develop, execute, and maintain the management strategies described in their implementation plans. Grants are available on a competitive basis for improvement projects. Agency personnel assist landowners in identifying, designing, and submitting eligible projects for these funds.

\section{Implementation Plans}

\section{City of Eugene}

\section{Planned to be Implemented}

The City of Eugene submitted a TMDL Implementation Plan to ODEQ in 2008. Eugene NPDES permits for point source discharges to Amazon Creek include Phase 1 MS4 permit and General $1200 Z$ Industrial Storm-water Permit for Eugene's Airport. These permits serve as the TMDL Implementation plans for the covered discharges (City of Eugene Oregon, 2006). The City received its first MS4 permit in 1994, their second-term permit in 2004, and their third-term permit was submitted in 2008. The General $1200 Z$ permit for Eugene Airport permits the discharges of storm-water runoff from the airport to Amazon Creek and A1 Channel (City of Eugene Oregon, 2006). Eugene plans to implement Goal 5 by protecting riparian areas, upland wildlife habitat areas, and wetlands. Eugene plans to implement Goal 6 by creating WQ (Water Quality) overlay zones for waterways with significant relationships to the 303(d) listed streams. The overlay zones would regulate uses and activities within and adjacent to impaired waterways.

Eugene's strategy for bacteria management includes eleven key strategies; eight from the Phase 1 MS4 permit; one focused upon non-point source/TMDL/Goal 6; one focusing upon Goal 5; and one focused upon the TMDL program (Table 4) (City of Eugene Oregon, 2006).

Table 4: City of Eugene bacteria strategy elements

\begin{tabular}{|c|c|}
\hline Bacteria Strategy Element & Governing Permit/Program \\
\hline 1. Education and outreach related & Phase 1 MS4 permit \\
\hline Field investigation program and illicit discharge programs & Phase $1 \mathrm{MS} 4$ permit \\
\hline Maintenance programs & Phase 1 MS4 permit \\
\hline Administer stormwater development standards & Phase 1 MS4 permit \\
\hline 5. Protection of riparian vegetation & Phase 1 MS4 permit \\
\hline 6. $\quad$ Monitoring & Phase 1 MS4 permit \\
\hline 7. Evaluate the effectiveness of the BMPs and bacteria pilot study & Phase 1 MS4 permit \\
\hline $\begin{array}{l}\text { 8. Comply with MS4 permit conditions related to TMDLs, including establishing } \\
\text { benchmarks and bacteria pollutant load reductions }\end{array}$ & Phase 1 MS4 permit \\
\hline 9. Establish setback buffers by means of a Water Quality Overlay Zone & Non-point source/ TMDL / Goal 6 \\
\hline 10. Track and support the implementation of natural resource waterway protections & Goal 5 \\
\hline $\begin{array}{l}\text { 11. Develop TMDL web page, including links to related web sites, the City's TMDL } \\
\text { Implementation Plan, and staff contact information }\end{array}$ & TMDL \\
\hline
\end{tabular}


Eugene's management strategy for DO consists of eleven key strategies; including eight from the Phase 1 MS4 permit and one each focusing upon the non-point source/TMDL/Goal 6 program, Goal 5, and the TMDL program (Table 5) (City of Eugene, Oregon, 2006).

Table 5: City of Eugene DO strategy elements

\begin{tabular}{|c|c|}
\hline DO Strategy Element & Governing Permit/Program \\
\hline $\begin{array}{l}\text { 1. Educational brochures and newsletters about causes of low DO and the actions private } \\
\text { landowners and businesses can take to minimize depletion of stream water DO }\end{array}$ & Phase 1 MS4 permit \\
\hline $\begin{array}{l}\text { 2. System maintenance efforts related to system cleaning, open waterway maintenance, } \\
\text { street sweeping, leaf pick up, and vegetation management }\end{array}$ & Phase 1 MS4 permit \\
\hline Erosion control program & Phase 1MS4 permit \\
\hline 4. Riparian tree planting and vegetation management programs & Phase 1MS4 permit \\
\hline 5. $\quad$ Stormwater development standards & Phase 1MS4 permit \\
\hline 6. $\quad$ Protection of riparian vegetation & Phase 1MS4 permit \\
\hline $\begin{array}{l}\text { 7. Comply with MS4 permit conditions related to TMDLs, including establishing } \\
\text { benchmarks for DO }\end{array}$ & Phase 1MS4 permit \\
\hline 8. Improve channel complexity of Eugene's waterways & $\begin{array}{l}\text { Non-point source/ TMDL / Phase } \\
\text { 1MS4 permit }\end{array}$ \\
\hline $\begin{array}{l}\text { 9. Consider adoption of an ordinance to establish setback buffers by means of a Water } \\
\text { Quality Overlay Zone on waterways with a significant relationship to } 303(\mathrm{~d}) \text { listed } \\
\text { streams, and which are not already protected by some other means (namely Goal 5). }\end{array}$ & Non-point source/ TMDL / Goal 6 \\
\hline 10. Natural resource waterway protections & Goal 5 \\
\hline $\begin{array}{l}\text { 11. Develop TMDL web page, including links to related web sites, the City's TMDL } \\
\text { Implementation Plan, and staff contact information. }\end{array}$ & TMDL \\
\hline
\end{tabular}

Key TMDL implementation plans proposed in the City's 2008 implementation plan include:

1. Implement water quality overlay zones ordinance by June 2009;

2. Annually track implementation of water resource overlay zones;

3. Plant 400 trees per year along south and west side of Amazon Creek; Plant 4,000 linear feet of willow plantings per year along Amazon Creek;

4. Phase 1 MS4 BMPs implementation/activities

a. Provide stormwater education

b. Bacteria Pilot Study

c. Street sweeping and leaf pick-up program

d. Plant 600 trees per year through the Neighborhoods volunteer program

e. On average, plant 5000 linear feet of riparian area each year with native trees and shrubs

\section{Implemented}

The City of Eugene submitted annual TMDL implementation plan reviews from 2009 through 2014. They met or exceeded implementation plan goals annually and overall. Key implementation activities focusing on attainment of bacteria and DO water quality standards included, but were not limited to:

- Waterway protection, restoration, and shading

- Stream Buffers/Riparian Protection

- 35 water quality overlay zone applications from 2009 through 2015

- Enhancing Streamside Shading

- Planted 1,982 trees from 2009 through 2014 (330/year average)

- Did not plant 2013, due to lack of area to plant

- Planted 49,230 willows along 76,849 linear feet

- Did not plant 2013, due to lack of area to plan

\section{- NPDES phase 1 MS4 permit}

- Public Education and Outreach 
- 74,350 to 80,300 Biannual Newsletters (Spring and Fall) recipients

- 2,000 to 3,000 students annually informed on stormwater pollution concerns

- Partnership with veterinarians to inform pet owners of effects of pet waste

- Local News and online-article focusing on pet waste and its effects on water quality

\section{Lane County}

\section{Planned to be Implemented}

Lane County submitted a TMDL Implementation Plan to ODEQ in April 2008. Their Plan focuses on eliminating heat and bacteria through a multi-faceted approach of incentives, land use mechanisms, public operations, partnerships, and education. Lane County has many existing water quality programs, permits, ordinances, and practices which have been implemented and used prior to the 2006 303(d) listing, including their Phase II MS4 permit and others (Table 6) (Lane County, Oregon 2008).

Table 6: Lane County Existing Water Quality Related Program and Policy Inventory (bib, 08lanimpplan)

\begin{tabular}{|l|}
\hline \multicolumn{1}{|c|}{ Existing Programs, Ordinances, and Practices } \\
\hline Roadside vegetation management and last resort herbicide use policy (Lane Code 15.500 to 15.530) \\
\hline Riparian modification standards (Lane Code 16.253) \\
\hline Tree conservation and protection standards (Lane Code 9.90) \\
\hline Floodplain modification standards (Lane Code 16.244 \& 10.271-5-45) \\
\hline Integrated Vegetation Management Program and Vegetation Management Advisory Committee \\
\hline Leaf pick-up program \\
\hline Storm-water maintenance program \\
\hline Lane County Comprehensive Plan Rural Areas [Comprehensive Plan] \\
\hline Lane County Storm-water Management Plan (2004) \\
\hline NPDES Phase II MS4 permit \\
\hline
\end{tabular}

Lane County determined education and training, riparian area protection and management, septic system management, and animal waste management were the highest concerns (Lane County, Oregon 2008). Within Lane County's TMDL Implementation Plan are pledges to increase and/or continue the use of and distribution of prior ordinances, programs, and county codes. These pledges include:

- Increase distribution of educational materials, strengthen relationships with regional watershed councils;

- Planting and recording riparian vegetation (with a minimum of two riparian restoration plantings annually);

- Determine the feasibility of retaining or creating easements for County-owned critical riparian areas proposed for sale as tax foreclosed properties by establishing a framework to review and identify critical riparian areas; and,

- Research opportunities to promote low impact development in parks (Lane County, Oregon 2008).

Implementation of Plan strategies requires a combination of existing funding, future budgeting, and partnerships for grants (Lane County, Oregon 2008). Lane County will continue to seek grant opportunities to address pet waste disposal, riparian restoration and protection, septic sanitation programs, and education of staff, regional landowners, and developers about stormwater management (Lane County, Oregon 2008).

\section{Implemented}

Lane County road maintenance staff have committed 2,517 hours on planning, research, and development of fish-friendly culvert projects incorporating riparian restoration work. No land 
parcels were retained for environmental attributes. A preliminary process has been set up to monitor and evaluate county surplus properties that go to auction, but no parcels with significant riparian attributes have been offered for auction. Pet waste stations are maintained and cleaned daily by County staff. Dog owners are provided informational materials on dog etiquette and pet waste disposal. Lane County distributed 245 brochures entitled "A Homeowner's Guide to Septic System Maintenance", providing relevant information on septic system maintenance. These brochures are distributed when residents contact the department for septic system related applications. County staff presented to local high schools and a community college about stormwater management. Fiscal deficiency is the emphasized reason for the low amount of projects and/or restoration activities.

\section{Oregon Department of Agriculture}

\section{Planned to be Implemented}

ODA's AgWQMP for the Upper Willamette and Upper Siuslaw was designed to prevent and control water pollution from agricultural activities and soil erosion (OAR 603-095-2600(2)). Control measures designed to prevent pollutant loading include: development of riparian vegetation, control of sediment and animal waste runoff, elimination of visual indicators of erosion (sheet erosion, active gullies, multiple rills, etc.), and prevention of contaminant runoff from heavily-used areas (OAR 603-095-2640). Investigation of pollution from any of the above stated prevention and control measures are found through complaints received by ODA from landowners or the public.

Strategies for the plan include educational programs to promote public awareness of water quality issues, partnerships with agribusinesses and agencies to promote water quality, encouragement of agricultural producers to improve water quality, information to landowners to initiate improvements, financial assistance for implementation, funding for technical and/or resource management planning assistance, education, and water quality monitoring, and monitoring to evaluate the effectiveness of the Area Plan and Area Rules (ODA 2007).

The Plan does not regulate. It is guidance for landowners to address water quality issues. In it, they can find contacts for technical and financial assistance that will help them meet their business and conservation goals and attain water quality standards at the same time.

\section{Implemented}

The areas within Amazon and Coyote watersheds managed by ODA do not currently have a focus area. A focus area will be chosen for implementation, with a timeline and objectives made by ODA and SWCD at the 2015 biennial review. District staff distributed 2,000 "Rural and Suburban Living" handbooks. Over 400 landowners have been provided assistance for locating information regarding the Area Plans and Rules. District staff completed 37 site visits with landowners to address water quality concerns associated with agricultural activities on their land. From these visits, 11 small projects were developed, 7 have been completed and 4 were in progress at the time of this project. The majority of these projects involved livestock operations working to address livestock waste concerns, while the other projects addressed riparian area enhancement and irrigation efficiency. District staff provided technical assistance to 37 landowners pertaining to agricultural. District staff worked with 12 landowners to provide planning assistance to implement conservation practices. These plans and practices, funded through OWEB, focused on nutrient management, pasture renovation/rotation, installation of native trees/shrubs in riparian areas, rainwater harvesting for irrigation, and riparian area restoration. Impediments to implementation include, but are not limited to, funding and resources for project implementation, lack of awareness of Area Plans and Rules, landowners lack time to implement projects due to busy farming, communication amongst local partners 
lacked, and communication with landowners conveying their responsibility (voluntary action and regulatory enforcement) and public funds to landowners for projects.

\section{Oregon Department of Forestry}

\section{Planned to be Implemented}

OAR 629-605 requires the operator, landowner, or timber owner to comply with the forest practices statues and rules governing water protection rules (OAR 629-(635:660)) unless approval has been obtained for alternate practices designed to result in the same effect as described in those rules. The overall goal of the water protection rules is to provide protection during forest operations in and around streams, lakes, wetlands, and other riparian areas so that water quality is not impaired. Monitoring of both vegetation and waters shall be conducted on a continual basis to evaluate the effectiveness of the protection rules as well as determine if the FPA goals are being met. Annual reports of monitoring efforts are to be submitted to the Board of Forestry. Rules, regulations, and plans are designed to the stream classification type: Streams that have fish use, including fish use streams that have domestic water use, shall be classified as Type F; Streams that have domestic water use, but not fish use, shall be classified as Type D; and, All other streams shall be classified as Type N (OAR 629-635-0200(4, a:c)). Neither Coyote Creek nor Amazon Creek are used for domestic use yet bot are designated as fish use streams, therefore both are classified as F. The rules are focused upon available tree removal widths from stream and tree and riparian vegetation retention stream side.

ODF is responsible for reviewing pre-operation plans, overseeing operations, ensuring reforestation, investigating complaints, and enforcing corrective actions when violations occur. ODF works with landowners and operators to help them comply with requirements to avoid issuing citations or criminal/civil penalties. Operations requiring notification include road construction, slash disposal, pre-commercial thinning, harvesting, applying chemicals, quarry development, site preparation for reforestation, and changing the use of forestland to non-forest use.

\section{Implemented}

Forest operations in accordance with ODF BMPs are considered to be in compliance with Oregon's water quality standards.

\section{Water Quality Analyses}

Analyses were used to determine if standards were or are currently being met, trends over time, if concentrations increased or decreased with stream flow, if changes had occurred before and after 2008 (TMDL implementation start date), and if implementation activities were influencing concentration levels. Water quality data were obtained from the ODEQ Laboratory Analytical Storage and Retrieval (LASAR) and ELEMENT databases. Available data sets obtained through LASAR and ELEMENT contained data which were either too low $(<)$ or too high $(>)$ for laboratory assessment. Data found to be below or above the minimum or maximum concentration levels were changed to half the amount entered for data entered with $a<$ sign and changed to the amount present for data entered with a > sign; i.e., >2400 was changed to 2400 and $<1$ was changed to 0.5 . Data were visually (graphing or mapping) and quantitatively assessed to examine temporal trends. All statistical testing, modeling, and plot/figure construction were completed using R, version 2.15.0 (R Core Development Team 2016).

Monitoring on Upper Amazon Creek consisted of ten sampling stations, four of which were sampled continuously: Amazon Creek at $29^{\text {th }}$ Avenue, Amazon Creek at the Railroad Crossing; 
Amazon Creek at Royal Avenue, and Willow Creek 180 North of $18^{\text {th }}$ Avenue (Figure 6). Nineteen consecutive years (1997-2015) of data have been collected with an average of six samples collected per year (years and average samples per year collected vary per site). The Amazon Diversion Channel consists of two sampling stations, one of which is continually sampled, Royal Avenue. Royal Avenue has been sampled for 19 consecutive years (19972015) with an average of six samples taken per year (seasonal sampling varies per year). The A-3 Drain consists of five sampling stations, one of which is continually sampled, Terry Street. Terry Street has been sampled for 16 consecutive years (2000-2015) with an average of six samples taken per year (seasonal sampling varies per year). Lower Amazon Creek consists of five sampling stations, two of which were used for analyses. Amazon Creek at High Pass Road was sampled from the winter of 1999 through the summer of 2003 continuously (twice a month on average) and has been sampled on a continual basis from the winter of 2011 to present. Amazon Creek at RM 5.82 was only sampled during mid-summer through early-fall 2015. Amazon Creek at RM 5.82 was chosen because it is halfway between the furthest downstream sampling station in the Upper Amazon (at Royal Avenue) and the furthest downstream sampling station in the Lower Amazon (at High Pass Road). There were ten sampling stations along Coyote Creek, yet few data were available along Coyote Creek. Most stations were sampled one to eight total times. Three stations were sampled continuous (more than twice a month on average) from late summer in 1999 through 2003 at Hamm Road, Powell Road, and at Petzold Road. These three stations were sampled, twice a month, during mid-summer through early-fall 2015 to compare prior trend and current status of E. coli and DO concentration. These stations had the most available data and were located in the headwaters (Hamm Road), the middle of the watershed (Powell Road), and before the confluence of Spencer Creek (Petzold Road). 


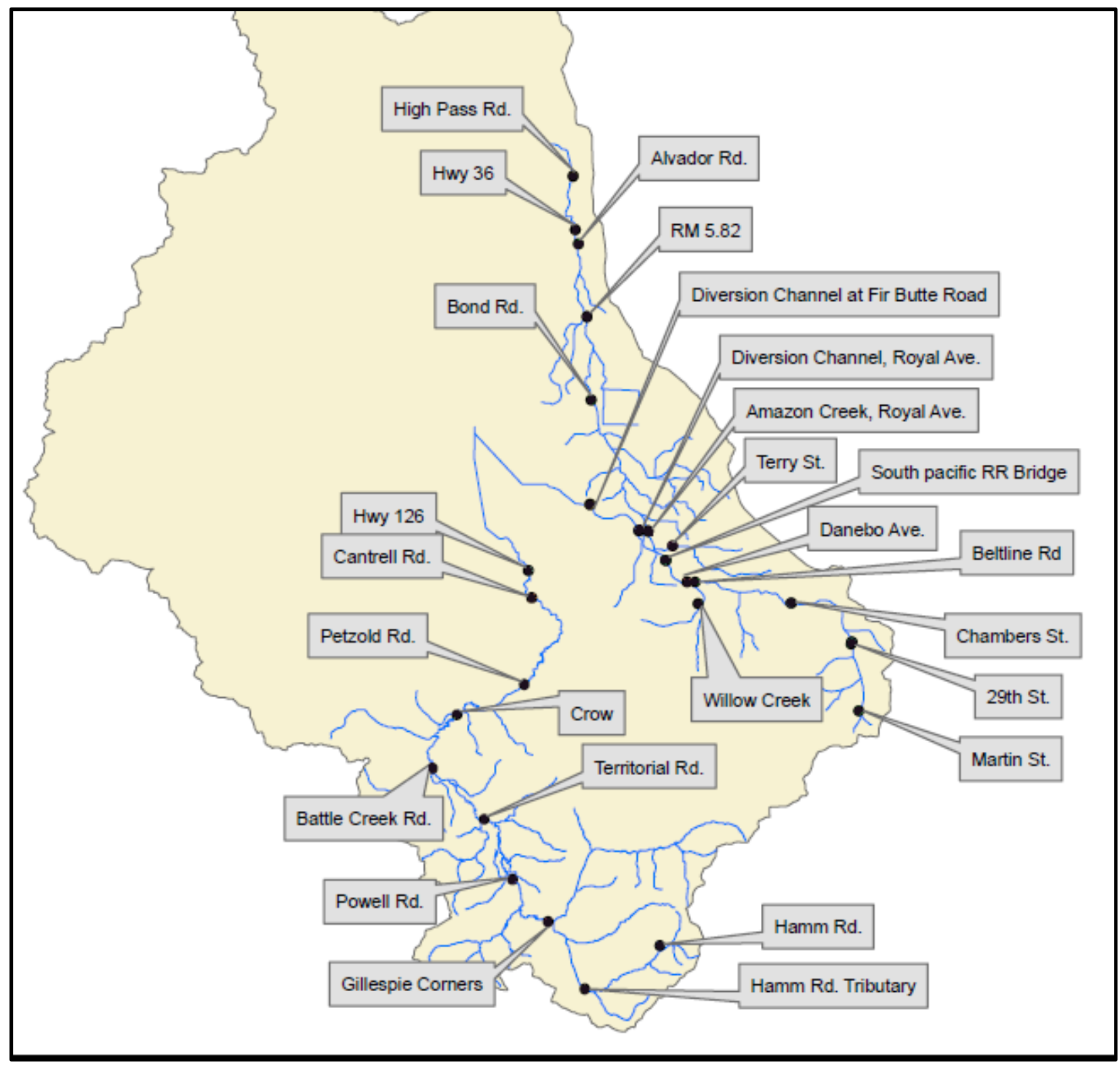

Figure 6. Location of collection stations on Amazon Creek and Coyote Creek

\section{Methods}

\section{Descriptive Statistical Analysis}

Descriptive statistics were used to summarize sample sets through visual analysis prior to analyses of correlations, changes, and trends. A box and whisker plot is a standardized way of displaying the distribution of data, based on the first quartile and third quartile (upper and lower $25^{\text {th }}$ percentile or $25^{\text {th }}$ and $75^{\text {th }}$ percentile), second quartile (median), the whiskers (minimum and maximum), and outliers (greater than 1.5 interquartile ranges away from the $25^{\text {th }}$ and/or $75^{\text {th }}$ percentiles). These plots show the central tendency, range in data, and the skew of the distribution. Box and whisker plots were constructed for annual and seasonal data. These data sets were split into before and after 2008. Exceedance percentages of each collection station, both overall and seasonally, before and after 2008 was built to display increasing, decreasing, or no change in the single sample exceedance criterion. Both box and whisker plots and 
percentages of exceedances were not used for statistical analyses. They were used only to examine data distributions for statisitcal testing procedures.

\section{Testing for Dependence}

To test whether the occurrence of single sample exceedances were seasonally dependent, a Fischer's exact test was applied. A Fischer's exact test is similar to a Chi-square test, testing whether observed distribution is due to random chance. The Fischer's exact test is used when sample size is small to avoid approximation of a $p$-value. To perform the Fischer's exact test, contingency tables were designed based on exceedances of single sample criterion and nonexceedance of State single sample criterion of both E. coli and DO before and after 2008. The contingent parameters were seasonal (winter, spring, summer, and fall). The null hypothesis was that exceedance of single sample criterion was seasonally independent. The null hypothesis was rejected, and found to be dependent, with a $p$-value $<0.10$.

\section{Testing for Change in Means Before and After 2008}

To determine if TMDL implementation activities after 2008 had possible influences to bacteria and DO concentrations, Wilcoxon rank-sum tests were used. The Wilcoxon rank-sum test is a non-parametric alternative to the Student's t-sest used for examing the differences in observations to assess whether their population means differ. The Wilcoxon rank-sum test is used when populations cannot be assumed to be normally distributed and also allows for unpaired and/or independent data sets. The null hypothesis for Wilcoxon rank-sum test is that concentration means before and after 2008 are the same. The null hypothesis was rejected, if the $p$-value was $<0.10$.

\section{Testing forTrends and Changes in Trends Before and After 2008}

I used linear regression analysis to examine data trends before and after 2008, both seasonally and for the entire data set. E. coli datasets were log transformed to meet assumptions of normality. Adjusted $\mathrm{R}^{2}$ values and $p$-values were used to assess linear trends. Linear models were deemed statistically significant if the $p$-value was $<0.10$. A Chow test was used to determine if linear regression models before and after 2008 were different. A Chow test determines whether the slopes and intercepts of the linear regression of one group are different from those of another group by using the error sum of squares from separate regressions, error sum of squares from the pooled regression, the number of parameters, and the number of observations in each groups. Rejection of the null hypothesis $(p$-value $<0.10)$ will conclude there was a significant difference in models before and after 2008.

\section{Forecasting $E$. coli and DO Concentration}

In order to forecast future E. coli and DO concentration levels, ARIMA models where developed. ARIMA modeling is a technique that projects future values of a series based on previous values. ARIMA stands for Autoregressive-Integrated-Moving Average; "AR" extracts the influence of the previous periods' values on the current period, "l" subtracts the time series with its lagged series to extract trends from the data making the data stationary (log transformation will be used to create stationary data), and "MA" extracts the influence of the previous periods' error terms on the current periods' error. An ARIMA model's main application is short-term forecasting of $>40$ historical data points, and works best when data exhibit a stable or consistent pattern over time with minimal outliers (Hyndman and Athanasopoulos 2016). Auto ARIMA modeling was used as a function, which automates the ARIMA modeling procedure to identify the best fit ARIMA model. Five-year forecasts of collection stations were used to determine short-term trends in bacteria and DO levels.

\section{Results}




\section{Bacteria}

\section{Upper Amazon}

\section{Amazon Creek at $29^{\text {th }}$ Avenue}

Amazon Creek at $29^{\text {th }}$ Avenue exceeds single sample criterion for $E$. coli year-round, both before and after 2008 (Figure 1, Appendix A: Figure 1, Table 1). The change in the percentage of single sample exceedance before and after 2008 decreased $20 \%$ during the spring, yet increased by $15 \%$ and $21 \%$ during the summer and fall, respectively. Overall, the percentage of exceedances before and after 2008 increased by 6\%. The geometric means during all seasons, both before and after 2008, exceeded State single sample criterion. Based on these data, the allocated percent reduction in bacterial concentration (84\%) has not been met since TMDL implementation. E. coli concentrations have increased by $4 \%$, on average.

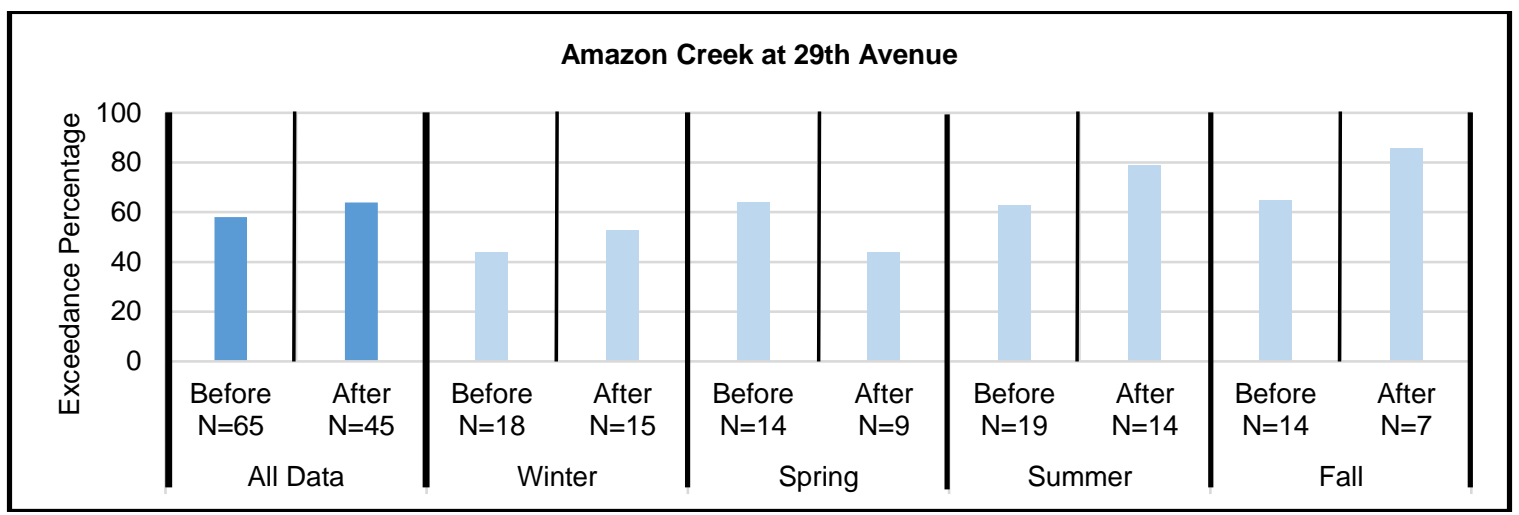

Figure 1: Bar charts of the percentage of single sample E. coli criterion exceedance before and after 2008 on Amazon Creek at $29^{\text {th }}$ Avenue. The charts are split seasonally, as well as all data.

Frequency of single sample exceedance criterion at $29^{\text {th }}$ Avenue was not seasonally dependent before or after 2008 (Appendix B: Table 1 and 2). There were no significant changes found for the means before and after 2008 for any data set (Appendix C: Table 1). The spring before 2008 was the only data set found to have a significant linear trend (decreasing) (Figure 2, Appendix D: Table 1). There were no significant changes found in the slopes before and after 2008 in any data set. The high variability of each sample collection, along with minimal seasonal/yearly data collection caused uncertainty in the ability to forecast $E$. coli concentration through ARIMA modeling. The model forecasted a mean near the present median (490 E.coli organisms (MPN)/100 ml) and the 95\% confidence interval is well above the State single sample criterion (Appendix E: Figure 1).

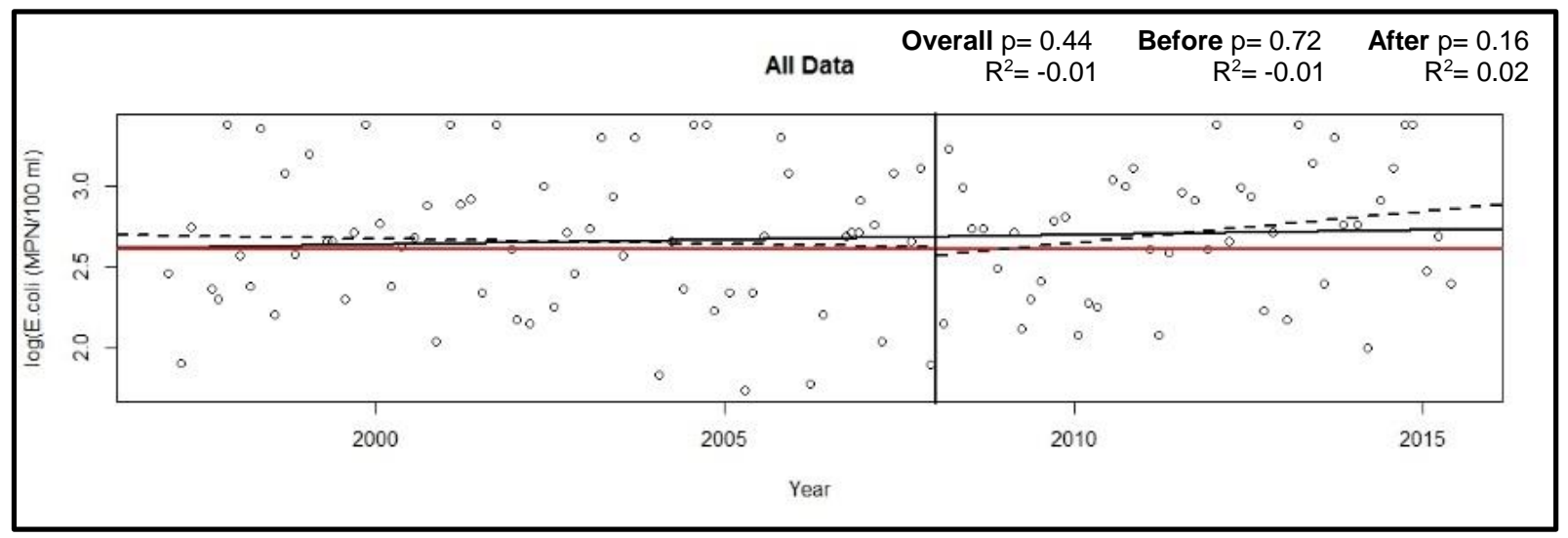




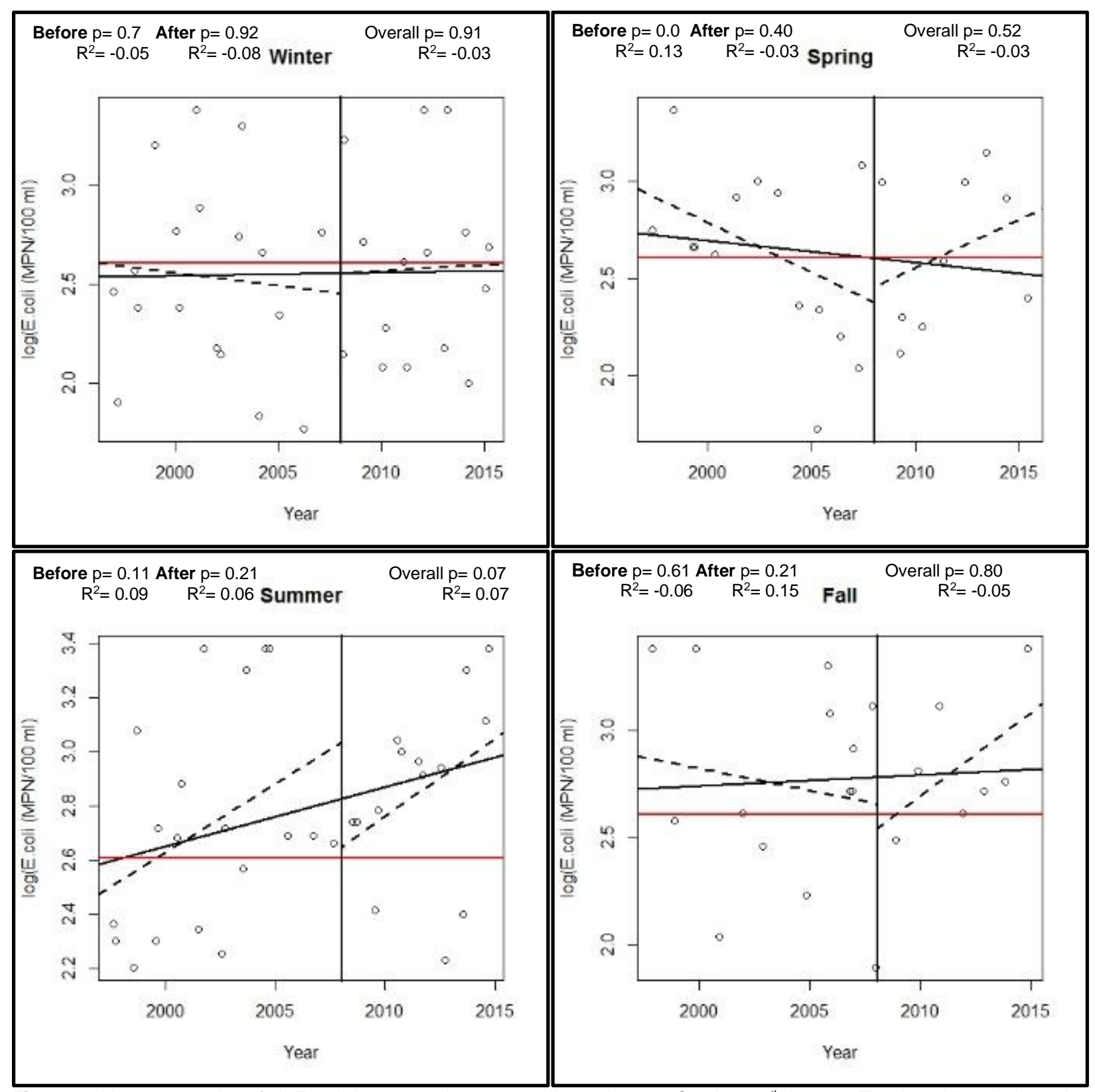

Figure 2: Linear regression of all E. coli data, as well as seasonally, on Amazon Creek at $29^{\text {th }}$ Avenue. The dotted lines indicated linear regression before and/or after 2008. The solid black line indicates the overall linear regression. The horizontal red line is the State single sample exceedance level (406 E. coli organisms (MPN)/100 ml).

\section{Amazon Creek at Railroad Crossing}

Amazon Creek at Railroad Crossing exceeds State single sample criterion for $E$. coli yearround, both before and after 2008 (Figure 3, Appendix A: Figure 2, Table 2). Single sample exceedances during the spring decreased by $38 \%$; in summer, exceedances increased by $28 \%$. Overall, the exceedances increased by $10 \%$ after 2008. The geometric mean after 2008 was above the single sample criterion. The allocated percent reduction in bacterial concentration $(84 \%)$ has not been met since 2008 . E. coli concentrations have increased by $11 \%$, on average. 


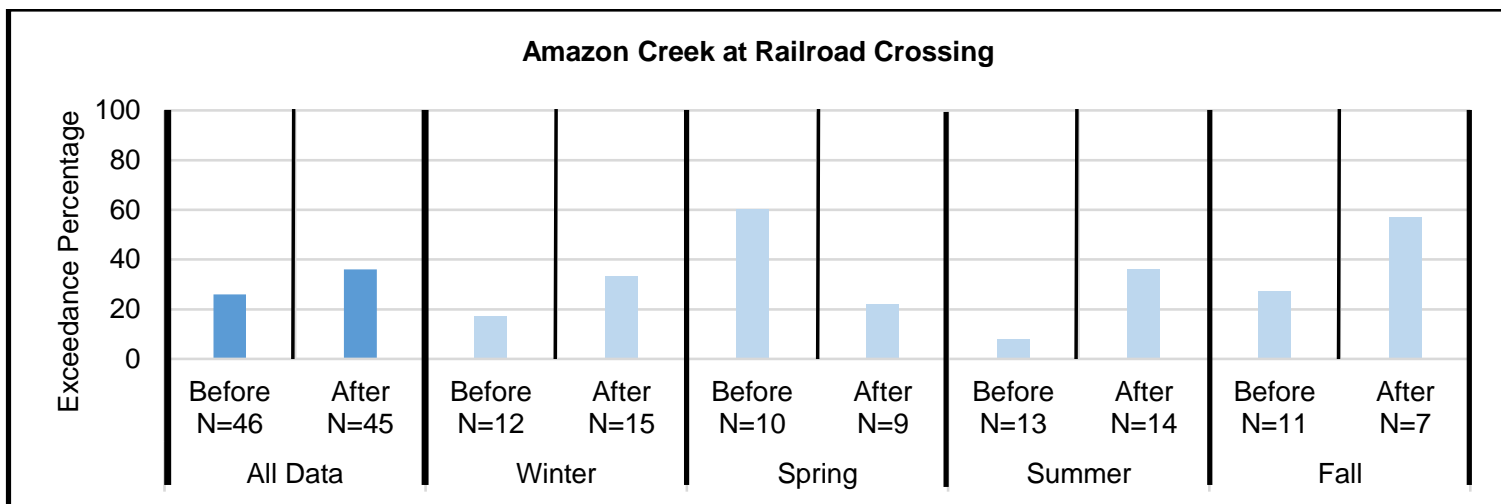

Figure 3: Bar charts of the percentage of single sample E. coli criterion exceedance before and after 2008 on Amazon Creek at Railroad Crossing. The charts are split seasonally, as well as all data.

Single sample exceedance criterion at Railroad Crossing was significantly seasonally dependent before but not after 2008 (Appendix B: Table 1 and 2). There were no significant changes in the means before and after 2008 for any dataset (Appendix C: Table 2). There were no significant linear trends for any dataset (Figure 4, Appendix D: Table 2). There were no significant differences in the slopes before and after 2008 for any dataset. The high variability of samples along with minimal seasonal/yearly data collection caused uncertainty in forecasting $E$. coli concentrations with ARIMA modeling. The model forecasted a mean below the single sample criterion, yet the upper 95\% confidence interval falls above single sample criterion (Appendix E: Figure 2).

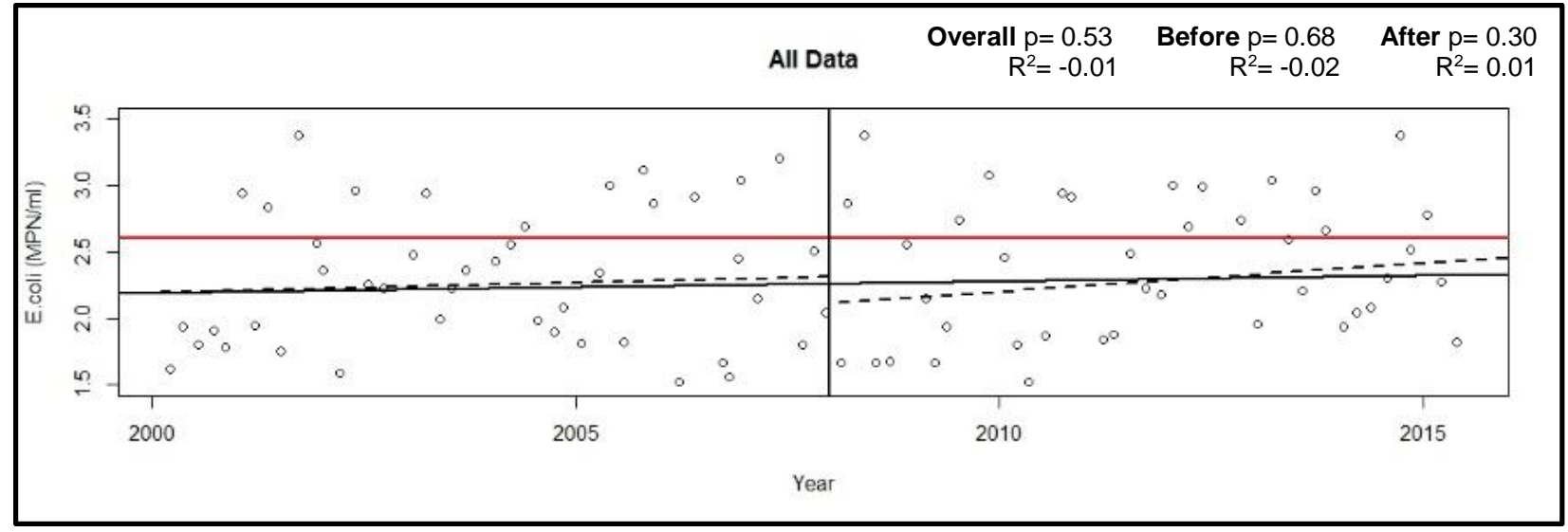




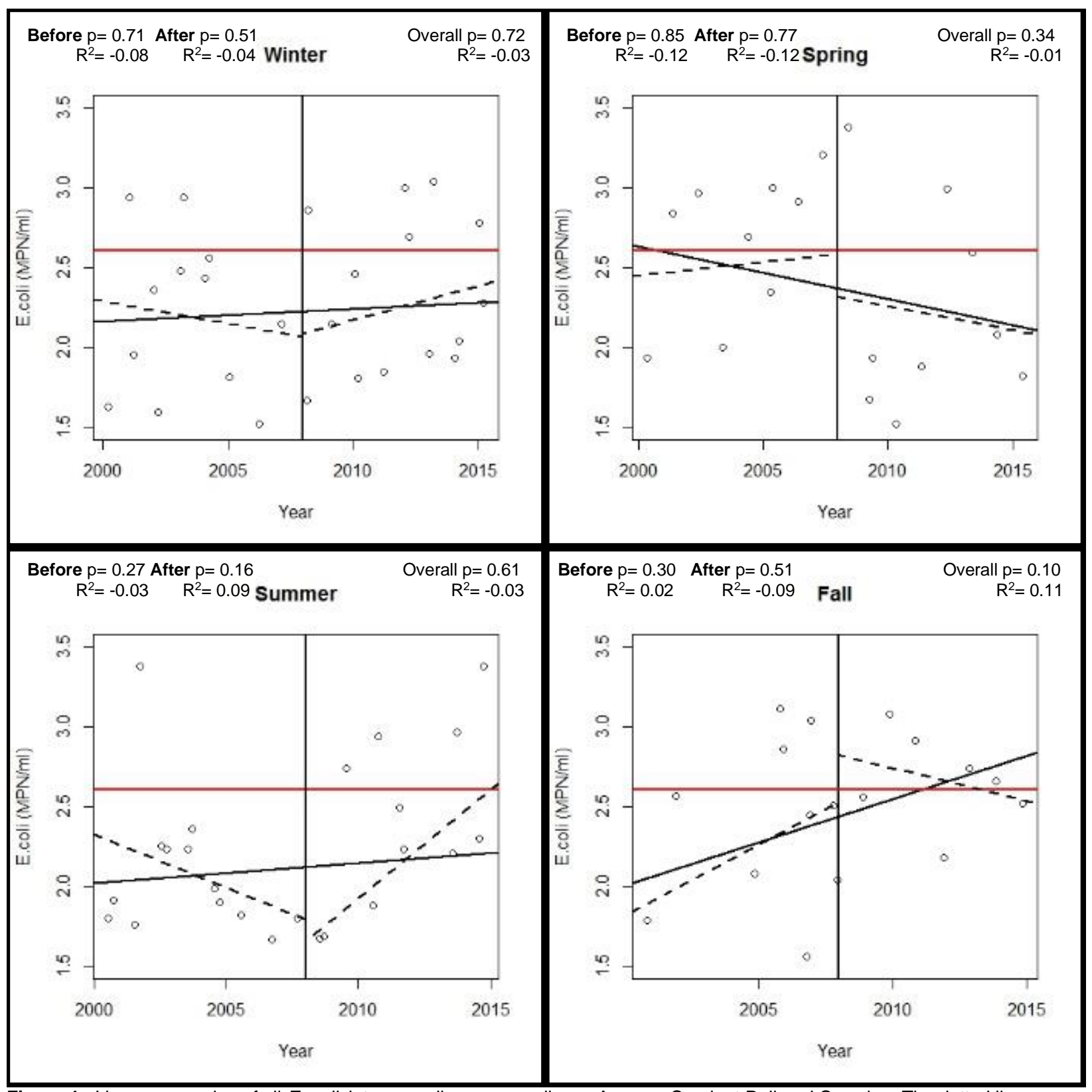

Figure 4: Linear regression of all E. coli data, as well as seasonally, on Amazon Creek at Railroad Crossing. The dotted lines indicated linear regression before and/or after 2008. The solid black line indicates the overall linear regression. The horizontal red line is the State single sample exceedance level (406 E. coli organisms (MPN)/100 ml).

\section{Amazon Creek at Royal Avenue}

Amazon Creek at Royal Avenue exceeds single sample criterion for $E$. coli year round before and after 2008 (Figure 5, Appendix A: Figure 3, Table 3). Single sample exceedances increased during the winter by $29 \%$, decreased during the summer by $35 \%$, and decreased overall by $7 \%$. The allocated percent reduction in bacterial concentration (84\%) has not been met since 2008. E. coli concentrations have decreased by $9 \%$, on average. 


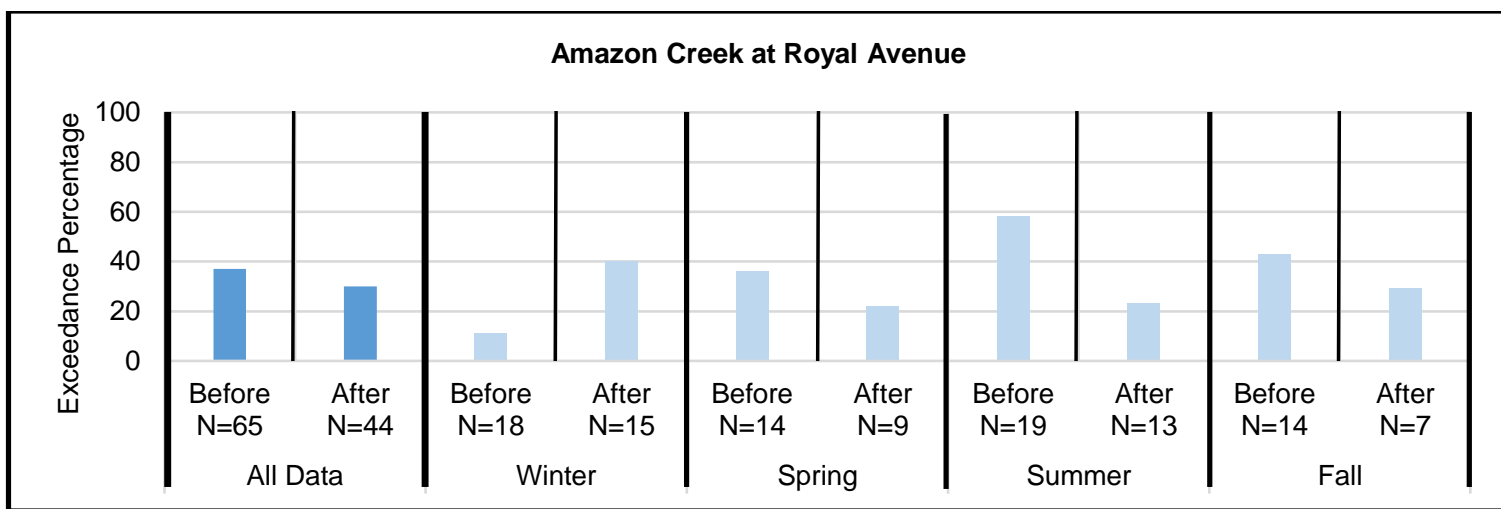

Figure 5: Bar charts of the percentage of single sample E. coli criterion exceedance before and after 2008 on Amazon Creek at Royal Avenue. The charts are split seasonally, as well as all data.

Single sample exceedances at Royal Avenue were significantly seasonally dependent before but not after 2008 (Appendix B: Table 1 and 2). The means during the summer, before and after 2008, were the only datasets found to have significant differences (Appendix C: Table 3). Linear regression analysis found no significant trends for any of the datasets (Figure 6, Appendix D: Table 3). There were no significant differences in the slopes before and after 2008 in any data set. The high variability of each sample collection, paired with minimal seasonal/yearly data collection led to uncertain forecasts of $E$. coli concentrations through ARIMA modeling. The model forecasted a mean below single sample criterion, yet the upper $95 \%$ confidence interval was above single sample criterion (Appendix E: Figure 3).

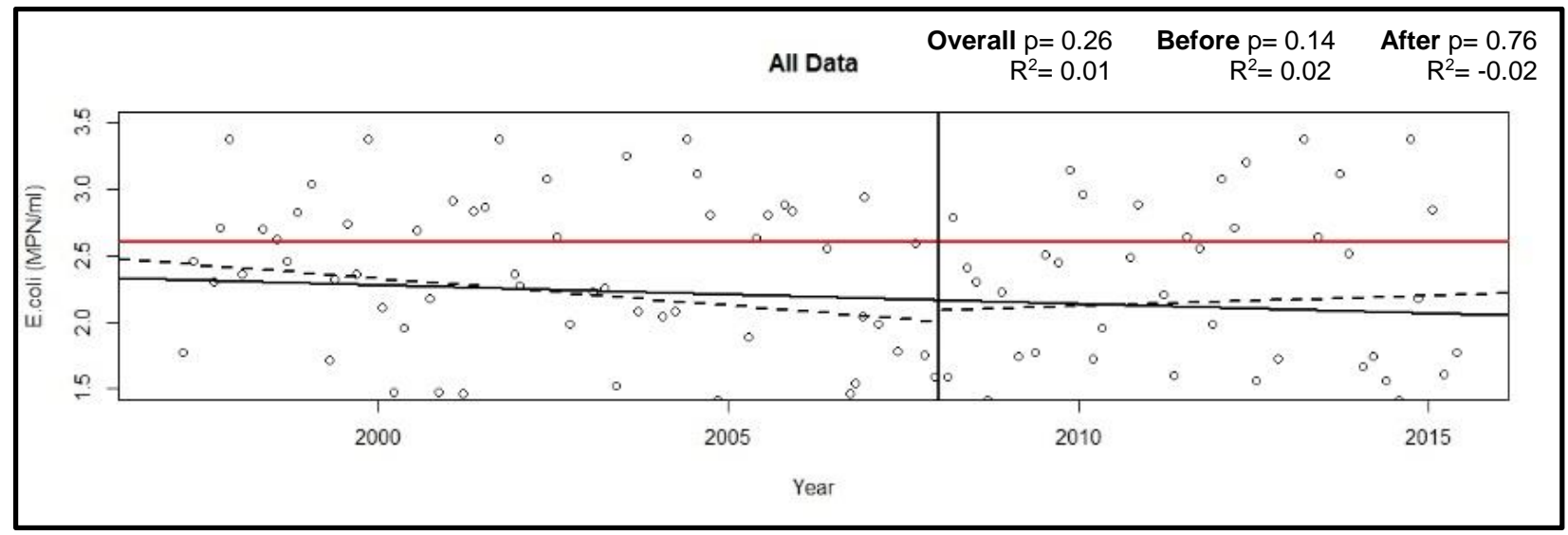




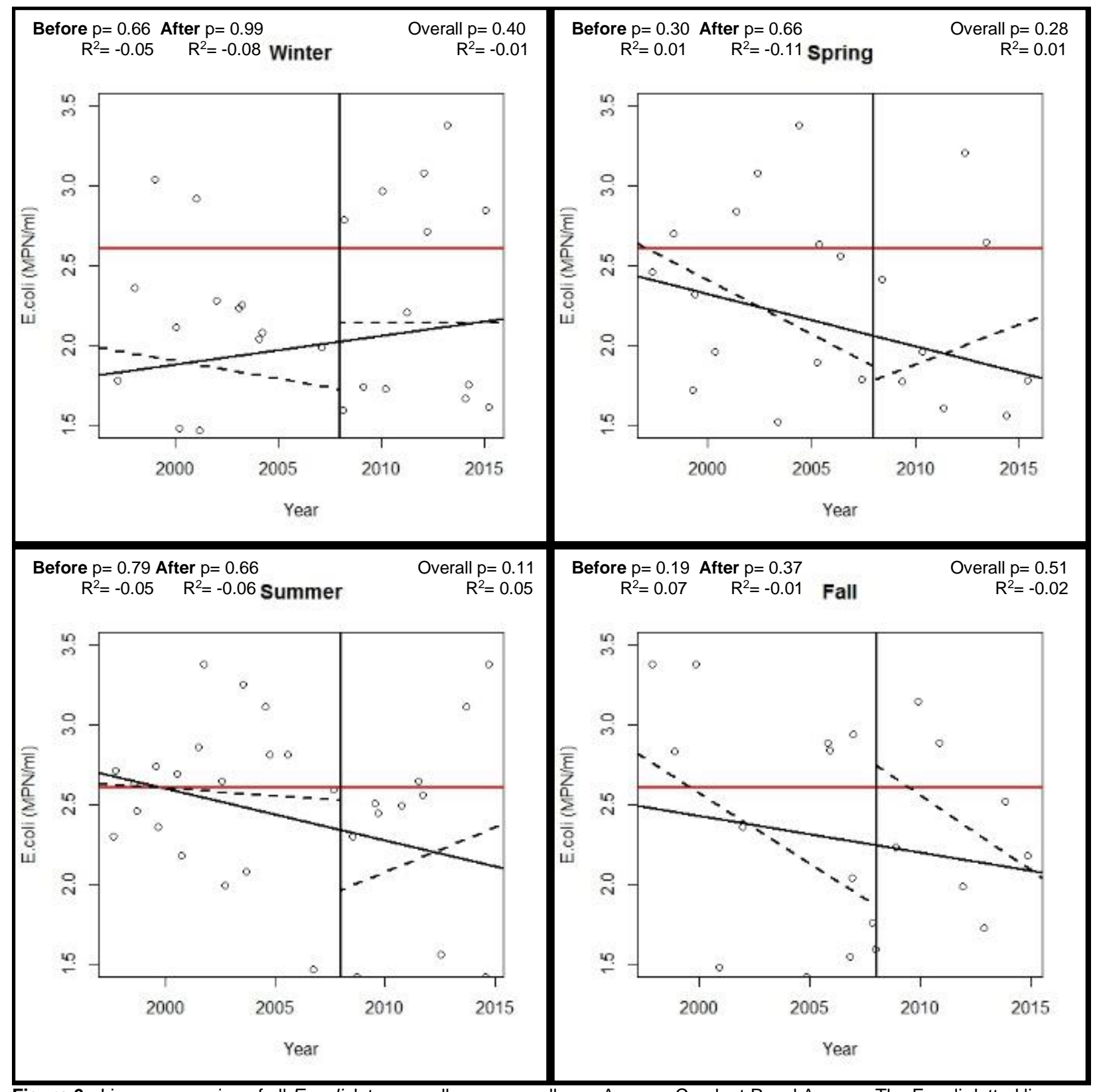

Figure 6: Linear regression of all E. coli data, as well as seasonally, on Amazon Creek at Royal Avenue. The E. coli dotted lines indicated linear regression before and/or after 2008. The solid black line indicates the overall linear regression. The horizontal red line is the State single sample exceedance level (406 E. coli organisms (MPN)/100 ml).

\section{Willow Creek at 18th Avenue}

Willow Creek at 18th Avenue exceeds single sample criterion for E. coli year-round, both before and after 2008, except for the winter before 2008 (Figure 7, Appendix A: Figure 4, Table 4). The winter before 2008 had did not exceed single sample criterion. The highest percentage of exceedances occurred in the summer after 2008 (50\%), although the summer after 2008 was only sampled twice. Exceedances increased by $7 \%$. The geometric means and the first and third quartiles during the all seasons, other than the summer after 2008, were below single sample criterion. The allocated percent reduction in bacterial concentration (84\%) has not been met. E. coli concentrations have increased by $62 \%$, on average. 


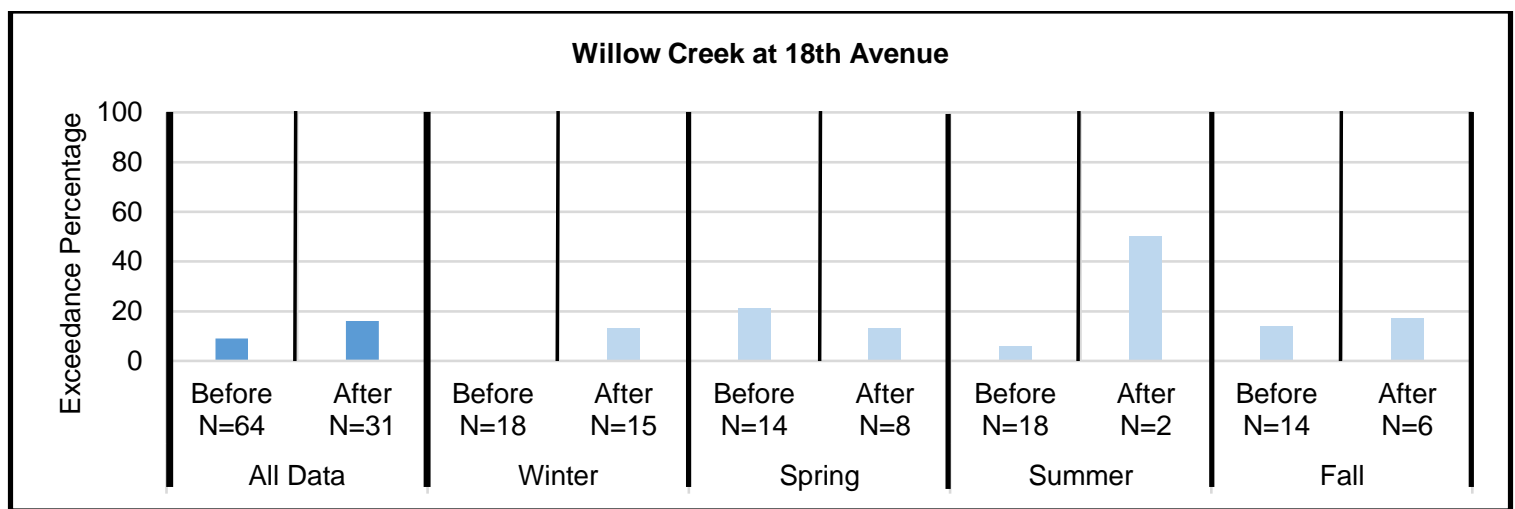

Figure 7: Bar charts of the percentage of single sample E. coli criterion exceedance before and after 2008 on Willow Creek at $18^{\text {th }}$ Avenue. The charts are split seasonally, as well as all data.

Single sample exceedance criterion at on Willow Creek at $18^{\text {th }}$ Avenue was not found to be seasonally dependent found before or after 2008 (Appendix B: Table 1 and 2). There were no significant changes found for the means before and after 2008 for any data set (Appendix C: Table 4). The spring before 2008 was the only data set to have a significant decreasing linear trend (Figure 8, Appendix D: Table 4). The lack of seasonal/yearly data did not permit auto ARIMA modeling.

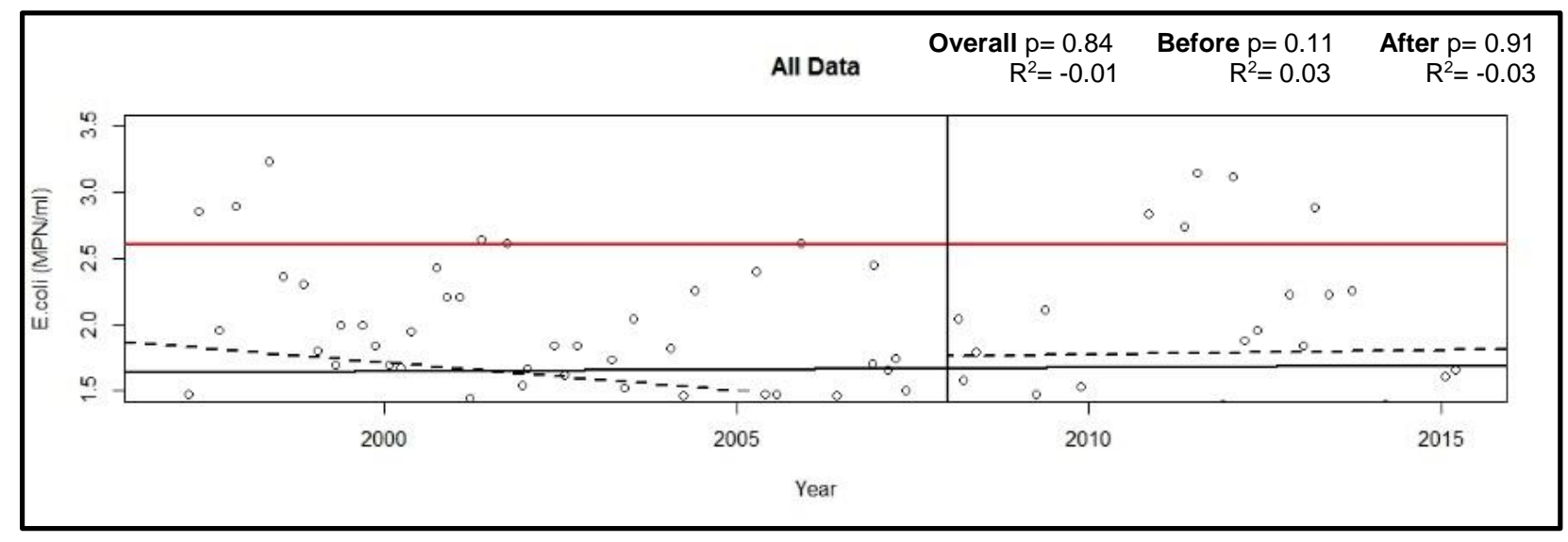




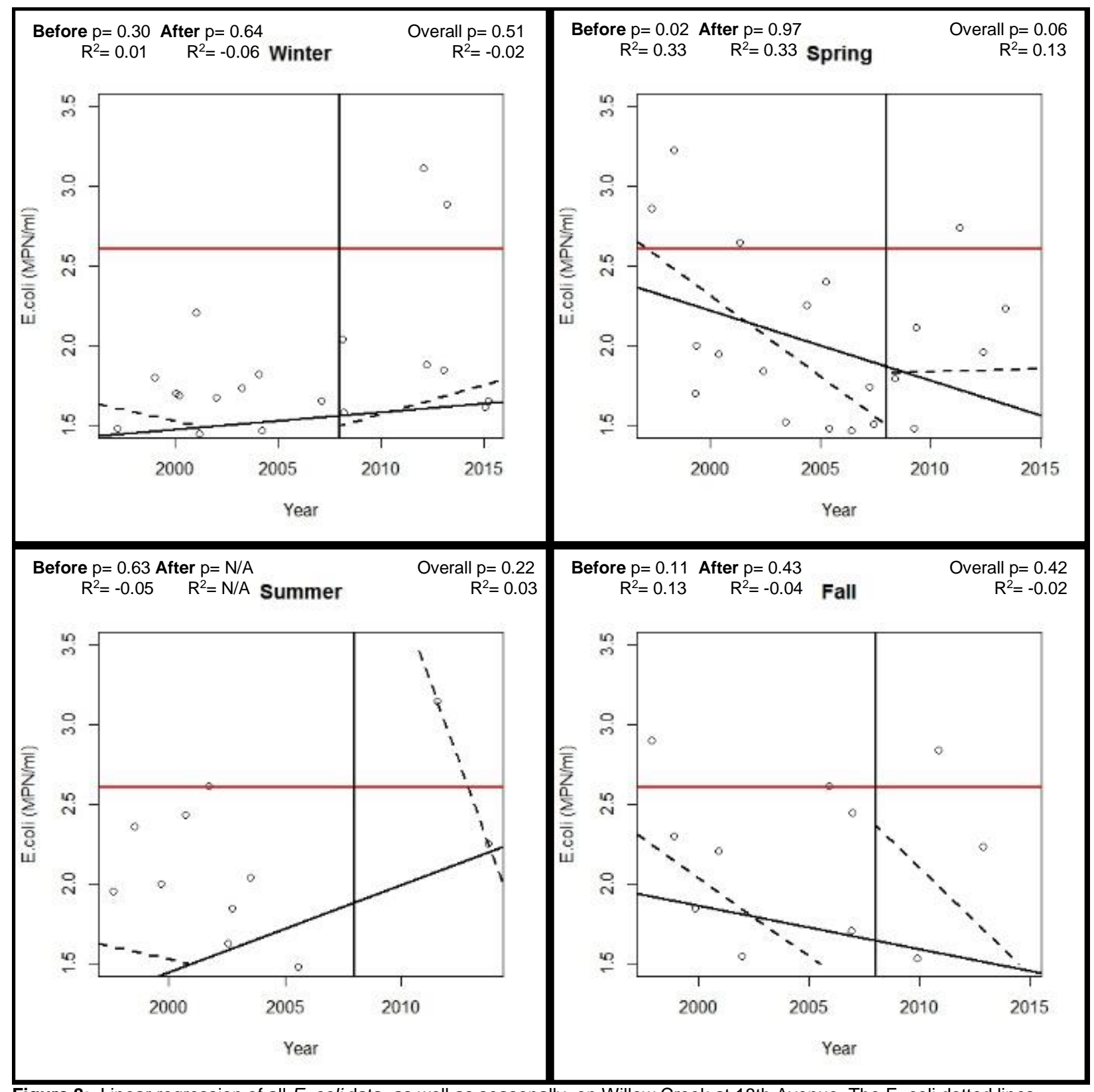

Figure 8: Linear regression of all E. coli data, as well as seasonally, on Willow Creek at 18th Avenue. The E. coli dotted lines indicated linear regression before and/or after 2008. The solid black line indicates the overall linear regression. The horizontal red line is the State single sample exceedance level (406 E. coli organisms (MPN)/100 ml).

\section{Amazon Diversion Channel at Royal Avenue}

Amazon Diversion Channel at Royal Avenue exceeded single sample criterion for $E$. coli yearround, both before and after 2008, except for the spring after 2008 (Figure 9, Appendix A: Figure 5, Table 5). The highest percentage of exceedances was the summer before 2008 (58\%), although the summer after 2008 decreased $31 \%$. Exceedance percentage also decreased $15 \%$ during the spring after 2008 . The overall exceedance percentage decreased by $10 \%$. The geometric mean was above single sample criterion during the summer before 2008 , yet decreased to just under single sample criterion after 2008. The allocated percent reduction in bacterial concentration (84\%) has not been met since 2008. E. coli concentrations have decreased by $27 \%$, on average. 


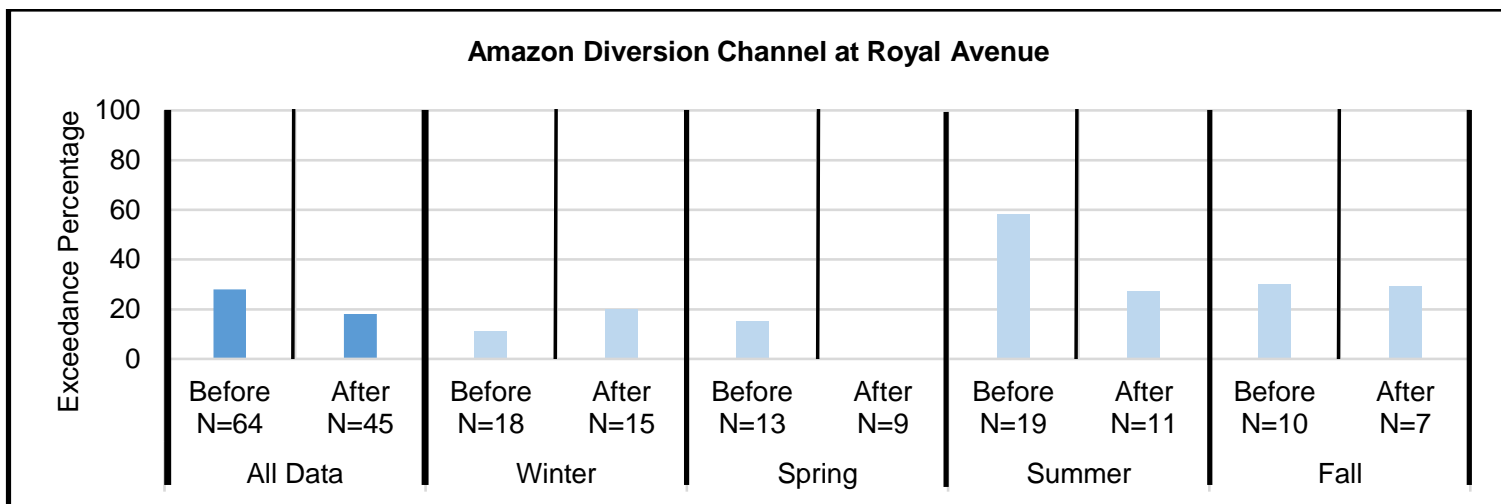

Figure 9: Bar charts of the percentage of single sample E. coli criterion exceedance before and after 2008 on Amazon Diversion Channel at Royal Avenue. The charts are split seasonally, as well as all data.

Single sample exceedance criterion on the Amazon Diversion Channel at Royal Avenue was found to be significantly seasonally dependent before 2008 only (Appendix B: Table 1 and 2). E. coli concentrations in the summers before and after 2008 were the only seasonal datasets found to be significantly different (Appendix C: Table 5). Linear regression analysis found the overall data set after 2008 to be the only data set to have a significant trend (decreasing) (Figure 10, Appendix D: Table 5). Summers were significantly different in trends before and after 2008. The slope before 2008 was decreasing and the slope after 2008 had an increasing trend. The high variability of samples along with minimal seasonal/yearly data collection caused uncertain forecasts of $E$. coli concentrations via ARIMA modeling. The model forecasted a mean below the single sample criterion, yet the upper 95\% confidence interval was above the single sample criterion (Appendix E: Figure 4).

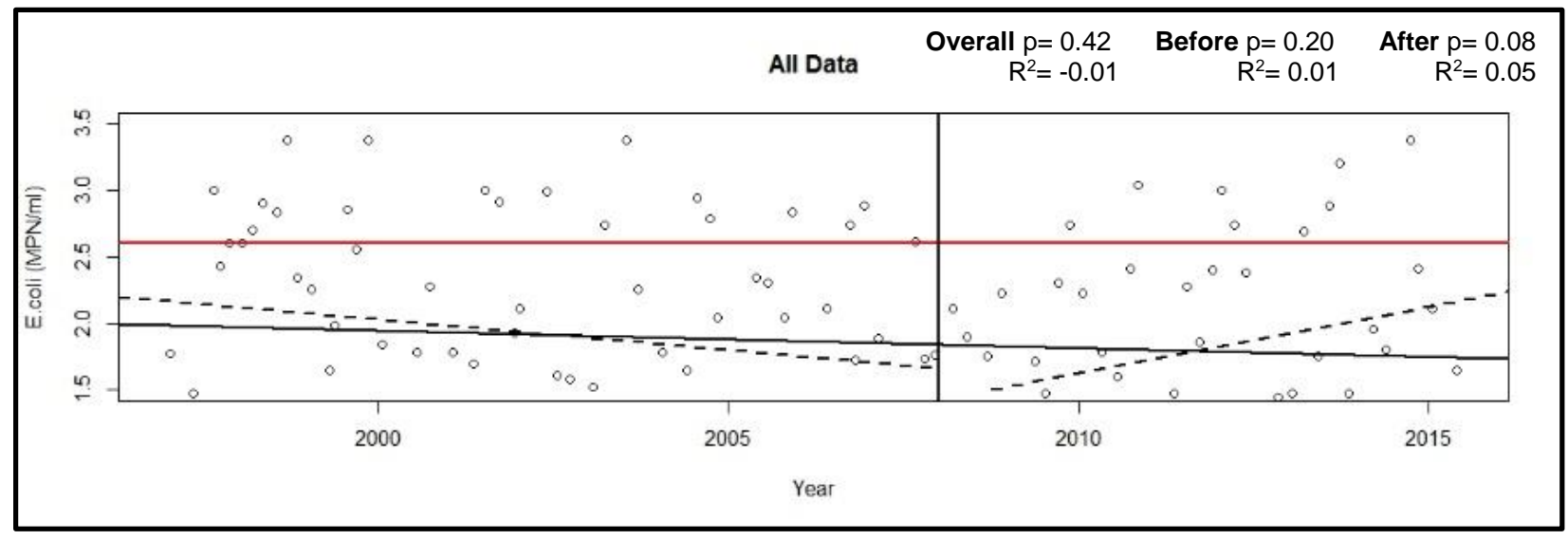




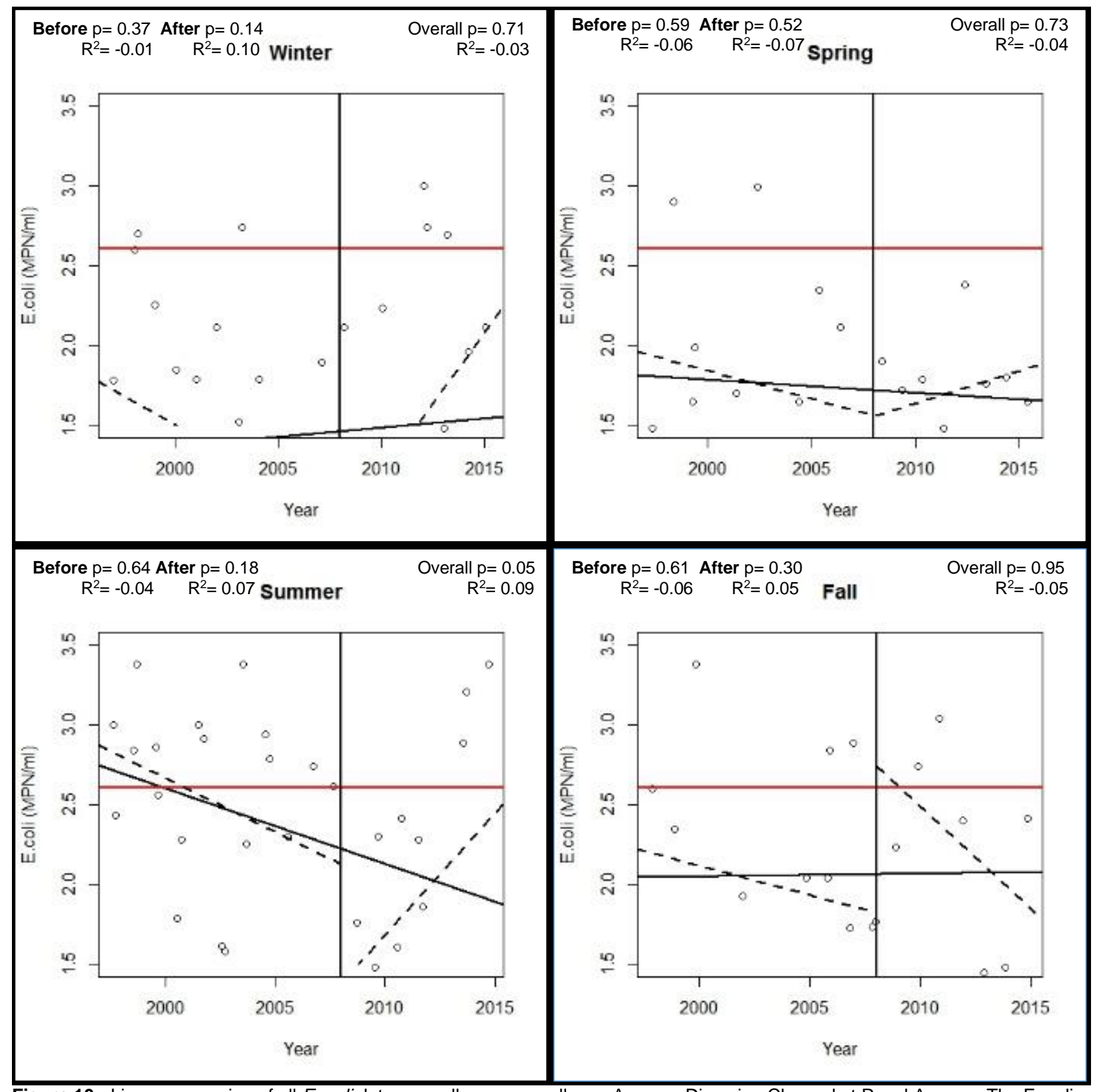

Figure 10: Linear regression of all E. coli data, as well as seasonally, on Amazon Diversion Channel at Royal Avenue. The E. coli dotted lines indicated linear regression before and/or after 2008. The solid black line indicates the overall linear regression. The horizontal red line is the State single sample exceedance level (406 E. coli organisms (MPN)/100 ml).

\section{A-3 Drain at Terry Street}

A-3 Drain at Terry Street exceeded State single sample criterion for E. coli year-round, both before and after 2008 (Figure 11, Appendix A: Figure 6, Table 6). The highest percentage of exceedances was during the summer both before (62\%) and after (67\%) 2008. Exceedance percentage decreased during the spring by $45 \%$ after 2008 . The overall exceedance percentage decreased by $11 \%$. The allocated percent reduction in bacterial concentration (33\%) has been met since 2008. E. coli concentrations have decreased by $48 \%$, on average. However, the exceedance percentage of the 40 samples was $28 \%$. 


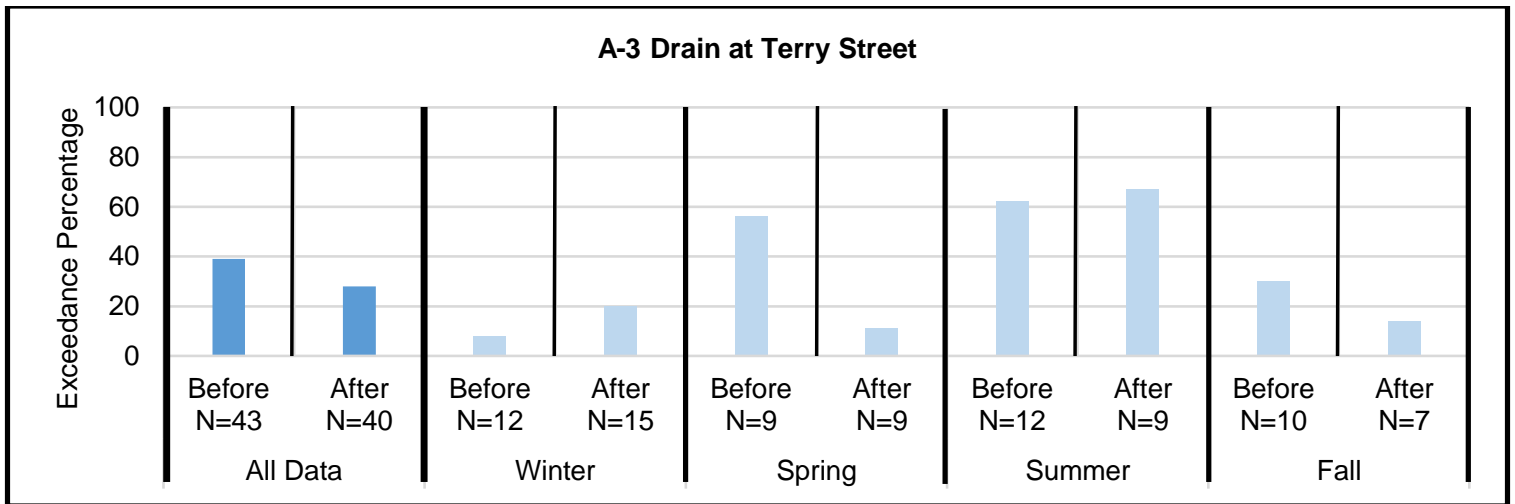

Figure 11: Bar charts of the percentage of single sample E. coli criterion exceedance before and after 2008 on A-3 Drain at Terry Street. The charts are split seasonally, as well as all data.

Single sample exceedances in the A-3 Drain were significantly seasonally dependent (Appendix $\mathrm{B}$ : Table 1 and 2). There were no significant differences in the means before and after 2008 for any dataset (Appendix C: Table 6). There were no significant linear trends for any dataset (Figure 12, Appendix D: Table 6). There were no significant differences in the slopes before and after 2008 for any dataset. The high variability among samples along with minimal seasonal/yearly data collection caused uncertain forecasts of $E$. coli concentrations via ARIMA modeling. The model forecasted a mean concentration below single sample criterion. However, the forecasted, upper 95\% confidence interval for mean concentration was above the single sample criterion (Appendix E: Figure 5).

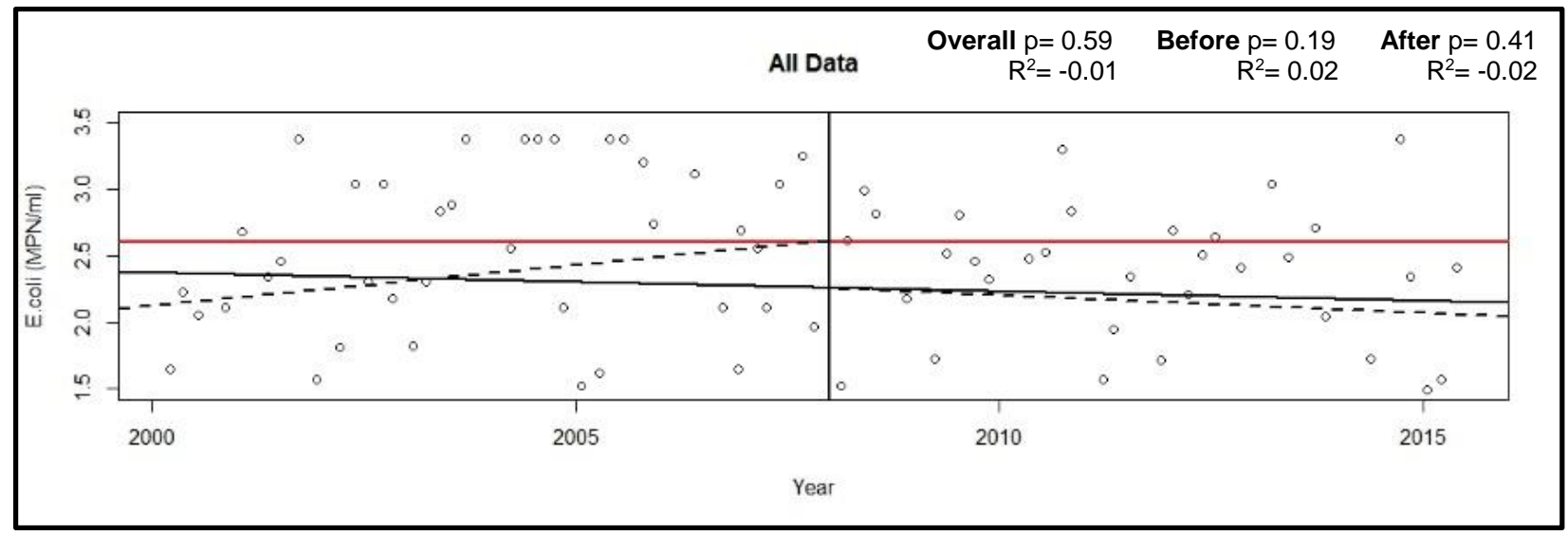




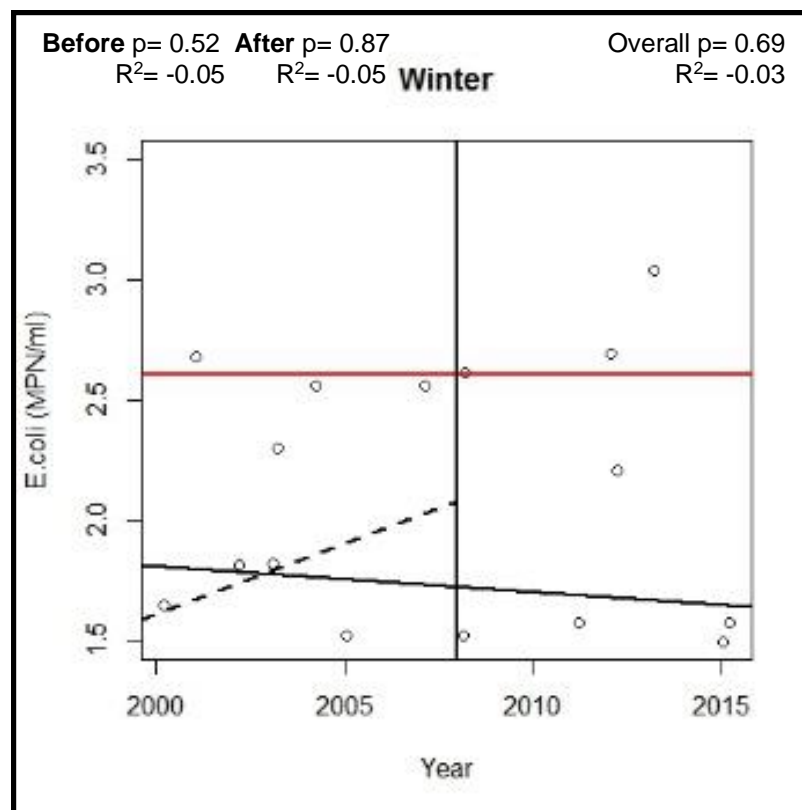

Before $\mathrm{p}=0.11$ After $\mathrm{p}=0.40$ $R^{2}=0.15 \quad R^{2}=-0.03$ summer

Overall $p=0.41$ $R^{2}=-0.01$

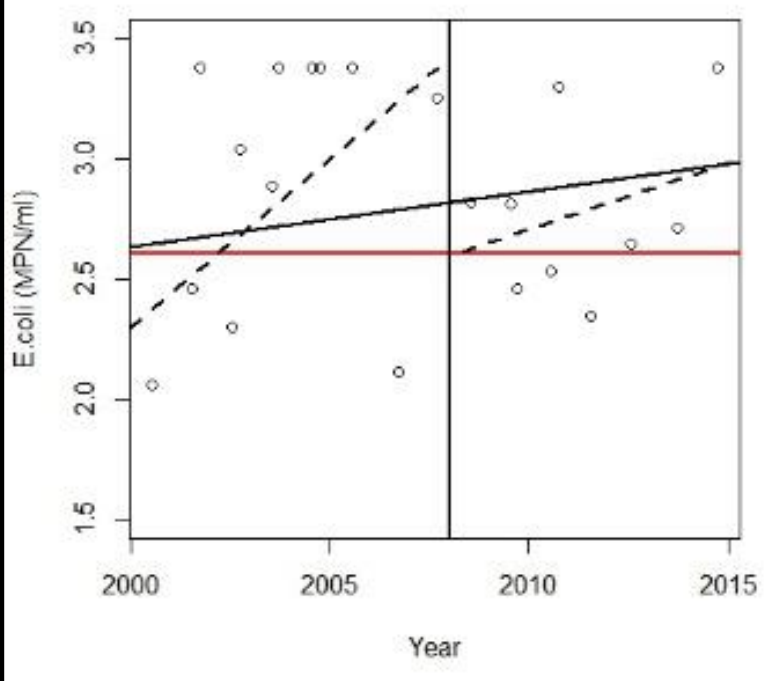

Before $\mathrm{p}=0.83$ After $\mathrm{p}=0.83$

$R^{2}=-0.14 \quad R^{2}=-0.07$ spring

Overall $p=0.19$

$\mathrm{R}^{2}=0.05$

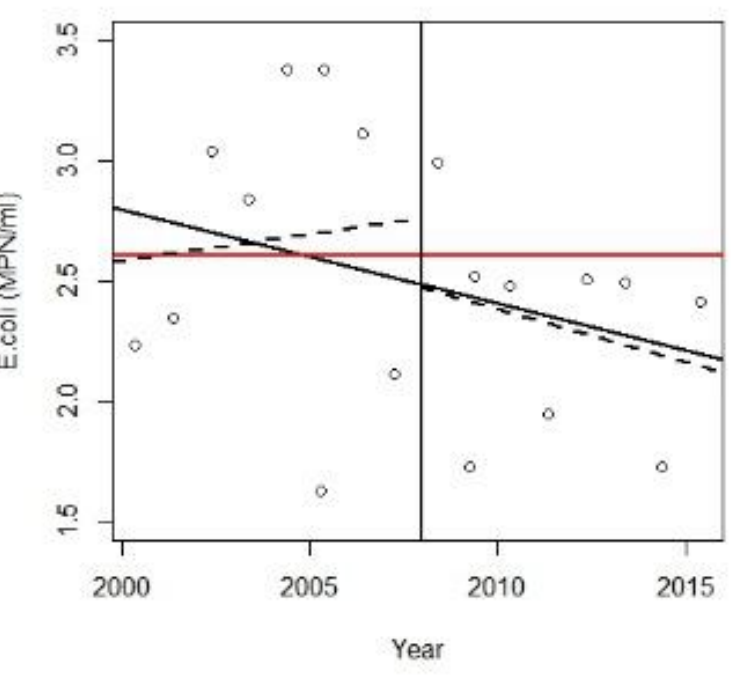

Before $\mathrm{p}=0.91$ After $\mathrm{p}=0.80$

$R^{2}=-0.12 \quad R^{2}=-0.18 \quad$ Fall

Overall $p=0.73$

$R^{2}=-0.06$

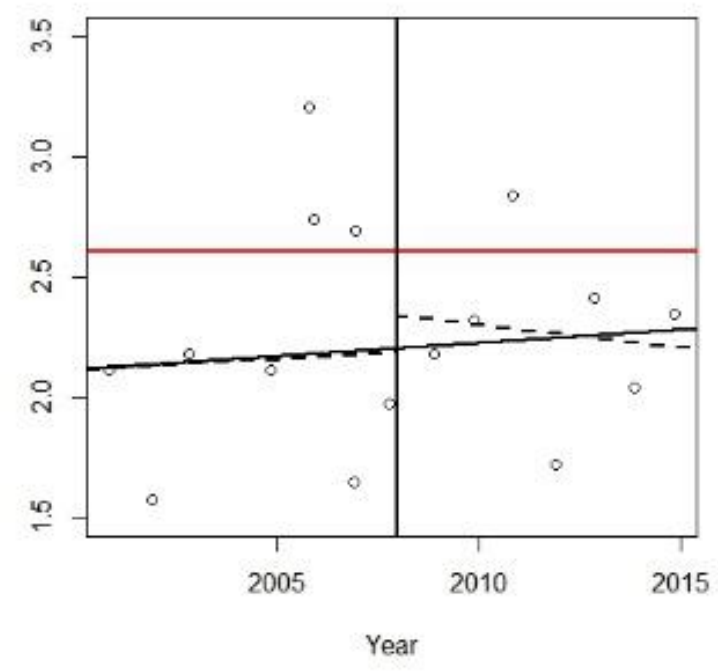

Figure 12: Linear regression of all E. coli data, as well as seasonally, on A-3 Drain at Terry Street. The E. coli dotted lines indicated linear regression before and/or after 2008. The solid black line indicates the overall linear regression. The horizontal red line is the State single sample exceedance level (406 E. coli organisms (MPN)/100 ml).

\section{Lower Amazon}

\section{Amazon Creek at RM 5.82}

Amazon Creek at RM 5.82 was not sampled before 2008, but it exceeded the single sample criterion for E. coli in summer 2015 (Figure 13, Appendix A: Figure 7, Table 7). The allocated percent reduction in bacterial concentration (58\%) could not be assessed due to lack of data prior to 2008. 


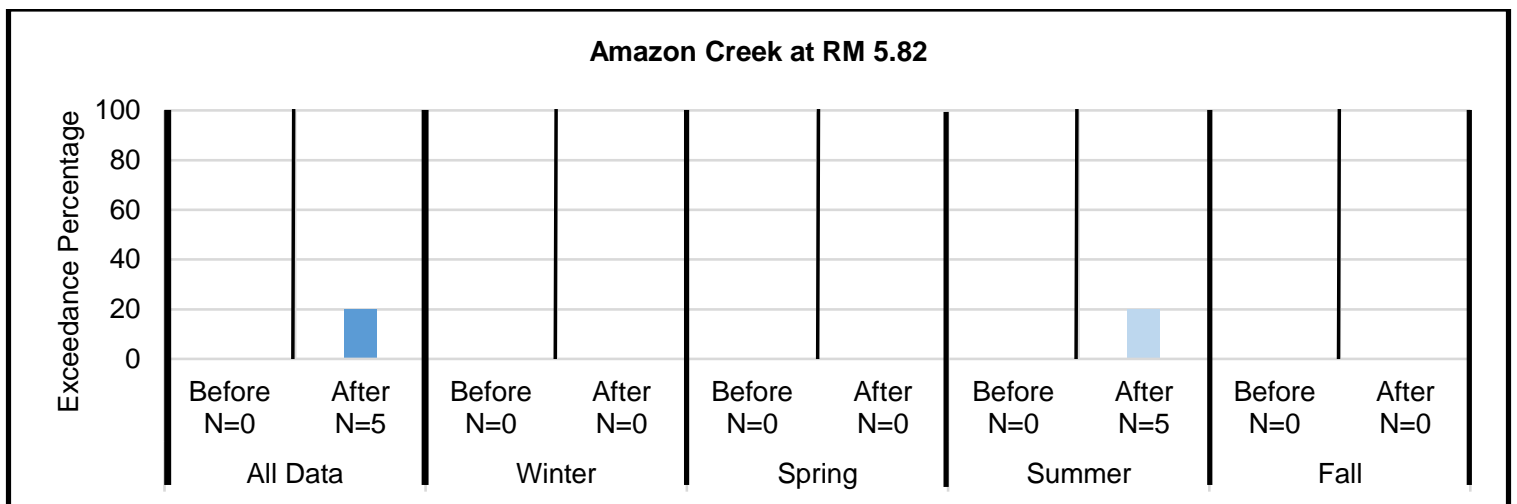

Figure 13: Bar charts of the percentage of single sample E. coli criterion exceedance before and after 2008 on Amazon Creek at RM 5.82. The charts are split seasonally, as well as all data.

Seasonal, mean, and trend differences before and after 2008 at RM 5.82 could not be tested due to the lack of data. However, linear regression analysis could be performed during the summer sampling of 2015, yet no significant trend was found (Figure 14, Appendix D: Table 7).

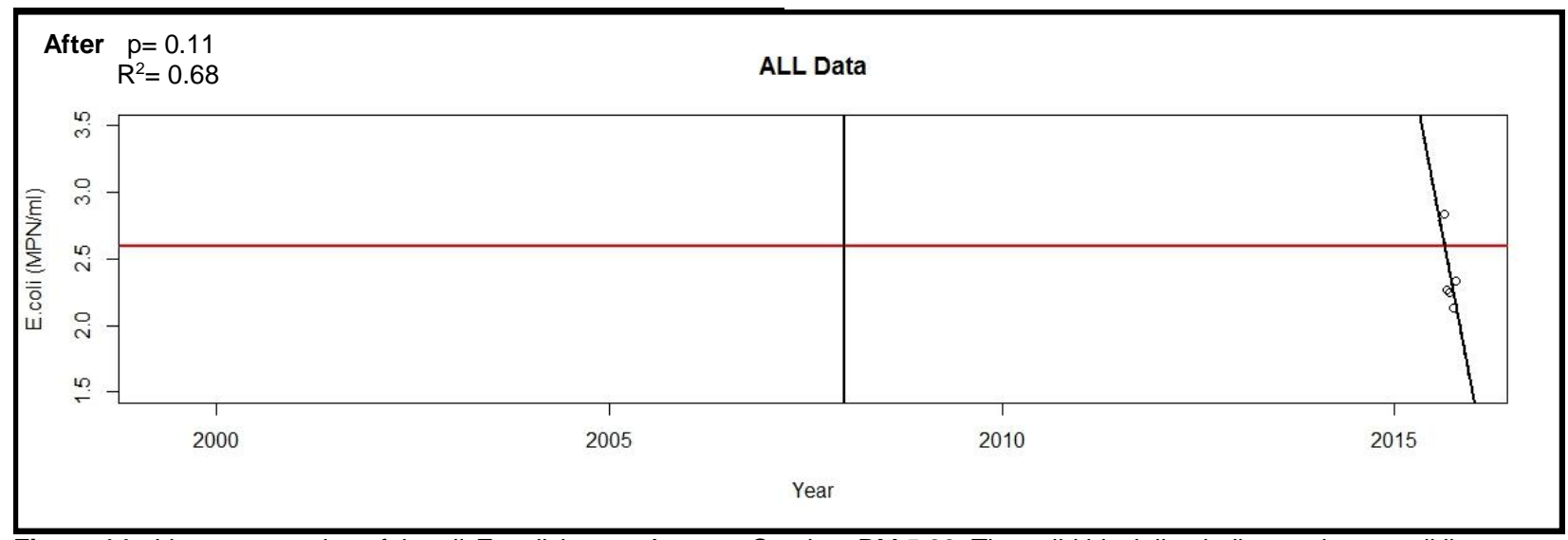

Figure 14: Linear regression of the all E. coli data on Amazon Creek at RM 5.82. The solid black line indicates the overall linear regression. The horizontal red line is the State single sample exceedance level (406 E. coli organisms (MPN)/100 ml).

\section{Amazon Creek at High Pass Road}

Amazon Creek at High Pass Road exceeded the single sample criterion for $E$. coli year-round before and after 2008 (Figure 15, Appendix A: Figure 8, Table 8). The highest percentage of exceedances was during the winter after 2008 (60\%). Exceedances increased during all seasons after 2008 except in the fall, when it decreased $16 \%$. The overall exceedance percentage increased by $3 \%$. The allocated percent reduction in bacterial concentration (58\%) has not been met since 2008. E. coli concentrations have decreased by $10 \%$, on average. 


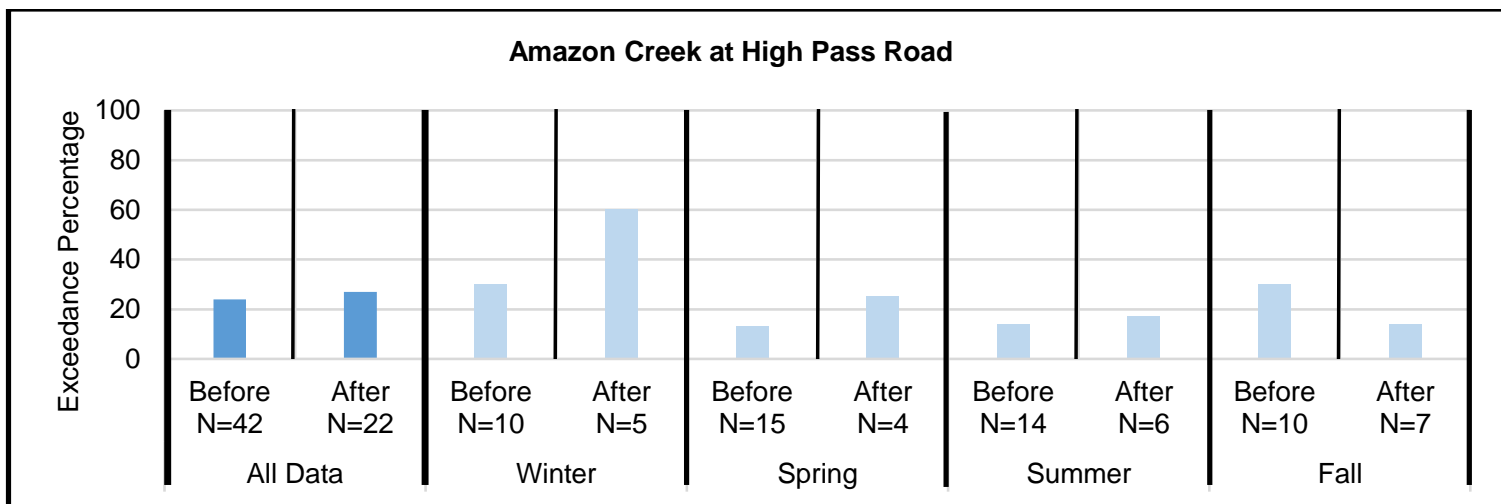

Figure 15: Bar charts of the percentage of single sample E. coli criterion exceedance before and after 2008 on Amazon Creek at High Pass Road. The charts are split seasonally, as well as all data.

Single sample exceedance criterion at High Pass Road was not found to be significantly seasonally dependent before or after 2008 (Appendix B: Table 1 and 2). There were no significant changes found for the means before and after 2008 for any data set (Appendix C:

Table 8). Linear regression analysis found a significant increasing trend during the summer and fall before 2008; but no other dataset was found to be significant (Figure 16, Appendix D: Table 8). There were significant changes found in trend slopes during the summer and the overall data set, although the lack of data during the summer may have affected results. Data had not been collected at High Pass Road from the summer of 2003 through the summer of 2011. The eight year gap in data may have affected the results showing a change in slopes, before and after 2008. The lack of seasonal/yearly data does not allow ARIMA modeling.

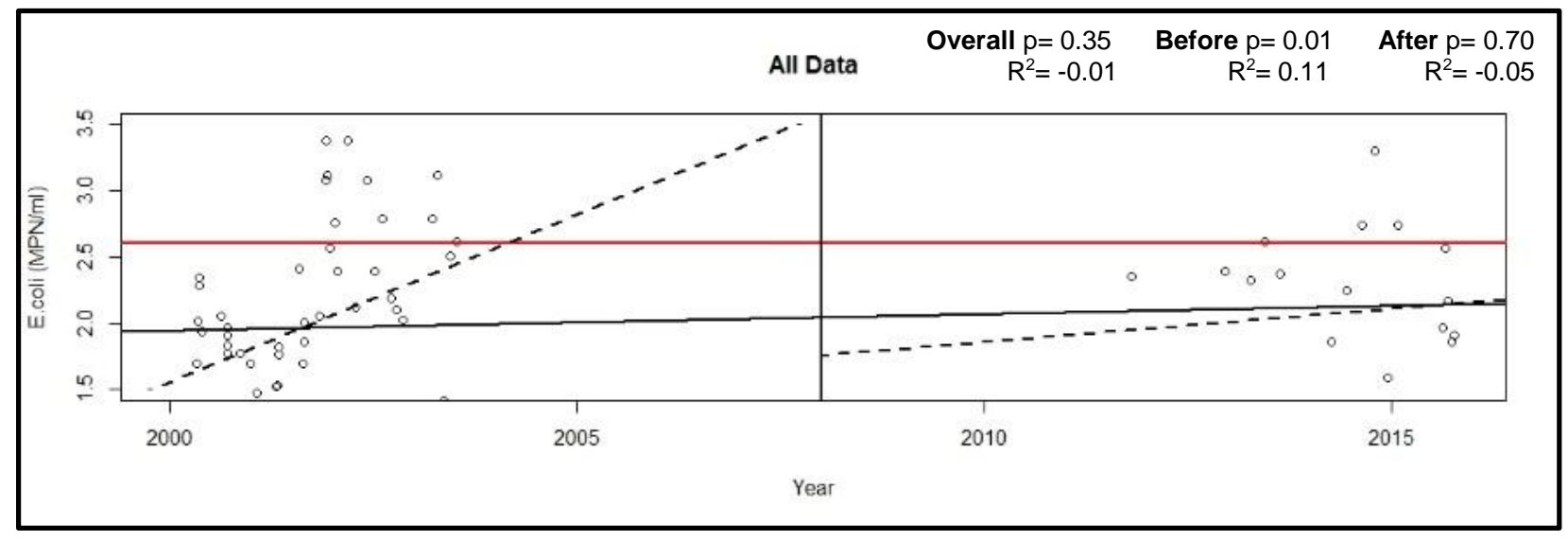




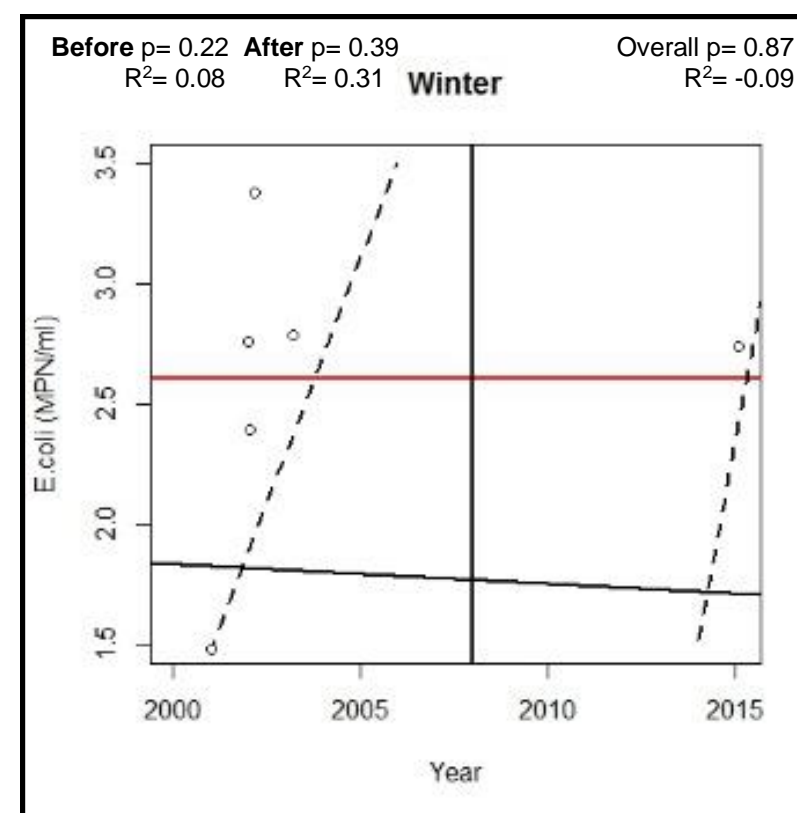
Before $\mathrm{p}=0.21$ After $\mathrm{p}=0.36$
$R^{2}=0.05 \quad R^{2}=0.12$ spring
Overall $p=0.32$
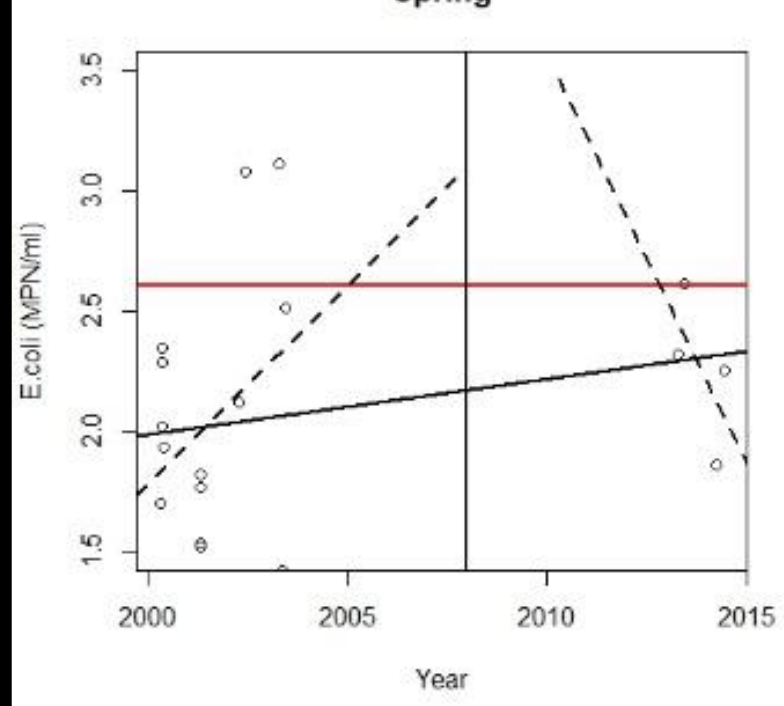

Before $\mathrm{p}=0.04$ After $\mathrm{p}=0.36$

Overall $p=0.18$ $R^{2}=0.26 \quad R^{2}=0.02$ Summer $R^{2}=0.05$

Before $\mathrm{p}=0.02$ After $\mathrm{p}=0.52$ $R^{2}=0.42$

$R^{2}=-0.07$

Fall

Overall $\mathrm{p}=0.82$

m

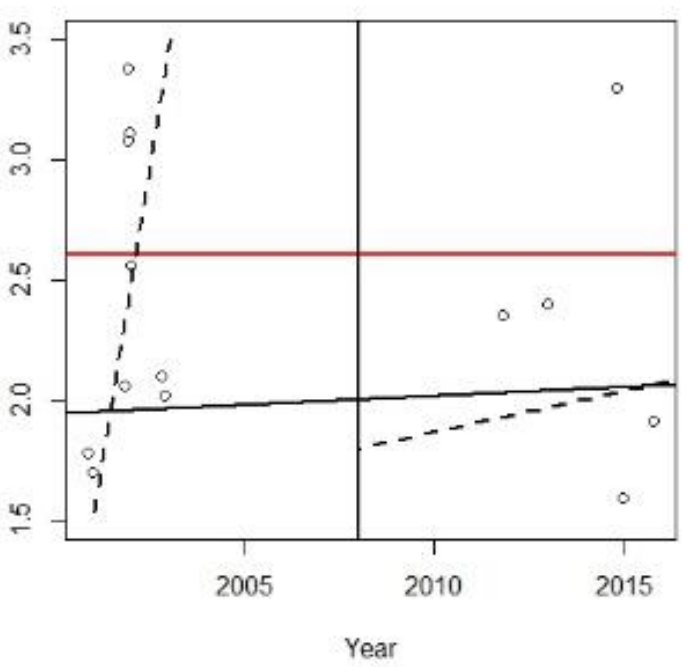

Year

Year

Figure 16: Linear regression of all E. coli data, as well as seasonally, on Amazon Creek at High Pass Road. The E. coli dotted lines indicated linear regression before and/or after 2008. The solid black line indicates the overall linear regression. The horizontal red line is the State single sample exceedance level (406 E. coli organisms (MPN)/100 ml).

\section{Coyote Creek}

\section{Coyote Creek at Hamm Road}

Coyote Creek at Hamm Road did exceed the single sample criterion for E. coli both before and after 2008 (Figure 17, Appendix A: Figure 9, Table 9). Coyote Creek at Hamm Road had not been sampled since the summer of 2001 until the summer of 2015. Single sample exceedance criterion at Hamm Road was not found to be significantly seasonally dependent before 2008 , and could not be tested for seasonal dependence after 2008 (Appendix B: Table 1 and 2). The allocated percent reduction in bacterial concentration (66\%) has not been met since 2008 . $E$. coli concentrations have decreased by $25 \%$, on average. 


\section{Coyote Creek at Hamm Road}

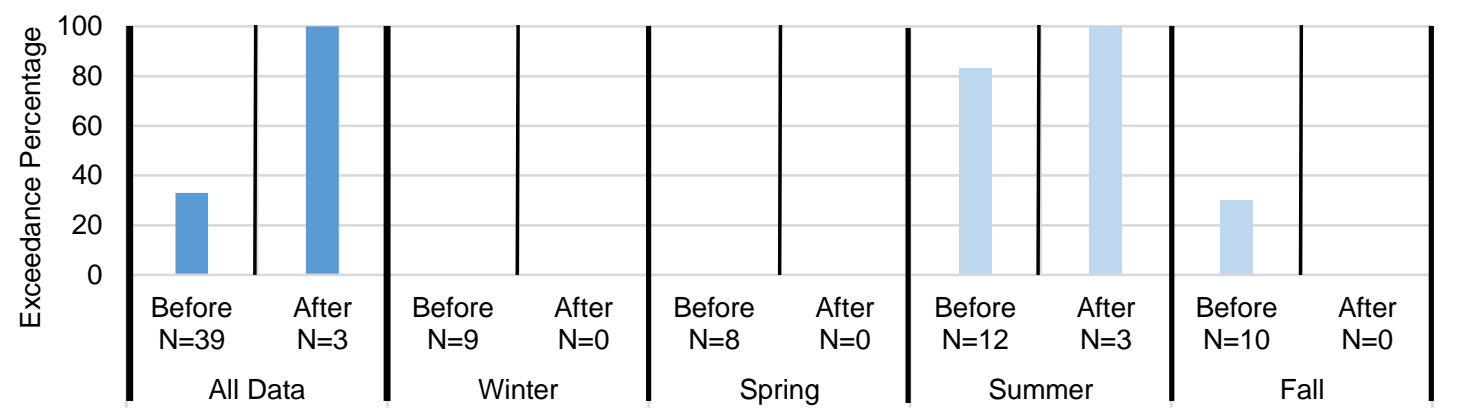

Figure 17: Bar charts of the percentage of single sample E. coli criterion exceedance before and after 2008 on Coyote Creek at Hamm Road. The charts are split seasonally, as well as all data.

Means at Hamm Road were not significantly different during the summer before and after 2008 (Appendix C: Table 9). No other season could be tested due to lack of sampling after 2008. Linear regression analysis found no significant trends and no change in trends during the summer (Figure 18, Appendix D: Table 9). No other season could be tested due to the absence of data after 2008. The lack of seasonal/yearly data did not allow ARIMA modeling.

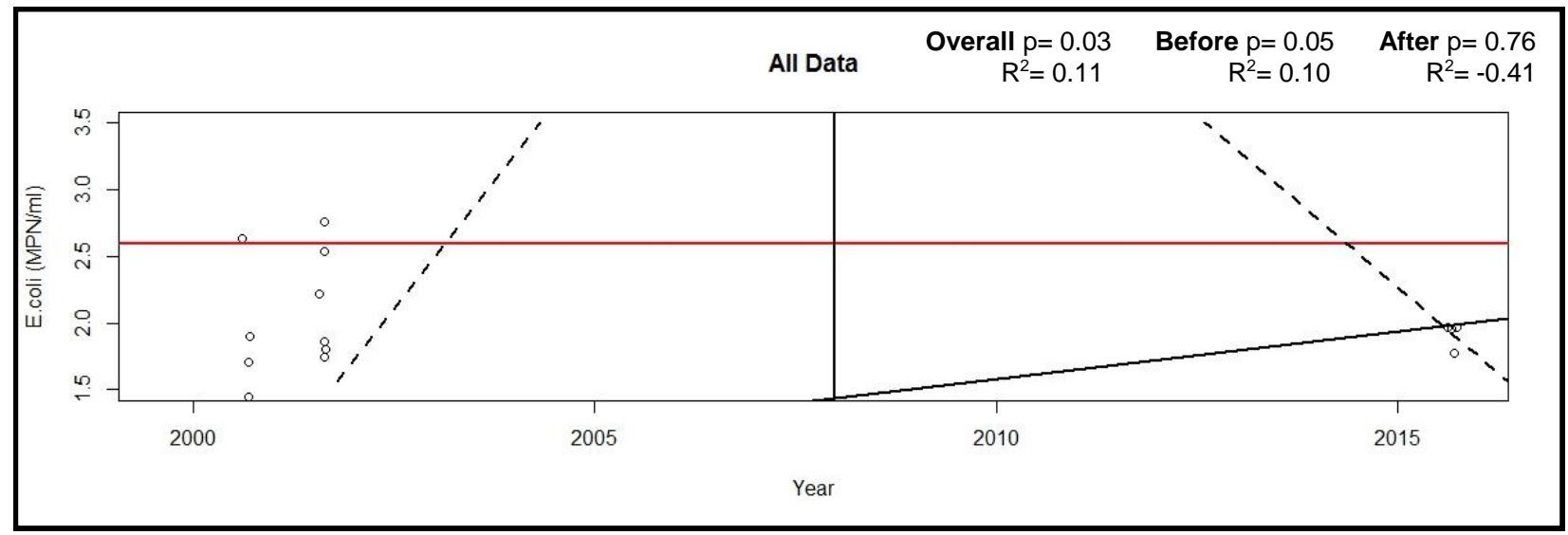




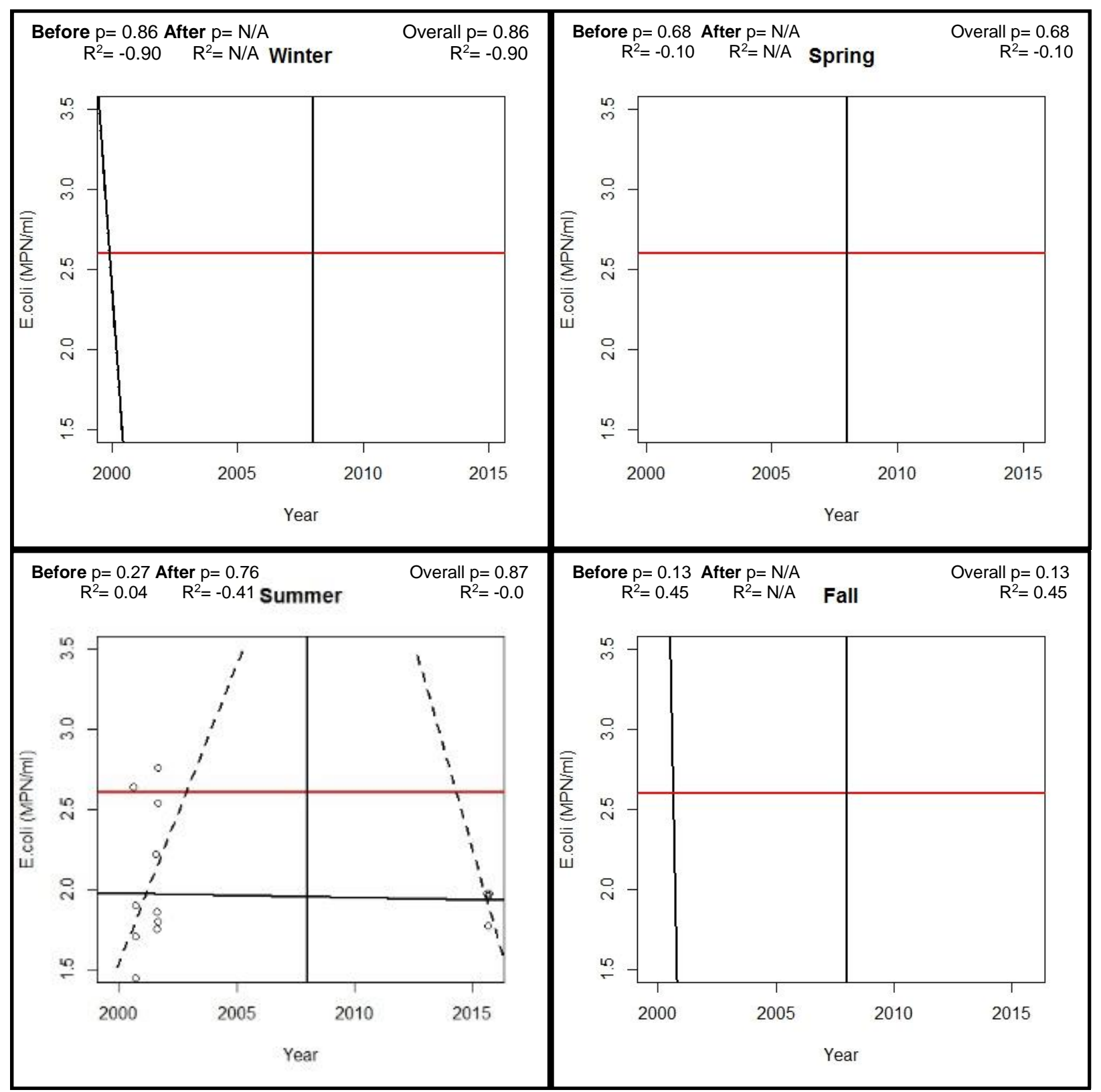

Figure 18: Linear regression of all E. coli data, as well as seasonally, on Coyote Creek at Hamm Road. The dotted lines indicated linear regression before and/or after 2008. The solid black line indicates the overall linear regression. The horizontal red line is the State single sample exceedance level (406 E. coli organisms (MPN)/100 ml).

\section{Coyote Creek at Powell Road}

Coyote Creek at Powell Road exceeded single sample criterion for E. coli during the spring and fall before 2008; but did not exceed after 2008 (Figure 19, Appendix A: Figure 10, Table 10). After samples were collected in the summer of 2001, Coyote Creek at Powell Road had not been sampled until the summer of 2015. Single sample exceedance criterion at Powell Road was found to be significantly seasonally dependent before 2008 , yet could not be tested for seasonal dependence after 2008 (Appendix B: Table 1 and 2). The allocated percent reduction in bacterial concentration (66\%) has not been met since 2008. E. coli concentrations have decreased by $41 \%$, on average. 


\section{Coyote Creek at Powell Road}

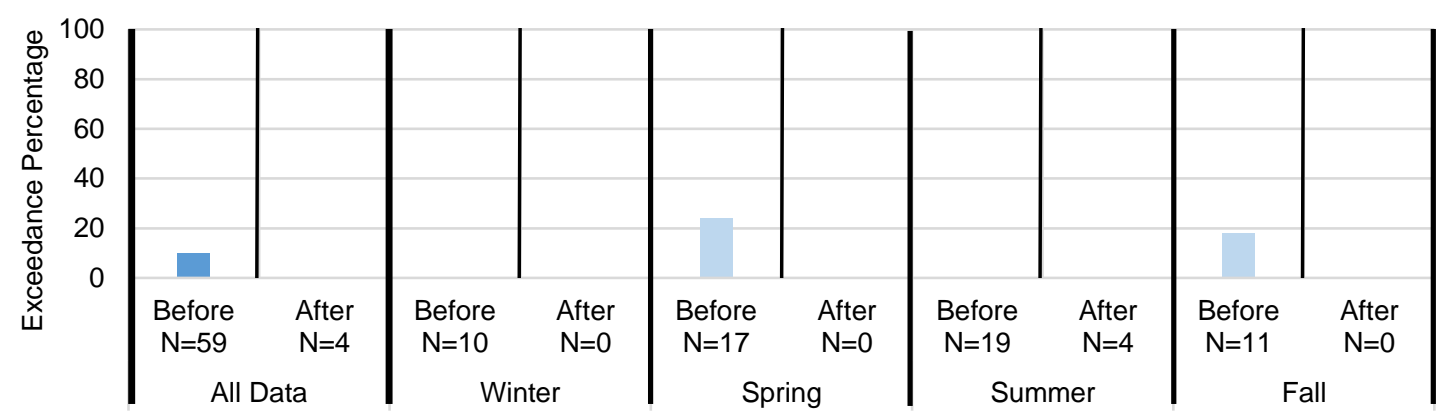

Figure 19: Bar charts of the percentage of single sample E. coli criterion exceedance before and after 2008 on Coyote Creek at Powell Road. The charts are split seasonally, as well as all data.

Means at Powell Road were not significantly different before and after 2008 during the summer (Appendix C: Table 10). No other season could be tested due to lack of sampling after 2008. The spring before 2008 was found to have a significantly decreasing trend, yet no other significant trends where found (Figure 20, Appendix D: Table 10). There were no significant changes in trends before and after 2008 the summer at Powell Road. No other season could be tested due to the absence of data after 2008. The lack of data did not allow ARIMA modeling.

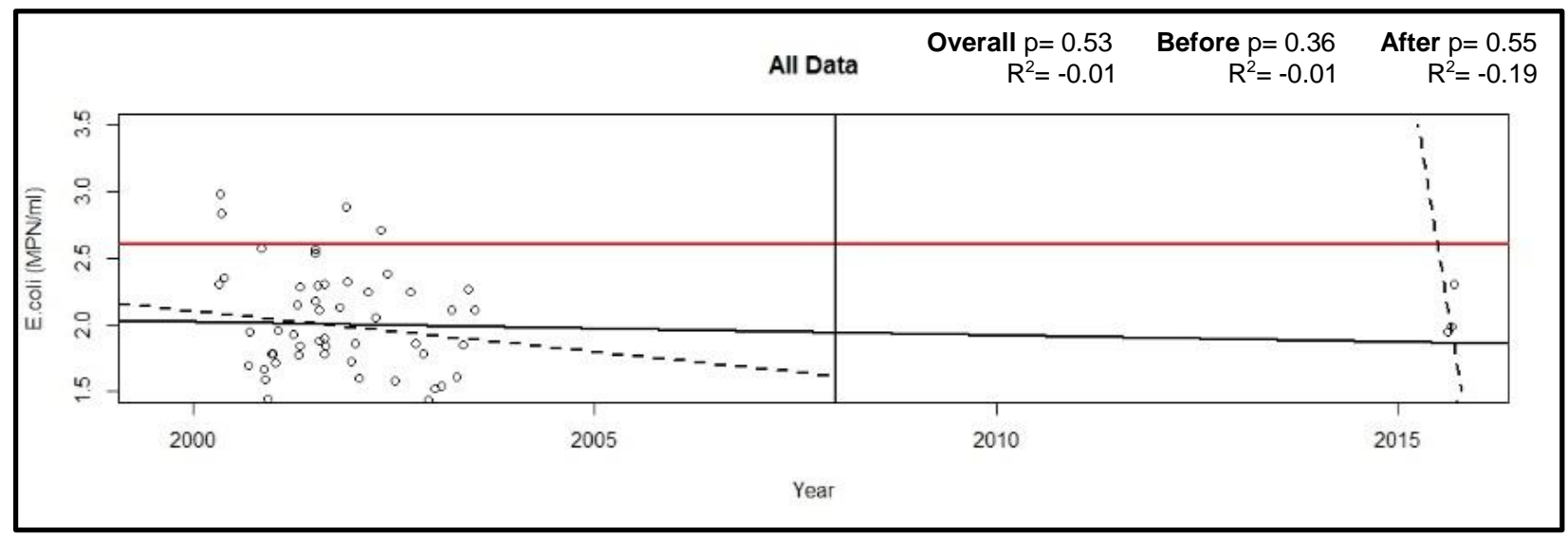




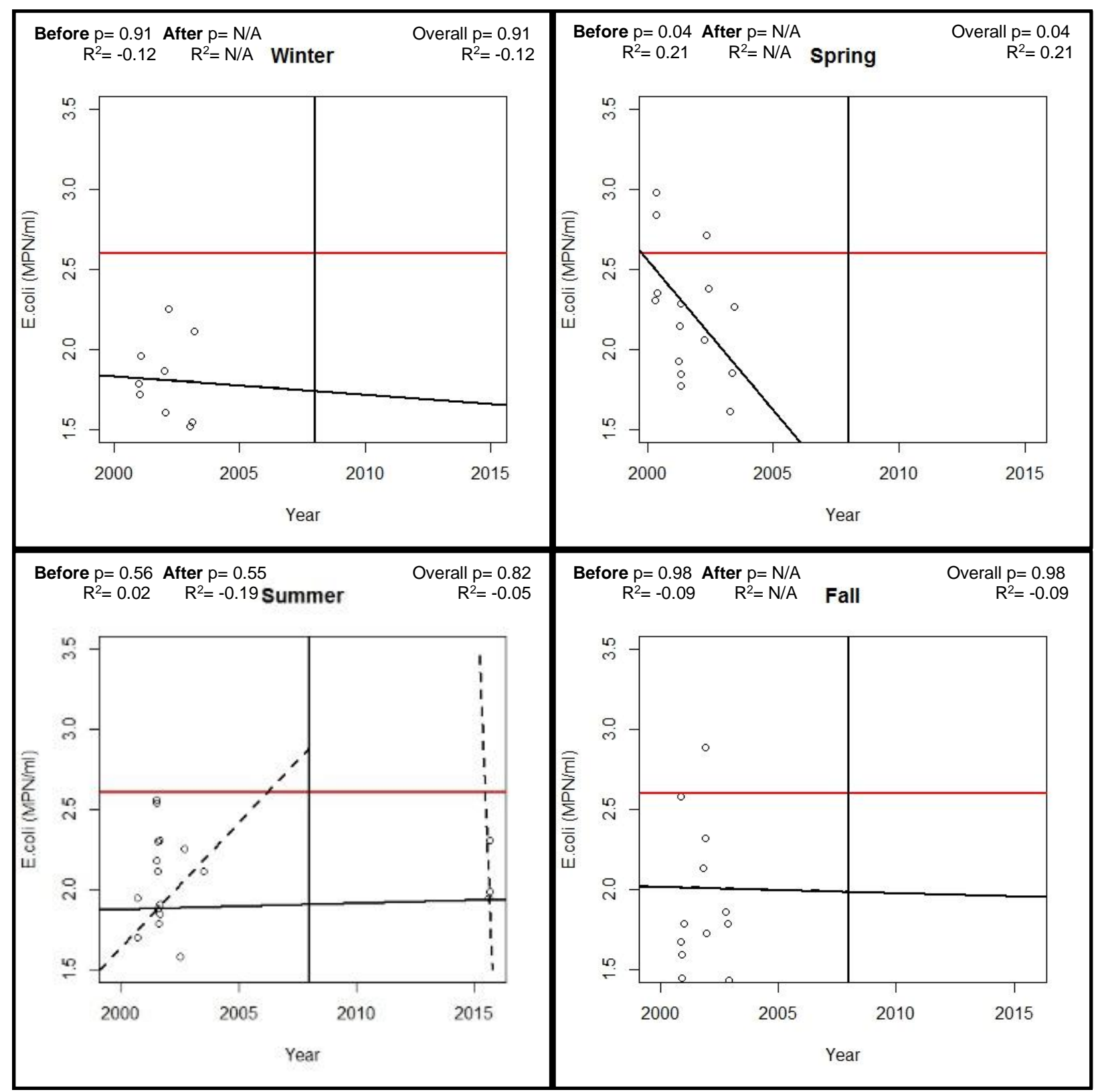

Figure 20: Linear regression of all E. coli data, as well as seasonally, on Coyote Creek at Powell Road. The dotted lines indicated linear regression before and/or after 2008. The solid black line indicates the overall linear regression. The horizontal red line is the State single sample exceedance level 406 E. coli organisms (MPN)/100 ml).

\section{Coyote Creek at Petzold Road}

Coyote Creek at Petzold Road exceeded single sample criterion for E. coli during the winter, spring, and fall before 2008, yet did not exceed after 2008 (Figure 21, Appendix A: Figure 11, Table 11). Coyote Creek at Petzold Road had not been sampled since the summer of 2001 until the summer of 2015. Single sample exceedance criterion at Petzold Road was not found to be significantly seasonally dependent before or after 2008 (Appendix B: Table 1 and 2). The allocated percent reduction in bacterial concentration (66\%) has not been met since 2008. $E$. coli concentrations have decreased by $32 \%$, on average. 


\section{Coyote Creek at Petzold Road}

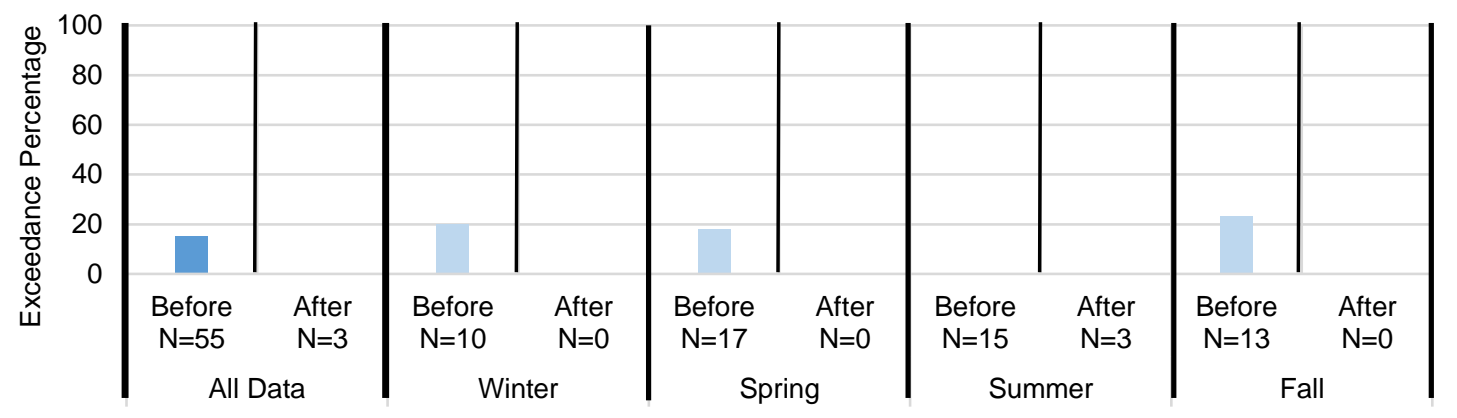

Figure 21: Bar charts of the percentage of single sample E. coli criterion exceedance before and after 2008 on Coyote Creek at Petzold Road. The charts are split seasonally, as well as all data.

Means at Petzold Road were not significantly different before and after 2008 during the summer (Appendix C: Table 11). No other season could be tested due to lack of sampling after 2008. Linear regression analysis found no significant trends or change in trends during the summer (Figure 22, Appendix D: Table 11). No other season could be tested due to the absence of data after 2008. The lack of seasonal/yearly data does not allow ARIMA modeling to forecast as well.

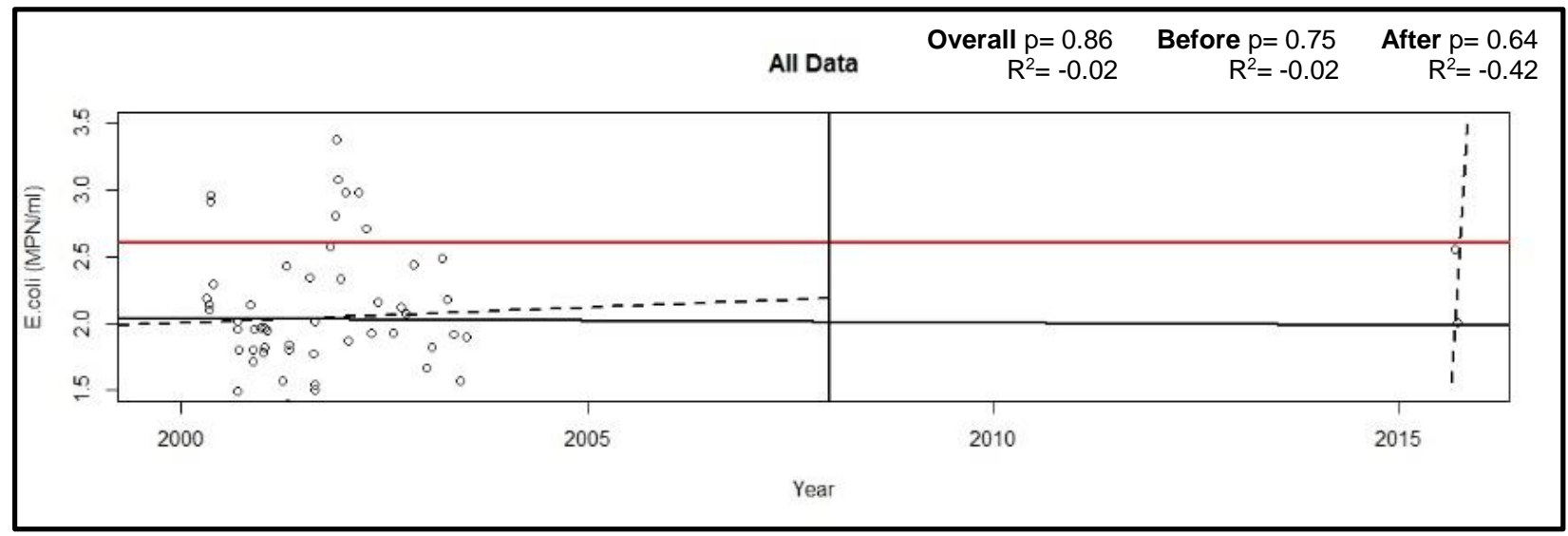




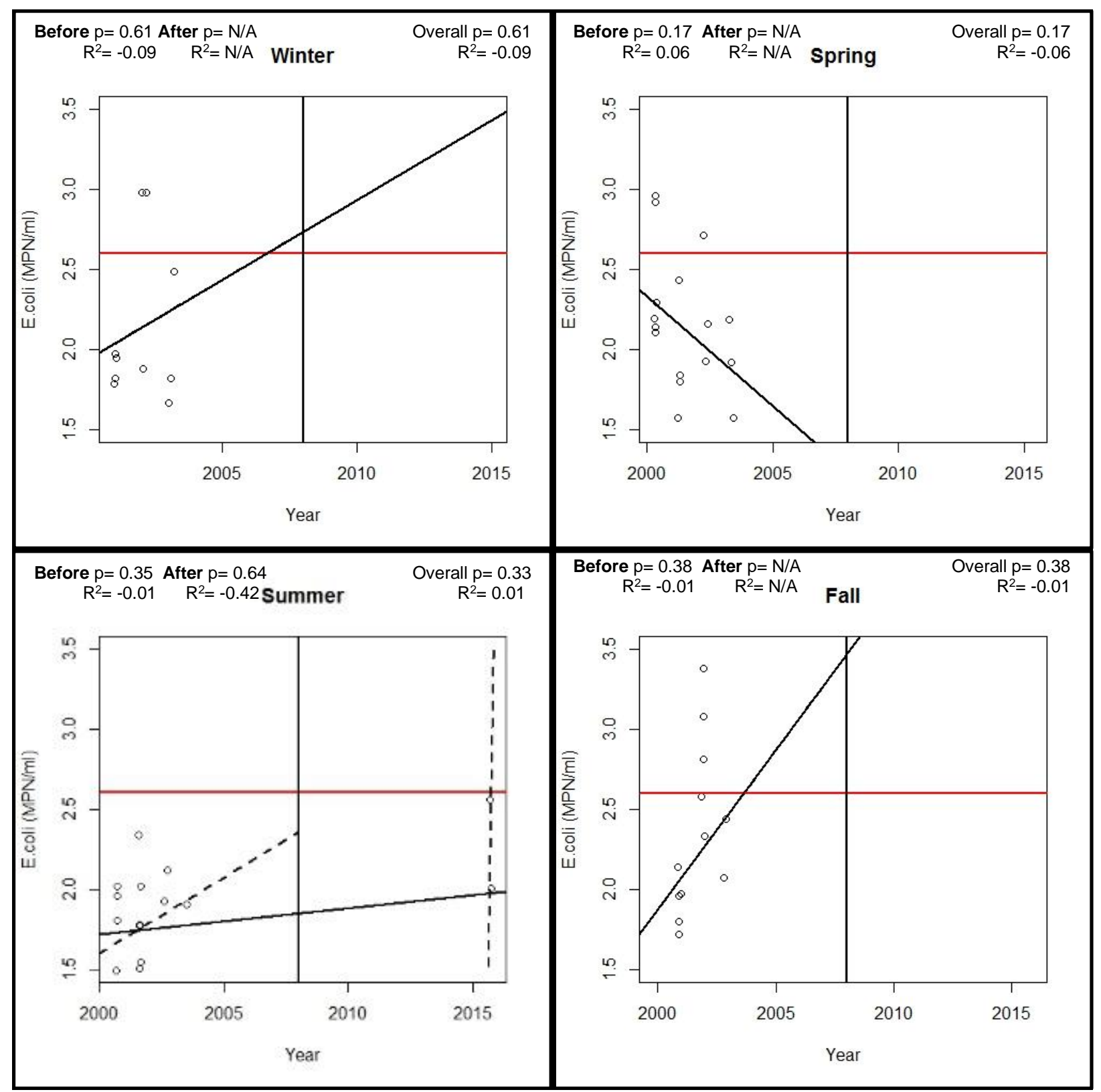

Figure 22: Linear regression of all E. coli data, as well as seasonally, on Coyote Creek at Petzold Road. The dotted lines indicated linear regression before and/or after 2008. The solid black line indicates the overall linear regression. The horizontal red line is the State single sample exceedance level (406 E. coli organisms (MPN)/100 ml).

\section{Dissolved Oxygen}

\section{Upper Amazon}

\section{Amazon Creek at $29^{\text {th }}$ Avenue}

Amazon Creek at $29^{\text {th }}$ Avenue exceeded the single sample criterion for DO during the summer before and after 2008 (Figure 23, Appendix A: Figure 12, Table 12). Single sample exceedances at $29^{\text {th }}$ Avenue were found to be significantly seasonally dependent before 2008 but not after 2008 (Appendix B: Table 3 and 4). During the summer before 2008, single sample 
criterion was exceeded $16 \%$ of the times sampled. Exceedances have decreased by $9 \%$ since 2008. The allocated percent reduction in nutrient concentration, BOD concentration, and SOD concentration (40\%) has not been met since 2008; ammonia has decreased by $17 \%$, nitrate/nitrite as $\mathrm{N}$ has increased by $9 \%$, total phosphorus has decreased by $9 \%$, TSS has increased by $15 \%$, and BOD has increased by $97 \%$ (Appendix F: Tables 1, 3, 5, 6, and 7). The average temperature before and after 2008 has not changed (Appendix F: Table 2).

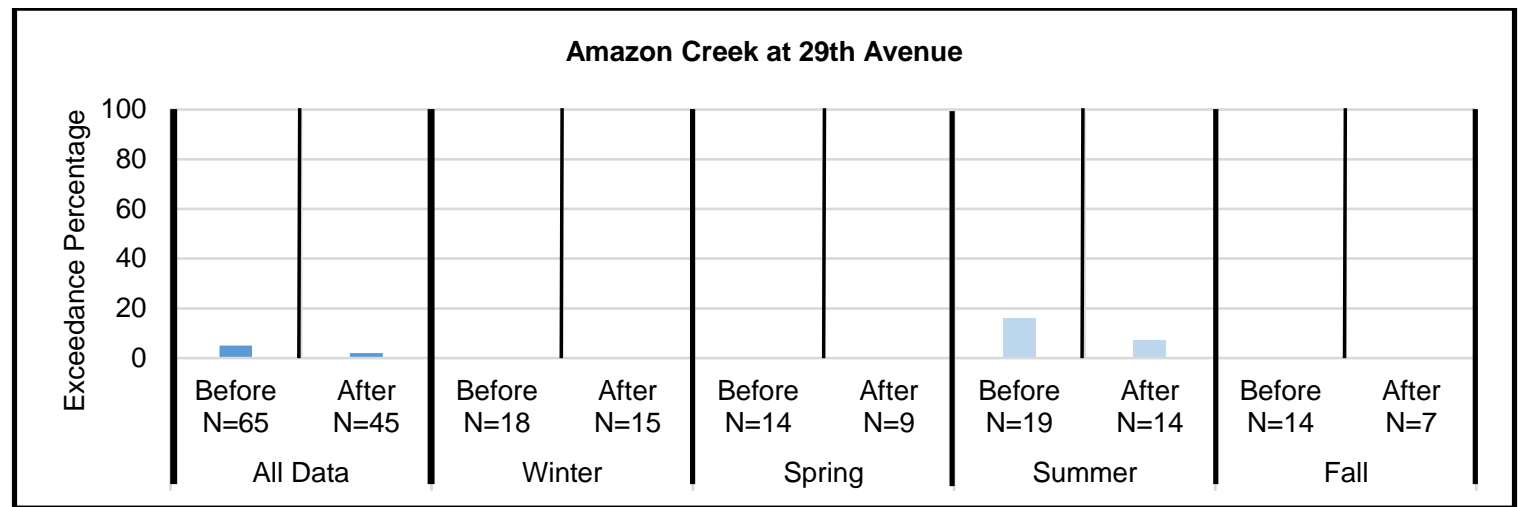

Figure 23: Bar charts of the percentage of single sample DO criterion exceedance before and after 2008 on Amazon Creek at $29^{\text {th }}$ Avenue. The charts are split seasonally, as well as all data.

$29^{\text {th }}$ Avenue was found to have significant change in means during the summer (Appendix C: Table 12). Linear regression analysis found a significantly increasing trend during the summer after 2008 (Figure 24, Appendix D: Table 12). The summers before and after 2008 also had significantly different slopes. The high variability among samples along with minimal seasonal/yearly data collection made forecasting DO concentration with auto ARIMA modeling unreliable. The model forecasted a slightly decreasing mean, yet the lower $95 \%$ confidence interval does not extend below the single sample criterion (Appendix E:Figure 6).

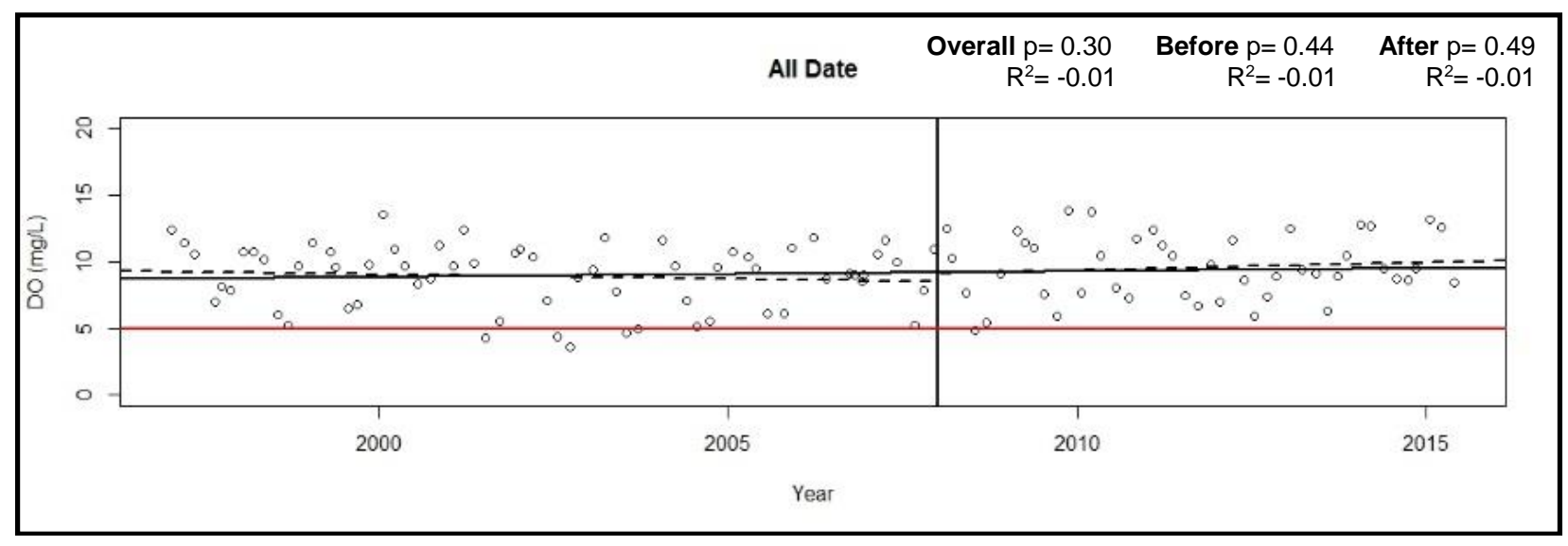




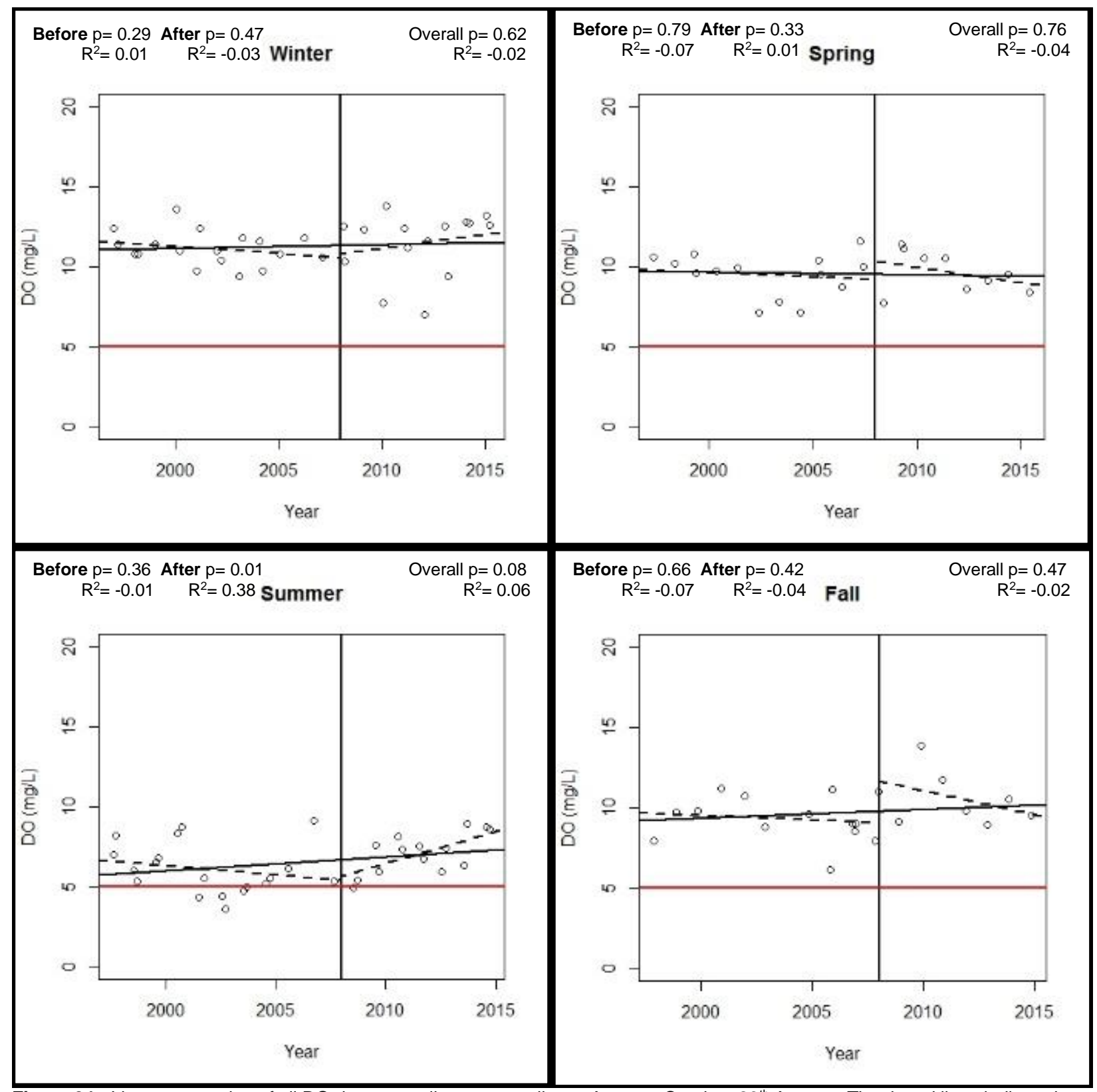

Figure 24: Linear regression of all DO data, as well as seasonally, on Amazon Creek at $29^{\text {th }}$ Avenue. The dotted lines indicated linear regression before and/or after 2008. The solid black line indicates the overall linear regression. The horizontal red line is the State single sample exceedance level $(5.0 \mathrm{mg} / \mathrm{L})$.

\section{Amazon Creek at Railroad Crossing}

Amazon Creek at Railroad Crossing exceeded single sample criterion for DO during the spring, summer, and fall before 2008 and winter, spring, and summer after 2008 (Figure 25, Appendix A: Figure 13, Table 13). Overall exceedances have decreased by $4 \%$. Single sample exceedances at Railroad Crossing was found to be significantly seasonally dependent before 2008 but not after 2008 (Appendix B: Table 3 and 4). The allocated percent reduction in nutrient concentration, BOD concentration, and SOD concentration (40\%) has not been met since 2008; ammonia has increased by $40 \%$, nitrate/nitrite as $\mathrm{N}$ has increased by $20 \%$, total phosphorus has increased by $9 \%$, TSS has increased by $4 \%$, and BOD has increased by $19 \%$ (Appendix F: 
Tables 9, 11, 13, 14, and 15). The average temperature before and after 2008 has decreased by $7 \%$ changed (Appendix F: Table 10).

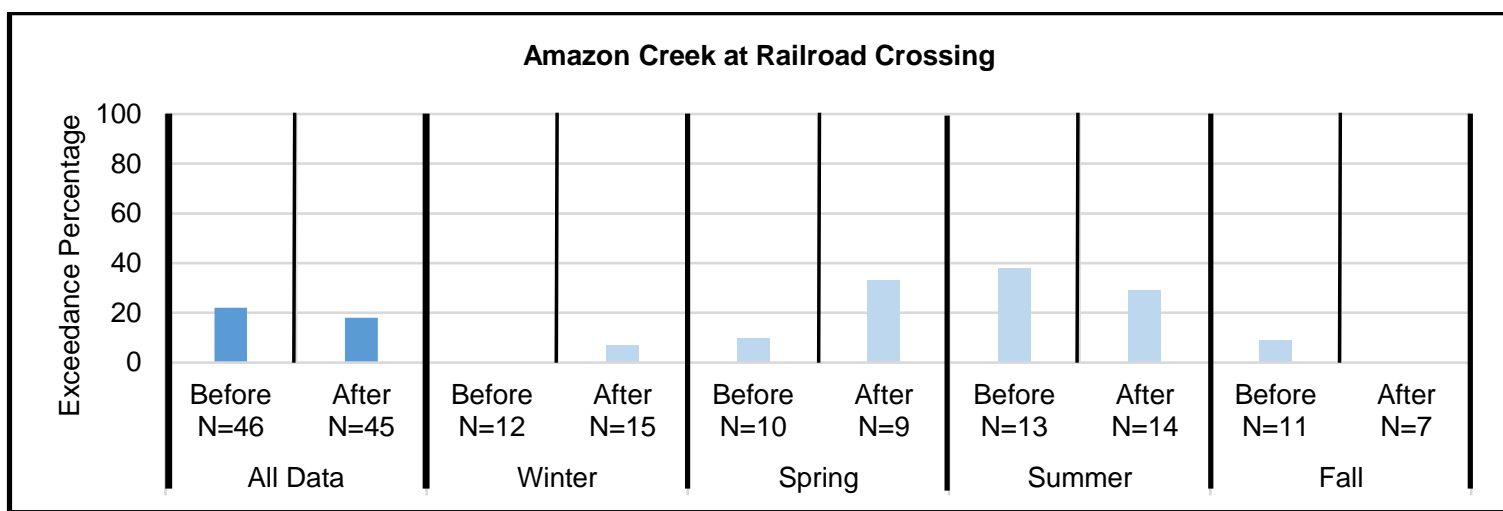

Figure 25: Bar charts of the percentage of single sample DO criterion exceedance before and after 2008 on Amazon Creek at Railroad Crossing. The charts are split seasonally, as well as all data.

Railroad Crossing did not have significant differences in means for any data set (Appendix C: Table 13). Linear regression analysis found a significantly decreasing trend during the fall before 2008, yet no other data set was found to be significant (Figure 26, Appendix D: Table 13). There were no significant changes found in any of the slopes before and after 2008 . The high variability among samples along with minimal seasonal/yearly data collection caused uncertainty in DO forecasting via ARIMA modeling. The model forecasted a slightly increasing mean, yet the lower $95 \%$ confidence interval does extend below the single sample criterion year-round (Appendix E: Figure 7).

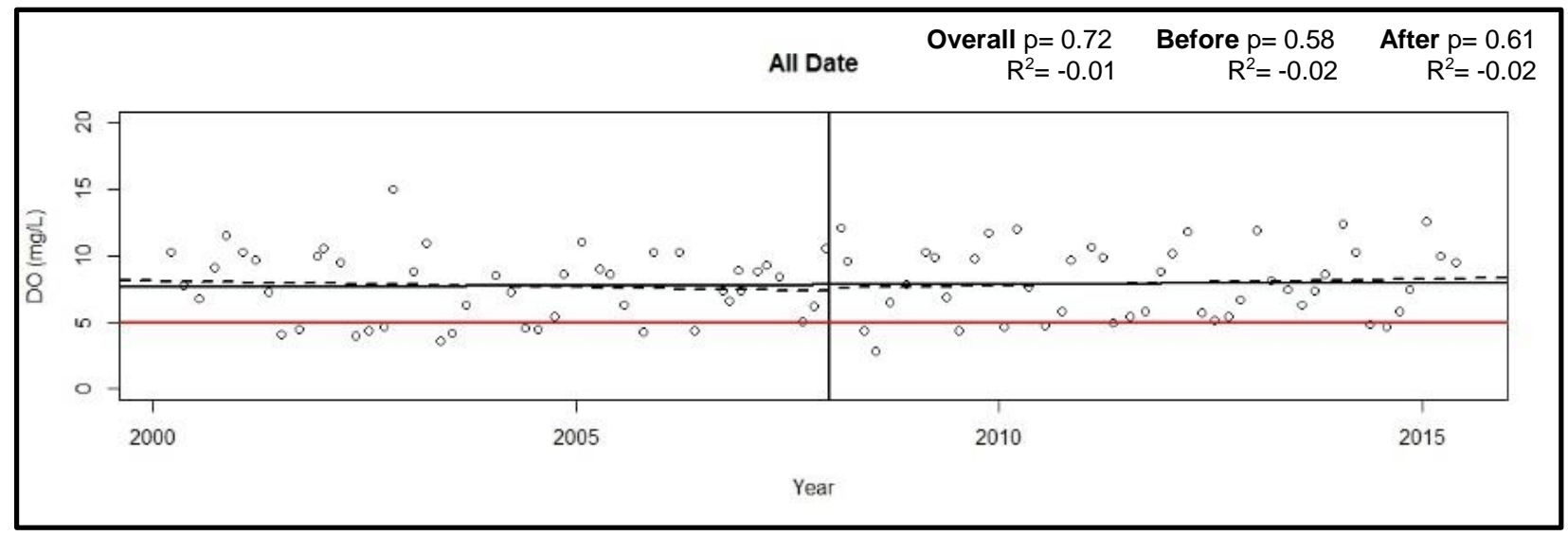




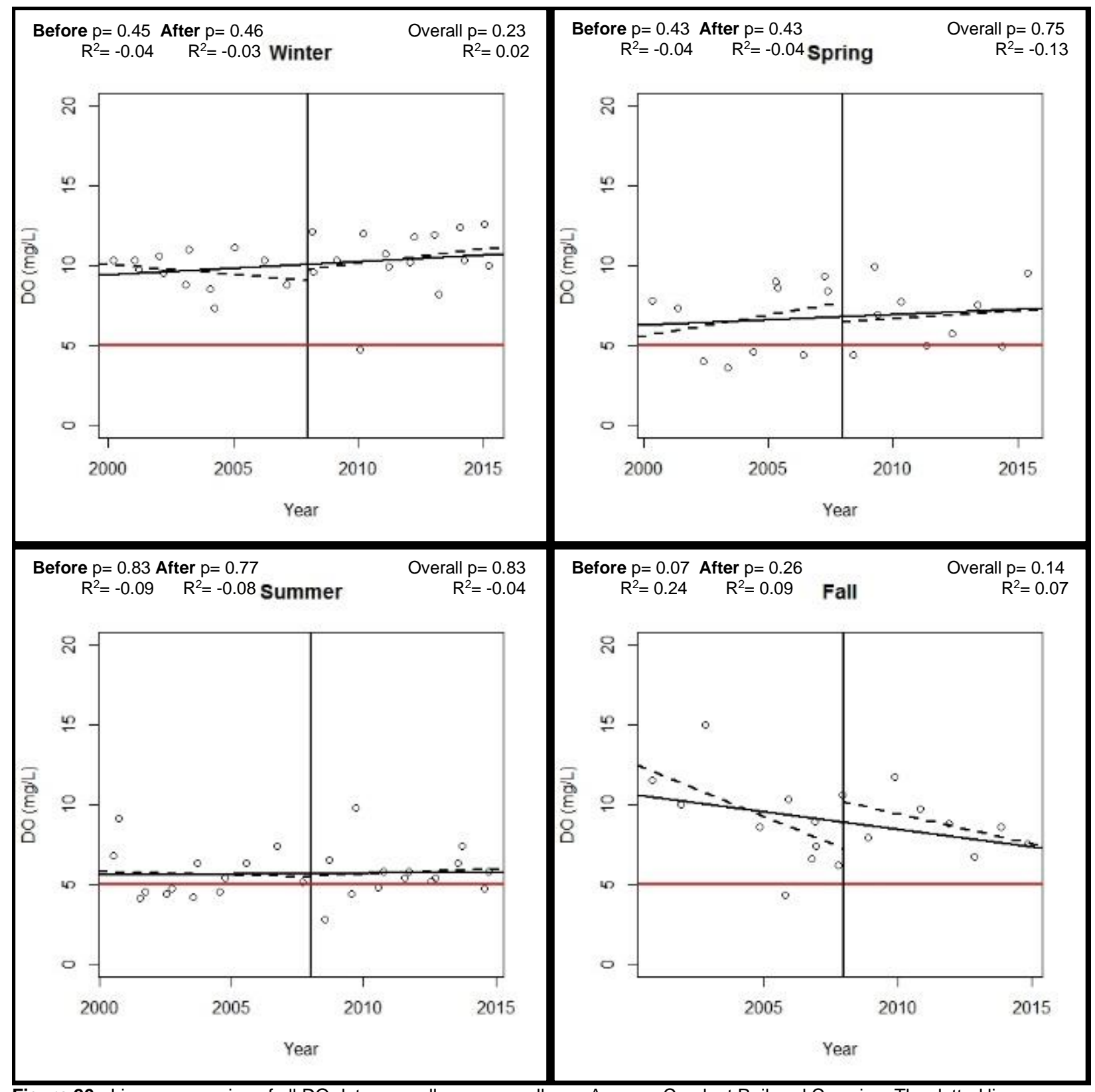

Figure 26: Linear regression of all DO data, as well as seasonally, on Amazon Creek at Railroad Crossing. The dotted lines indicated linear regression before and/or after 2008. The solid black line indicates the overall linear regression. The horizontal red line is the State single sample exceedance level $(5.0 \mathrm{mg} / \mathrm{L})$.

\section{Amazon Creek at Royal Avenue}

Amazon Creek at Royal Avenue exceeded the single sample criterion for DO during the spring and summer before and after 2008 (Figure 27, Appendix A: Figure 14, Table 14). The percentage of exceedances during the spring and summer has increased by $8 \%$ and $10 \%$ respectively. DO data during the both the winter and fall, both before and after 2008, did not exceeded the single sample criterion. Single sample exceedances at Royal Avenue were found to be significantly seasonally dependent both before and after 2008 (Appendix B: Table 3 and 4). The allocated percent reduction in nutrient concentration, BOD concentration, and SOD concentration (40\%) has not been met since 2008; ammonia has decreased by $75 \%$, nitrate/nitrite as $\mathrm{N}$ has decreased by $27 \%$, total phosphorus has decreased by $17 \%$, TSS has 
decreased by $21 \%$, and BOD has decreased by $11 \%$ (Appendix F: Tables 16, 18, 20, 21, and 22). The average temperature before and after 2008 has decreased by $15 \%$ changed (Appendix F: Table 17).

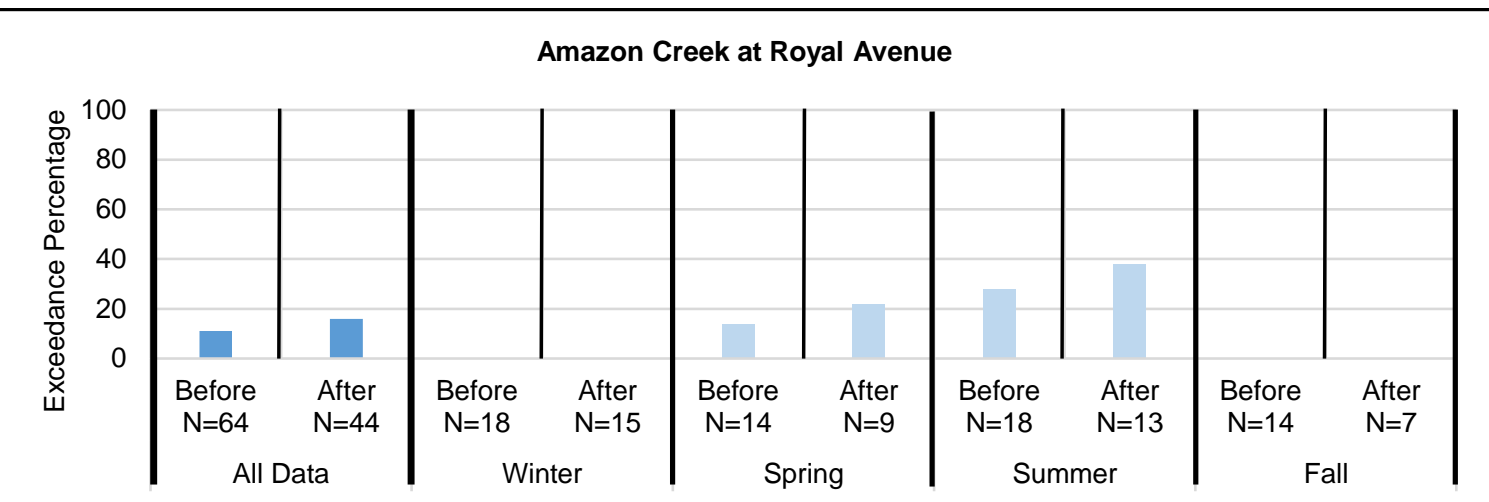

Figure 27: Bar charts of the percentage of single sample DO criterion exceedance before and after 2008 on Amazon Creek at Royal Avenue. The charts are split seasonally, as well as all data.

Royal Avenue was found to have a significant change in means during the summer (Appendix C: Table 14). Linear regression analysis did not find any significant trends within any data set (Figure 28, Appendix D: Table 14). There were no significant changes found in the slopes of any data set before and after 2008. The high variability of each sample collection, paired with minimal seasonal/yearly data collection caused unreliability to forecast DO concentration through auto ARIMA modeling. The model forecasted a little to no change in the overall mean, yet the lower $95 \%$ confidence interval does extend below the State single sample criterion yearround (Appendix E: Figure 8).

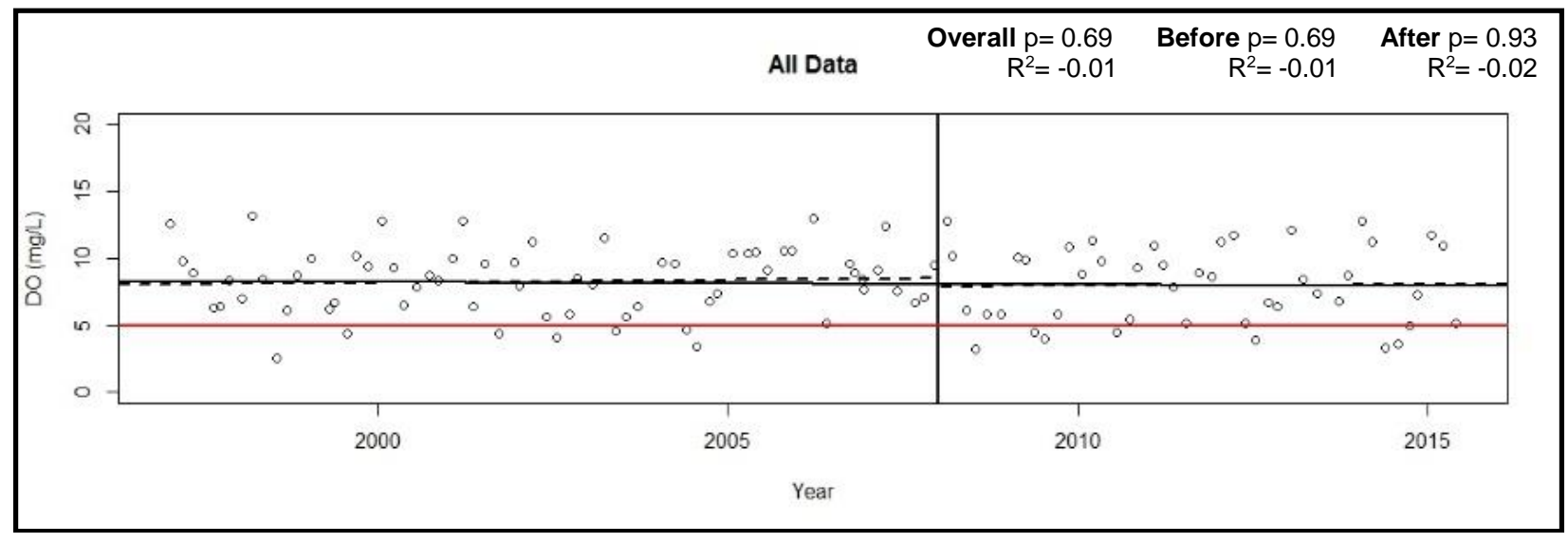




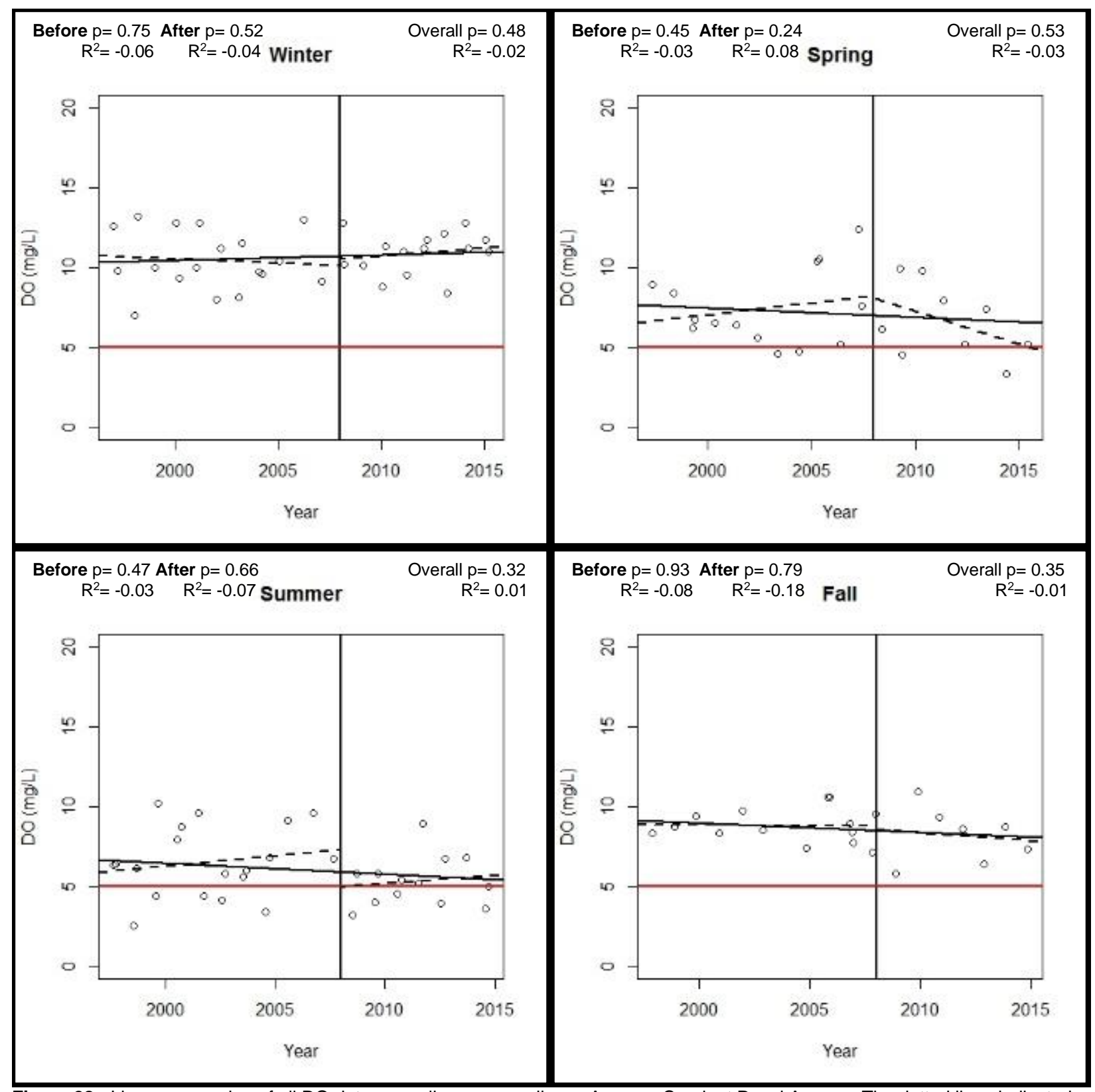

Figure 28: Linear regression of all DO data, as well as seasonally, on Amazon Creek at Royal Avenue. The dotted lines indicated linear regression before and/or after 2008. The solid black line indicates the overall linear regression. The horizontal red line is the State single sample exceedance level $(5.0 \mathrm{mg} / \mathrm{L})$.

\section{Willow Creek at $18^{\text {th }}$ Avenue}

Willow Creek at 18th Avenue exceeded single sample criterion for DO during the winter after 2008 and the summer before 2008 (Figure 29, Appendix A: Figure 15, Table 15). Single sample criterion was only exceeded once before and once after 2008. Single sample exceedances at Willow Creek were not significantly seasonally different before 2008 or after 2008 (Appendix B: Table 3 and 4). The allocated percent reduction in nutrient concentration, BOD concentration, and SOD concentration (40\%) has not been met since 2008; ammonia has increased by $67 \%$, nitrate/nitrite as $\mathrm{N}$ has decreased by $38 \%$, total phosphorus has not changed, TSS has decreased by $31 \%$, and BOD has decreased by $27 \%$ (Appendix F: Tables 24, 26, 28, 29, and 
30). The average temperature before and after 2008 has decreased by $15 \%$ changed (Appendix F: Table 25).

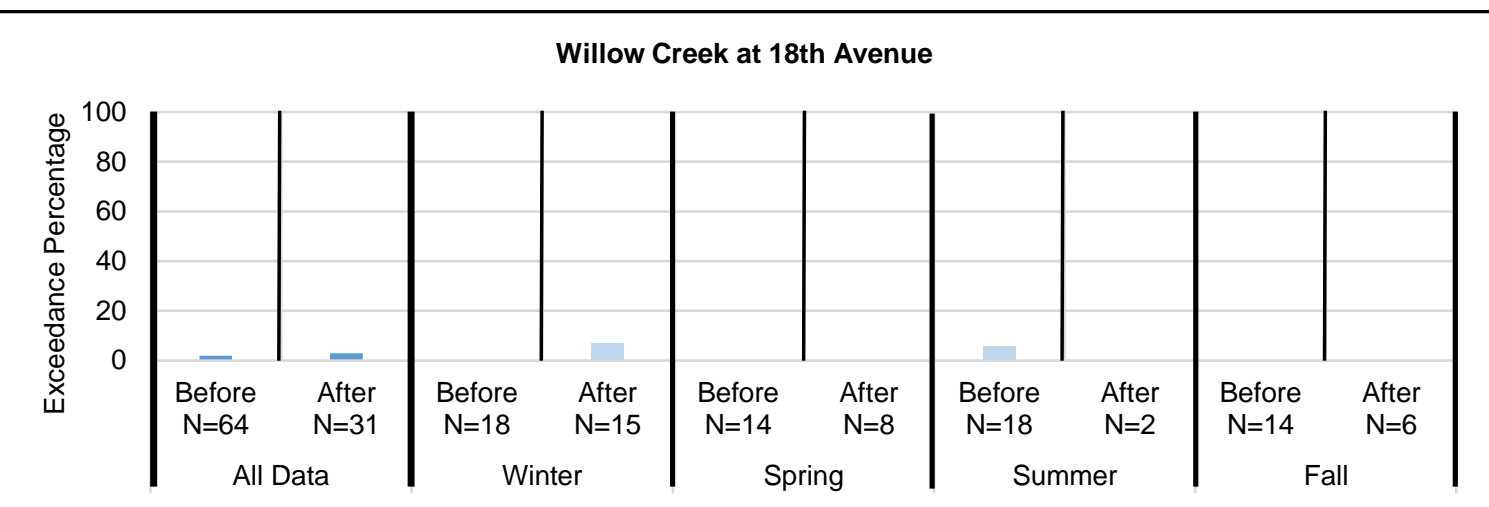

Figure 29: Bar charts of the percentage of single sample DO criterion exceedance before and after 2008 on Willow Creek at $18^{\text {th }}$ Avenue. The charts are split seasonally, as well as all data.

Willow Creek had a significant difference in means during the winter as well as the overall data concentration levels (Appendix C: Table 15). Overall trend for all seasons, as well as the overall data set, was increasing, implying improving DO concentration levels after 2008. Linear regression analysis found that the winter before 2008 had a significantly decreasing trend (Figure 30, Appendix D: Table 15). There was a significant difference in the trends during the winter. The lack of data during the summer after 2008 did not allow linear regression analysis or testing for changes in means or slopes. Also, the lack of seasonal/yearly data did not allow ARIMA modeling.

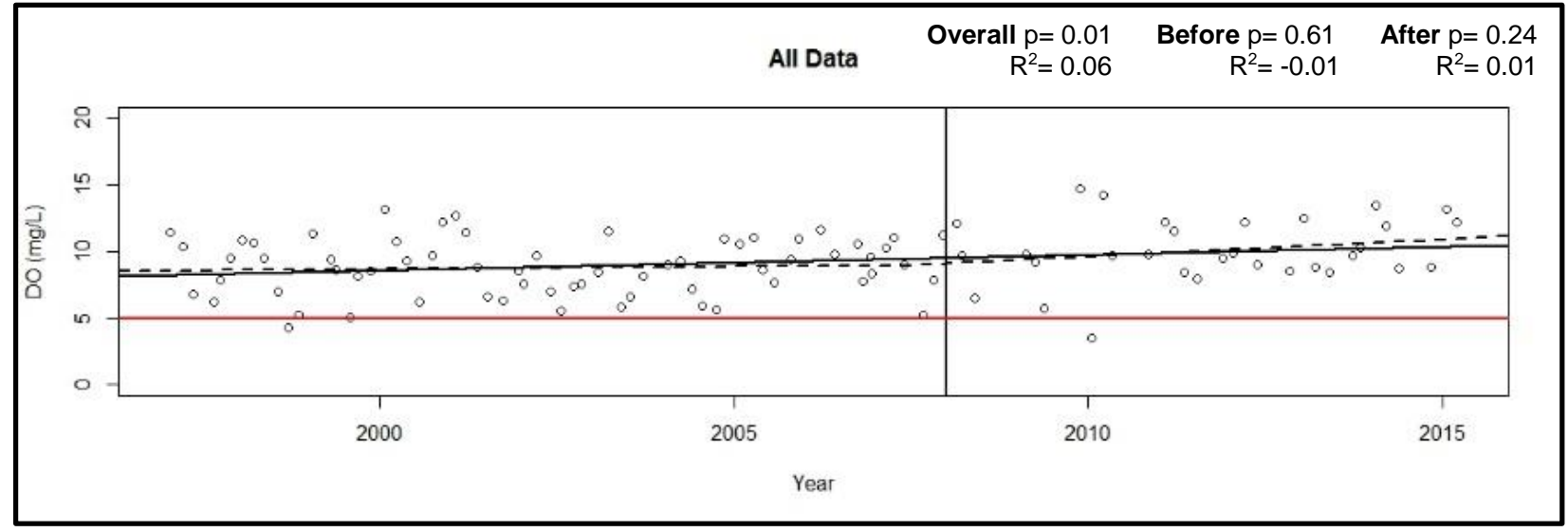




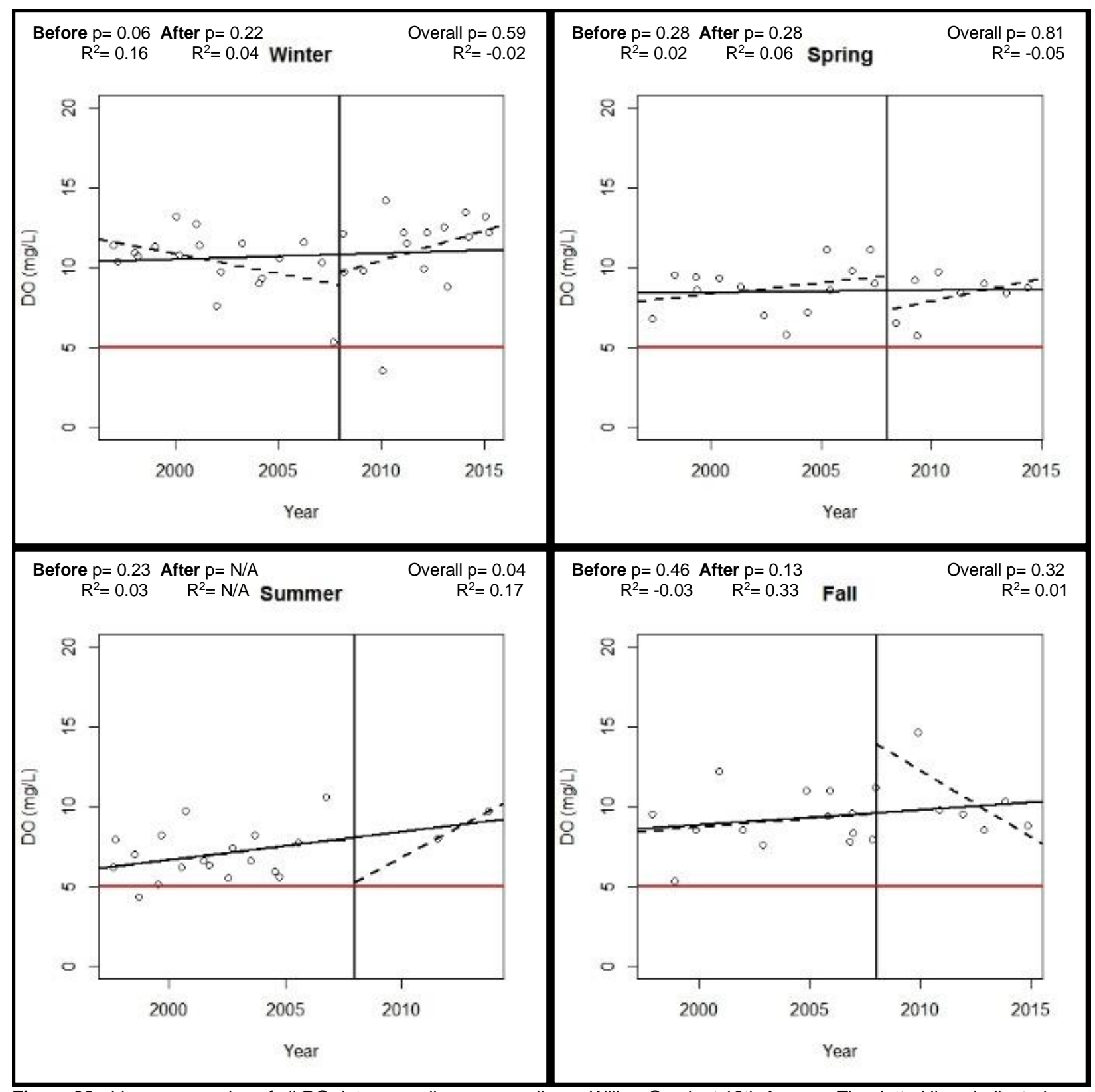

Figure 30: Linear regression of all DO data, as well as seasonally, on Willow Creek at 18th Avenue. The dotted lines indicated linear regression before and/or after 2008. The solid black line indicates the overall linear regression. The horizontal red line is the State single sample exceedance level $(5.0 \mathrm{mg} / \mathrm{L})$.

\section{Amazon Diversion Channel at Royal Avenue}

Amazon Diversion Channel at Royal Avenue exceeded the single sample criterion for DO during the summer before 2008 and during spring, summer, and fall after 2008 (Figure 31, Appendix A: Figure 16, Table 16). Single sample exceedances increased by $22 \%$ during the spring and decreased by $25 \%$ during the summer after 2008. Single sample exceedances in the Amazon Diversion Channel at Royal Avenue were significantly seasonally different before 2008 but not after 2008 (Appendix B: Table 3 and 4). The allocated percent reductions in nutrient concentration, BOD concentration, and SOD concentration (40\%) has not been met since 2008; ammonia did not change, nitrate/nitrite as $\mathrm{N}$ has decreased by $13 \%$, total phosphorus has decreased by $11 \%$, TSS has increased by $14 \%$, and BOD has decreased by $20 \%$ (Appendix F: 
32, 34, 36, 37, and 38). The average temperature before and after 2008 has decreased by $11 \%$ changed (Appendix F: Table 33).

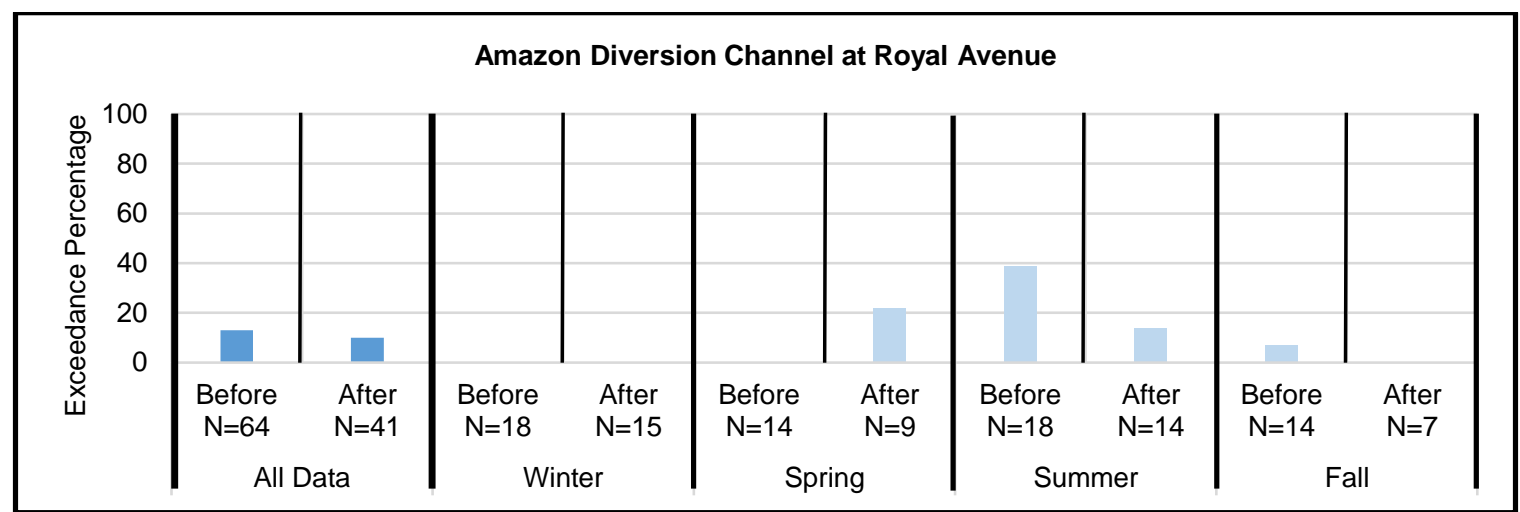

Figure 31: Bar charts of the percentage of single sample DO criterion exceedance before and after 2008 on Amazon Diversion Channel at Royal Avenue. The charts are split seasonally, as well as all data.

Amazon Diversion Channel did not have a significant difference in means before and after 2008 (Appendix C: Table 16). Linear regression analysis found the summer before 2008 to be the only data set with a significant trend (Figure 32, Appendix D: Table 16). There were no significant differences in the trends of any dataset. The high variability among samples along with minimal seasonal/yearly data collection caused uncertain forecasting of DO concentrations via ARIMA modeling. The model forecasted no change in the mean, yet the lower $95 \%$ confidence interval did extend below the State single sample criterion year-round (Appendix E: Figure 9).

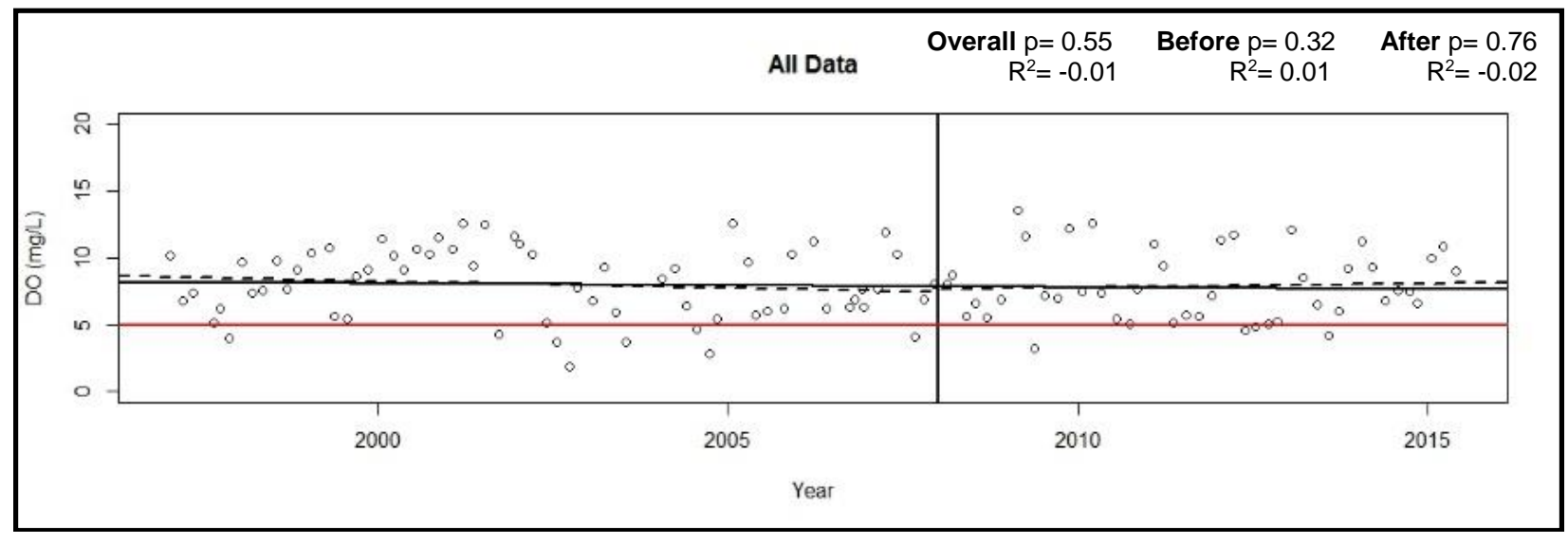




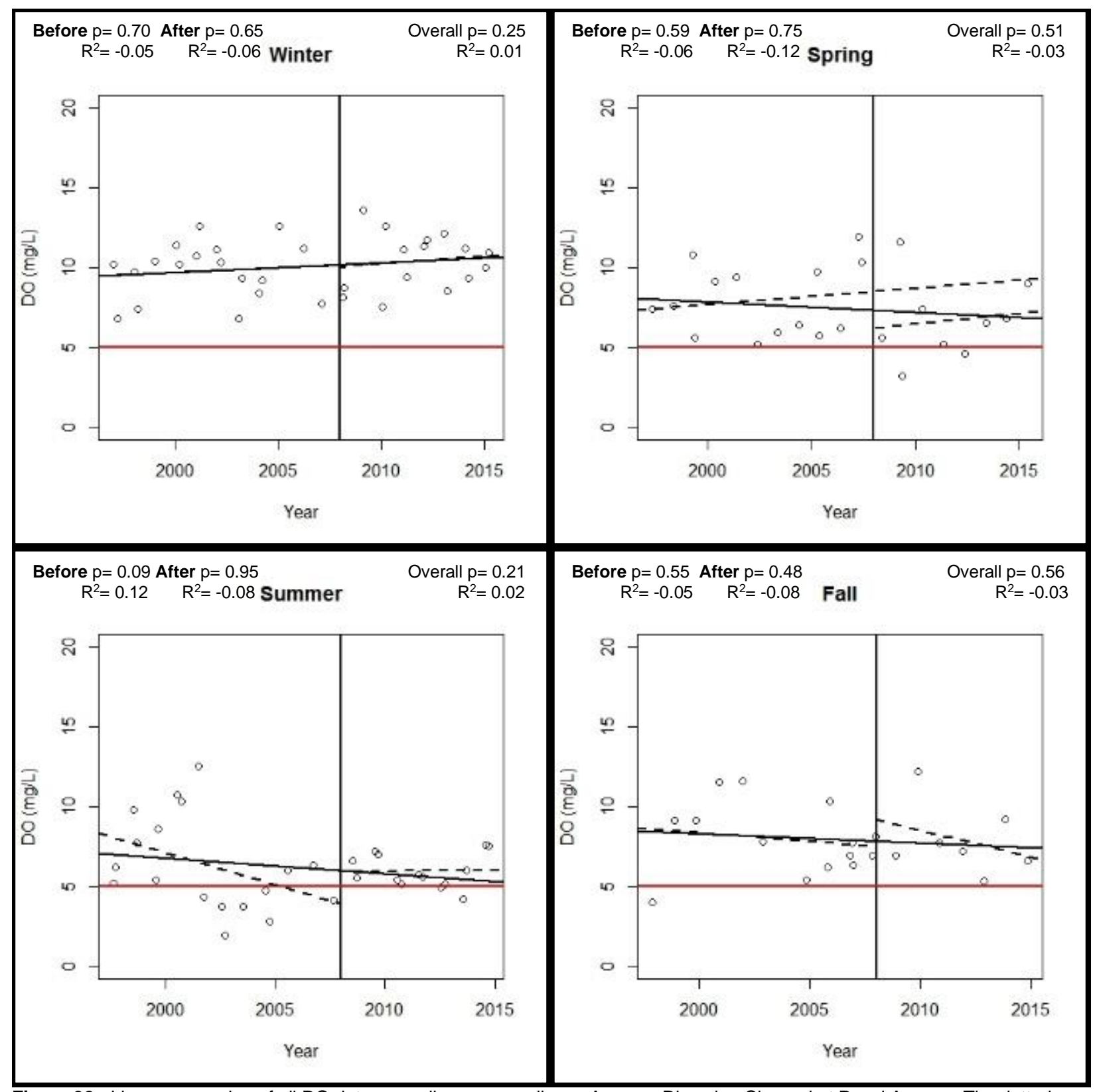

Figure 32: Linear regression of all DO data, as well as seasonally, on Amazon Diversion Channel at Royal Avenue. The dotted lines indicated linear regression before and/or after 2008. The solid black line indicates the overall linear regression. The horizontal red line is the State single sample exceedance level $(5.0 \mathrm{mg} / \mathrm{L})$.

\section{A-3 Drain at Terry Street}

A-3 Drain at Terry Street exceeded the single sample criterion for DO during the summer and fall before and after 2008 (Figure 33, Appendix A: Figure 17, Table 17). Samples collected during the spring and winter did not exceed State single sample criterion. The percentage of exceedances during the summer increased $31 \%$ during the summer and $19 \%$ during the fall. Single sample exceedances on A-3 Drain at Terry Street were significantly seasonally different after 2008 but not before 2008 (Appendix B: Table 3 and 4). The allocated percent reduction in nutrient concentration, BOD concentration, and SOD concentration (40\%) has not been met since 2008; ammonia has decreased by $24 \%$, nitrate/nitrite as $\mathrm{N}$ has decreased by $16 \%$, total phosphorus has decreased by $32 \%$, TSS has decreased by $47 \%$, and BOD has decreased by 
35\% (Appendix F: tables 40, 42, 44, 45, and 46). The average temperature before and after 2008 has decreased by $23 \%$ changed (Appendix F: Table 41).

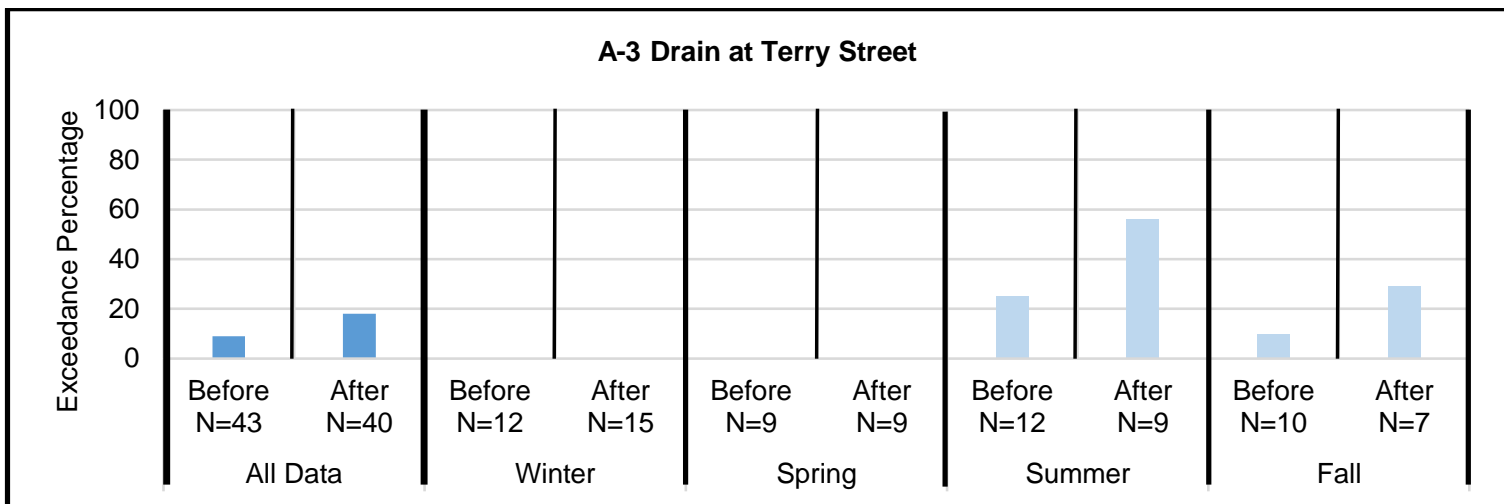

Figure 33: Bar charts of the percentage of single sample DO criterion exceedance before and after 2008 on A-3 Drain at Terry Street. The charts are split seasonally, as well as all data.

A-3 Drain was found to have a significant change in the means during the summer before and after 2008 (Appendix C: Table 17). Linear regression analysis found no data sets to have a significant trend (Figure 34, Appendix D: Table 17). There were no significant changes found in the trends of any data set. The high variability among samples along with minimal seasonal/yearly data collection caused forecasting DO concentration through auto ARIMA modeling to be unreliable. The model forecasted no change in the mean; however, the mean is forecasted to be above the single sample criterion. The lower $95 \%$ confidence interval is forecasted to exceed the single sample criterion year round (Appendix E: Figure 10).

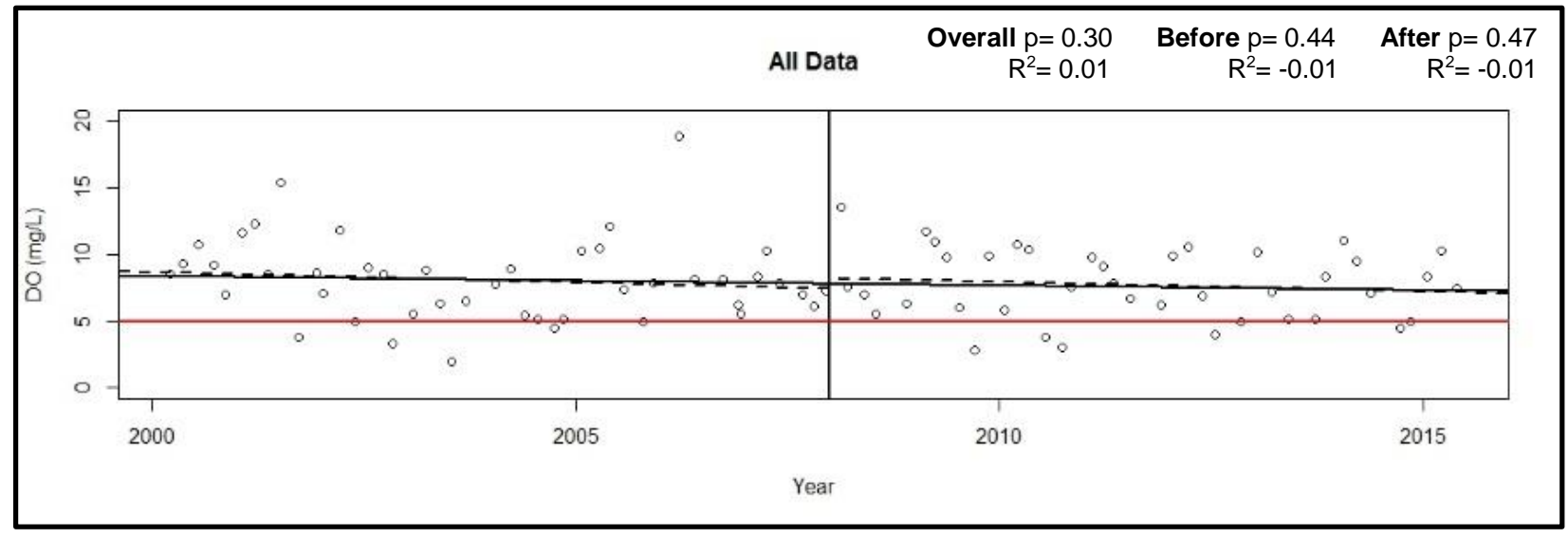




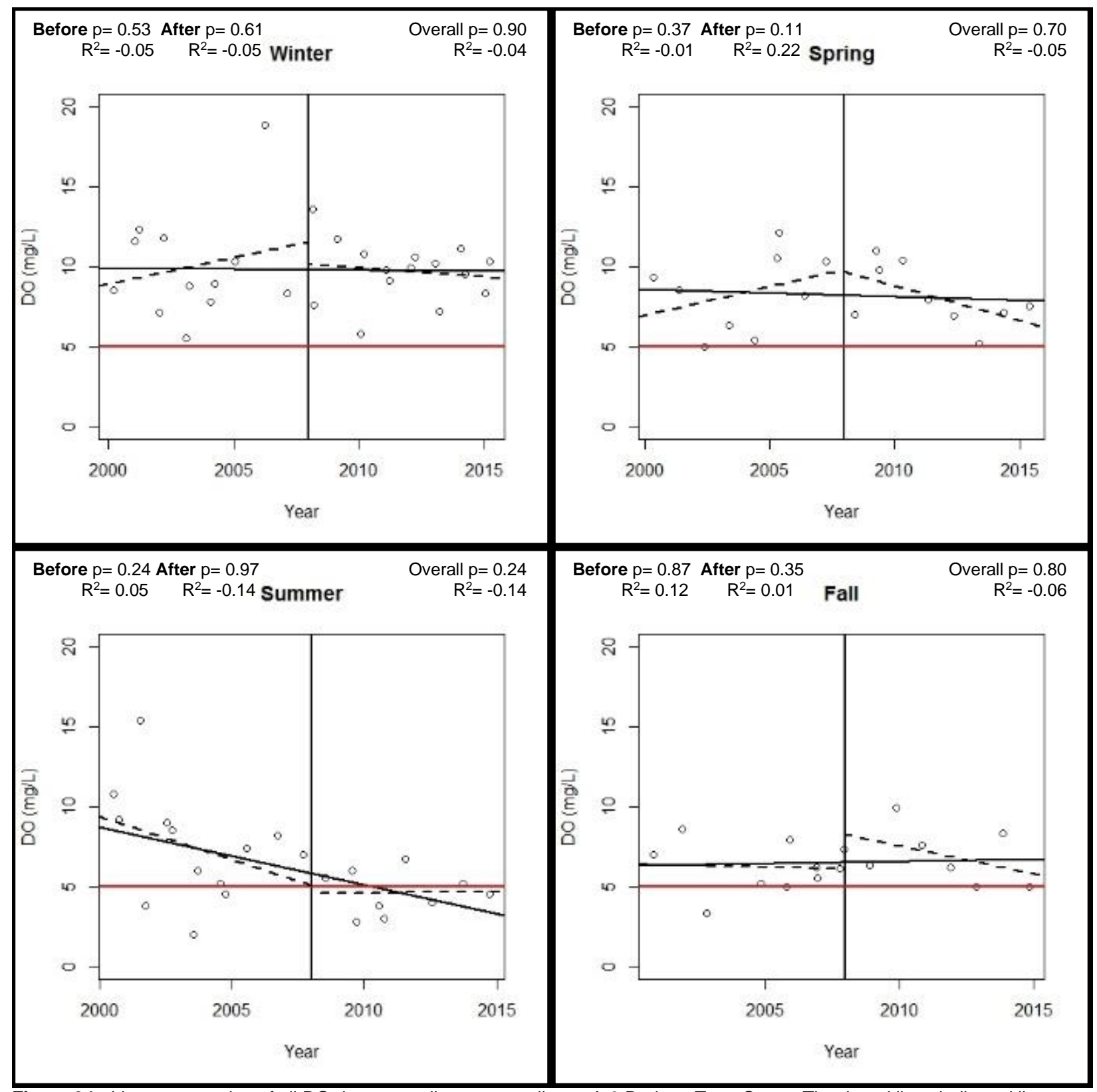

Figure 34: Linear regression of all DO data, as well as seasonally, on A-3 Drain at Terry Street. The dotted lines indicated linear regression before and/or after 2008. The solid black line indicates the overall linear regression. The horizontal red line is the State single sample exceedance level $(5.0 \mathrm{mg} / \mathrm{L})$.

\section{Lower Amazon}

\section{Amazon Creek at RM 5.82}

Amazon Creek at RM 5.82 was not sampled before 2008. After 2008, it was sampled a total of six times for DO concentration and did not exceed the single sample criterion (Figure 35, Appendix A: Figure 18, Table 18). RM 5.82 could not be tested for seasonal dependence due to the lack of seasonal data (Appendix B: Table 3 and 4). The lack of data did not allow sufficient analysis towards the allocated percent reduction. 


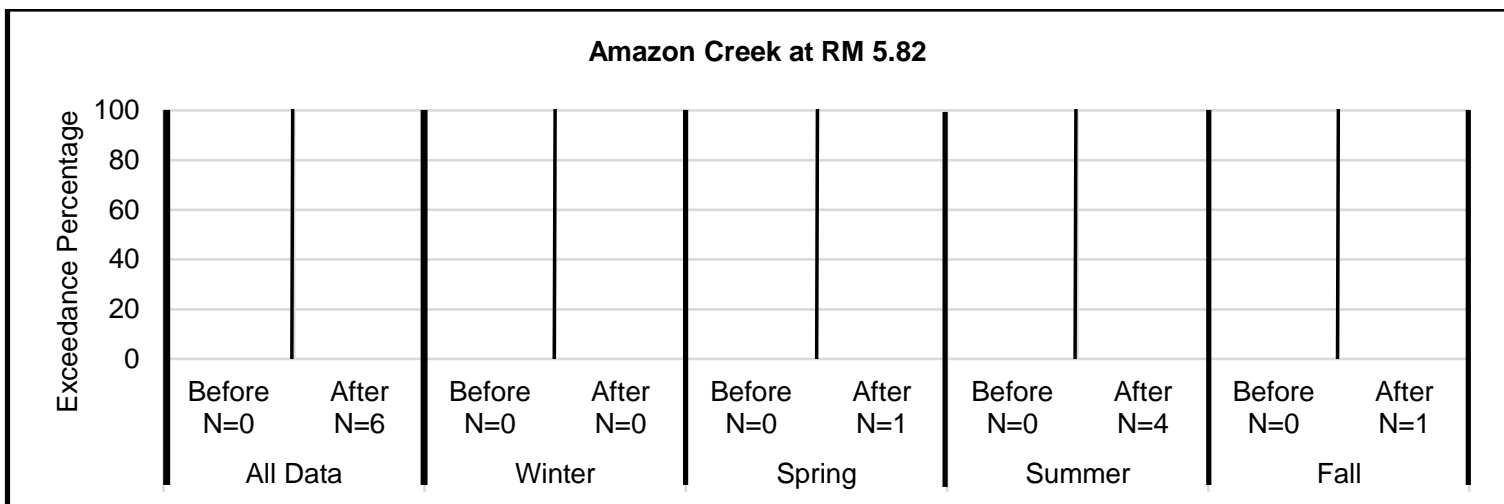

Figure 35: Bar charts of the percentage of single sample DO criterion exceedance before and after 2008 on Amazon Creek at RM 5.82. The charts are split seasonally, as well as all data.

RM 5.82 could not be tested for possible changes in the means for any data set (Appendix C: Table 18). Linear regression analysis found the summer data to have a significantly increasing trend (Figure 36, Appendix D: Table 18). RM 5.82 could not be tested for changes in trends before and after 2008 due to no data before 2008. The lack of seasonal/yearly data does not allow auto ARIMA.

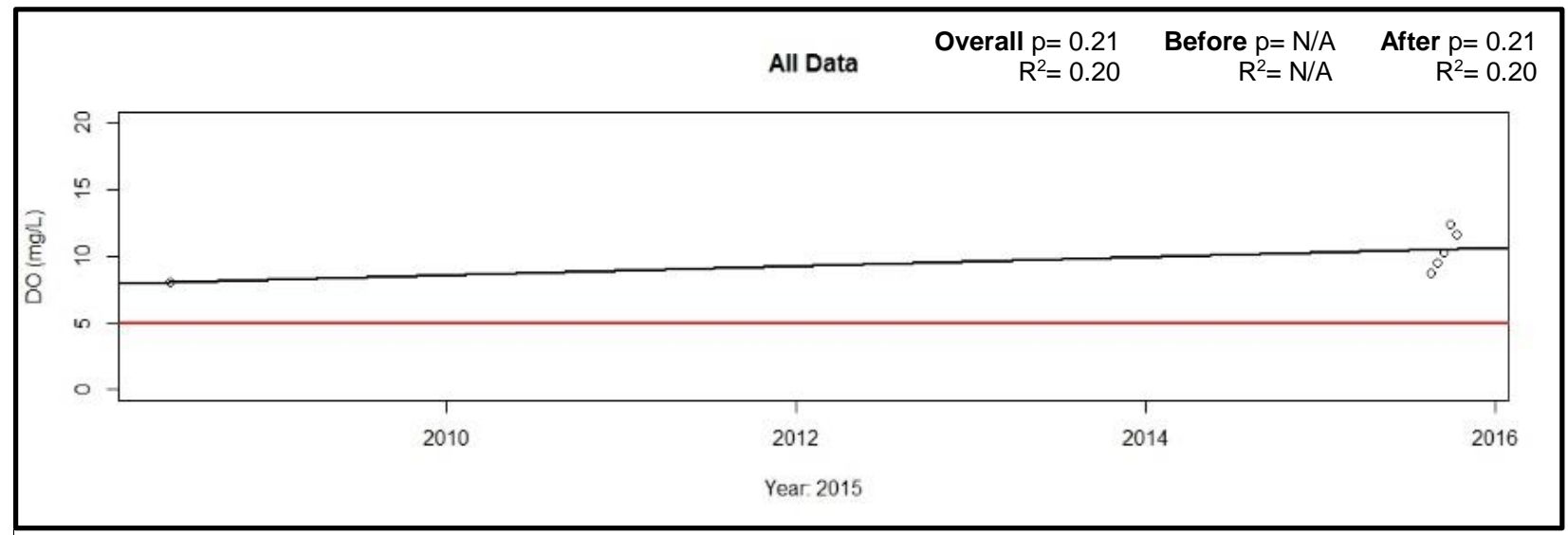

Figure 36: Linear regression of all DO data on Amazon Creek at RM 5.82. The dotted lines indicated linear regression before and/or after 2008. The solid black line indicates the overall linear regression. The horizontal red line is the State single sample exceedance level $(5.0 \mathrm{mg} / \mathrm{L})$.

\section{Amazon Creek at High Pass Road}

Amazon Creek at High Pass Road did not exceed State single sample criterion for DO before or after 2008 (Figure 37, Appendix A: Figure 19, Table 19). Single sample exceedances at High Pass Road were not significantly seasonally different (Appendix B: Table 3 and 4). The allocated percent reduction in nutrient concentration for BOD and SOD (40\%) has not been met since 2008; there was no before or after data to compare for ammonia, nitrate/nitrite as N, TSS, and BOD (Appendix F). The average temperature decreased by 15\% after 2008 (Appendix F: Table 48). Total phosphorus did not change, and temperature decreased by $2 \%$ (Appendix F: Table 49). However, the lack of data did not allow sufficient analysis towards the allocated percent reduction. 


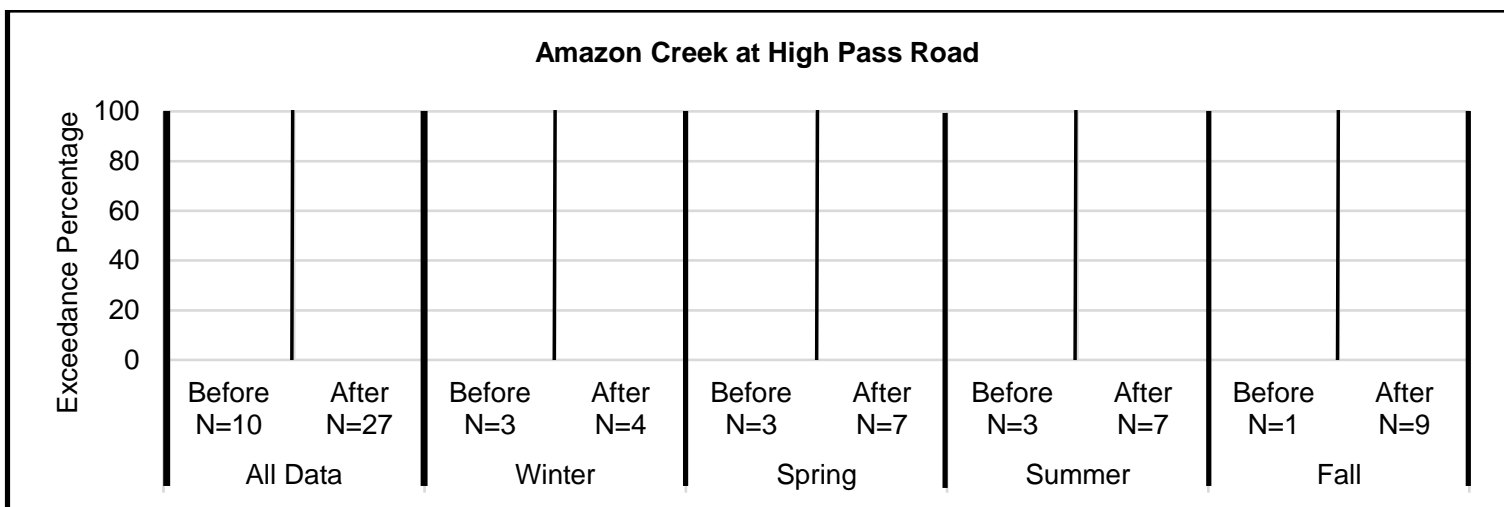

Figure 37: Bar charts of the percentage of single sample DO criterion exceedance before and after 2008 on Amazon Creek at High Pass Road. The charts are split seasonally, as well as all data.

High Pass Road was not found to have a significant change in the means for any data set (Appendix C: Table 19). The overall data set was not tested for a significant change because of only 1 sample collection during the fall before 2008. Linear regression analysis did not find any significant trends in any of the data sets (Figure 38, Appendix D: Table 19). There were no significant differences in the trends of any data sets. The lack of seasonal/yearly data did not allow ARIMA modeling.

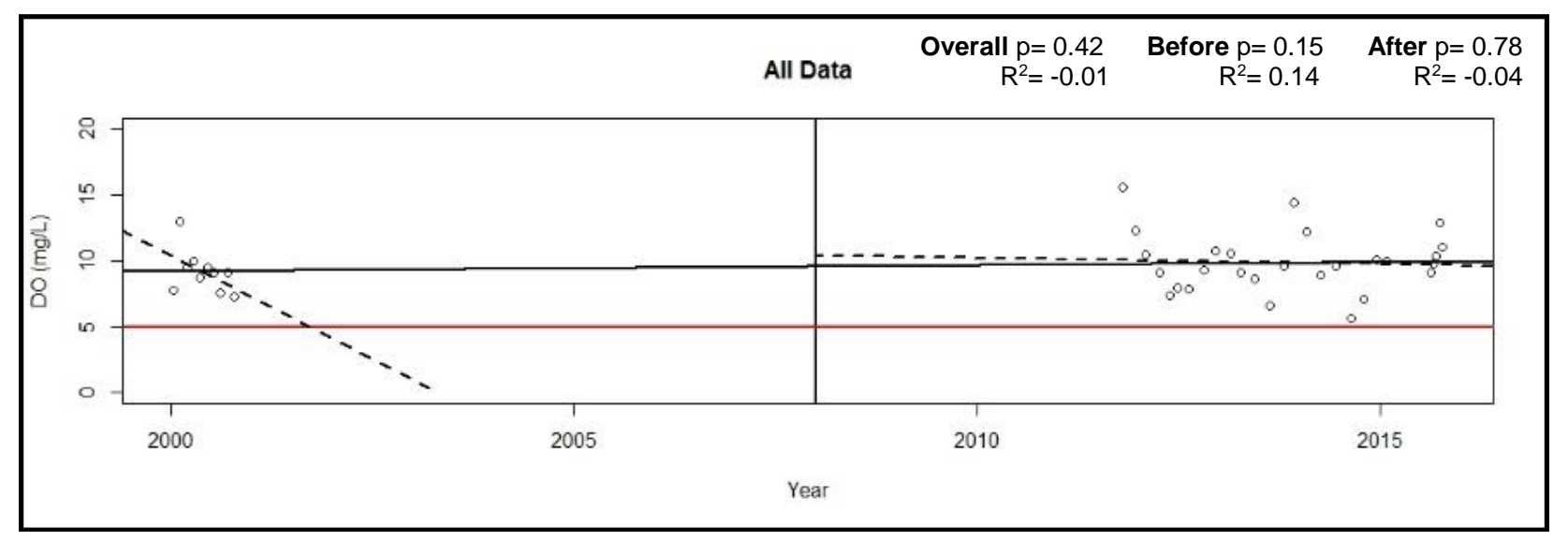




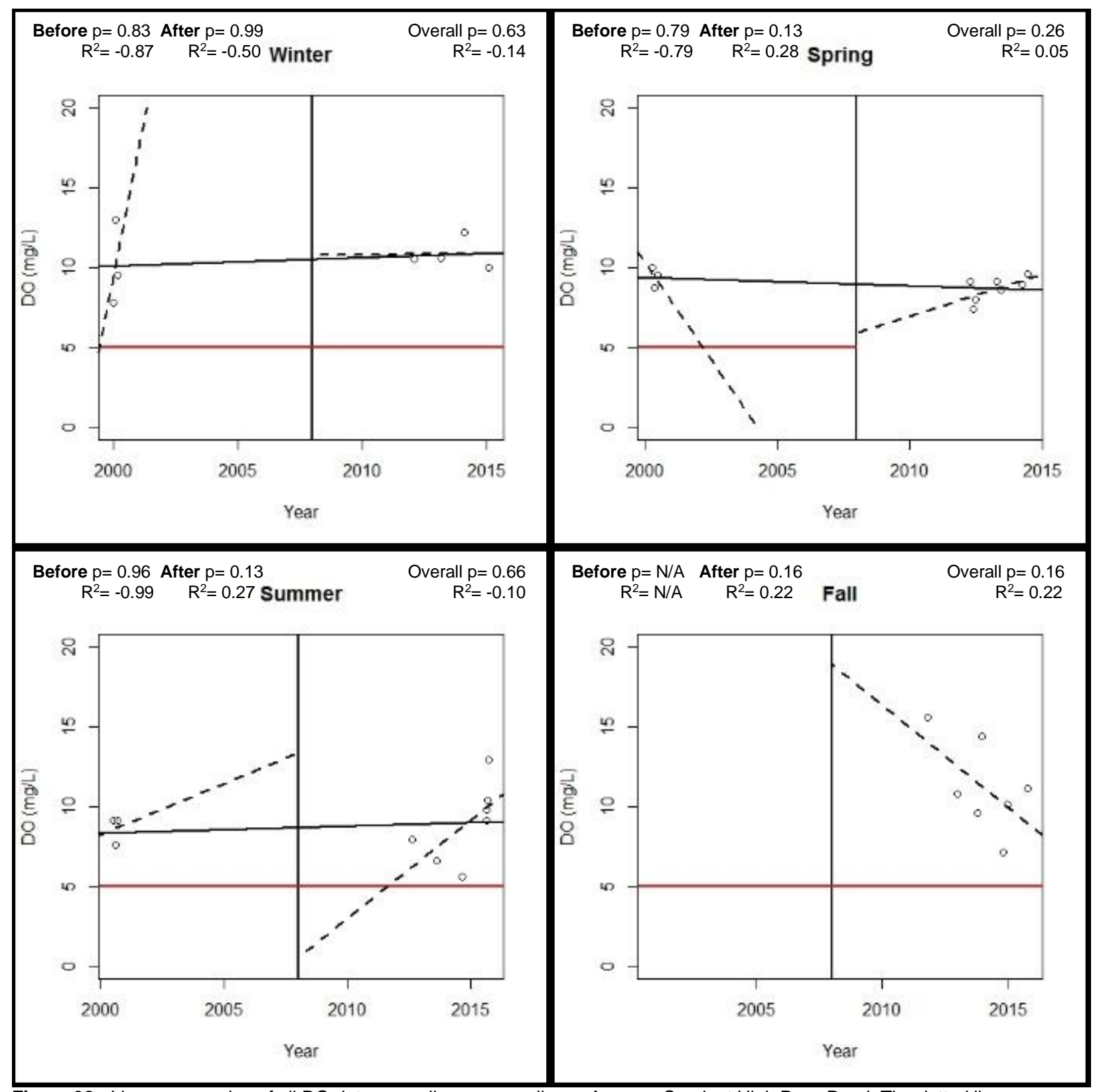

Figure 38: Linear regression of all DO data, as well as seasonally, on Amazon Creek at High Pass Road. The dotted lines indicated linear regression before and/or after 2008. The solid black line indicates the overall linear regression. The horizontal red line is the State single sample exceedance level $(5.0 \mathrm{mg} / \mathrm{L})$.

\section{Coyote Creek}

\section{Coyote Creek at Hamm Road}

Coyote Creek at Hamm Road did not exceed single sample criterion for DO before 2008; but exceeded State criterion once during the summer of 2015 (Figure 39, Appendix A Figure 20, Table 20). Coyote Creek at Hamm Road had not been sampled since the summer of 2001 until the summer of 2015. Single sample exceedance criterion at Hamm Road was not seasonally significant before 2008 and could not be tested for seasonal differences after 2008 (Appendix B: Table 3 and 4). The lack of data did not allow sufficient analysis for the allocated percent reduction. 


\section{Coyote Creek at Hamm Road}

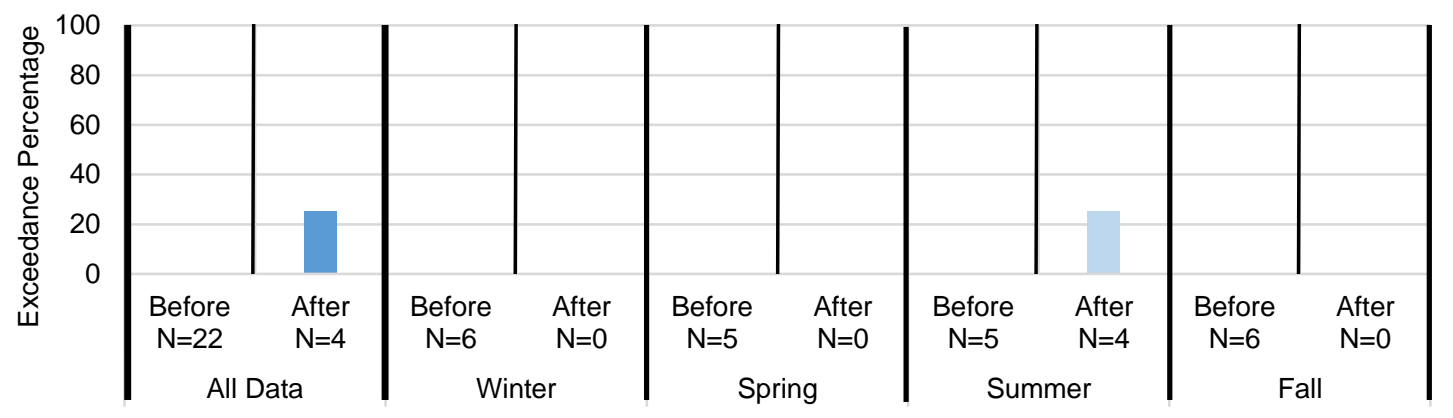

Figure 39: Bar charts of the percentage of single sample DO criterion exceedance before and after 2008 on Coyote Creek at Hamm Road. The charts are split seasonally, as well as all data.

Hamm Road had a significant difference in means during the summer (Appendix C: Table 20). No other season could be tested due to lack of sampling after 2008. Linear regression analysis found the summer after 2008 to have a significantly increasing trend (Figure 40, Appendix D: Table 20). However, there was no significant difference found for changes in trend during the summer before and after 2008. No other season could be tested due to the absence of data after 2008. The lack of seasonal/yearly data does not allow ARIMA modeling.

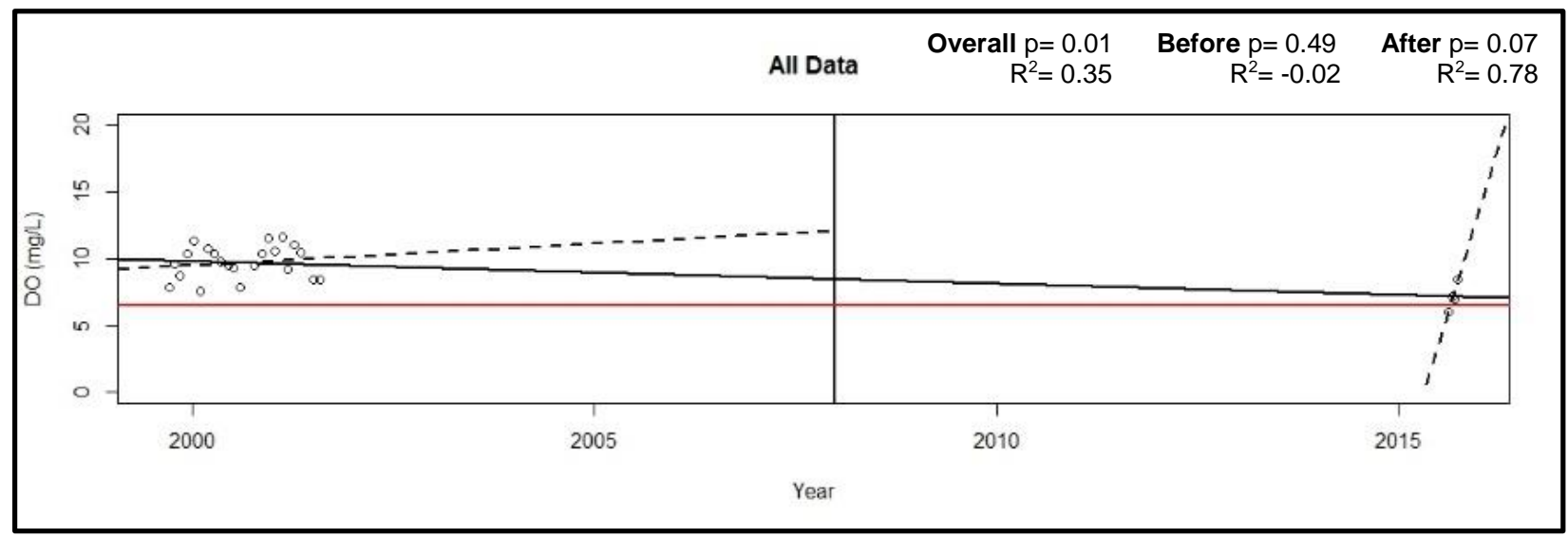




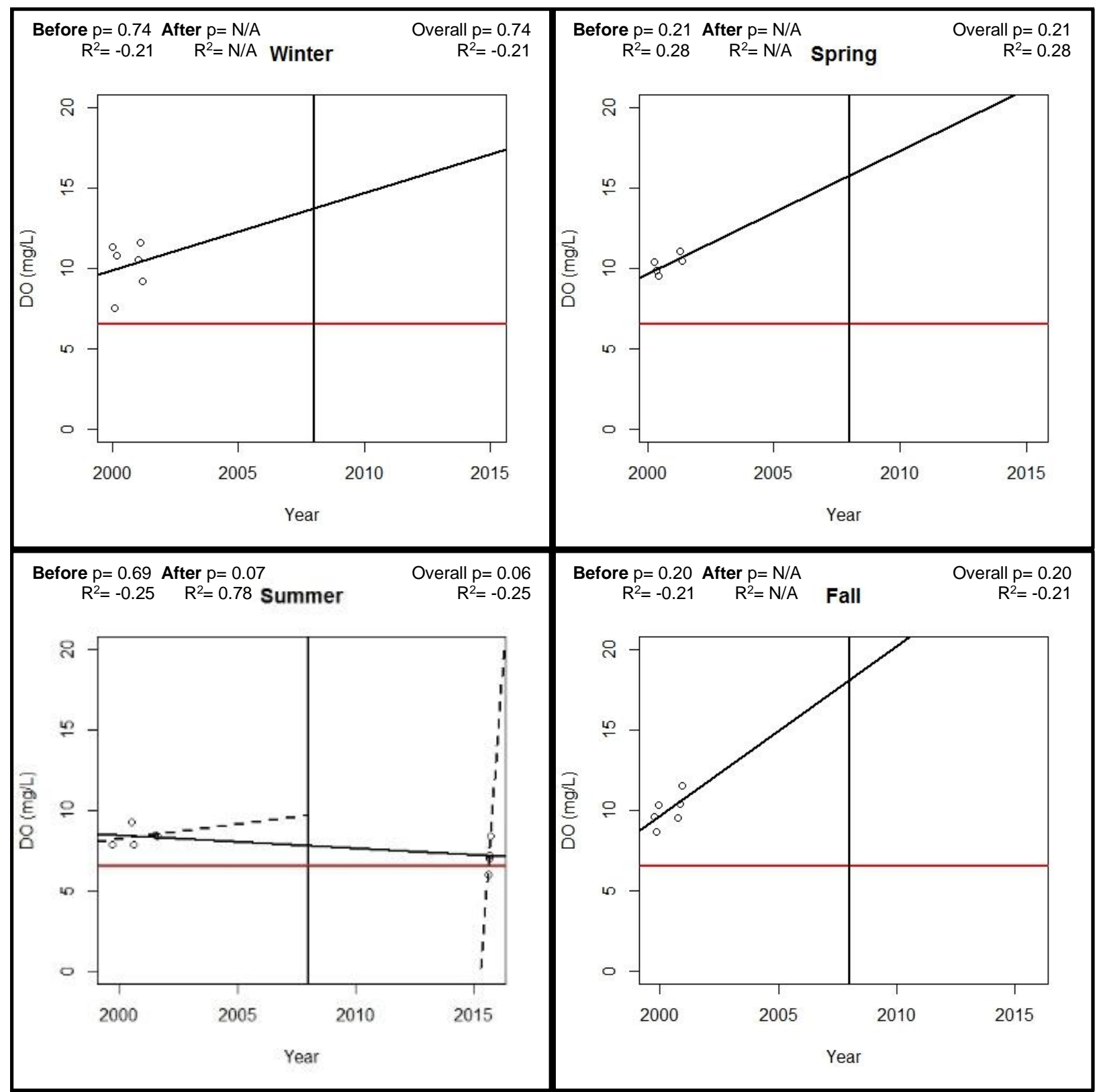

Figure 40: Linear regression of all DO data, as well as seasonally, on Coyote Creek at Hamm Road. The dotted lines indicated linear regression before and/or after 2008. The solid black line indicates the overall linear regression. The horizontal red line is the State single sample exceedance level $(6.5 \mathrm{mg} / \mathrm{L})$.

\section{Coyote Creek at Powell Road}

Coyote Creek at Powell Road exceeded the State single sample criterion for DO during the summer before and after 2008 (Figure 41, Appendix A: Figure 21, Table 21). Powell Road had not been sampled since the summer of 2001 until the summer of 2015. Single sample exceedance criterion at Powell Road was found to be seasonally different before 2008 but could not be tested for seasonal differences after 2008 (Appendix B: Table 3 and 4). The lack of data did not allow sufficient analysis of the allocated percent reduction. 


\section{Coyote Creek at Powell Road}

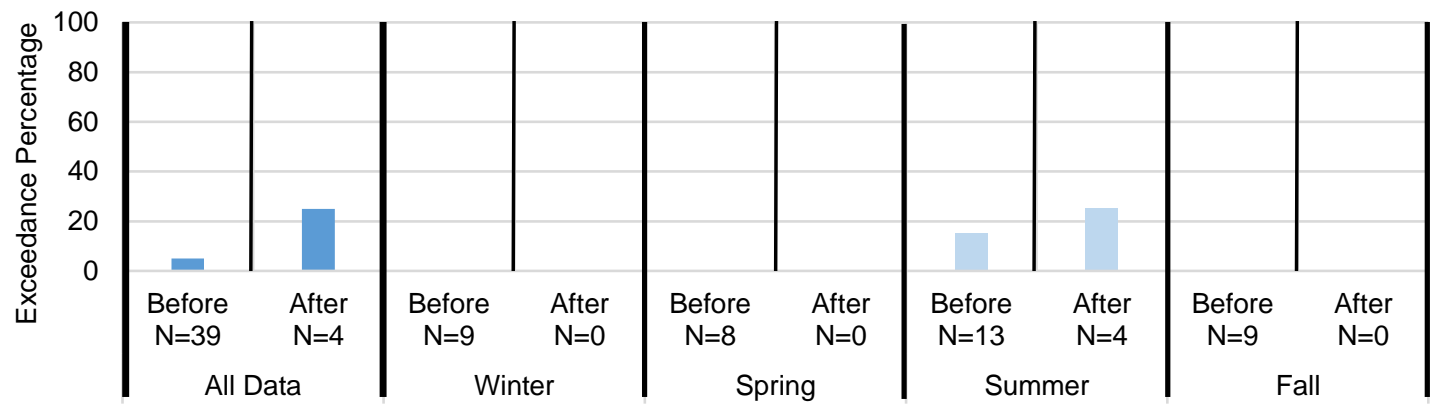

Figure 41: Bar charts of the percentage of single sample DO criterion exceedance before and after 2008 on Coyote Creek at Powell Road. The charts are split seasonally, as well as all data.

Powell Road had a significant difference in means during the summer (Appendix C: Table 21). No other season could be tested due to lack of sampling after 2008. Linear regression analysis did not find significant trends for any dataset (Figure 42, Appendix D: Table 21). There were no significant differences in trends during the summer before and after 2008. No other season could be tested due to the absence of data after 2008. The lack of seasonal/yearly data did not allow ARIMA modeling.

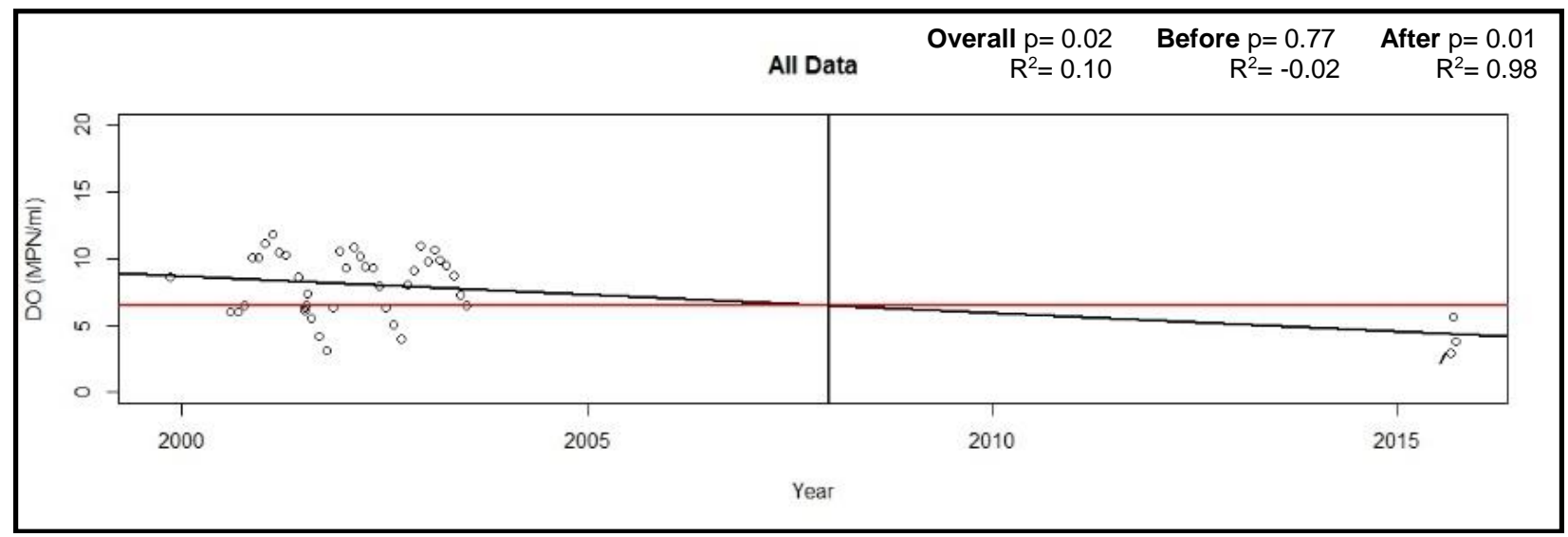




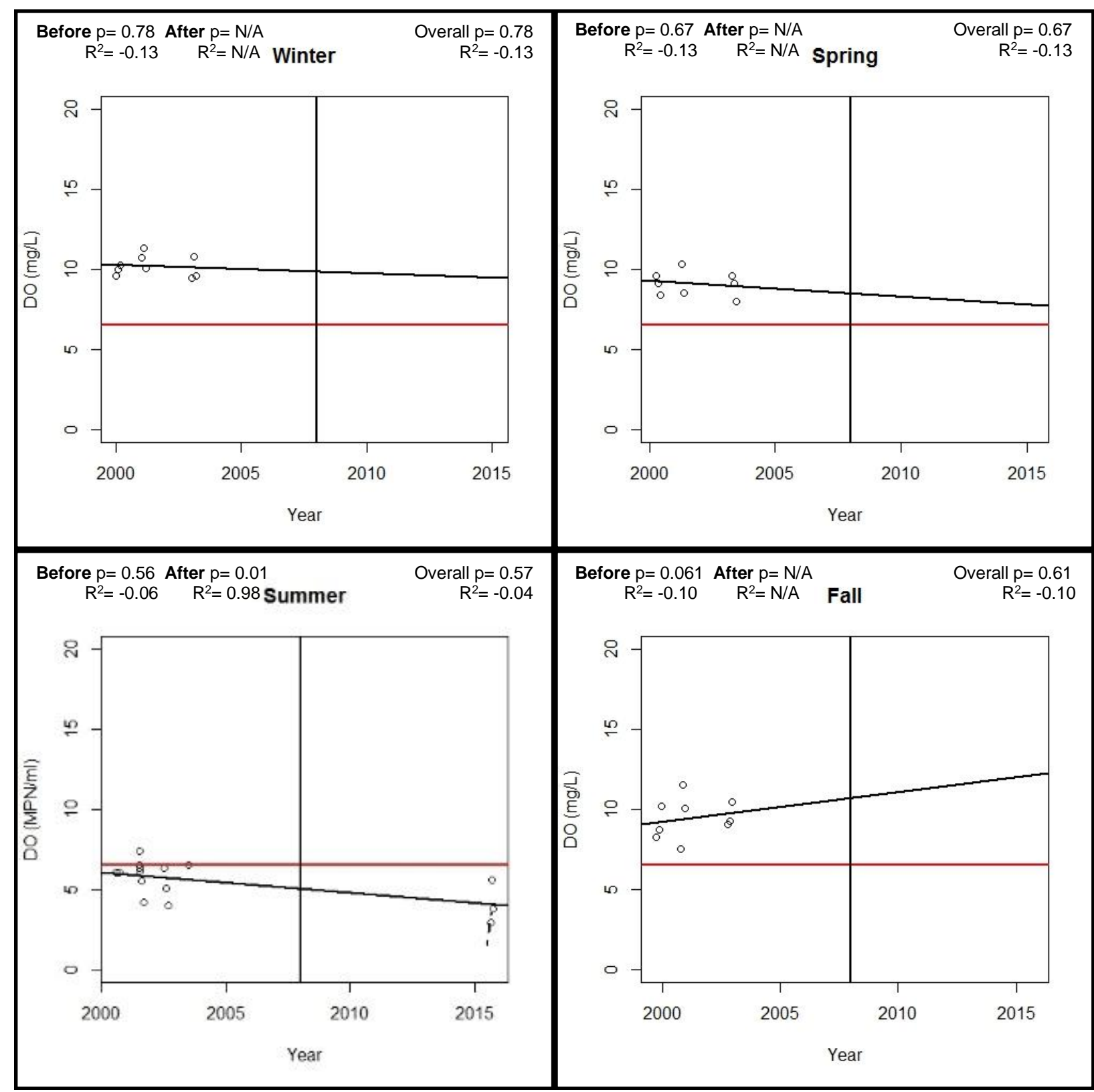

Figure 42: Linear regression of all DO data, as well as seasonally, on Coyote Creek at Powell Road. The dotted lines indicated linear regression before and/or after 2008. The solid black line indicates the overall linear regression. The horizontal red line is the State single sample exceedance level $(6.5 \mathrm{mg} / \mathrm{L})$.

\section{Coyote Creek at Petzold Road}

Coyote Creek at Petzold Road exceeded State single sample criterion for DO during the summer before and after 2008 (Figure 43, Appendix A: Figure 22, Table 22). Petzold Road had not been sampled since the summer of 2001 until the summer of 2015. Single sample exceedances at Petzold Road were not seasonally different before 2008 and could not be tested for seasonal dependence after 2008 (Appendix B: Table 3 and 4). The lack of data did not allow sufficient analysis of the allocated percent reduction. 


\section{Coyote Creek at Petzold Road}

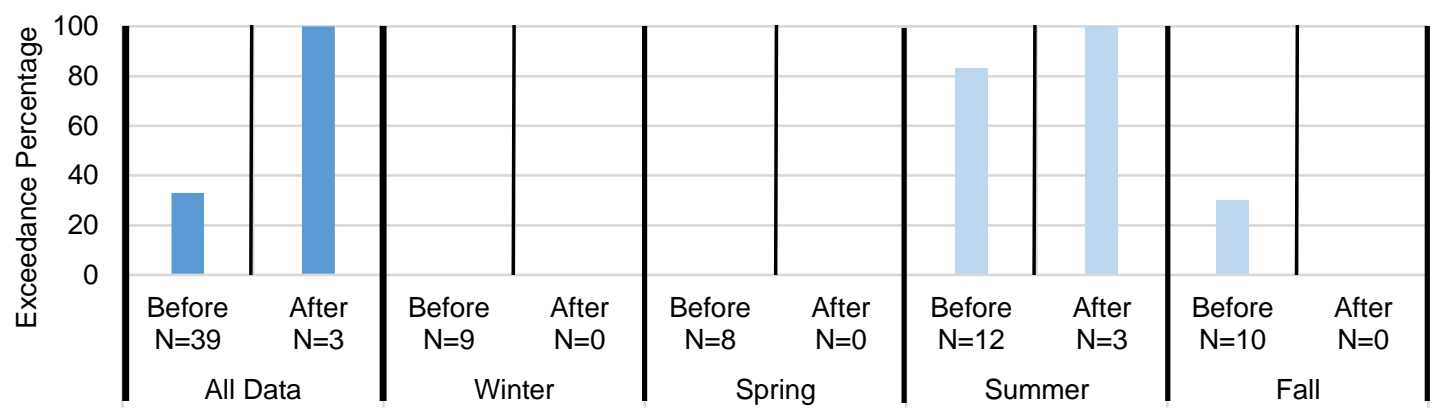

Figure 43: Bar charts of the percentage of single sample DO criterion exceedance before and after 2008 on Coyote Creek at Petzold Road. The charts are split seasonally, as well as all data.

Petzold Road did not have significant differences in means during the summer (Appendix C: Table 22). No other season could be tested due to lack of sampling after 2008. Linear regression analysis found the summer after 2008 to have a significantly increasing trend (Figure 44, Appendix D: Table 22). There was no significant difference in trend during the summer before and after 2008. No other season could be tested due to the lack of data after 2008. The lack of seasonal/yearly data did not allow ARIMA modeling.

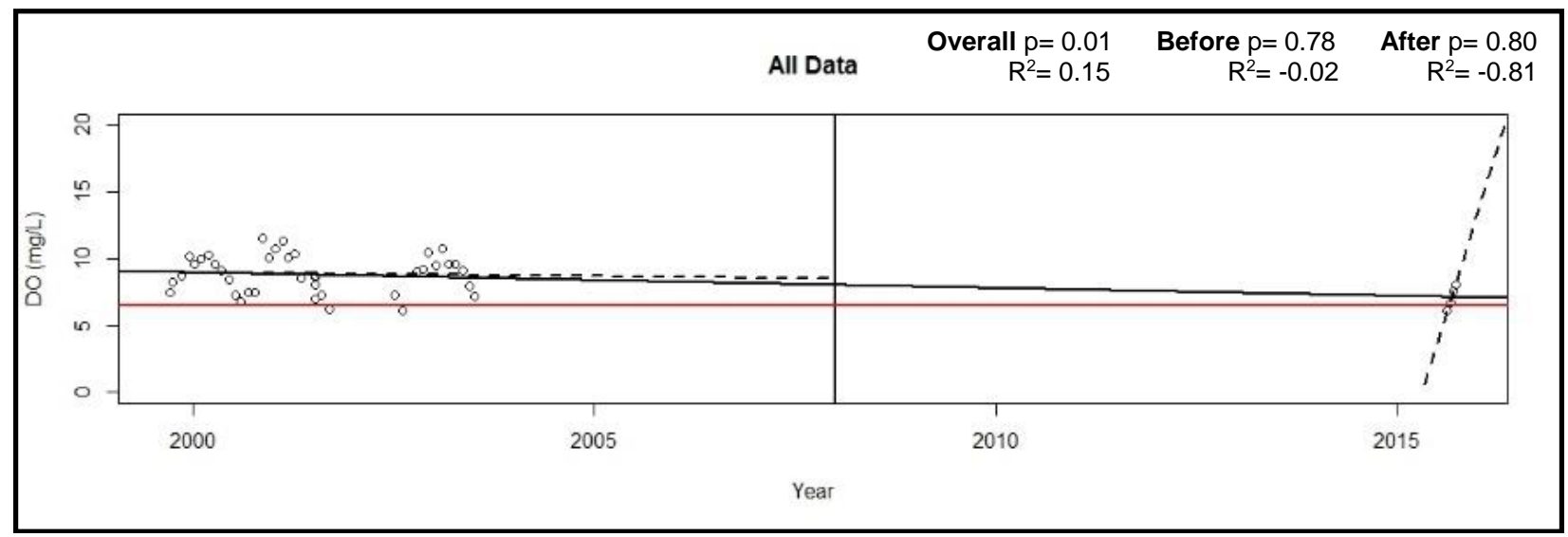




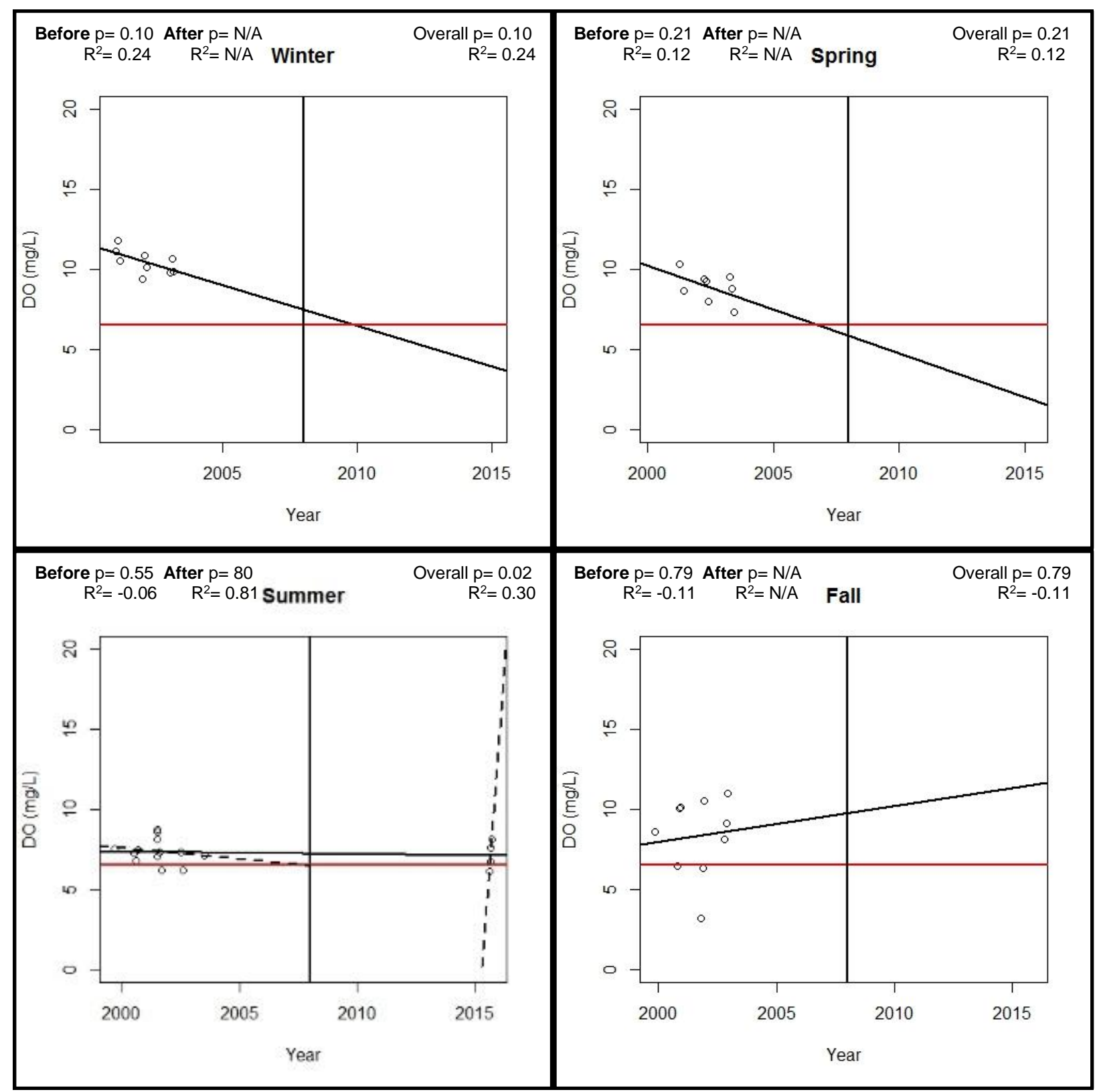

Figure 44: Linear regression of all DO data, as well as seasonally, on Coyote Creek at Petzold Road. The dotted lines indicated linear regression before and/or after 2008. The solid black line indicates the overall linear regression. The horizontal red line is the State single sample exceedance level $(6.5 \mathrm{mg} / \mathrm{L})$.

\section{Discussion}

There is a need to clearly define the role of DMA monitoring approaches if status and trend analyses are to efficiently and effectively assess progress towards meeting TMDL wasteload and load allocations. Analysis of the effectiveness of DMAs TMDL implementation plan objectives and trend analysis could not be assessed due to sparse data sets. The lack of data in the Amazon Creek and Coyote Creeks watersheds could only be used to assess the current status of pollutant concentration levels. Trend analysis was hindered for both overall data sets as well as seasonal data sets because sparse samples were collected within the same climatic and environmental conditions over time. In order to understand the effectiveness of DMAs 
TMDL implementation plan objectives quantitatively, monitoring approaches in whole (amount of sample stations and yearly routine collection amount) needs to be improved upon. Design of these monitoring approaches should not only include where, what, and when sampling occurs, yet a definitive conclusion to why those approaches were chosen and how they will influence water quality must be understood.

Box plots and tabulations of the percentages of exceedances were the most useful for products examining E. coli and DO concentrations before and after TMDL implementation began in 2008. However, interpretation of these analyses was still complex. Based on available data, Upper and Lower Amazon Creeks remain impaired from elevated bacteria concentrations. Based on a sparse dataset, evidence suggests that bacteria levels in Coyote Creek have decreased above its confluence with Spencer Creek. Upper Amazon Creek and Coyote Creek continue to be impaired for DO while DO concentrations in Lower Amazon have increased. However, the use of grab samples usually does not allow for adequate analyses of DO dynamics or moving averages that are part of DO standards applicable in these streams. Pollutant reduction allocations have been met for $E$. coli concentrations in the A-3 Drain; yet $E$. coli concentrations remain in exceedance of the single sample State criterion. The allocated reduction percentage was difficult to analyze due to differences in seasonal bacteria concentration. Bacteria concentration reduced by $48 \%$ overall on the A-3 Drain at Terry Street, on average, when comparing data collected before and after 2008, but when comparing data collected after December of 2002 until present, during late October through the end of December, E. coli concentration decreased by only $3 \%$.

The current protocol for monitoring bacteria and DO in these streams (one grab sample on average per season) hinders the ability to detect of water quality standard exceedances. The sample stations and seasons which show exceedance or are near exceedance can only be assumed to exceed the single sample and, possibly, the 7-day criterion because they likely do not capture the lowest level of DO concentration or the highest $E$. coli concentration on the day of sampling. Sparse grab samples only convey limited instantaneous measures, which makes detailed assessments of seasonal or annual trends in water quality problematic. DO concentration is even more variable based on the time of day, recent precipitation events, temperature variability, and/or nutrient concentration.

Of the 91 trends analyzed through linear regression for increasing or decreasing $E$. coli and DO concentrations before and after 2008 (182 combined), only 15 were found to be significant, seven for $E$. coli and eight for DO. Willow Creek was the only sample station found to have a significant trend (increasing) for the entire data set for DO concentration. None were found for E. coli concentrations. However, Willow Creek was not sampled continuously during the summer due to low flows. The lack of summer sampling biased the overall results for both $E$. coli and DO concentration because summer is typically when bacterial concentrations are greatest and DO concentrations are lowest. Sparse sampling resulted in high variability within each dataset, creating low $\mathrm{R}^{2}$ values $(<0.10)$, high residual standard errors, and ultimately lack of ecologically-meaningful trends.

Understanding how specific implementation activities in the Amazon Creek and Coyote Creek watersheds have or are helping pollutant reductions could not be achieved based on available data. Sparse collection of water quality data led to uncertain status and trend analyses. Coyote Creek had not been tested for TMDL-related water quality parameters between 2001 and the sample collection conducted by ODEQ in the summer of 2015. Data obtained in the 2015 collection only informed current status of water quality. Ultimately, identifying TMDL implementation activities that influenced DO and bacteria levels could not be achieved purely from status and trend analyses. 
Restoration and mitigation measures do not usually result in instantaneous remediation of water quality and fail to meet expectations for water quality improvement because of lag time (Meals, Dressing, and Davenport 2009). Even when management changes are well-designed and fully implemented, water quality monitoring efforts may not show definitive results if the monitoring period, program design, and sampling frequency are not sufficient to address the lag between treatment and response (Meals, Dressing, and Davenport 2009). Important processes influencing lag time include hydrology, vegetation growth, transport rate and path, hydraulic residence time, pollutant sorption properties, and ecosystem linkages (Meals, Dressing, and Davenport 2009). The magnitude of lag times for specific processes is highly site and pollutant specific, but may range from months to years for relatively short-lived contaminants such as indicator bacteria or years to decades for excessive nutrient loads (Meals, Dressing, and Davenport 2009).

In both Amazon Creek and Coyote Creek, DMAs had been implementing water quality management actions for decades prior to TMDL issuance. This created difficulties in analyzing trends in water quality before and after the 2008 TMDL, because I was not able to separate and specifically examine particular management activities corresponding to the current water quality status. Furthermore, despite the long-term activities occurring throughout the watershed, there was little evidence of water quality improvements in DO and bacteria. These results cannot be assumed to be due to treatment failure, nor can they be assumed to result from a time lag. However, the lack of conclusive results can be specifically attributed to the lack of sampling stations and data collection. For example, trees planted or other mitigation measures implemented directly below $29^{\text {th }}$ Avenue on Amazon Creek cannot be specifically linked to changes in water quality data unless data are collected above, between, and below the restored areas. Analyses of data $11 \mathrm{~km}$ downstream can be confounded by environmental or anthropogenic factors downstream of the restoration location. This is probably the case for Coyote Creek as well, where data have not been consistently collected since 2003 . To determine if and how TMDL implementation activities meet or will meet load allocations, monitoring in Amazon Creek and Coyote Creek watersheds needs to be altered in a way in which allows the assessment of data in relation to specific water quality standards.

\section{Management Recommendations}

The water quality analyses for Amazon Creek and Coyote Creek led to the conclusion that describing the current status and trends of DO and bacteria levels in the Amazon Creek and Coyote Creek watersheds could not be sufficiently administered due to the lack of data, hindering the ability to understand pollutant sources, loading locations, and trends in water quality. Determining if TMDL implementation and other management activities had influenced DO and bacteria levels was also hindered due lack of data. In order to fully achieve these objectives, updates to state administrative rules for collecting water quality samples. Data collection and the number of sampling sites should be increased and better designed.

Data collection in the Upper Amazon dates back to 1997, and has been sampled on average of six times per year. The World Health Organization (WHO 1996) guide to water quality assessments recommends that more than 24 samples should be taken per year for no less than 10 years to perform trend analyses on streams and small rivers. WHO (1996) also recommended that to analyze or find potential loading sources, sample sites should be placed at plausible areas of potential pollutant loading, as well as above and below any major tributaries (WHO 1996). Adopting this approach, after remote sensing analysis, will better inform where or what types of implementation plans are needed within the area of concern. This approach will better facilitate where sampling stations are located because delineation of subregional watersheds will pinpoint where inflows are occurring, as well as allow DMAs to signify 
possible areas of loading (i.e. homeless camps, dog parks, stormwater conveyance systems inflows, public use areas, etc.).

An emerging and innovative technology is the use of continuous recording water-quality monitoring equipment (CR-WQME) (Maslia et al., 2005). Advantages of using CR-WQME include the ability to continuously record water-quality data at small time intervals, often 15 minutes or less (Maslia et al., 2005). In addition, the labor/time needed to conduct testing and laboratory analysis is greatly reduced. This technique still requires grab samples to be obtained to confirm sufficient calibration, yet the usage of continuous data obtained increases probability of understand and linking loading sources and areas (Maslia et al., 2005). This would specifically help in the Upper Amazon, where DO concentrations and temperature gradients during the spring and summer exhibit variable results, due to current grab sampling procedures. Continuous data also allow the evaluation of state water quality standards that have moving average components, such as the DO standard (OAR 340-041-0016).

Within the Amazon and Coyote Creek watersheds, the ways in which bacteria loading sources are determined should be revised. In the Upper Amazon, where E. coli concentrations are highest near the headwaters, current monitoring approaches can only be used to link possible areas above where loading could occur. Increasing collections sites throughout the stream segment would increase the ability to determine locations of influential loading sources.

Currently, the distance between the furthest upstream collection site on Amazon Creek (29) Avenue) and the next downstream collection site (Railroad Crossing) is seven miles. This distance does not allow sufficient analyses of contaminant load trends or sources. I recommend that samples be collected once per month for a minimum of three years at two to three miles intervals in order to obtain sufficient data for status and trend analyses. To improve accuracy of current $E$. coli status, 5 grab samples within a 30 day period during the middle of each season (February (winter), May (spring), August (summer), and November (fall)) should be collected. If this is not possible here and elsewhere, the state should consider reassessing state exceedance criteria (i.e., 7-day and 30-day exceedances (OAR 340-041-0009(1)(a)(A:B)). Lack of data sampling requirements for the 7-day or 30-day state exceedance criteria makes it impossible to tell if the current sampling procedure (grab samples) is biased toward high or low concentrations. Also, neither Amazon Creek nor Coyote Creek had flow measurements. Without flow measurements, agencies cannot easily assess where loading is occurring or whether certain areas are affected during high flow events or low flow events. Using seasonality as a surrogate for flow measurements does not adequately capture individual rain or system flush events.

It is recommended that the TMDL be reassessed to minimize any confusion about the allocated reduction percentages (specifically A-3 Drain). The percent reduction allocation was calculated from a small data set. Thus, TMDL allocations were set without a reasonable amount of seasonal and monthly data. The current amount of data in the Amazon Creek watershed allows determination of new reduction standards; but more data is needed for Coyote Creek to establish new reduction goals. The "phased TMDL" approach of using existing data, even though limited, to develop the TMDL when the State believes that the use of additional data or data based on better analytical techniques would likely increase the accuracy of the TMDL load reduction calculation merits development of its second phase TMDL. My recommendations would follow the path of adaptive implementation, where using new data and information can be used to reduce uncertainty and adjust implementation activities. However, under USEPA rules and regulations, if adaptive implementation activities reveal that a TMDL loading capacity needs to be changed, the revision would require EPA approval (EPA 1991). In most cases, adaptive implementation is not anticipated to lead to the re-opening of a TMDL, and is instead used to improve implementation strategies (EPA 1991). 
An example of a TMDL resulting in water quality improvements is the one for the Chesapeake Bay (CB). The CB TMDL is a multi-phase, multi-state/agency pollution reduction commitment which has shown beneficial outcomes. The multi-phase management approach was split into short-term reduction/attainment goals and long-term reduction/attainment goals (Chesapeake Bay 2015). This approach has allowed agencies to qualitatively assess immediate changes, with the understanding that some changes will take five to twenty or more years to become fully functional. The CB TMDL implementation plans required DMAs to describe timelines of attainment to each implementation activity. Emulating this requirement would help ODEQ as well as DMAs assess progress in meeting objectives and identify additional work needed to achieve goals. A major issue with DMA implementation plans for Amazon and Coyote Creeks is that they do not provide information on the expected percent reductions that will result from specific actions. The implementation plans provided by the DMAs provide timelines for implementing the measureable milestones; yet how these milestones are expected to reduce pollutants is key to understanding if the implementation activities are or will be successful. In order for this to occur, DMAs should provide a quantitative description on how and what will occur from planned activities.

Modeling uncertainties in the CB TMDL were also a concern. To improve upon the statistical modeling, sampling stations were increased and the time period between sampling was reduced, ultimately leading to a better understanding of how BMPs and implementation activities influenced pollutant loading (Chesapeake Bay 2015). The CB TMDL team is currently working on a report such as this to assess TMDL allocations status and trends, determine if implementation activities can be linked to changing water quality data, and assess for adaptive management.

The World Health Organization has stated that the usefulness of the information obtained from monitoring is severely limited unless administrative and legal frameworks (with institutional and financial commitments) exist at local, regional, or international levels (WHO 1996). At Coyote Creek, where land is primarily private or managed by ODF and ODA, monitoring procedures should follow recommendations stated above. According to OAR 340-042-0080(3), performing monitoring and providing evidence of compliance is not required for land managed by ODF or ODA. However, in order to determine if Coyote Creek is meeting or exceeding criterion and/or load allocations, data must be collected. Furthermore, guidelines to and for ODA and ODF managed lands and/or neighboring lands needs to be reassessed and restructured to require the agencies to perform and implement watershed specific WQMPs for all 303(d) listed streams in their governing lands.

All DMAs were willing to implement activities that would improve water quality. However, funding for these activities has been limited. As per requirements for implementation plans, DMAs must identify primary concerns for the 303(d) listings, identify management strategies which will achieve load allocations and reduce pollutant loading, provide a timeline for implementation and measureable milestones, provide for performance monitoring for periodic review and/or revision to their implementation plan, provide evidence of compliance, and other guidance provided in the WQMP. Completion of these steps requires adequate funding. The recommendations of this study for increased water quality sampling stations and frequency of sampling will add to the financial burden of the DMAs. In the CB, protection and restoration was signed as an executive order of the President in 2009, leading to considerable financial assistance (Chesapeake Bay 2015). However, similar to DMAs in Amazon and Coyote Creek, DMAs in the CB area still have impediments of financial capacity to oversee and implement management activities.

There are several funding avenues that DMAs can use to augment implementation activities. These include: Clean Water Act Section 319(h) funds provided to DMAs to implement their non- 
point source management programs (however, this funding was reduced by nearly $90 \%$ during 2015 as part of the Coastal Zone Act Reauthorization Amendment court settlement); Clean Water State Revolving Fund loan program that provides low-cost loans for planning, design, and construction of water pollution control activities; Oregon Watershed Enhancement Board grants funded through the Oregon Lottery that help restore/enhance streams, rivers, wetlands, and other natural areas to promote the Oregon Plan for salmon recovery; Environmental Quality Incentives Programs that provide financial and technical assistance to agricultural producers to improve soil, water and other natural resources on agricultural lands; and others. Although support from these sources is available, obtaining funding through these programs requires extensive work that cannot always be supported by the DMAs. Implementing these activities is also costly, as well as labor and technologically intensive.

As of 2008, the Eugene-Springfield urban growth boundary had a population of 240,000 , with the population for 2035 forecast to increase by 25\% (to 303,000) (USP 594 2011). This population growth not only means more people, but also more roads, buildings, and amenities built in order to accommodate this growth. Paired with climate change forecasts showing hotter, drier summers and more intense winter rain events, the riparian and vegetative habitat in and around both streams and water conveyance areas will soon be extremely important in moderating water temperatures and DO concentrations (USP 594 2011). The combination of the projected population growth and projected $1^{\circ} \mathrm{C}$ increase, on average, by 2035 will not only cause DMAs to examine capacity of existing water quality management systems to deal with these changes, but may also force them to develop new ways to manage water quality.

In conclusion, I recommend that in order to adequately assess the current status and trend and/or forecast future status and trends in water quality data, regulatory requirements for DMAs with 303(d) listed streams should be expand and modified. Doing so will enhance the ability of ODEQ, DMAs, and other interested parties to assess water quality status and trends. Grab samples that portray a moment in time on sparse intervals cannot be used to conclude that water quality standards, as written in State Administrative Rules, are being met or will be met in the future. DMAs and ODEQ need more information to evaluate effectiveness of TMDL implementation strategies. The sooner water quality monitoring strategies are improved, the sooner the DMAs and ODEQ can focus on other pressing water quality problems in the watershed and/or around the state, assess effectiveness, and adapt needed management strategies. In addition, increased monitoring data will help keep the public informed about conditions in their watershed and the importance of protecting water quality.

\section{References}

Chesapeake Bay. 2015. 2017, 2025 WIP and Water Quality Standards Attainment \& Monitoring Outcomes, Management Strategy. Chesapeake Bay Program, Annapolis Maryland.

City of Eugene. 2008. City of Eugene, Oregon TMDL Implementation Plan. City of Eugene, Oregon Environmental Services, Eugene Oregon.

Ecology and Society. n/d. http://www.ecologyandsociety.org/vol14/iss2/art36/figure1.html

EPA. 2012. 5.11 Fecal Bacteria. Retrieved May 23, 2016, from

https://archive.epa.gov/water/archive/web/html/vms511.html

EPA. 2012. 5.2 Dissolved Oxygen. Retrieved May 23, 2016, from https://archive.epa.gov/water/archive/web/html/vms511.html

Hyndman, R. J., \& Athanasopoulos, G. 2016. Forecasting: Principles and practice. 
King, K.W., Harmel R.D. 2003. Considerations in Selecting a Water Quality Sampling Strategy. American Society of Agricultural Engineers. Vol. 46(1): pgs. 63-73

Lane County. 2008. Lane County Willamette Basin TMDL Implementation Plan. Lane County Public Works Department, Lane County Oregon.

LTWC. n/d. http://www.longtom.org/wp-content/uploads/2012/05/fig1-subbasinslanduse.jpg

LTWC. 2000. Long Tom Watershed Assessment. Long Tom Watershed Council, Eugene Oregon.

LTWC. 2003. Long Tom Watershed Council Water Quality Monitoring Final Report. Long Tom Watershed Council, Eugene Oregon.

Maslia, M. L., Sautner, J. B., Valenzuela, C., Grayman, W. M., Aral, M. M., \& Green, J. J. 2005. Use of Continuous Recording Water-Quality Monitoring Equipment for Conducting WaterDistribution System Tracer Tests: The Good, the Bad and the Ugly. Impacts of Global Climate Change. doi:10.1061/40792(173)283

Meals, D.W., Dressing, S.A., and Davenport, T.E. 2009. Lag Time in Water Quality Response to Best Management Practices: A Review. American Society of Agronomy. Vol 39(1): pgs. 85-96. doi: 10.2134/jeq2009.0108

ODEQ. 2006. Willamette Basin TMDL. Chapter 10. Oregon Department of Environmental Quality, Salem Oregon.

ODEQ. 2014. Five Year DMA Report - Willamette Basin TMDL Implementation. Oregon Department of Environmental Quality, Salem Oregon.

ODA. 2007. Upper Willamette and Upper Siuslaw Agricultural Water Quality Management Area Plan. Oregon Department of Agriculture, Salem Oregon.

Oram, B. 2014. Total coliform bacteria are a collection of relatively harmless microorganisms that live in large numbers in the intestines of man and warm- and cold-blooded animals. Retrieved May 23, 2016, from http://www.water-research.net/index.php/e-coli-in-water

EPA. 1991. Guidance for Water-Quality-based Decisions: The TMDL Process, EPA440-4-91$001 \mathrm{hltp}: / /$ www.epa.gov/OWOW/tmdl/decisions/

USA Water Quality. 2010. Why Volunteer Water Quality Monitoring Makes Sense, Factsheet II. USDA National Facilitation of CSREES Volunteer Monitoring Efforts. United States Department of Agriculture. Washington District of Columbia.

USP 594. 2011. Environmental Migrants and the Future of the Willamette Valley, A Preliminary Exploration. United States Planning

WHO. 1996. Water Quality Assessments - A guide to Use of Biota Sediments and Water in Environmental Monitoring - Second Edition. United Nations Educational, Scientific and Cultural Organization. World Health Organization United Nations Environmental Program. Cambridge Great Britain. 


\section{Appendix A \\ Data Summaries: \\ Central Tendency, Range, and Exceedance Percentage and Change of Before and After 2008}




\section{Bacteria (E. coli)}

\section{Upper Amazon}

\section{Amazon Creek at 29 $^{\text {th }}$ Avenue}

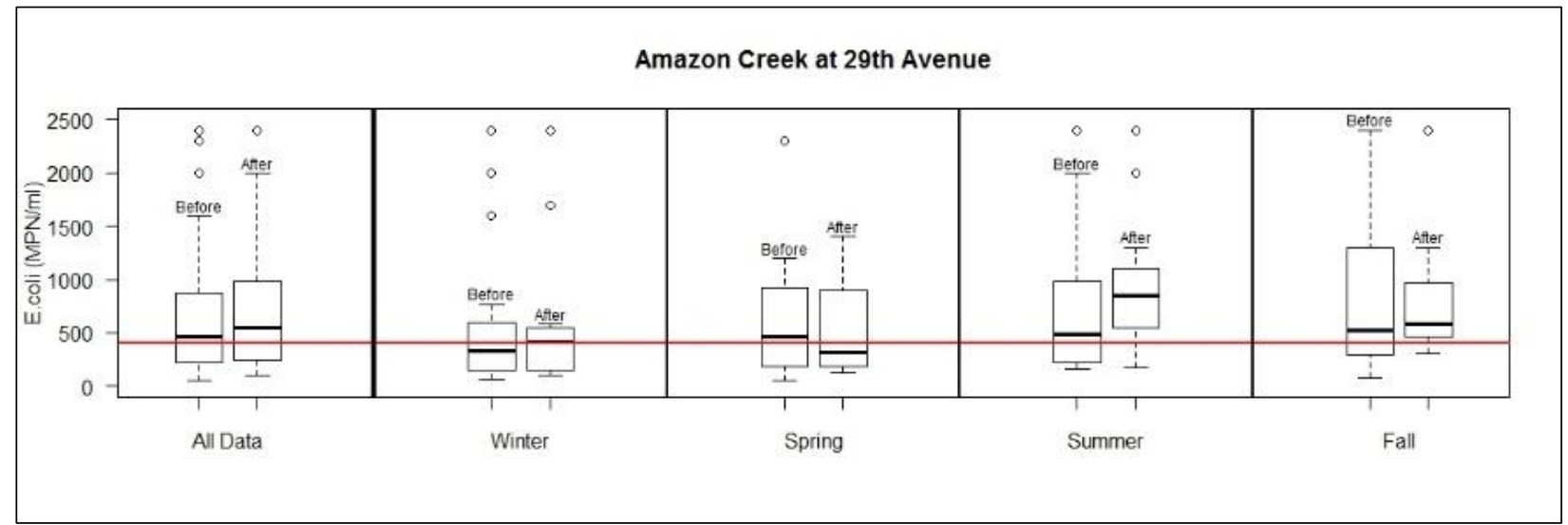

Figure 1: Box and whiskers plots of $E$. coli data on Amazon Creek at $29^{\text {th }}$ Avenue. The horizontal red line is State single sample exceedance level (406 E. coli organisms (MPN)/100 ml).

Table 1: Data summaries of E. coli on Amazon Creek at $29^{\text {th }}$ Avenue.

\begin{tabular}{|c|c|c|c|c|c|c|c|c|c|}
\hline & & $\mathbf{N}$ & Min & Q1 & Geometric Mean & Q3 & Max & $\%$ Exceeded & $\Delta \%$ Exceeded \\
\hline \multirow{2}{*}{ All Data } & Before & 65 & 54 & 220 & 738 & 870 & 2400 & $58 \%$ & \multirow{2}{*}{$+6 \%$} \\
\hline & After & 45 & 100 & 250 & 764 & 980 & 2400 & $64 \%$ & \\
\hline \multirow{2}{*}{ Winter } & Before & 18 & 59 & 168 & 600 & 588 & 2400 & $44 \%$ & \multirow{2}{*}{$+9 \%$} \\
\hline & After & 15 & 100 & 145 & 672 & 550 & 2400 & $53 \%$ & \\
\hline \multirow{2}{*}{ Spring } & Before & 14 & 54 & 205 & 624 & 898 & 2300 & $64 \%$ & \multirow{2}{*}{$-20 \%$} \\
\hline & After & 9 & 130 & 200 & 592 & 980 & 1400 & $44 \%$ & \\
\hline \multirow{2}{*}{ Summer } & Before & 19 & 160 & 225 & 825 & 980 & 2400 & $63 \%$ & \multirow{2}{*}{$+15 \%$} \\
\hline & After & 14 & 170 & 550 & 914 & 1075 & 2400 & $79 \%$ & \\
\hline \multirow{2}{*}{ Fall } & Before & 14 & 79 & 313 & 900 & 1275 & 2400 & $65 \%$ & \multirow{2}{*}{$+21 \%$} \\
\hline & After & 7 & 310 & 465 & 881 & 975 & 2400 & $86 \%$ & \\
\hline
\end{tabular}

* Bold and shaded indicate State single sample criterion exceedance

\section{Amazon Creek at Railroad Crossing}

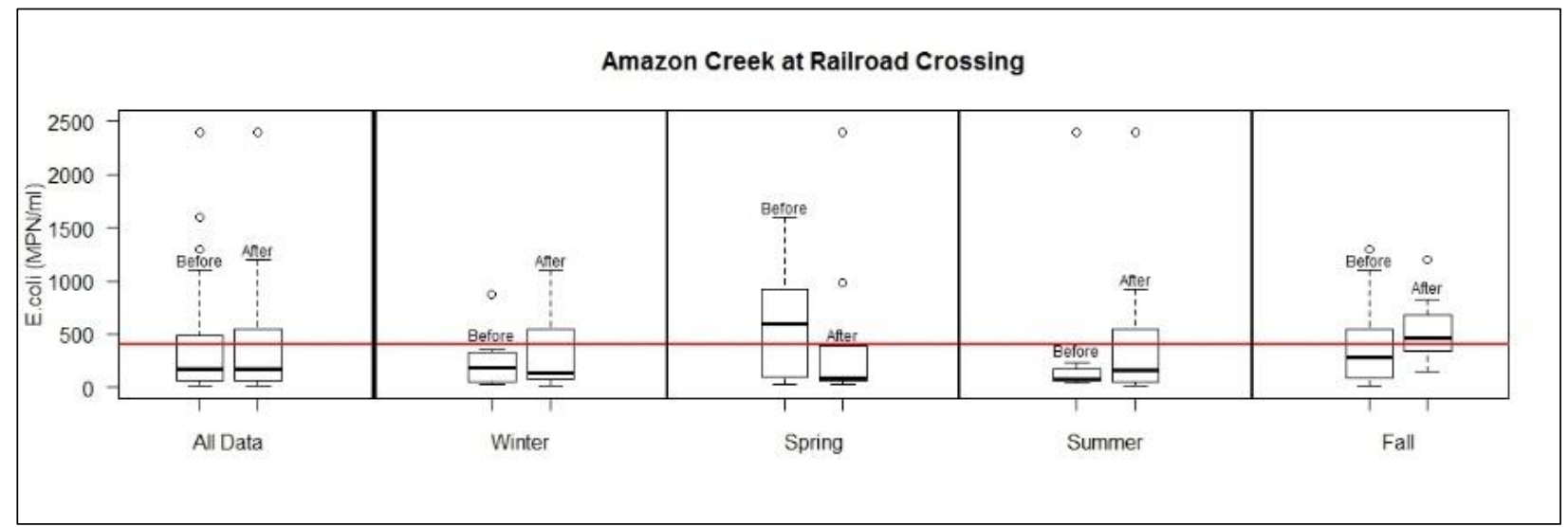


Figure 2: Box and whiskers plots of $E$. coli data on Amazon Creek at Railroad Crossing. The horizontal red line is State single sample exceedance level (406 E. coli organisms (MPN)/100 ml).

Table 2: Data summaries of E. coli on Amazon Creek at Railroad Crossing.

\begin{tabular}{|c|c|c|c|c|c|c|c|c|c|}
\hline & & $\mathbf{N}$ & Min & Q1 & Geometric Mean & Q3 & Max & $\%$ Exceeded & $\Delta \%$ Exceeded \\
\hline \multirow{2}{*}{ All Data } & Before & 46 & 14 & 65 & 378 & 460 & 2400 & $26 \%$ & \multirow{2}{*}{$+10 \%$} \\
\hline & After & 45 & 10 & 70 & 420 & 550 & 2400 & $36 \%$ & \\
\hline \multirow{2}{*}{ Winter } & Before & 12 & 33 & 59 & 276 & 315 & 870 & $17 \%$ & \multirow{2}{*}{$+16 \%$} \\
\hline & After & 15 & 15 & 78 & 335 & 545 & 1100 & $33 \%$ & \\
\hline \multirow{2}{*}{ Spring } & Before & 10 & 23 & 130 & 595 & 895 & 1600 & $60 \%$ & \multirow{2}{*}{$-38 \%$} \\
\hline & After & 9 & 33 & 66 & 466 & 390 & 2400 & $22 \%$ & \\
\hline \multirow{2}{*}{ Summer } & Before & 13 & 46 & 63 & 285 & 170 & 2400 & $8 \%$ & \multirow{2}{*}{$+28 \%$} \\
\hline & After & 14 & 10 & 47 & 414 & 490 & 2400 & $36 \%$ & \\
\hline \multirow{2}{*}{ Fall } & Before & 11 & 14 & 86 & 404 & 550 & 1300 & $27 \%$ & \multirow{2}{*}{$+30 \%$} \\
\hline & After & 7 & 150 & 345 & 553 & 685 & 1200 & $57 \%$ & \\
\hline
\end{tabular}

* Bold and shaded indicate State single sample criterion exceedance

\section{Amazon Creek at Royal Avenue}

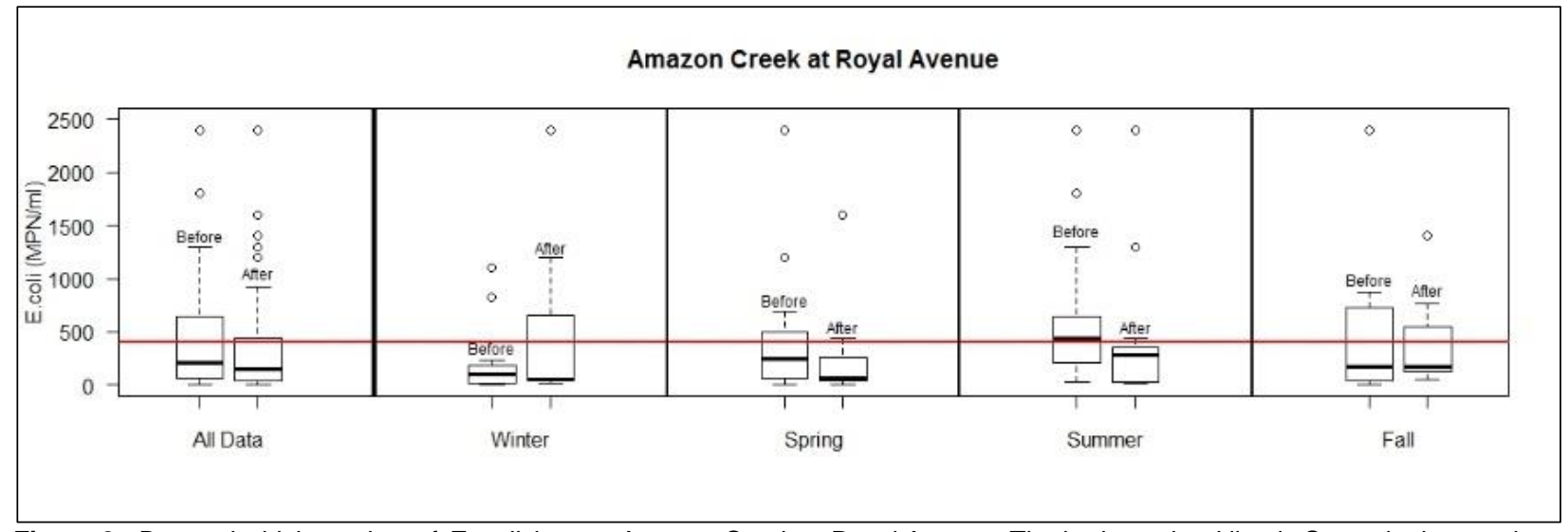

Figure 3: Box and whiskers plots of E. coli data on Amazon Creek at Royal Avenue. The horizontal red line is State single sample exceedance level (406 E. coli organisms (MPN)/100 ml).

Table 3: Data summaries of E. coli on Amazon Creek at Royal Avenue.

\begin{tabular}{|c|c|c|c|c|c|c|c|c|c|}
\hline & & $\mathbf{N}$ & Min & Q1 & Geometric Mean & Q3 & $\operatorname{Max}$ & \% Exceeded & $\Delta \%$ Exceeded \\
\hline \multirow{2}{*}{ All Data } & Before & 65 & 2 & 57 & 454 & 650 & 2400 & $37 \%$ & \multirow{2}{*}{$-7 \%$} \\
\hline & After & 44 & 5 & 41 & 412 & 460 & 2400 & $30 \%$ & \\
\hline \multirow{2}{*}{ Winter } & Before & 18 & 9 & 22 & 186 & 178 & 1100 & $11 \%$ & \multirow{2}{*}{$+29 \%$} \\
\hline & After & 15 & 10 & 44 & 455 & 655 & 2400 & $40 \%$ & \\
\hline \multirow{2}{*}{ Spring } & Before & 14 & 2 & 65 & 457 & 483 & 2400 & $36 \%$ & \multirow{2}{*}{$-14 \%$} \\
\hline & After & 9 & 5 & 40 & 288 & 260 & 1600 & $22 \%$ & \\
\hline \multirow{2}{*}{ Summer } & Before & 19 & 29 & 215 & 603 & 650 & 2400 & $58 \%$ & \multirow{2}{*}{$-35 \%$} \\
\hline & After & 13 & 10 & 26 & 440 & 360 & 2400 & $23 \%$ & \\
\hline \multirow{2}{*}{ Fall } & Before & 14 & 5 & 36 & 596 & 750 & 2400 & $43 \%$ & \multirow{2}{*}{$-14 \%$} \\
\hline & After & 7 & 53 & 123 & 424 & 550 & 1400 & $29 \%$ & \\
\hline
\end{tabular}

* Bold and shaded indicate State single sample criterion exceedance

\section{Willow Creek at $18^{\text {th }}$ Avenue}


Willow Creek at 18th Avenue

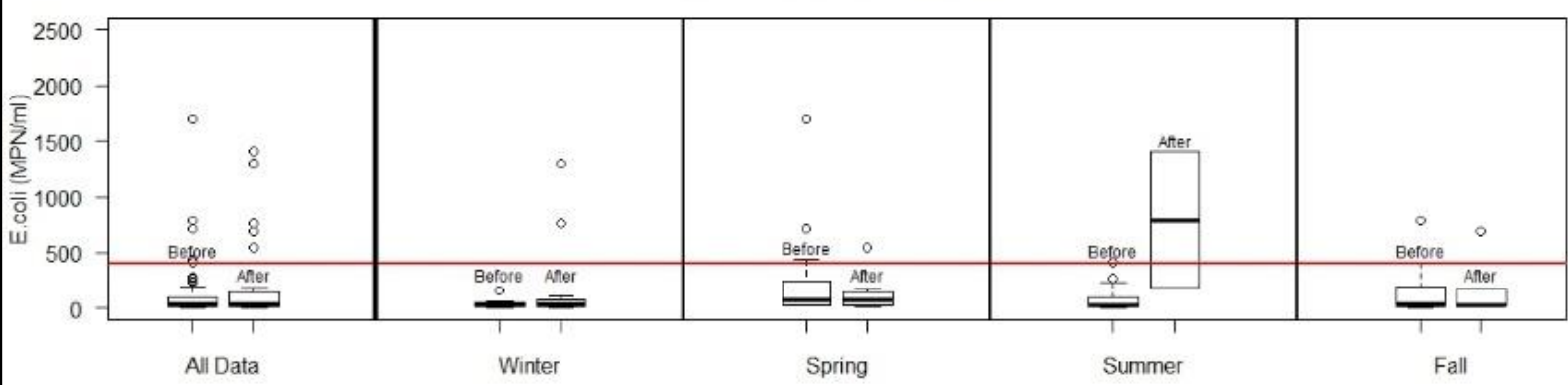

Figure 4: Box and whiskers plots of E. coli data on Willow Creek at 18th Avenue. The horizontal red line is State single sample exceedance level (406 E. coli organisms (MPN)/100 ml).

Table 4: Data summaries of E. coli on Willow Creek at 18th Avenue.

\begin{tabular}{|c|c|c|c|c|c|c|c|c|c|}
\hline & & $\mathbf{N}$ & Min & Q1 & Geometric Mean & Q3 & Max & $\%$ Exceeded & $\Delta \%$ Exceeded \\
\hline \multirow{2}{*}{ All Data } & Before & 64 & 1 & 18 & 123 & 100 & 1700 & $9 \%$ & \multirow{2}{*}{$+7 \%$} \\
\hline & After & 31 & 9 & 20 & 199 & 150 & 1400 & $16 \%$ & \\
\hline \multirow{2}{*}{ Winter } & Before & 18 & 7 & 19 & 40 & 50 & 160 & $0 \%$ & \multirow{2}{*}{$+13 \%$} \\
\hline & After & 15 & 9 & 13 & 170 & 73 & 1300 & $13 \%$ & \\
\hline \multirow{2}{*}{ Spring } & Before & 14 & 29 & 37 & 270 & 233 & 1700 & $21 \%$ & \multirow{2}{*}{$-8 \%$} \\
\hline & After & 8 & 15 & 27 & 133 & 140 & 550 & $13 \%$ & \\
\hline \multirow{2}{*}{ Summer } & Before & 18 & 1 & 12 & 81 & 98 & 410 & $6 \%$ & \multirow{2}{*}{$+44 \%$} \\
\hline & After & 2 & 180 & 485 & 790 & 1095 & 1400 & $50 \%$ & \\
\hline \multirow{2}{*}{ Fall } & Before & 14 & 2 & 13 & 147 & 190 & 790 & $14 \%$ & \multirow{2}{*}{$+3 \%$} \\
\hline & After & 6 & 21 & 24 & 161 & 136 & 690 & $17 \%$ & \\
\hline
\end{tabular}

* Bold and shaded indicate State single sample criterion exceedance

\section{Amazon Diversion Channel at Royal Avenue}

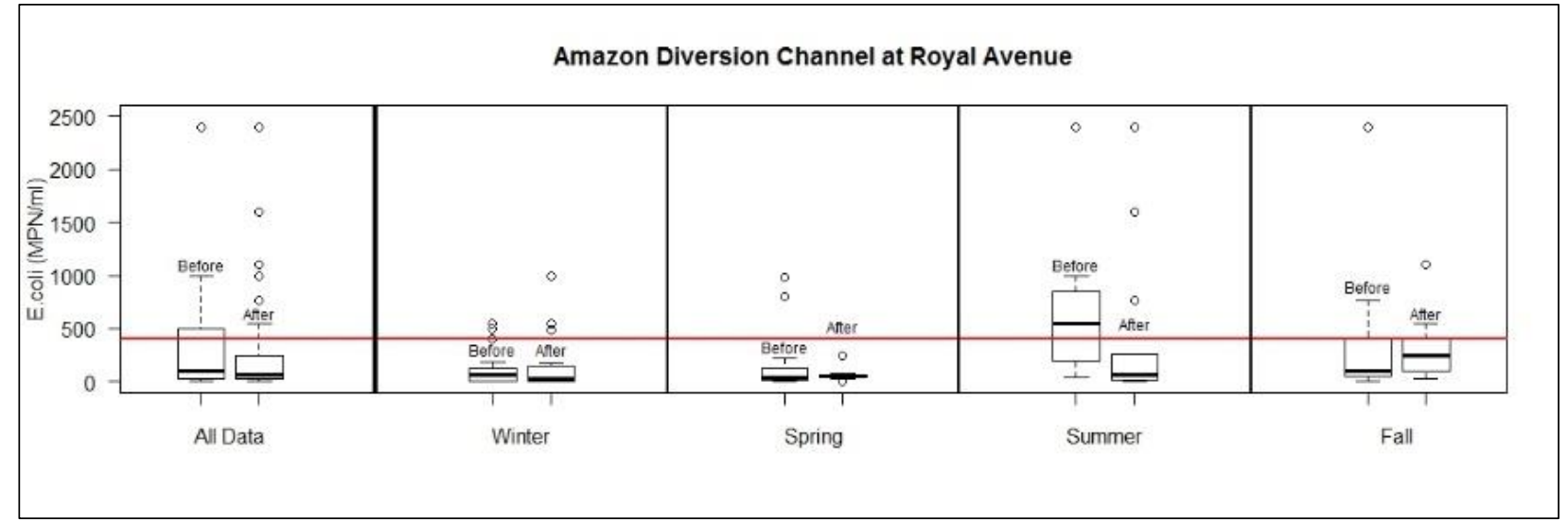

Figure 5: Box and whiskers plots of E. coli data on Amazon Diversion Channel at Royal Avenue. The horizontal red line is State single sample exceedance level (406 E. coli organisms (MPN)/100 ml).

Table 5: Data summaries of E. coli on Amazon Diversion Channel at Royal Avenue.

\begin{tabular}{|c|c|c|c|c|c|c|c|c|c|}
\hline & & $\mathbf{N}$ & Min & Q1 & Geometric Mean & Q3 & $\operatorname{Max}$ & $\%$ Exceeded & $\Delta \%$ Exceeded \\
\hline \multirow{2}{*}{ All Data } & Before & 64 & 1 & 33 & 344 & 500 & 2400 & $28 \%$ & \multirow{2}{*}{$-10 \%$} \\
\hline & After & 45 & 1 & 24 & 252 & 240 & 2400 & $18 \%$ & \\
\hline \multirow{2}{*}{ Winter } & Before & 18 & 1 & 2 & 119 & 117 & 550 & $11 \%$ & \multirow{2}{*}{$+9 \%$} \\
\hline & After & 15 & 1 & 6 & 177 & 150 & 1000 & $20 \%$ & \\
\hline Spring & Before & 13 & 5 & 19 & 188 & 130 & 980 & $15 \%$ & $-15 \%$ \\
\hline
\end{tabular}




\begin{tabular}{|c|r|c|c|c|c|c|c|c|c|}
\hline & After & 9 & 7 & 44 & 70 & 63 & 240 & $0 \%$ & \\
\hline \multirow{3}{*}{ Summer } & Before & 19 & 38 & 195 & $\mathbf{6 7 4}$ & $\mathbf{8 4 5}$ & $\mathbf{2 4 0 0}$ & $58 \%$ & \multirow{2}{*}{$-31 \%$} \\
\cline { 2 - 11 } & After & 11 & 5 & 20 & 404 & 245 & $\mathbf{2 4 0 0}$ & $27 \%$ & \\
\hline \multirow{3}{*}{ Fall } & Before & 10 & 1 & 53 & 356 & 355 & $\mathbf{2 4 0 0}$ & $30 \%$ & $+1 \%$ \\
\cline { 2 - 10 } & After & 7 & 28 & 100 & 341 & 405 & $\mathbf{1 1 0 0}$ & $29 \%$ & \\
\hline
\end{tabular}

* Bold and shaded indicate State single sample criterion exceedance

\section{A-3 Drain at Terry Street}

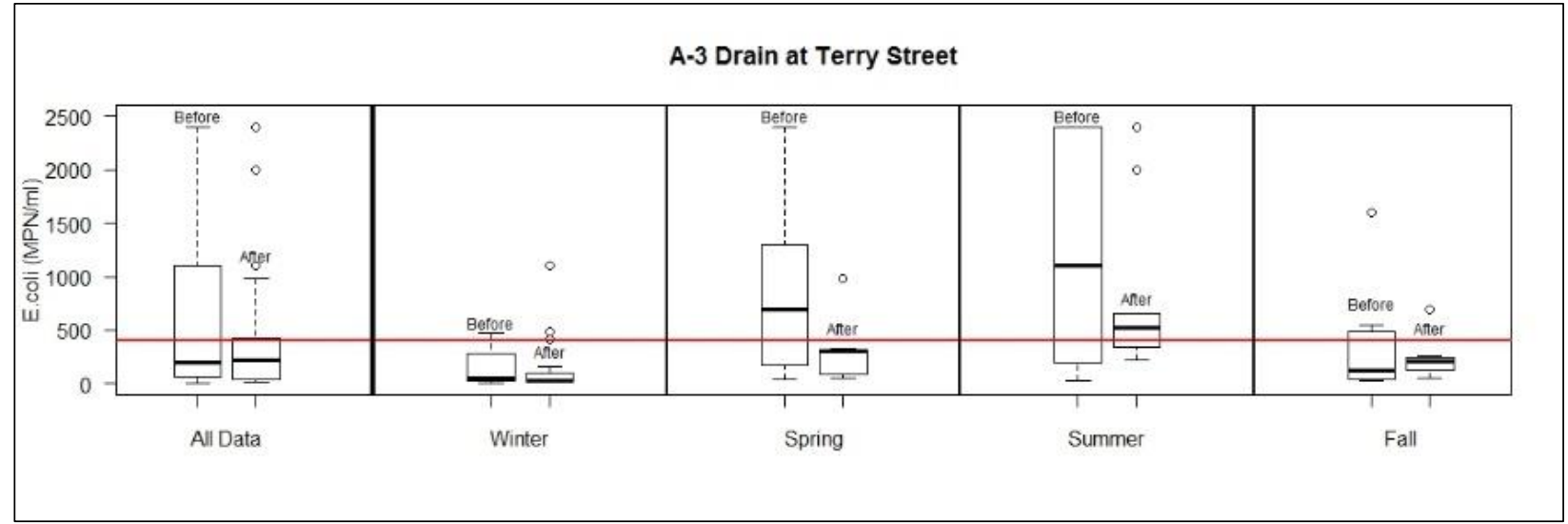

Figure 6: Box and whiskers plots of E. coli data on A-3 Drain at Terry Street. The horizontal red line is State single sample exceedance level (406 E. coli organisms (MPN)/100 ml).

Table 6: Data summaries of E. coli on A-3 Drain at Terry Street.

\begin{tabular}{|c|c|c|c|c|c|c|c|c|c|}
\hline & & $\mathbf{N}$ & Min & Q1 & Geometric Mean & Q3 & $\operatorname{Max}$ & $\%$ Exceeded & $\Delta \%$ Exceeded \\
\hline \multirow{2}{*}{ All Data } & Before & 43 & 5 & 65 & 687 & 1100 & 2400 & $39 \%$ & \multirow{2}{*}{$-11 \%$} \\
\hline & After & 40 & 10 & 37 & 358 & 418 & 2400 & $28 \%$ & \\
\hline \multirow{2}{*}{ Winter } & Before & 12 & 5 & 24 & 140 & 240 & 480 & $8 \%$ & \multirow{2}{*}{$+12 \%$} \\
\hline & After & 15 & 10 & 17 & 160 & 99 & 1100 & $20 \%$ & \\
\hline \multirow{2}{*}{ Spring } & Before & 9 & 42 & 170 & 939 & 1300 & 2400 & $56 \%$ & \multirow{2}{*}{$-45 \%$} \\
\hline & After & 9 & 53 & 88 & 299 & 320 & 980 & $11 \%$ & \\
\hline \multirow{2}{*}{ Summer } & Before & 12 & 23 & 200 & 1264 & 2400 & 2400 & $62 \%$ & \multirow{2}{*}{$+5 \%$} \\
\hline & After & 9 & 220 & 340 & 836 & 660 & 2400 & $67 \%$ & \\
\hline \multirow{2}{*}{ Fall } & Before & 10 & 24 & 56 & 325 & 405 & 1600 & $30 \%$ & \multirow{2}{*}{$-16 \%$} \\
\hline & After & 7 & 52 & 130 & 242 & 240 & 690 & $14 \%$ & \\
\hline
\end{tabular}

* Bold and shaded indicate State single sample criterion exceedance

\section{Lower Amazon}

\section{Amazon Creek at RM 5.82}

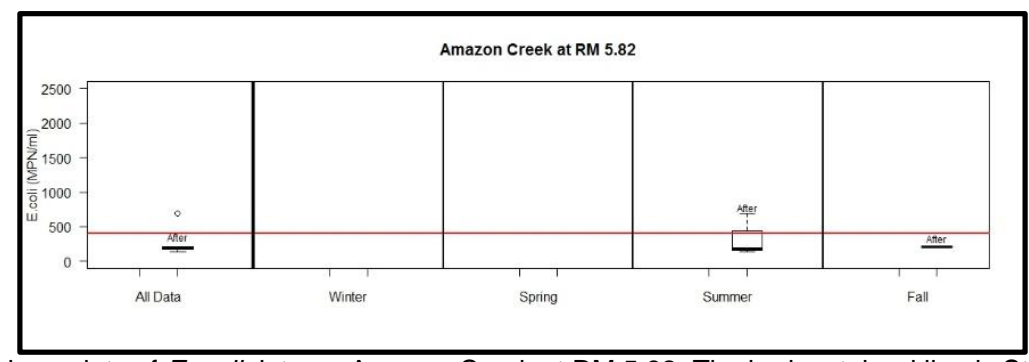

Figure 7: Box and whiskers plots of E. coli data on Amazon Creek at RM 5.82. The horizontal red line is State single sample exceedance level (406 E. coli organisms (MPN)/100 ml).

Table 7: Data summaries of E. coli on Amazon Creek at RM 5.82. 


\begin{tabular}{|c|c|c|c|c|c|c|c|c|c|c|}
\hline & & $\mathbf{N}$ & Min & Q1 & Median & Geometric Mean & Q3 & Max & $\%$ Exceeded & $\Delta \%$ Exceeded \\
\hline \multirow{2}{*}{ All Data } & Before & 0 & \multicolumn{7}{|c|}{$\mathrm{N} / \mathrm{A}$} & \multirow{2}{*}{$\mathrm{N} / \mathrm{A}$} \\
\hline & After & 5 & 135 & 178 & 186 & 280 & 214 & 687 & $20 \%$ & \\
\hline \multirow{2}{*}{ Winter } & Before & 0 & \multicolumn{7}{|c|}{$\mathrm{N} / \mathrm{A}$} & \multirow{2}{*}{$\mathrm{N} / \mathrm{A}$} \\
\hline & After & 0 & \multicolumn{7}{|c|}{$\mathrm{N} / \mathrm{A}$} & \\
\hline \multirow{2}{*}{ Spring } & Before & 0 & & & & $\mathrm{~N} / \mathrm{A}$ & & & & \multirow{2}{*}{$\mathrm{N} / \mathrm{A}$} \\
\hline & After & 0 & & & & $\mathrm{~N} / \mathrm{A}$ & & & & \\
\hline \multirow{2}{*}{ Summer } & Before & 0 & & & & $\mathrm{~N} / \mathrm{A}$ & & & & \multirow{2}{*}{$\mathrm{N} / \mathrm{A}$} \\
\hline & After & 5 & 135 & 178 & 186 & 280 & 214 & 687 & $20 \%$ & \\
\hline \multirow{2}{*}{ Fall } & Before & 0 & \multirow{2}{*}{\multicolumn{7}{|c|}{$\mathrm{N} / \mathrm{A}$}} & \multirow{2}{*}{$\mathrm{N} / \mathrm{A}$} \\
\hline & After & 0 & & & & \multicolumn{3}{|l|}{$\mathrm{N} / \mathrm{A}$} & & \\
\hline
\end{tabular}

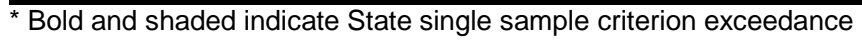

\section{Amazon Creek at High Pass Road}

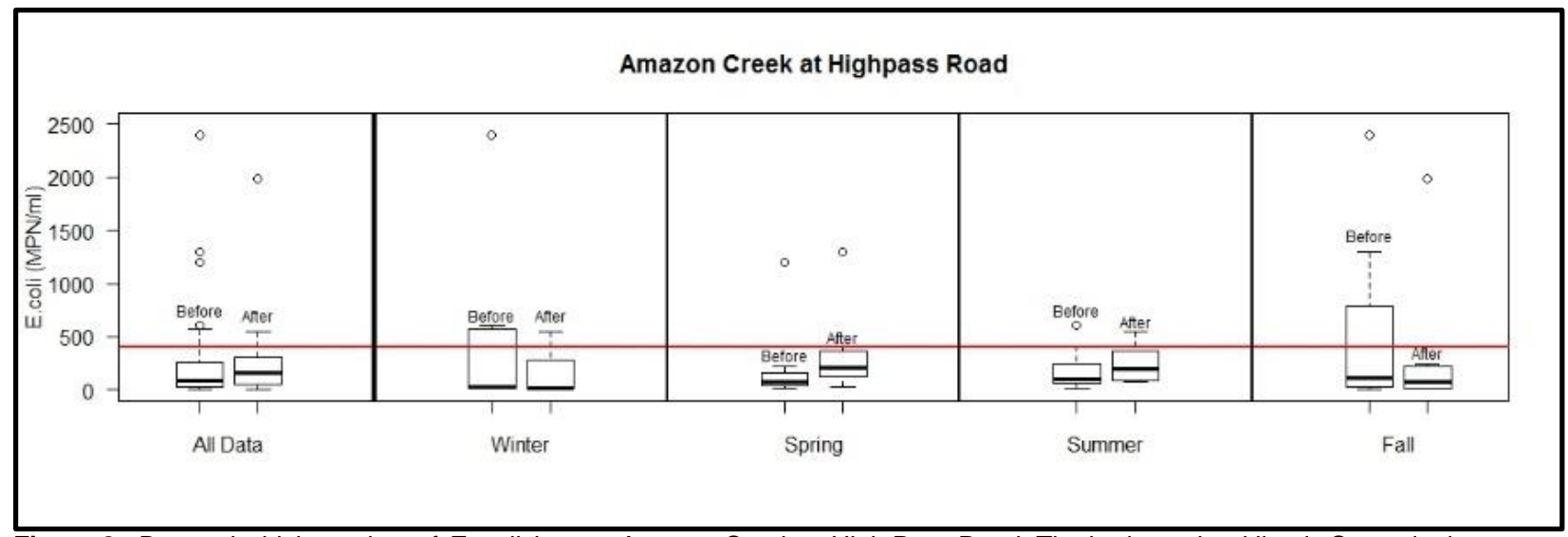

Figure 8: Box and whiskers plots of E. coli data on Amazon Creek at High Pass Road. The horizontal red line is State single sample exceedance level (406 E. coli organisms (MPN)/100 ml).

Table 8: Data summaries of E. coli on Amazon Creek at High Pass Road.

\begin{tabular}{|c|c|c|c|c|c|c|c|c|c|}
\hline & & $\mathbf{N}$ & Min & Q1 & Geometric Mean & Q3 & $\operatorname{Max}$ & $\%$ Exceeded & $\Delta \%$ Exceeded \\
\hline \multirow{2}{*}{ All Data } & Before & 42 & 5 & 32 & 306 & 252 & 2400 & $24 \%$ & \multirow[b]{2}{*}{$+3 \%$} \\
\hline & After & 22 & 8 & 64 & 276 & 278 & 1986 & $27 \%$ & \\
\hline \multirow{2}{*}{ Winter } & Before & 10 & 10 & 14 & 394 & 493 & 2400 & $30 \%$ & \multirow{2}{*}{$+30 \%$} \\
\hline & After & 5 & 8 & 11 & 190 & 281 & 548 & $60 \%$ & \\
\hline \multirow{2}{*}{ Spring } & Before & 15 & 20 & 42 & 257 & 207 & 1300 & $13 \%$ & \multirow{2}{*}{$+12 \%$} \\
\hline & After & 4 & 72 & 152 & 218 & 260 & 411 & $25 \%$ & \\
\hline \multirow{2}{*}{ Summer } & Before & 14 & 13 & 669 & 167 & 226 & 613 & $14 \%$ & \multirow{2}{*}{$+3 \%$} \\
\hline & After & 6 & 73 & 107 & 244 & 333 & 548 & $17 \%$ & \\
\hline \multirow{2}{*}{ Fall } & Before & 10 & 5 & 31 & 513 & 784 & 2400 & $30 \%$ & \multirow{2}{*}{$-16 \%$} \\
\hline & After & 7 & 14 & 21 & 304 & 225 & 1986 & $14 \%$ & \\
\hline
\end{tabular}

* Bold and shaded indicate State single sample criterion exceedance

\section{Coyote Creek}

\section{Coyote Creek at Hamm Road}




\section{Coyote Creek at Hamm Road}

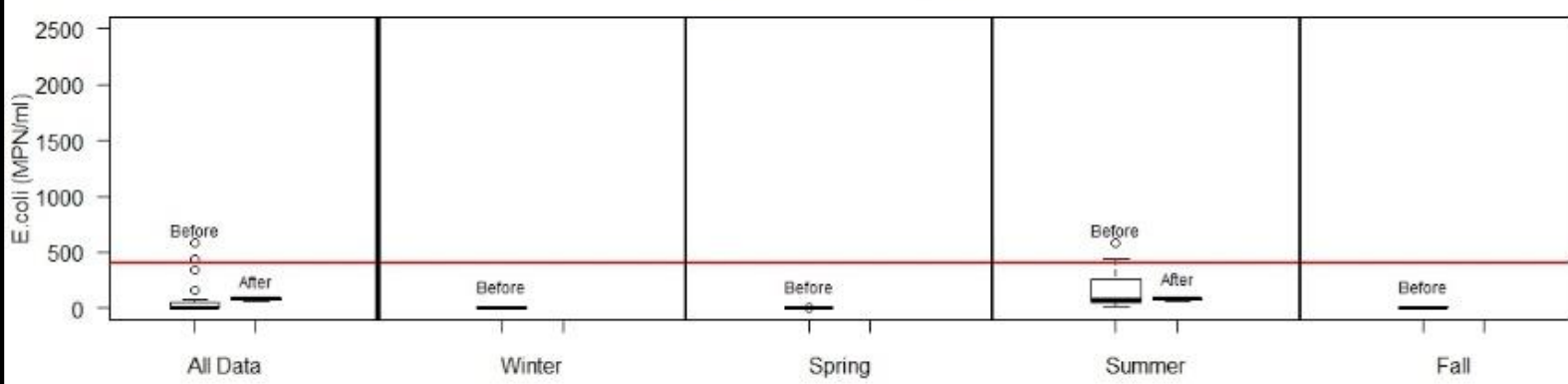

Figure 9: Box and whiskers plots of E. coli data on Coyote Creek at Hamm Road. The horizontal red line is State single sample exceedance level (406 E. coli organisms (MPN)/100 ml).

Table 9: Data summaries of E. coli on Coyote Creek at Hamm Road.

\begin{tabular}{|c|c|c|c|c|c|c|c|c|c|}
\hline & & $\mathbf{N}$ & Min & Q1 & Geometric Mean & Q3 & Max & \% Exceeded & $\Delta \%$ Exceeded \\
\hline \multirow{2}{*}{ All Data } & Before & 28 & 1 & 1 & 67 & 56 & 579 & $7 \%$ & \multirow{2}{*}{$-7 \%$} \\
\hline & After & 4 & 59 & 83 & 84 & 93 & 93 & $0 \%$ & \\
\hline \multirow{2}{*}{ Winter } & Before & 3 & 1 & 1 & 2 & 2 & 3 & $0 \%$ & \multirow{2}{*}{$\mathrm{N} / \mathrm{A}$} \\
\hline & After & 0 & \multicolumn{6}{|c|}{$\mathrm{N} / \mathrm{A}$} & \\
\hline \multirow{2}{*}{ Spring } & Before & 10 & 1 & 1 & 2 & 2 & 8 & $0 \%$ & \multirow{2}{*}{$\mathrm{N} / \mathrm{A}$} \\
\hline & After & 0 & \multicolumn{6}{|c|}{$\mathrm{N} / \mathrm{A}$} & \\
\hline \multirow{2}{*}{ Summer } & Before & 11 & 15 & 54 & 172 & 256 & 579 & $18 \%$ & \multirow{2}{*}{$-18 \%$} \\
\hline & After & 4 & 59 & 83 & 84 & 93 & 93 & $0 \%$ & \\
\hline \multirow{2}{*}{ Fall } & Before & 4 & 1 & 2 & 7 & 10 & 14 & $0 \%$ & \multirow{2}{*}{$\mathrm{N} / \mathrm{A}$} \\
\hline & After & 0 & \multicolumn{6}{|c|}{$N / A$} & \\
\hline
\end{tabular}

** Bold and shaded indicates significance was found

Coyote Creek at Powell Road

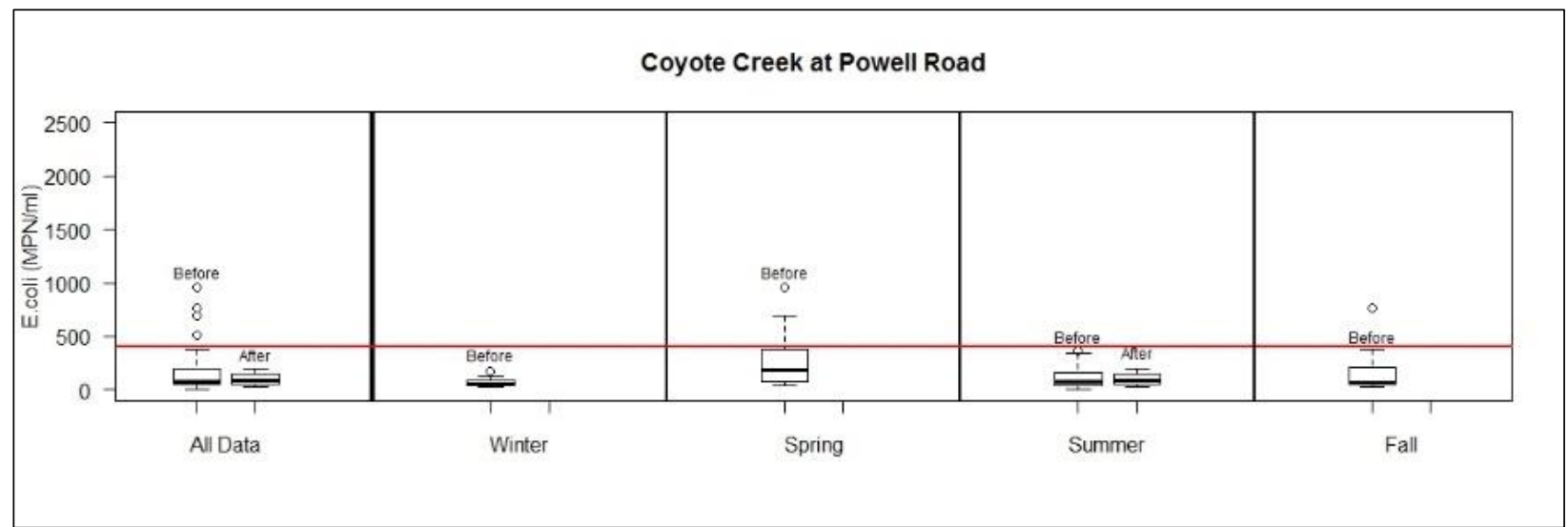

Figure 10: Box and whiskers plots of E. coli data on Coyote Creek at Powell Road. The horizontal red line is State single sample exceedance level (406 E. coli organisms (MPN)/100 ml).

Table 10: Data summaries of E. coli on Coyote Creek at Powell Road.

\begin{tabular}{|c|c|c|c|c|c|c|c|c|c|}
\hline & & $\mathbf{N}$ & Min & Q1 & Geometric Mean & Q3 & Max & $\%$ Exceeded & $\Delta \%$ Exceeded \\
\hline \multirow{2}{*}{ All Data } & Before & 59 & 9 & 52 & 174 & 197 & 961 & $10 \%$ & \multirow{2}{*}{$-10 \%$} \\
\hline & After & 4 & 25 & 72 & 103 & 122 & 201 & $0 \%$ & \\
\hline \multirow{2}{*}{ Winter } & Before & 10 & 33 & 43 & 75 & 87 & 178 & $0 \%$ & $\mathrm{~N} / \mathrm{A}$ \\
\hline & After & 0 & \multicolumn{6}{|c|}{$\mathrm{N} / \mathrm{A}$} & \\
\hline \multirow{2}{*}{ Spring } & Before & 17 & 41 & 81 & 280 & 309 & 961 & $24 \%$ & $\mathrm{~N} / \mathrm{A}$ \\
\hline & After & 0 & \multicolumn{6}{|c|}{$\mathrm{N} / \mathrm{A}$} & \\
\hline
\end{tabular}




\begin{tabular}{|c|c|c|c|c|c|c|c|c|c|}
\hline & & & & & & & & & \\
\hline \multirow{2}{*}{ Summer } & Before & 19 & 9 & 44 & 117 & 164 & 365 & $0 \%$ & \multirow{2}{*}{$0 \%$} \\
\hline & After & 4 & 25 & 72 & 103 & 122 & 201 & $0 \%$ & \\
\hline \multirow{2}{*}{ Fall } & Before & 11 & 27 & 47 & 204 & 210 & 770 & $18 \%$ & $\mathrm{~N} / \mathrm{A}$ \\
\hline & After & 0 & \multicolumn{6}{|c|}{$\mathrm{N} / \mathrm{A}$} & \\
\hline
\end{tabular}

** Bold and shaded indicates significance was found

\section{Coyote Creek at Petzold Road}

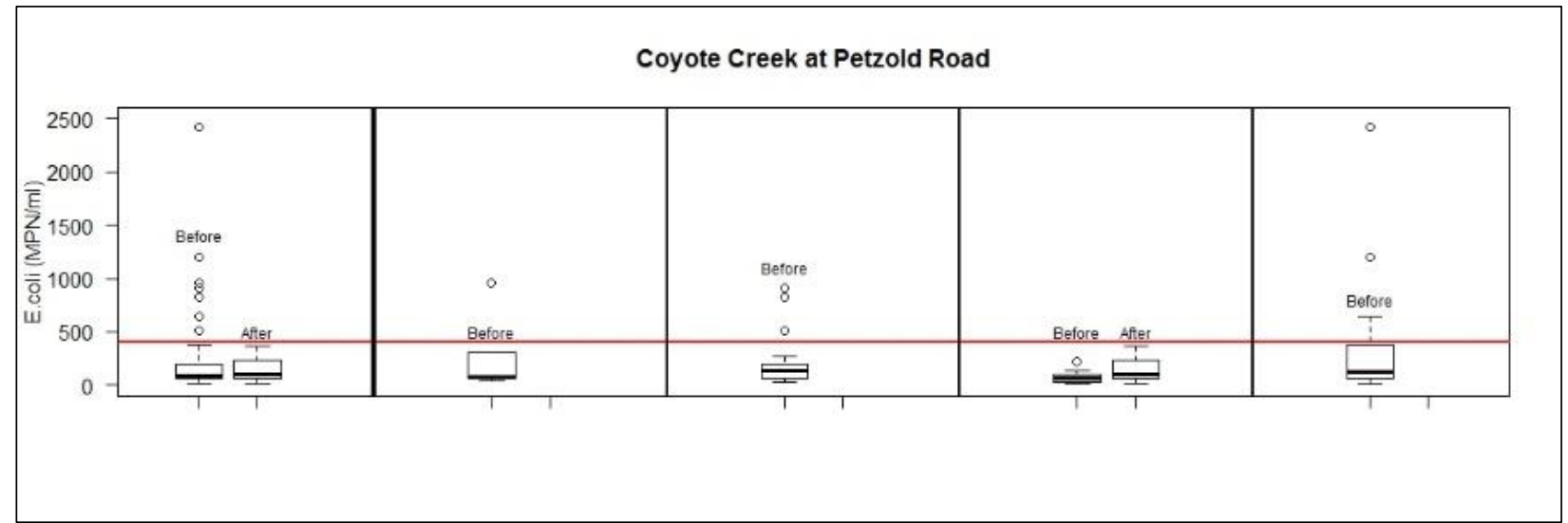

Figure 11: Box and whiskers plots of E. coli data on Coyote Creek at Petzold Road. The horizontal red line is State single sample exceedance level (406 E. coli organisms (MPN)/100 ml).

Table 11: Data summaries of E. coli on Coyote Creek at Petzold Road.

\begin{tabular}{|c|c|c|c|c|c|c|c|c|c|}
\hline & & $\mathbf{N}$ & Min & Q1 & Geometric Mean & Q3 & $\operatorname{Max}$ & $\%$ Exceeded & $\Delta \%$ Exceeded \\
\hline \multirow{2}{*}{ All Data } & Before & 55 & 14 & 60 & 236 & 197 & 2400 & $15 \%$ & \multirow{2}{*}{$-15 \%$} \\
\hline & After & 3 & 20 & 61 & 161 & 231 & 361 & $0 \%$ & \\
\hline \multirow{2}{*}{ Winter } & Before & 10 & 46 & 66 & 723 & 254 & 961 & $20 \%$ & \multirow{2}{*}{$\mathrm{N} / \mathrm{A}$} \\
\hline & After & 0 & \multicolumn{6}{|c|}{$\mathrm{N} / \mathrm{A}$} & \\
\hline \multirow{2}{*}{ Spring } & Before & 17 & 25 & 69 & 226 & 197 & 914 & $18 \%$ & \multirow{2}{*}{$\mathrm{N} / \mathrm{A}$} \\
\hline & After & 0 & \multicolumn{6}{|l|}{$\mathrm{N} / \mathrm{A}$} & \\
\hline \multirow{2}{*}{ Summer } & Before & 15 & 14 & 32 & 72 & 94 & 219 & $0 \%$ & \multirow{2}{*}{$0 \%$} \\
\hline & After & 3 & 20 & 61 & 161 & 231 & 361 & $0 \%$ & \\
\hline \multirow{2}{*}{ Fall } & Before & 13 & 19 & 70 & 410 & 353 & 2400 & $23 \%$ & \multirow{2}{*}{$\mathrm{N} / \mathrm{A}$} \\
\hline & After & 0 & \multicolumn{6}{|c|}{ N/A } & \\
\hline
\end{tabular}

** Bold and shaded indicates significance was found 


\section{Dissolved Oxygen}

\section{Upper Amazon}

\section{Amazon Creek at $29^{\text {th }}$ Avenue}

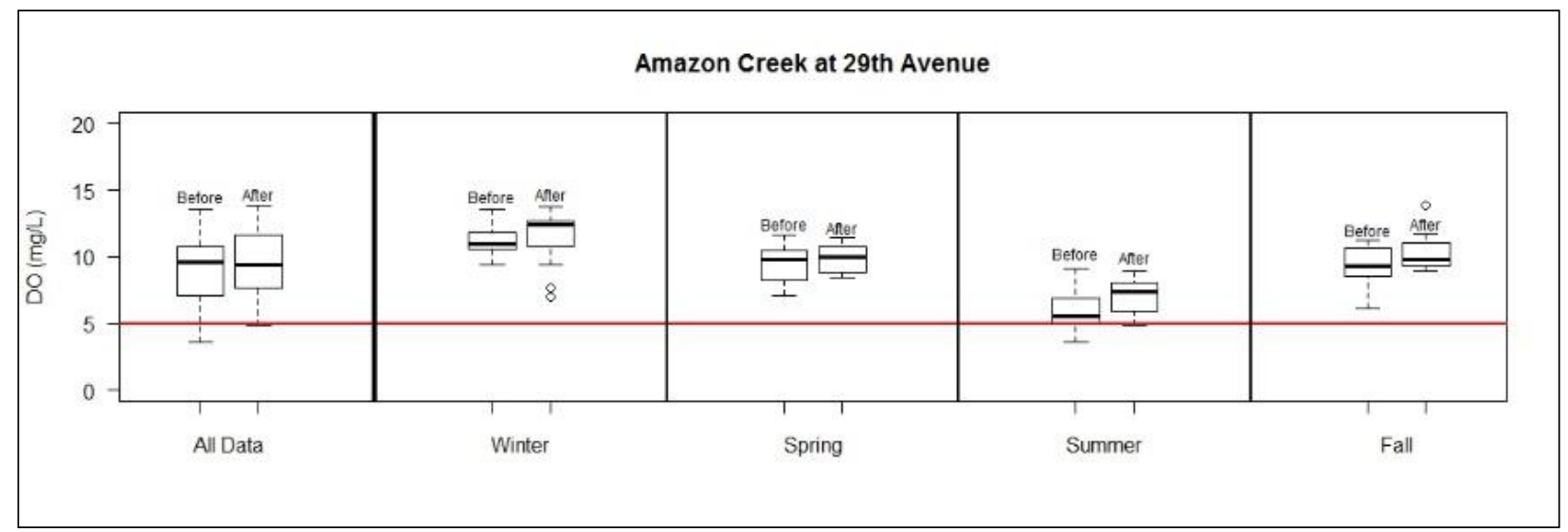

Figure 12: Box and whiskers plots of DO data on Amazon Creek at $29^{\text {th }}$ Avenue. The horizontal red line is State single sample exceedance level of DO $(5.0 \mathrm{mg} / \mathrm{L})$.

Table 12: Data summaries of DO on Amazon Creek at $29^{\text {th }}$ Avenue.

\begin{tabular}{|c|c|c|c|c|c|c|c|c|c|}
\hline & & $\mathbf{N}$ & Min & Q1 & Geometric Mean & Q3 & Max & $\%$ Exceeded & $\Delta \%$ Exceeded \\
\hline \multirow{2}{*}{ All Data } & Before & 65 & 3.6 & 7.1 & 8.9 & 10.8 & 13.6 & $5 \%$ & \multirow{2}{*}{$-3 \%$} \\
\hline & After & 45 & 4.9 & 7.7 & 9.6 & 11.6 & 13.9 & $2 \%$ & \\
\hline \multirow{2}{*}{ Winter } & Before & 18 & 9.4 & 10.7 & 11.1 & 11.8 & 13.6 & $0 \%$ & \multirow{2}{*}{$0 \%$} \\
\hline & After & 15 & 7.0 & 10.8 & 11.5 & 12.6 & 13.8 & $0 \%$ & \\
\hline \multirow{2}{*}{ Spring } & Before & 14 & 7.1 & 8.5 & 9.5 & 10.5 & 11.6 & $0 \%$ & \multirow{2}{*}{$0 \%$} \\
\hline & After & 9 & 7.7 & 8.6 & 9.6 & 10.5 & 11.4 & $0 \%$ & \\
\hline \multirow{2}{*}{ Summer } & Before & 19 & 3.6 & 5.1 & 6.1 & 6.9 & 9.1 & $16 \%$ & \multirow{2}{*}{$-9 \%$} \\
\hline & After & 14 & 4.9 & 6.0 & 7.1 & 8.0 & 8.9 & $7 \%$ & \\
\hline \multirow{2}{*}{ Fall } & Before & 14 & 6.1 & 8.6 & 9.3 & 10. & 11.2 & $0 \%$ & \multirow{2}{*}{$0 \%$} \\
\hline & After & 7 & 8.9 & 9.3 & 105 & 11.1 & 139 & $0 \%$ & \\
\hline
\end{tabular}

* Bold and shaded indicate State single sample criterion exceedance

\section{Amazon Creek at Railroad Crossing}

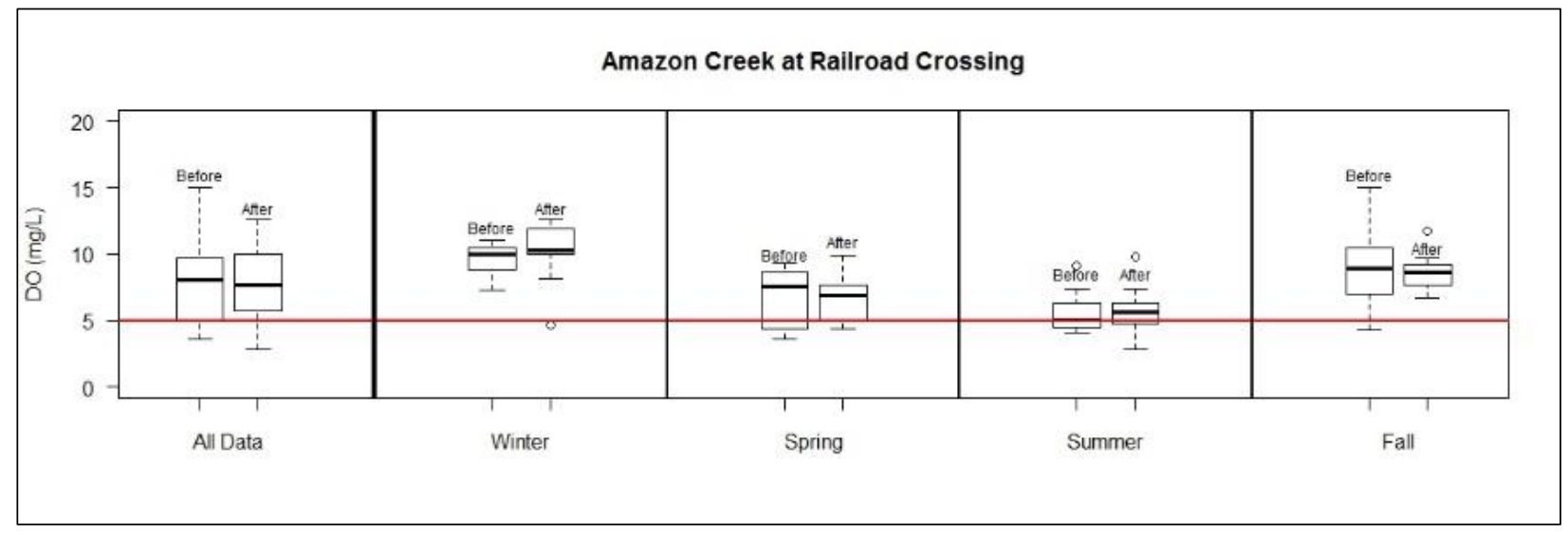


Figure 13: Box and whiskers plots of DO data on Amazon Creek at Railroad Crossing. The horizontal red line is State single sample exceedance level of DO $(5.0 \mathrm{mg} / \mathrm{L})$.

Table 13: Data summaries of DO on Amazon Creek at Railroad Crossing.

\begin{tabular}{|c|c|c|c|c|c|c|c|c|c|}
\hline & & $\mathbf{N}$ & Min & Q1 & Geometric Mean & Q3 & Max & $\%$ Exceeded & $\Delta \%$ Exceeded \\
\hline \multirow{2}{*}{ All Data } & Before & 46 & 3.6 & 5.2 & 7.7 & 9.7 & 15.0 & $22 \%$ & \multirow{2}{*}{$-4 \%$} \\
\hline & After & 45 & 2.8 & 5.7 & 8.0 & 10.0 & 12.6 & $18 \%$ & \\
\hline \multirow{2}{*}{ Winter } & Before & 12 & 7.3 & 8.8 & 9.7 & 10.4 & 11.1 & $0 \%$ & \multirow{2}{*}{$+7 \%$} \\
\hline & After & 15 & 4.4 & 5.0 & 6.8 & 7.7 & 9.9 & $7 \%$ & \\
\hline \multirow{2}{*}{ Spring } & Before & 10 & 4.4 & 5.0 & 6.8 & 7.7 & 9.9 & $40 \%$ & \multirow{2}{*}{$-7 \%$} \\
\hline & After & 9 & 3.6 & 4.5 & 6.7 & 8.6 & 9.3 & $33 \%$ & \\
\hline \multirow{2}{*}{ Summer } & Before & 13 & 4.1 & 4.5 & 5.6 & 6.3 & 9.1 & $38 \%$ & \multirow{2}{*}{$-9 \%$} \\
\hline & After & 14 & 2.8 & 4.9 & 5.7 & 6.2 & 9.8 & $29 \%$ & \\
\hline \multirow{2}{*}{ Fall } & Before & 11 & 4.3 & 7.0 & 9.0 & 10.5 & 15.0 & $9 \%$ & \multirow{2}{*}{$-9 \%$} \\
\hline & After & 7 & 6.7 & 7.7 & 8.7 & 9.3 & 11.7 & $0 \%$ & \\
\hline
\end{tabular}

* Bold and shaded indicate State single sample criterion exceedance

\section{Amazon Creek at Royal Avenue}

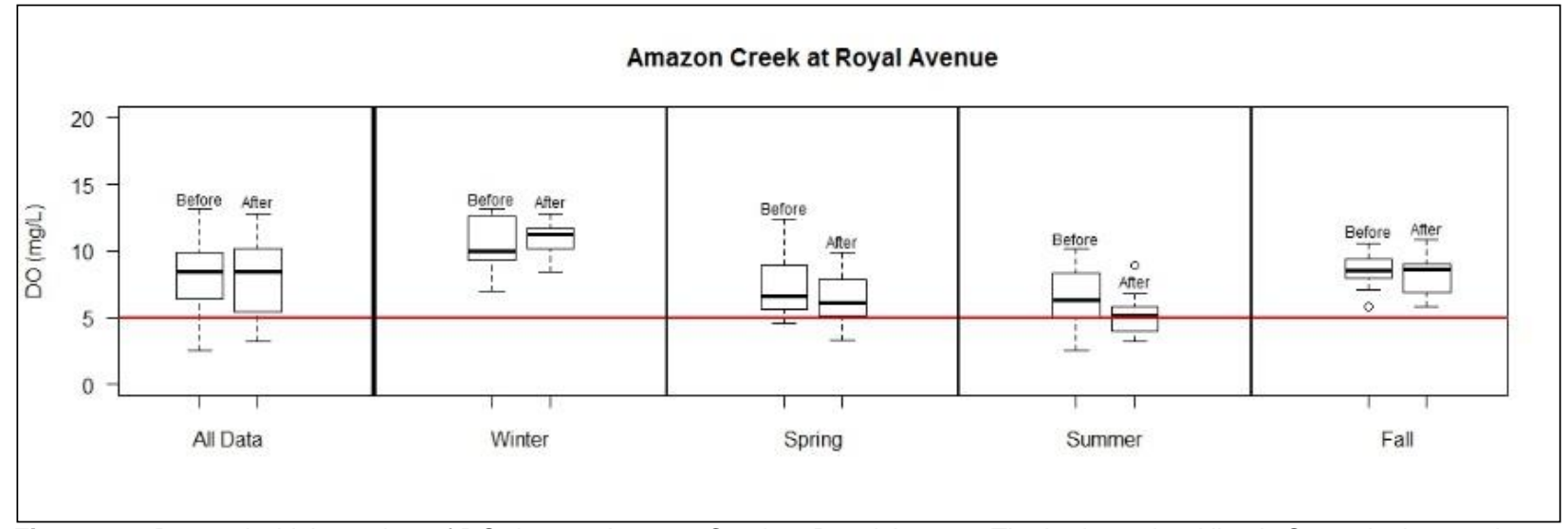

Figure 14: Box and whiskers plots of DO data on Amazon Creek at Royal Avenue. The horizontal red line is State single sample exceedance level of DO (5.0 mg/L).

Table 14: Data summaries of DO on Amazon Creek at Royal Avenue.

\begin{tabular}{|c|c|c|c|c|c|c|c|c|c|}
\hline & & $\mathbf{N}$ & Min & Q1 & Geometric Mean & Q3 & Max & $\%$ Exceeded & $\Delta \%$ Exceeded \\
\hline \multirow{2}{*}{ All Data } & Before & 64 & 2.5 & 6.4 & 8.3 & 9.8 & 13.2 & $11 \%$ & \multirow{2}{*}{$+5 \%$} \\
\hline & After & 44 & 3.2 & 5.4 & 7.9 & 10.4 & 12.8 & $16 \%$ & \\
\hline \multirow{2}{*}{ Winter } & Before & 18 & 7.0 & 9.4 & 10.5 & $\overline{12.3}$ & 13.2 & $0 \%$ & \multirow{2}{*}{$0 \%$} \\
\hline & After & 15 & 8.4 & 10.2 & 10.9 & 11.7 & 12.8 & $0 \%$ & \\
\hline \multirow{2}{*}{ Spring } & Before & 14 & 4.6 & 5.8 & 7.4 & 8.8 & 12.4 & $14 \%$ & \multirow{2}{*}{$+8 \%$} \\
\hline & After & 9 & 3.3 & 5.2 & 6.6 & 7.9 & 9.9 & $22 \%$ & \\
\hline \multirow{2}{*}{ Summer } & Before & 18 & 2.5 & 5.0 & 6.5 & 8.3 & 10.2 & $28 \%$ & \multirow{2}{*}{$+10 \%$} \\
\hline & After & 13 & 3.2 & 4.0 & 5.3 & 5.8 & 8.9 & $38 \%$ & \\
\hline \multirow{2}{*}{ Fall } & Before & 14 & 7.1 & 8.3 & 8.8 & 9.5 & 10.6 & $0 \%$ & \multirow{2}{*}{$0 \%$} \\
\hline & After & 7 & 5.8 & 6.9 & 8.1 & 9.0 & 10.9 & $0 \%$ & \\
\hline
\end{tabular}

* Bold and shaded indicate State single sample criterion exceedance

\section{Willow Creek at $18^{\text {th }}$ Avenue}




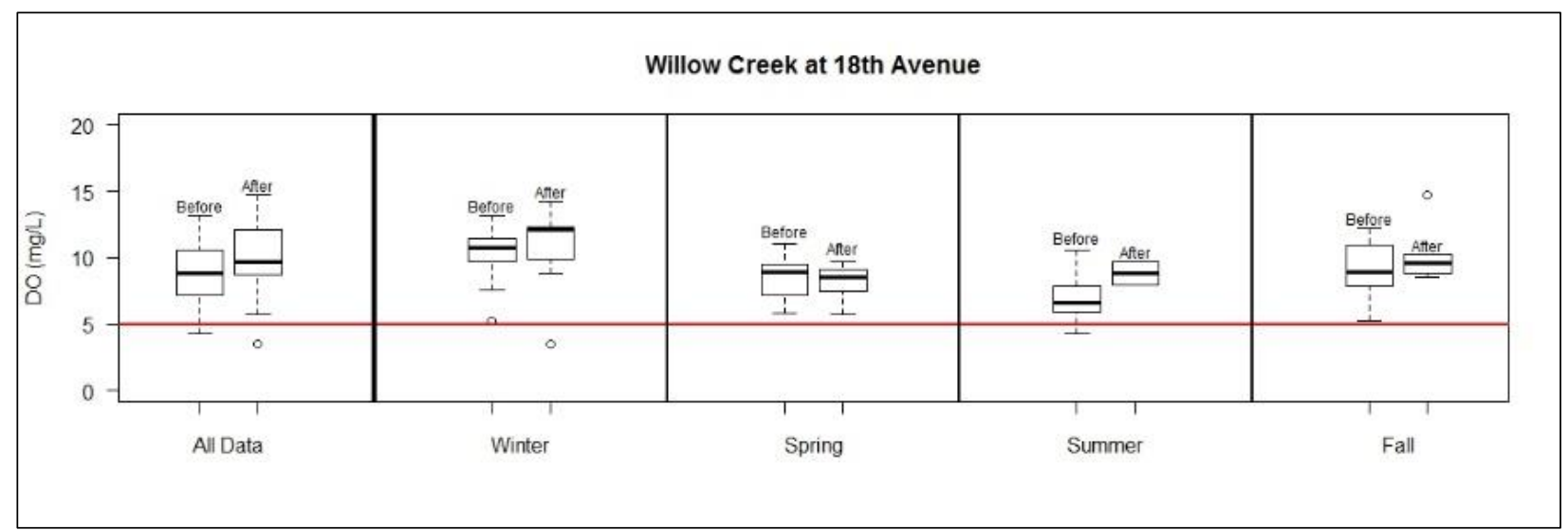

Figure 15: Box and whiskers plots of DO data on Willow Creek at 18th Avenue. The horizontal red line is State single sample exceedance level of DO (5.0 mg/L).

Table 15: Data summaries of DO on Willow Creek at 18th Avenue.

\begin{tabular}{|c|c|c|c|c|c|c|c|c|c|}
\hline & & $\mathbf{N}$ & Min & Q1 & Geometric Mean & Q3 & Max & $\%$ Exceeded & $\Delta \%$ Exceeded \\
\hline \multirow{2}{*}{ All Data } & Before & 64 & 4.3 & 7.2 & 8.8 & 10.6 & 13.2 & $2 \%$ & \multirow{2}{*}{$+1 \%$} \\
\hline & After & 31 & 3.5 & 8.8 & 10.1 & 12.2 & 14.7 & $3 \%$ & \\
\hline \multirow{2}{*}{ Winter } & Before & 18 & 5.3 & 9.9 & 10.4 & 11.4 & 13.2 & $0 \%$ & \multirow{2}{*}{$+7 \%$} \\
\hline & After & 15 & 3.5 & 9.9 & 11.2 & 12.4 & 14.2 & $7 \%$ & \\
\hline \multirow{2}{*}{ Spring } & Before & 14 & 5.8 & 7.6 & 8.7 & 9.5 & 11.1 & $0 \%$ & \multirow{2}{*}{$0 \%$} \\
\hline & After & 8 & 5.7 & 7.9 & 8.2 & 9.1 & 9.7 & $0 \%$ & \\
\hline \multirow{2}{*}{ Summer } & Before & 18 & 4.3 & 6.0 & 6.9 & 7.9 & 10.6 & $6 \%$ & \multirow{2}{*}{$-6 \%$} \\
\hline & After & 2 & 8.0 & 8.4 & 8.9 & 9.3 & 9.7 & $0 \%$ & \\
\hline \multirow{2}{*}{ Fall } & Before & 14 & 5.3 & 8.0 & 9.1 & 10.6 & 12.2 & $0 \%$ & \multirow{2}{*}{$0 \%$} \\
\hline & After & 6 & 8.5 & 9.0 & 10.3 & 10.2 & 14.7 & $0 \%$ & \\
\hline
\end{tabular}

${ }^{*}$ Bold and shaded indicate State single sample criterion exceedance

\section{Amazon Diversion Channel at Royal Avenue}

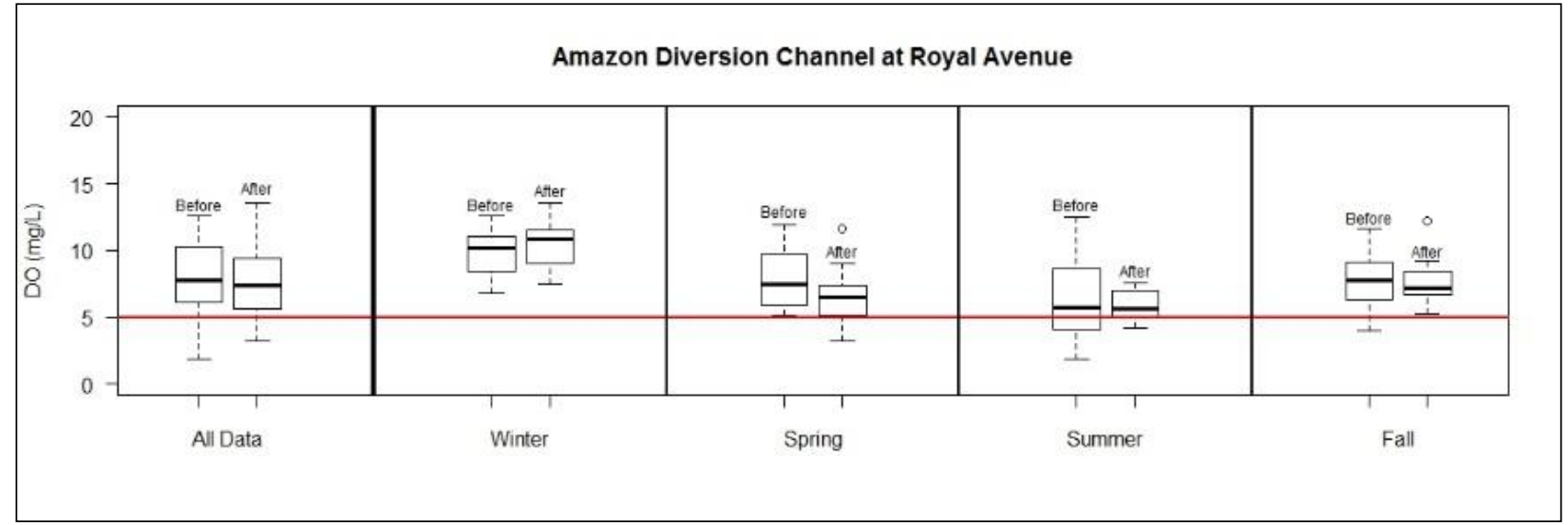

Figure 16: Box and whiskers plots of DO data on Amazon Diversion Channel at Royal Avenue. The horizontal red line is State single sample exceedance level of DO $(5.0 \mathrm{mg} / \mathrm{L})$.

Table 16: Data summaries of DO on Amazon Diversion Channel at Royal Avenue.

\begin{tabular}{|c|c|c|c|c|c|c|c|c|c|}
\hline & & $\mathbf{N}$ & Min & Q1 & Geometric Mean & Q3 & Max & $\%$ Exceeded & $\Delta \%$ Exceeded \\
\hline \multirow{2}{*}{ All Data } & Before & 64 & 1.9 & 6.2 & 8.0 & 10.3 & 12.6 & $13 \%$ & \multirow{2}{*}{$+3 \%$} \\
\hline & After & 41 & 3.2 & 5.6 & 7.9 & 9.4 & 13.6 & $10 \%$ & \\
\hline \multirow{2}{*}{ Winter } & Before & 18 & 6.8 & 8.6 & 9.8 & 11.0 & 12.6 & $0 \%$ & \multirow{2}{*}{$0 \%$} \\
\hline & After & 15 & 7.5 & 9.0 & 10.4 & 11.5 & 13.6 & $0 \%$ & \\
\hline \multirow{2}{*}{ Spring } & Before & 14 & 5.2 & 6.0 & 7.9 & 9.6 & 11.9 & $0 \%$ & \multirow{2}{*}{$+22 \%$} \\
\hline & After & 9 & 3.2 & 5.2 & 6.7 & 7.4 & 11.6 & $22 \%$ & \\
\hline
\end{tabular}




\begin{tabular}{|c|r|c|c|c|c|c|c|c|c|}
\hline \multirow{2}{*}{ Summer } & Before & 18 & $\mathbf{1 . 9}$ & $\mathbf{4 . 2}$ & 6.3 & 8.4 & 12.5 & $39 \%$ & \multirow{2}{*}{$-25 \%$} \\
\cline { 2 - 10 } & After & 14 & $\mathbf{4 . 2}$ & 5.2 & 6.0 & 6.9 & 7.6 & $14 \%$ & $7 \%$ \\
\hline \multirow{3}{*}{ Fall } & Before & 14 & 5.3 & 6.8 & 7.9 & 8.5 & 12.2 & $7 \%$ & \multirow{2}{*}{$7 \%$} \\
\cline { 2 - 10 } & After & 7 & $\mathbf{4 . 0}$ & 6.5 & 7.9 & 9.1 & 11.6 & $0 \%$ & \\
\hline
\end{tabular}

* Bold and shaded indicate State single sample criterion exceedance

\section{A-3 Drain at Terry Street}

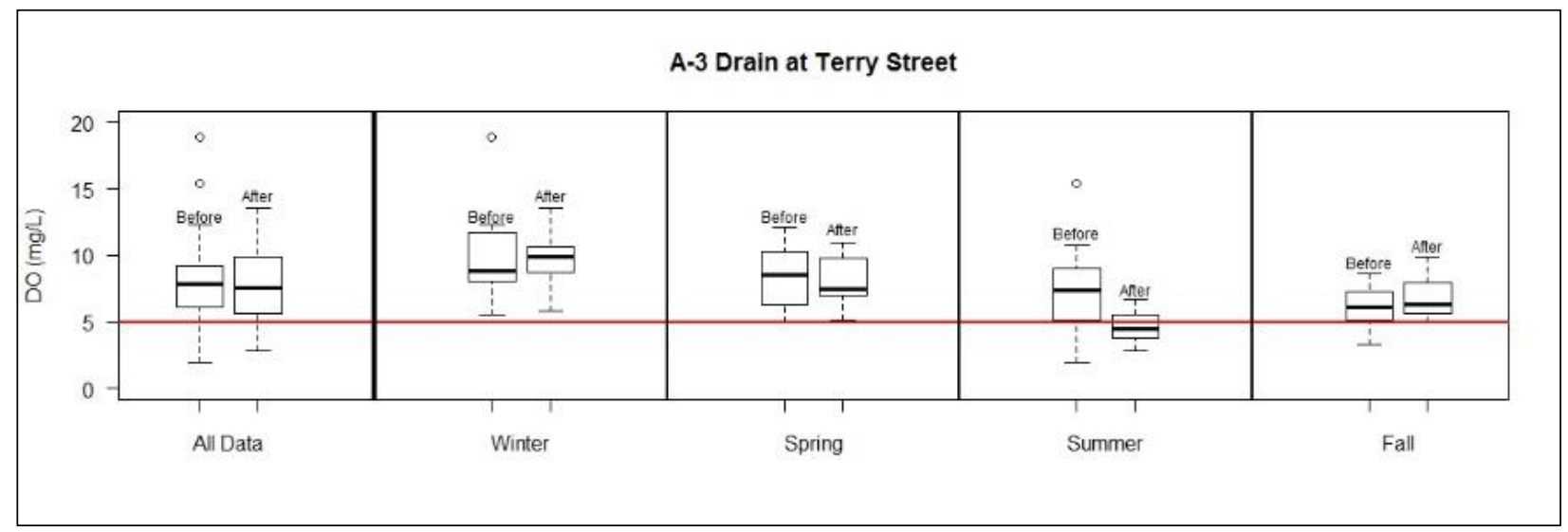

Figure 17: Box and whiskers plots of DO data on A-3 Drain at Terry Street. The horizontal red line is State single sample exceedance level of DO (5.0 mg/L).

Table 17: Data summaries of DO on A-3 Drain at Terry Street.

\begin{tabular}{|c|c|c|c|c|c|c|c|c|c|}
\hline & & $\mathbf{N}$ & Min & Q1 & Geometric Mean & Q3 & Max & $\%$ Exceeded & $\Delta \%$ Exceeded \\
\hline \multirow{2}{*}{ All Data } & Before & 43 & 2.0 & 6.1 & 8.1 & 9.2 & 18.9 & $9 \%$ & \multirow{2}{*}{$+9 \%$} \\
\hline & After & 40 & 2.8 & 5.7 & 7.7 & 9.9 & 13.6 & $18 \%$ & \\
\hline \multirow{2}{*}{ Winter } & Before & 12 & 5.5 & 8.2 & 10.0 & 11.7 & 18.9 & $0 \%$ & \multirow{2}{*}{$0 \%$} \\
\hline & After & 15 & 5.8 & 8.7 & 9.7 & 10.7 & 13.6 & $0 \%$ & \\
\hline \multirow{2}{*}{ Spring } & Before & 9 & 5.0 & 6.3 & 8.4 & 10.3 & 12.1 & $0 \%$ & \multirow{2}{*}{$0 \%$} \\
\hline & After & 9 & 5.2 & 7.0 & 8.1 & 9.8 & 11.0 & $0 \%$ & \\
\hline \multirow{2}{*}{ Summer } & Before & 12 & 2.0 & 5.2 & 7.5 & 9.0 & 15.4 & $25 \%$ & \multirow{2}{*}{$+31 \%$} \\
\hline & After & 9 & 2.8 & 3.8 & 4.6 & 5.5 & 6.7 & $56 \%$ & \\
\hline \multirow{2}{*}{ Fall } & Before & 10 & 3.3 & 5.3 & 6.2 & 7.2 & 8.6 & $10 \%$ & \multirow{2}{*}{$+19 \%$} \\
\hline & After & 7 & 5.0 & 5.6 & 6.9 & 8.0 & 9.9 & $29 \%$ & \\
\hline
\end{tabular}

* Bold and shaded indicate State single sample criterion exceedance

\section{Lower Amazon}

\section{Amazon Creek at RM 5.82}

\section{Amazon Creek at RM 5.82}

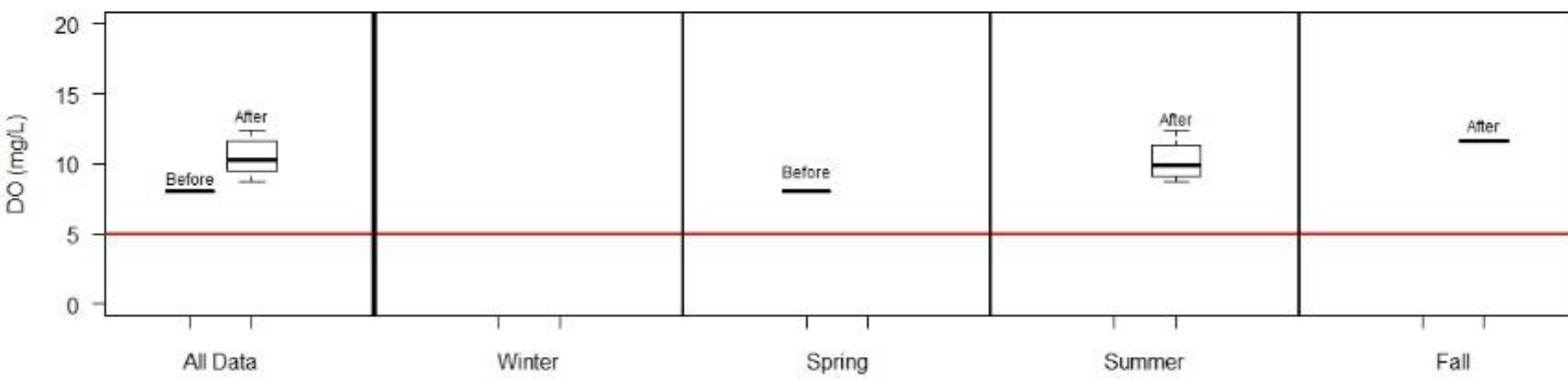


Figure 18: Box and whiskers plots of DO data on Amazon Creek at RM 5.82. The horizontal red line is State single sample exceedance level of DO (5.0 mg/L).

Table 18: Data summaries of DO on Amazon Creek at RM 5.82.

\begin{tabular}{|c|c|c|c|c|c|c|c|c|c|}
\hline & & $\mathbf{N}$ & Min & Q1 & Geometric Mean & Q3 & Max & $\%$ Exceeded & $\Delta \%$ Exceeded \\
\hline \multirow{2}{*}{ All Data } & Before & 0 & \multicolumn{6}{|c|}{$\mathrm{N} / \mathrm{A}$} & \multirow{2}{*}{$N / A$} \\
\hline & After & 6 & 8.1 & 8.9 & 10.1 & 11.3 & 12.4 & $0 \%$ & \\
\hline \multirow{2}{*}{ Winter } & Before & 0 & \multicolumn{6}{|c|}{$\mathrm{N} / \mathrm{A}$} & \multirow{2}{*}{$\mathrm{N} / \mathrm{A}$} \\
\hline & After & 0 & & & $\mathrm{~N}$ & & & & \\
\hline \multirow{2}{*}{ Spring } & Before & 0 & \multicolumn{6}{|c|}{$\mathrm{N} / \mathrm{A}$} & \multirow{2}{*}{$\mathrm{N} / \mathrm{A}$} \\
\hline & After & 1 & 8.1 & 8.1 & 8.1 & 8.1 & 8.1 & $0 \%$ & \\
\hline \multirow{2}{*}{ Summer } & Before & 0 & \multicolumn{6}{|c|}{$\mathrm{N} / \mathrm{A}$} & \multirow{2}{*}{$\mathrm{N} / \mathrm{A}$} \\
\hline & After & 4 & 8.7 & 9.3 & 10.22 & 10.8 & 12.4 & $0 \%$ & \\
\hline \multirow{2}{*}{ Fall } & Before & 0 & \multicolumn{6}{|c|}{$\mathrm{N} / \mathrm{A}$} & \multirow{2}{*}{$\mathrm{N} / \mathrm{A}$} \\
\hline & After & 1 & 11.6 & 11.6 & 11.6 & 11.6 & 11.6 & $0 \%$ & \\
\hline
\end{tabular}

* Bold and shaded indicate State single sample criterion exceedance

\section{Amazon Creek at High Pass Road}

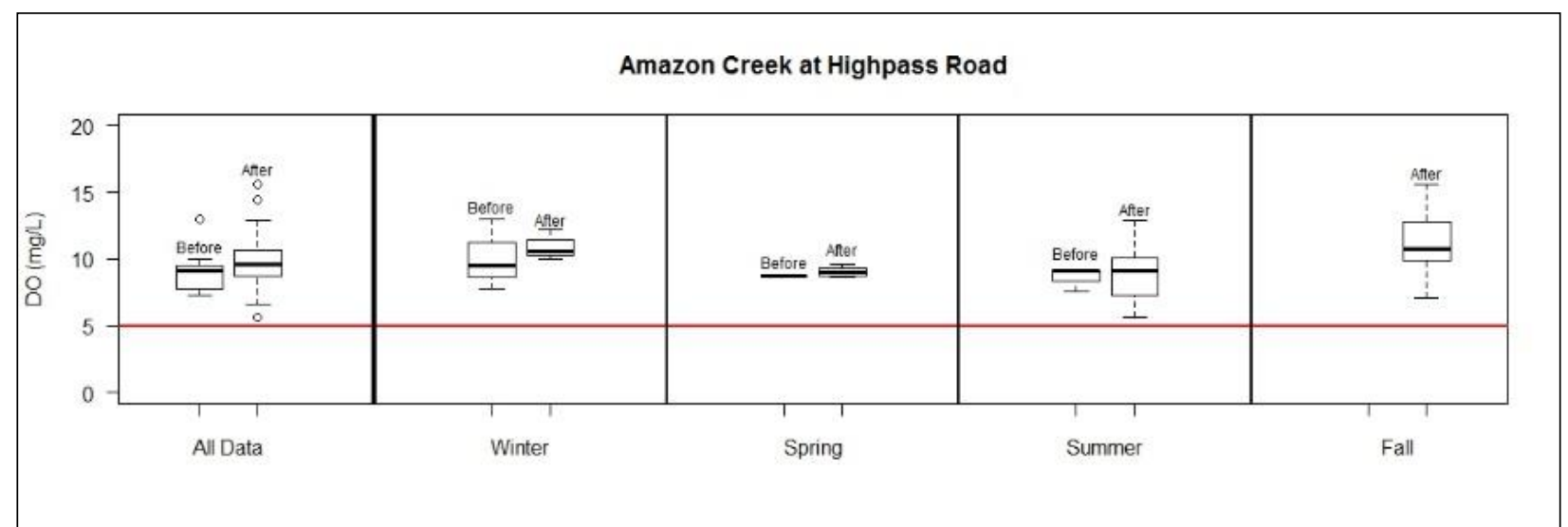

Figure 19: Box and whiskers plots of DO data on Amazon Creek at High Pass Road. The horizontal red line is State single sample exceedance level of DO (5.0 mg/L).

Table 19: Data summaries of DO on Amazon Creek at High Pass Road.

\begin{tabular}{|c|c|c|c|c|c|c|c|c|c|}
\hline & & $\mathbf{N}$ & Min & Q1 & Geometric Mean & Q3 & Max & $\%$ Exceeded & $\Delta \%$ Exceeded \\
\hline \multirow{2}{*}{ All Data } & Before & 10 & 7.3 & 8.0 & 9.2 & 9.5 & 13.0 & $0 \%$ & \multirow{2}{*}{$0 \%$} \\
\hline & After & 27 & 5.6 & 8.8 & 8.9 & 10.7 & 15.6 & $0 \%$ & \\
\hline \multirow{2}{*}{ Winter } & Before & 3 & 7.8 & 8.7 & 10.1 & 11.3 & 13.0 & $0 \%$ & \multirow{2}{*}{$0 \%$} \\
\hline & After & 4 & 10.0 & 10.4 & 10.8 & 11.0 & 12.2 & $0 \%$ & \\
\hline \multirow{2}{*}{ Spring } & Before & 3 & 8.7 & 9.1 & 9.4 & 9.8 & 10.0 & $0 \%$ & \multirow{2}{*}{$0 \%$} \\
\hline & After & 7 & 7.4 & 8.3 & 8.7 & 9.1 & 9.6 & $0 \%$ & \\
\hline \multirow{2}{*}{ Summer } & Before & 3 & 7.6 & 8.4 & 8.6 & 9.1 & 9.1 & $0 \%$ & \multirow{2}{*}{$0 \%$} \\
\hline & After & 7 & 5.6 & 7.3 & 8.9 & 10.1 & 12.9 & $0 \%$ & \\
\hline \multirow{2}{*}{ Fall } & Before & 1 & \multicolumn{6}{|c|}{$\mathrm{N} / \mathrm{A}$} & \multirow{2}{*}{$0 \%$} \\
\hline & After & 9 & 7.1 & 9.9 & 11.2 & 12.8 & 15.6 & $0 \%$ & \\
\hline
\end{tabular}

* Bold and shaded indicate State single sample criterion exceedance

\section{Coyote Creek}

\section{Coyote Creek at Hamm Road}




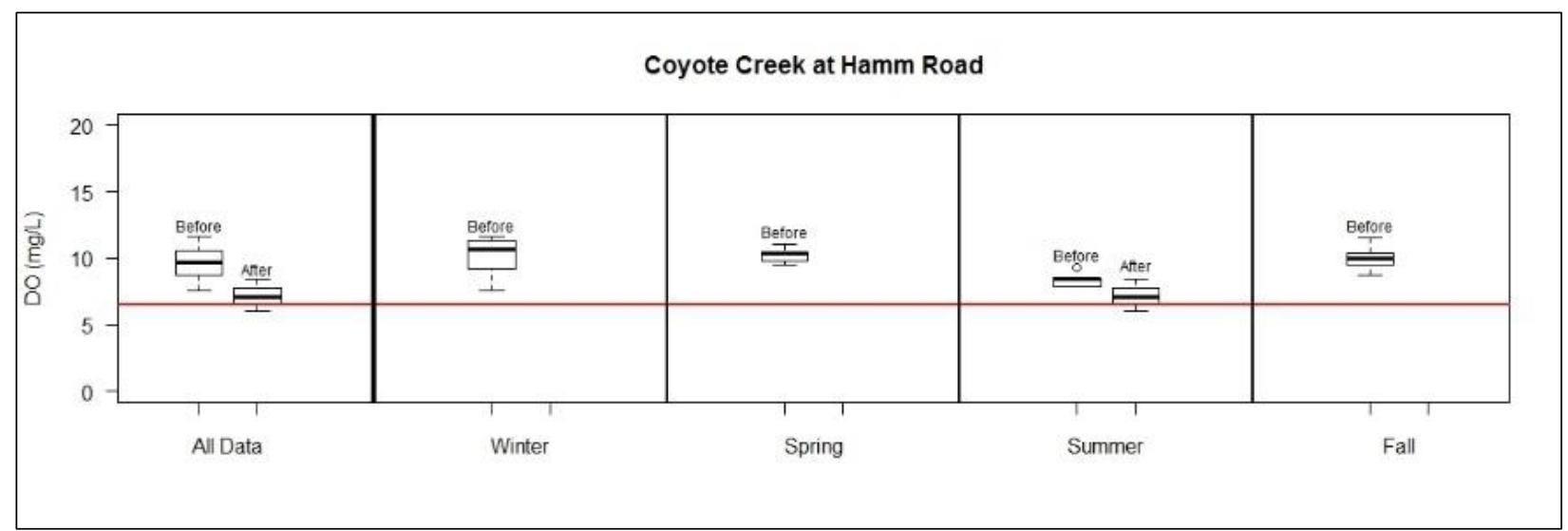

Figure 20: Box and whiskers plots of DO data on Coyote Creek at Hamm Road. The horizontal red line is State single sample exceedance level of DO (5.0 mg/L).

Table 20: Data summaries of DO on Coyote Creek at Hamm Road.

\begin{tabular}{|c|c|c|c|c|c|c|c|c|c|}
\hline & & $\mathrm{N}$ & Min & Q1 & Geometric Mean & Q3 & $\operatorname{Max}$ & $\%$ Exceeded & $\Delta \%$ Exceeded \\
\hline \multirow{2}{*}{ All Data } & Before & 22 & 7.5 & 8.8 & 9.7 & 10.5 & 11.6 & $0 \%$ & \multirow{2}{*}{$+25 \%$} \\
\hline & After & 4 & 6.0 & 6.8 & 7.2 & 7.5 & 8.4 & $25 \%$ & \\
\hline \multirow{2}{*}{ Winter } & Before & 6 & 7.5 & 9.6 & 10.2 & 1.2 & 11.6 & $0 \%$ & \multirow{2}{*}{$\mathrm{N} / \mathrm{A}$} \\
\hline & After & 0 & \multicolumn{6}{|c|}{ N/A } & \\
\hline \multirow{2}{*}{ Spring } & Before & 5 & 9.5 & 9.8 & 10.2 & 10.4 & 11.0 & $0 \%$ & \multirow{2}{*}{$\mathrm{N} / \mathrm{A}$} \\
\hline & After & 0 & \multicolumn{6}{|c|}{$\mathrm{N} / \mathrm{A}$} & \\
\hline \multirow{2}{*}{ Summer } & Before & 5 & 7.9 & 7.9 & 8.4 & 8.4 & 9.3 & $0 \%$ & \multirow{2}{*}{$+25 \%$} \\
\hline & After & 4 & 6.0 & 6.8 & 7.2 & 7.5 & 8.4 & $25 \%$ & \\
\hline \multirow{2}{*}{ Fall } & Before & 6 & 8.7 & 9.5 & 10.0 & 10.4 & 11.5 & $0 \%$ & \multirow{2}{*}{$N / A$} \\
\hline & After & 0 & \multicolumn{6}{|c|}{$\mathrm{N} / \mathrm{A}$} & \\
\hline
\end{tabular}

${ }^{*}$ Bold and shaded indicate State single sample criterion exceedance

\section{Coyote Creek at Powell Road}

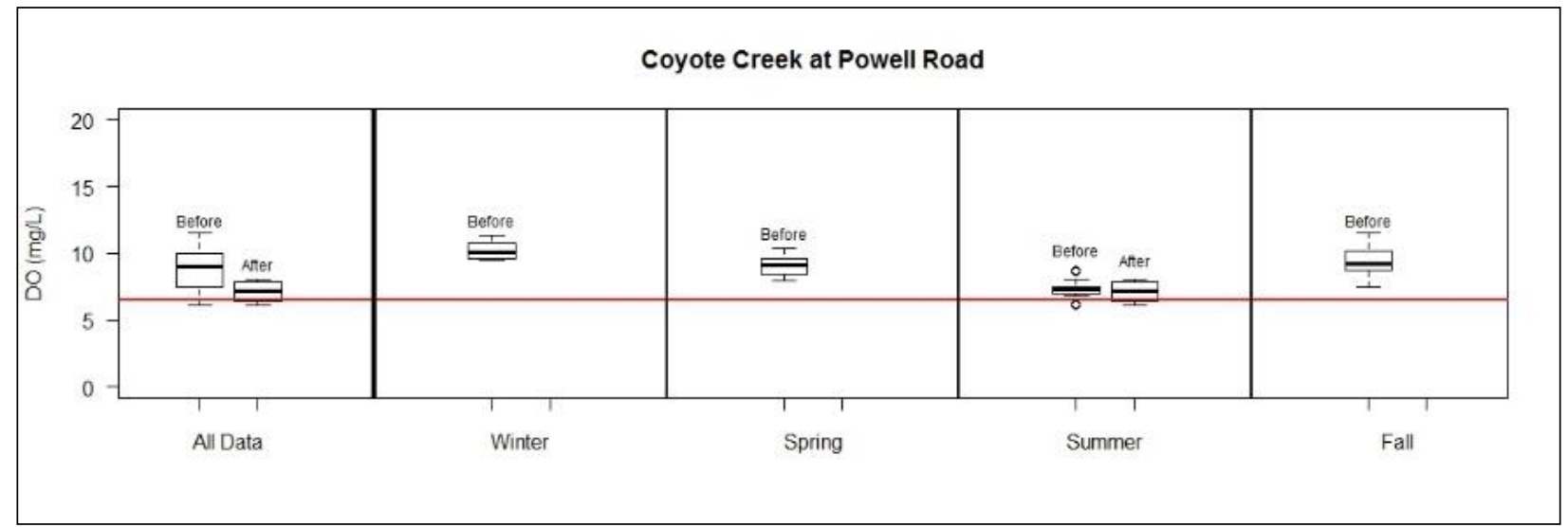

Figure 21: Box and whiskers plots of DO data on Coyote Creek at Powell Road. The horizontal red line is State single sample exceedance level of DO $(5.0 \mathrm{mg} / \mathrm{L})$.

Table 21: Data summaries of DO on Coyote Creek at Powell Road.

\begin{tabular}{|c|c|c|c|c|c|c|c|c|c|}
\hline & & $\mathbf{N}$ & Min & Q1 & Geometric Mean & Q3 & Max & $\%$ Exceeded & $\Delta \%$ Exceeded \\
\hline \multirow{2}{*}{ All Data } & Before & 39 & 6.2 & 7.5 & 8.9 & 10.0 & 11.5 & $5 \%$ & \multirow{2}{*}{$+20 \%$} \\
\hline & After & 4 & 6.1 & 6.6 & 7.1 & 7.7 & 8.1 & $25 \%$ & \\
\hline \multirow{2}{*}{ Winter } & Before & 9 & 9.5 & 9.6 & 10.2 & 10.7 & 11.3 & $0 \%$ & \multirow{2}{*}{$\mathrm{N} / \mathrm{A}$} \\
\hline & After & 0 & \multicolumn{6}{|c|}{$\mathrm{N} / \mathrm{A}$} & \\
\hline \multirow{2}{*}{ Spring } & Before & 8 & 8.0 & 8.5 & 9.1 & 9.6 & 10.4 & $0 \%$ & \multirow{2}{*}{$\mathrm{N} / \mathrm{A}$} \\
\hline & After & 0 & \multicolumn{6}{|c|}{$\mathrm{N} / \mathrm{A}$} & \\
\hline Summer & Before & 13 & 6.2 & 7.0 & 7.4 & 7.5 & 8.7 & $15 \%$ & $+10 \%$ \\
\hline
\end{tabular}




\begin{tabular}{|c|r|r|c|c|c|c|c|c|c|}
\hline & After & 4 & 6.1 & 6.6 & 7.1 & 7.7 & 8.1 & $25 \%$ & \\
\hline \multirow{3}{*}{ Fall } & Before & 9 & 7.5 & 8.7 & 9.4 & 10.2 & 11.5 & $0 \%$ & \multirow{2}{*}{ N/A } \\
\cline { 2 - 9 } & After & 0 & \multicolumn{7}{|c|}{$\mathrm{N} / \mathrm{A}$} \\
\hline
\end{tabular}

* Bold and shaded indicate State single sample criterion exceedance

\section{Coyote Creek at Petzold Road}

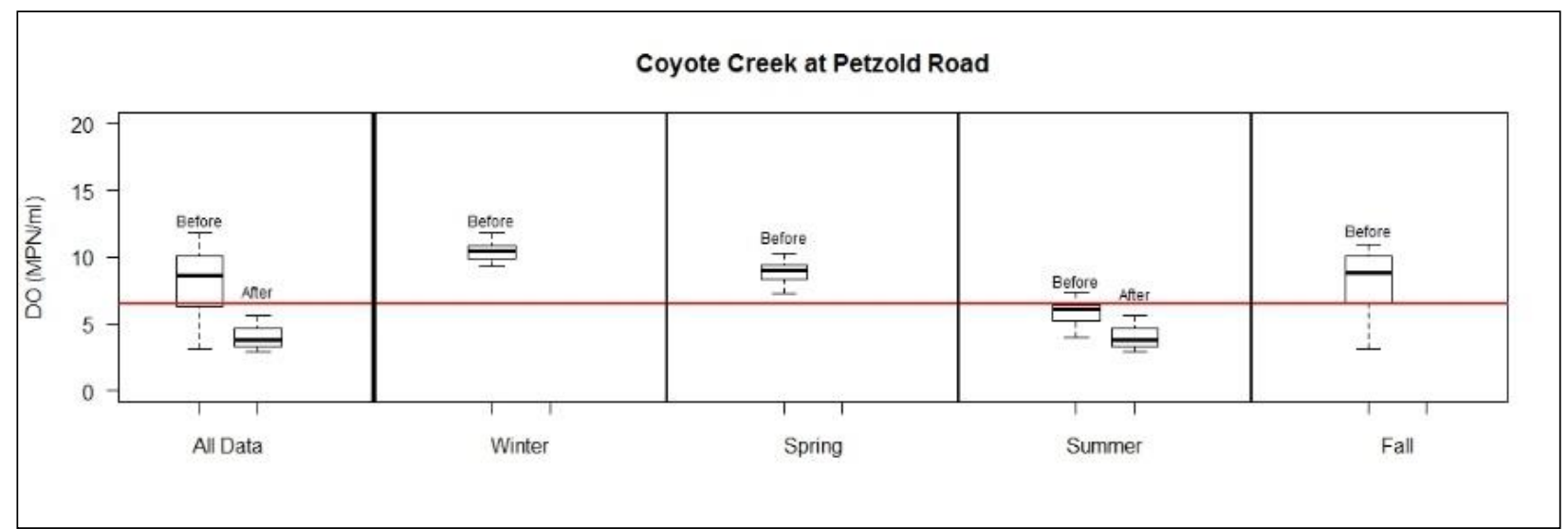

Figure 22: Box and whiskers plots of DO data on Coyote Creek at Petzold Road. The horizontal red line is State single sample exceedance level of DO $(5.0 \mathrm{mg} / \mathrm{L})$.

Table 22: Data summaries of DO on Coyote Creek at Petzold Road.

\begin{tabular}{|c|c|c|c|c|c|c|c|c|c|}
\hline & & $\mathbf{N}$ & Min & Q1 & Geometric Mean & Q3 & Max & $\%$ Exceeded & $\Delta \%$ Exceeded \\
\hline \multirow{2}{*}{ All Data } & Before & 39 & 3.2 & 6.3 & 8.2 & 10.1 & 11.8 & $33 \%$ & \multirow{2}{*}{$+67 \%$} \\
\hline & After & 3 & 2.9 & 3.4 & 4.1 & 4.7 & 5.6 & $100 \%$ & \\
\hline \multirow{2}{*}{ Winter } & Before & 9 & 9.4 & 9.9 & 10.5 & 10.8 & 11.8 & $0 \%$ & \multirow{2}{*}{$\mathrm{N} / \mathrm{A}$} \\
\hline & After & 0 & \multicolumn{6}{|c|}{$\mathrm{N} / \mathrm{A}$} & \\
\hline \multirow{2}{*}{ Spring } & Before & 8 & 7.3 & 8.5 & 8.9 & 9.4 & 10.3 & $0 \%$ & \multirow{2}{*}{$\mathrm{N} / \mathrm{A}$} \\
\hline & After & 0 & \multicolumn{6}{|c|}{$\mathrm{N} / \mathrm{A}$} & \\
\hline \multirow{2}{*}{ Summer } & Before & 12 & 4.0 & 5.4 & 5.8 & 6.4 & 7.4 & $83 \%$ & \multirow{2}{*}{$+17 \%$} \\
\hline & After & 3 & 2.9 & 3.4 & 4.1 & 4.7 & 5.6 & $100 \%$ & \\
\hline \multirow{2}{*}{ Fall } & Before & 10 & 3.2 & 6.9 & 8.3 & 10.1 & 11.0 & $30 \%$ & \multirow{2}{*}{$\mathrm{N} / \mathrm{A}$} \\
\hline & After & 0 & \multicolumn{6}{|c|}{$\mathrm{N} / \mathrm{A}$} & \\
\hline
\end{tabular}

${ }^{*}$ Bold and shaded indicate State single sample criterion exceedance 


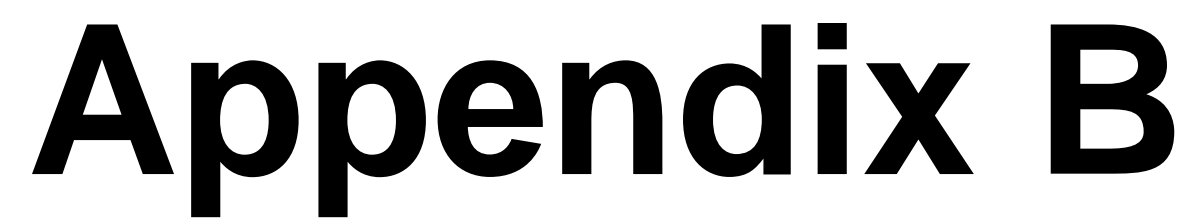

Fisher Exact Test for Independence 


\section{Bacteria (E. coli)}

\section{Before 2008}

Table 1: Fisher exact test for seasonal dependence of $E$. coli exceeding single sample standards before 2008

\begin{tabular}{|c|c|c|c|c|c|c|c|c|c|c|c|}
\hline & \multicolumn{6}{|c|}{ Upper Amazon } & \multicolumn{2}{|c|}{$\begin{array}{c}\text { Lower } \\
\text { Amazon }\end{array}$} & \multicolumn{3}{|c|}{ Coyote Creek } \\
\hline & $\begin{array}{l}29^{\text {th }} \\
\text { Ave. }\end{array}$ & $\begin{array}{c}\text { RR } \\
\text { Cross }\end{array}$ & $\begin{array}{c}\text { Royal } \\
\text { Ave. }\end{array}$ & Willow & $\begin{array}{c}\text { Div. } \\
\text { Chan. }\end{array}$ & $\begin{array}{c}\text { A-3 } \\
\text { Drain }\end{array}$ & $\begin{array}{l}\text { RM } \\
5.82\end{array}$ & $\begin{array}{c}\text { High } \\
\text { Pass } \\
\text { Rd. }\end{array}$ & $\begin{array}{c}\text { Hamm } \\
\text { Rd. }\end{array}$ & $\begin{array}{c}\text { Powell } \\
\text { Rd. }\end{array}$ & $\begin{array}{c}\text { Petzold } \\
\text { Rd. }\end{array}$ \\
\hline Exceeds & 38 & 12 & 24 & 6 & 18 & 17 & 0 & 10 & 2 & 6 & 8 \\
\hline Winter & 8 & 2 & 2 & 0 & 2 & 1 & 0 & 3 & 0 & 0 & 2 \\
\hline Summer & 12 & 1 & 11 & 1 & 11 & 8 & 0 & 2 & 2 & 0 & 0 \\
\hline Fall & 9 & 3 & 6 & 2 & 3 & 3 & 0 & 3 & 0 & 2 & 3 \\
\hline $\begin{array}{c}\text { Not } \\
\text { Exceed }\end{array}$ & 27 & 34 & 41 & 58 & 46 & 27 & 0 & 42 & 26 & 53 & 47 \\
\hline Winter & 10 & 10 & 16 & 18 & 16 & 11 & 0 & 7 & 3 & 10 & 8 \\
\hline Spring & 5 & 4 & 9 & 11 & 11 & 4 & 0 & 13 & 10 & 13 & 14 \\
\hline Fall & 5 & 8 & 8 & 12 & 11 & 7 & 0 & 10 & 4 & 11 & 10 \\
\hline
\end{tabular}

* BOLD and shaded indicates significant seasonal difference

\section{After 2008}

Table 2: $\quad$ Fisher exact test for seasonal dependence of $E$. coli exceeding single sample standards after 2008

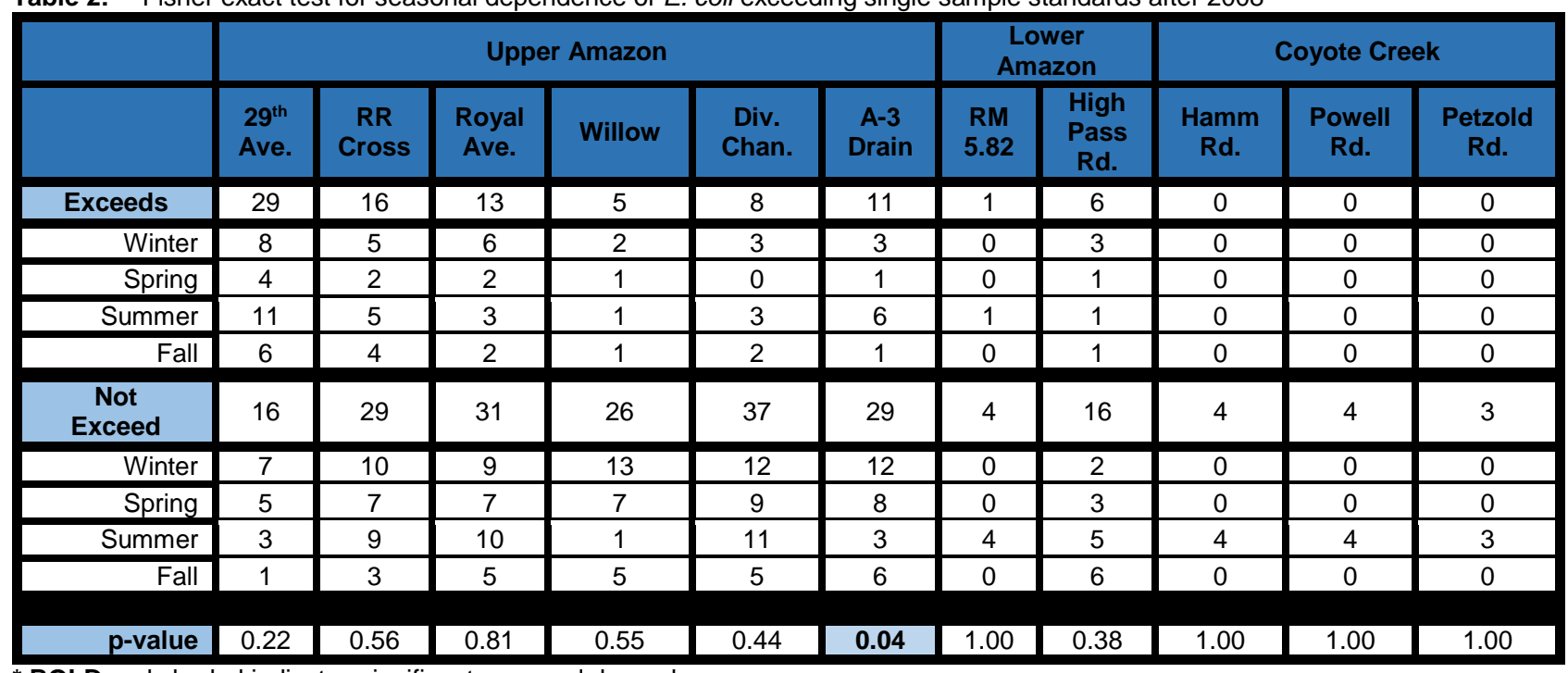

* BOLD and shaded indicates significant seasonal dependence 


\section{Dissolved Oxygen}

\section{Before 2008}

Table 3: Fisher exact test for seasonal dependence of DO exceeding load capacity before 2008

\begin{tabular}{|c|c|c|c|c|c|c|c|c|c|c|c|}
\hline & \multicolumn{6}{|c|}{ Upper Amazon } & \multicolumn{2}{|c|}{$\begin{array}{l}\text { Lower } \\
\text { Amazon }\end{array}$} & \multicolumn{3}{|c|}{ Coyote Creek } \\
\hline & $\begin{array}{l}29^{\text {th }} \\
\text { Ave. }\end{array}$ & $\begin{array}{c}\text { RR } \\
\text { Cross }\end{array}$ & $\begin{array}{c}\text { Royal } \\
\text { Ave. }\end{array}$ & Willow & $\begin{array}{l}\text { Div. } \\
\text { Chan. }\end{array}$ & $\begin{array}{c}\text { A-3 } \\
\text { Drain }\end{array}$ & $\begin{array}{l}\text { RM } \\
5.82\end{array}$ & $\begin{array}{c}\text { High } \\
\text { Pass } \\
\text { Rd. }\end{array}$ & $\begin{array}{l}\text { Hamm } \\
\text { Rd. }\end{array}$ & $\begin{array}{l}\text { Powell } \\
\text { Rd. }\end{array}$ & $\begin{array}{l}\text { Petzold } \\
\text { Rd. }\end{array}$ \\
\hline Exceeds & 3 & 10 & 7 & 1 & 8 & 4 & 0 & 0 & 0 & 2 & 13 \\
\hline Winter & 0 & 0 & 0 & 0 & 0 & 0 & 0 & 0 & 0 & 0 & 0 \\
\hline Spring & 0 & 4 & 2 & 0 & 0 & 0 & 0 & 0 & 0 & 0 & 0 \\
\hline Summer & 3 & 5 & 5 & 1 & 7 & 3 & 0 & 0 & 0 & 2 & 10 \\
\hline Fall & 0 & 1 & 0 & 0 & 1 & 1 & 0 & 0 & 0 & 0 & 3 \\
\hline $\begin{array}{c}\text { Not } \\
\text { Exceed }\end{array}$ & 62 & 36 & 57 & 63 & 56 & 39 & 0 & 10 & 22 & 37 & 26 \\
\hline Winter & 18 & 12 & 18 & 18 & 18 & 12 & 0 & 3 & 6 & 9 & 9 \\
\hline Spring & 14 & 6 & 12 & 14 & 14 & 9 & 0 & 3 & 5 & 8 & 8 \\
\hline Summer & 16 & 8 & 13 & 17 & 11 & 9 & 0 & 3 & 5 & 11 & 2 \\
\hline Fall & 14 & 10 & 14 & 14 & 13 & 9 & 0 & 1 & 6 & 9 & 7 \\
\hline p-value & 0.06 & 0.02 & 0.02 & 1.00 & 0.01 & 0.15 & 1.00 & 1.00 & 1.00 & 0.43 & 0.01 \\
\hline
\end{tabular}

${ }^{\star}$ BOLD and shaded indicates significant seasonal dependence

\section{After 2008}

Table 4: Fisher exact test for seasonal dependence of DO exceeding load capacity after 2008

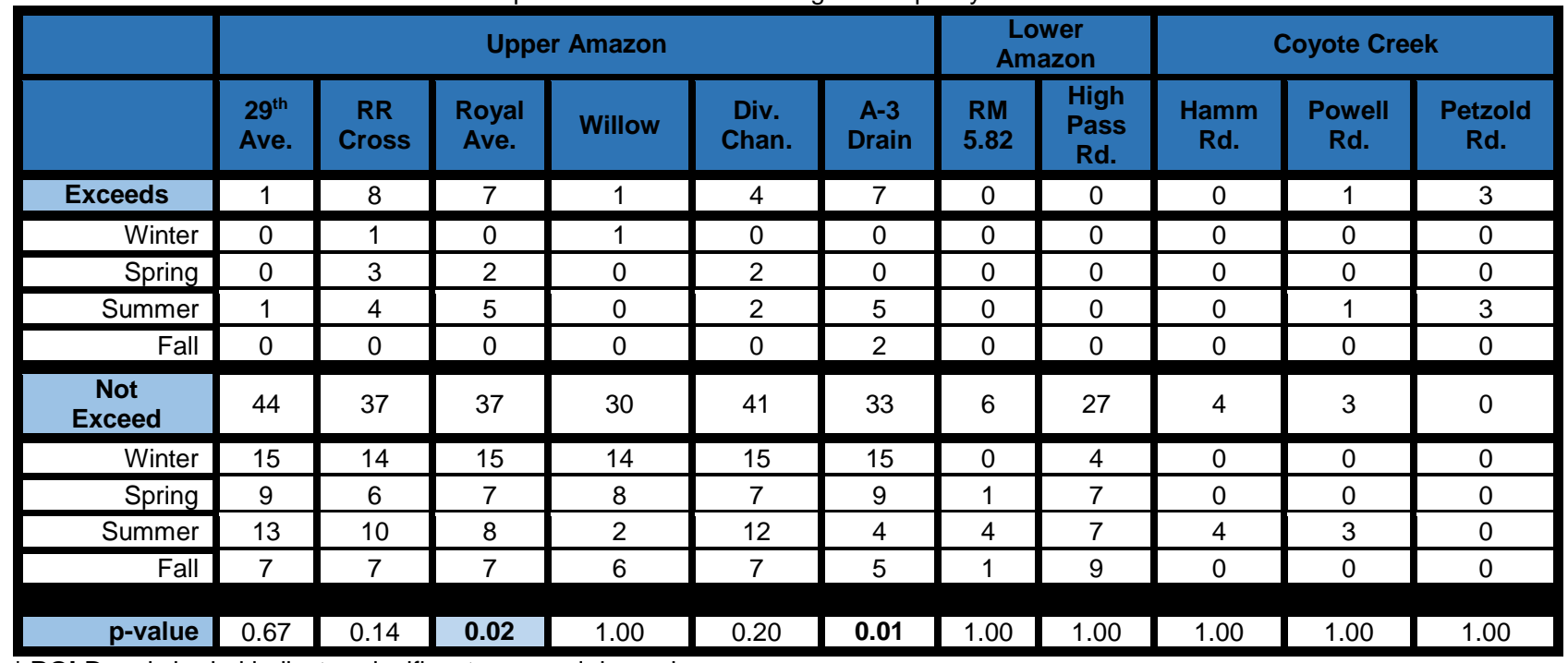

${ }^{*}$ BOLD and shaded indicates significant seasonal dependence 


\section{Appendix C Wilcoxon rank-sum test Statistics/Summaries}




\section{Bacteria (E. coli)}

\section{Upper Amazon}

\section{Amazon Creek at $\mathbf{2 9}^{\text {th }}$ Avenue}

Table 1: Amazon Creek at $29^{\text {th }}$ Avenue E. coli Two-Sample Wilcoxon rank-sum test statistics of means, before and after 2008

\begin{tabular}{|c|c|c|c|}
\hline & Geometric Mean & Wilcoxon test statistic, W & p-value \\
\hline \multicolumn{4}{|l|}{ All Data } \\
\hline Before & 738 & \multirow{2}{*}{1594} & \multirow{2}{*}{0.43} \\
\hline After & 764 & & \\
\hline \multicolumn{4}{|l|}{ Winter } \\
\hline Before & 600 & \multirow{2}{*}{137} & \multirow{2}{*}{0.96} \\
\hline After & 672 & & \\
\hline \multicolumn{4}{|l|}{ Spring } \\
\hline Before & 634 & \multirow{2}{*}{62} & \multirow{2}{*}{0.97} \\
\hline After & 592 & & \\
\hline \multicolumn{4}{|l|}{ Summer } \\
\hline Before & 825 & \multirow{2}{*}{170} & \multirow{2}{*}{0.18} \\
\hline After & 914 & & \\
\hline \multicolumn{4}{|l|}{ Fall } \\
\hline Before & 900 & \multirow{2}{*}{56} & \multirow{2}{*}{0.63} \\
\hline After & 881 & & \\
\hline
\end{tabular}

* BOLD and shaded indicates significance

\section{Amazon Creek at Railroad Crossing}

Table 2: Amazon Creek at Railroad Crossing E. coli Wilcoxon rank-sum test statistics of means, before and after 2008

\begin{tabular}{|c|c|c|c|}
\hline & Geometric Mean & Wilcoxon test statistic, W & p-value \\
\hline \multicolumn{4}{|l|}{ All Data } \\
\hline Before & 378 & \multirow{2}{*}{1068} & \multirow{2}{*}{0.80} \\
\hline After & 420 & & \\
\hline \multicolumn{4}{|l|}{ Winter } \\
\hline Before & 276 & \multirow{2}{*}{98} & \multirow{2}{*}{0.73} \\
\hline After & 335 & & \\
\hline \multicolumn{4}{|l|}{ Spring } \\
\hline Before & 595 & \multirow{2}{*}{31} & \multirow{2}{*}{0.25} \\
\hline After & 466 & & \\
\hline \multicolumn{4}{|l|}{ Summer } \\
\hline Before & 285 & \multirow{2}{*}{96} & \multirow{2}{*}{0.85} \\
\hline After & 414 & & \\
\hline \multicolumn{4}{|l|}{ Fall } \\
\hline Before & 404 & \multirow{2}{*}{54} & \multirow{2}{*}{0.18} \\
\hline After & 553 & & \\
\hline
\end{tabular}

* BOLD and shaded indicates significance

\section{Amazon Creek at Royal Avenue}

Table 3: Amazon Creek at Royal Avenue E. coli Wilcoxon rank-sum test statistics of means, before and after 2008

\begin{tabular}{|c|c|c|c|}
\hline & Geometric Mean & Wilcoxon test statistic, W & $p$-value \\
\hline \multicolumn{4}{|l|}{ All Data } \\
\hline Before & 461 & 1202 & 050 \\
\hline After & 403 & 1322 & 0.50 \\
\hline
\end{tabular}




\begin{tabular}{|c|c|c|c|}
\hline Winter & & & \\
\hline Before & 186 & \multirow{2}{*}{160} & \multirow{2}{*}{0.39} \\
\hline After & 455 & & \\
\hline \multicolumn{4}{|l|}{ Spring } \\
\hline Before & 457 & \multirow{2}{*}{47} & \multirow{2}{*}{0.31} \\
\hline After & 288 & & \\
\hline \multicolumn{4}{|l|}{ Summer } \\
\hline Before & 603 & \multirow{2}{*}{77} & \multirow{2}{*}{0.08} \\
\hline After & 440 & & \\
\hline \multicolumn{4}{|l|}{ Fall } \\
\hline Before & 596 & \multirow{2}{*}{56} & \multirow{2}{*}{0.65} \\
\hline After & 424 & & \\
\hline
\end{tabular}

* BOLD and shaded indicates significance

\section{Willow Creek at $18^{\text {th }}$ Avenue}

Table 4: Willow Creek at $18^{\text {th }}$ Avenue E. coli Wilcoxon rank-sum test statistics of means, before and after 2008

\begin{tabular}{|c|c|c|c|}
\hline & Geometric Mean & Wilcoxon test statistic, W & p-value \\
\hline \multicolumn{4}{|l|}{ All Data } \\
\hline Before & 125 & \multirow{2}{*}{1106} & \multirow{2}{*}{0.44} \\
\hline After & 199 & & \\
\hline \multicolumn{4}{|l|}{ Winter } \\
\hline Before & 40 & \multirow{2}{*}{123} & \multirow{2}{*}{0.80} \\
\hline After & 170 & & \\
\hline \multicolumn{4}{|l|}{ Spring } \\
\hline Before & 270 & \multirow{2}{*}{46} & \multirow{2}{*}{0.49} \\
\hline After & 133 & & \\
\hline \multicolumn{4}{|l|}{ Summer } \\
\hline $\begin{array}{r}\text { Before } \\
\text { After }\end{array}$ & \multicolumn{3}{|c|}{$\mathrm{N} / \mathrm{A}$} \\
\hline \multicolumn{4}{|l|}{ Fall } \\
\hline Before & 147 & \multirow{2}{*}{47} & \multirow{2}{*}{0.72} \\
\hline After & 161 & & \\
\hline
\end{tabular}

* BOLD and shaded indicates significance

\section{Amazon Diversion Channel at Royal Avenue}

Table 5: Amazon Diversion Channel at Royal Avenue E. coli Two-Sample t-test statistics of means, before and after 2008

\begin{tabular}{|c|c|c|c|}
\hline & Geometric Mean & Wilcoxon test statistic, W & p-value \\
\hline \multicolumn{4}{|l|}{ All Data } \\
\hline Before & 344 & \multirow{2}{*}{1296} & \multirow{2}{*}{0.31} \\
\hline After & 252 & & \\
\hline \multicolumn{4}{|l|}{ Winter } \\
\hline Before & 119 & \multirow{2}{*}{146} & \multirow{2}{*}{0.70} \\
\hline After & 177 & & \\
\hline \multicolumn{4}{|l|}{ Spring } \\
\hline Before & 188 & \multirow{2}{*}{63} & \multirow{2}{*}{0.81} \\
\hline After & 70 & & \\
\hline \multicolumn{4}{|l|}{ Summer } \\
\hline Before & 674 & \multirow{2}{*}{70} & \multirow{2}{*}{0.02} \\
\hline After & 404 & & \\
\hline \multicolumn{4}{|l|}{ Fall } \\
\hline Before & 356 & \multirow{2}{*}{59} & \multirow{2}{*}{0.48} \\
\hline After & 341 & & \\
\hline
\end{tabular}

* BOLD and shaded indicates significance 


\section{A-3 Drain at Terry Street}

Table 6: A-3 Drain at Terry Street E. coli Wilcoxon rank-sum test statistics of means, before and after 2008

\begin{tabular}{|c|c|c|c|}
\hline & Geometric Mean & Wilcoxon test statistic, W & $p$-value \\
\hline \multicolumn{4}{|l|}{ All Data } \\
\hline Before & 702 & \multirow{2}{*}{734} & \multirow{2}{*}{0.20} \\
\hline After & 350 & & \\
\hline \multicolumn{4}{|l|}{ Winter } \\
\hline Before & 140 & \multirow{2}{*}{72} & \multirow{2}{*}{0.39} \\
\hline After & 160 & & \\
\hline \multicolumn{4}{|l|}{ Spring } \\
\hline Before & 939 & \multirow{2}{*}{28} & \multirow{2}{*}{0.29} \\
\hline After & 299 & & \\
\hline \multicolumn{4}{|l|}{ Summer } \\
\hline Before & 1264 & \multirow{2}{*}{52} & \multirow{2}{*}{0.69} \\
\hline After & 836 & & \\
\hline \multicolumn{4}{|l|}{ Fall } \\
\hline Before & 325 & \multirow{2}{*}{44} & \multirow{2}{*}{0.43} \\
\hline After & 242 & & \\
\hline
\end{tabular}

* BOLD and shaded indicates significance

\section{Lower Amazon}

\section{Amazon Creek at RM 5.82}

Table 7: Amazon Creek at RM 5.82 E. coli Wilcoxon rank-sum test statistics of means, before and after 2008

\begin{tabular}{|c|c|c|c|}
\hline & Geometric Mean & Wilcoxon test statistic, W & p-value \\
\hline \multicolumn{4}{|l|}{ All Data } \\
\hline $\begin{array}{r}\text { Before } \\
\text { After }\end{array}$ & & $\mathrm{N} / \mathrm{A}$ & \\
\hline \multicolumn{4}{|l|}{ Winter } \\
\hline $\begin{array}{r}\text { Before } \\
\text { After }\end{array}$ & & $\mathrm{N} / \mathrm{A}$ & \\
\hline \multicolumn{4}{|l|}{ Spring } \\
\hline $\begin{array}{r}\text { Before } \\
\text { After }\end{array}$ & & $\mathrm{N} / \mathrm{A}$ & \\
\hline \multicolumn{4}{|l|}{ Summer } \\
\hline $\begin{array}{r}\text { Before } \\
\text { After }\end{array}$ & & $\mathrm{N} / \mathrm{A}$ & \\
\hline \multicolumn{4}{|l|}{ Fall } \\
\hline $\begin{array}{r}\text { Before } \\
\text { After }\end{array}$ & & $\mathrm{N} / \mathrm{A}$ & \\
\hline
\end{tabular}

${ }^{\star}$ BOLD and shaded indicates significance

\section{Amazon Creek at High Pass Road}

Table 8: Amazon Creek at High Pass Road E. coli Wilcoxon rank-sum test statistics of means, before and after 2008

\begin{tabular}{|c|c|c|c|}
\hline & Geometric Mean & Wilcoxon test statistic, W & p-value \\
\hline \multicolumn{4}{|l|}{ All Data } \\
\hline Before & 306 & \multirow{2}{*}{577} & \multirow{2}{*}{0.48} \\
\hline After & 276 & & \\
\hline \multicolumn{4}{|l|}{ Winter } \\
\hline Before & 394 & \multirow{2}{*}{10} & \multirow{2}{*}{0.47} \\
\hline After & 190 & & \\
\hline
\end{tabular}




\begin{tabular}{|c|c|c|c|}
\hline Spring & & & \\
\hline Before & 257 & \multirow{2}{*}{41} & \multirow{2}{*}{0.31} \\
\hline After & 218 & & \\
\hline \multicolumn{4}{|l|}{ Summer } \\
\hline Before & 167 & \multirow{2}{*}{56} & \multirow{2}{*}{0.28} \\
\hline After & 244 & & \\
\hline \multicolumn{4}{|l|}{ Fall } \\
\hline Before & 443 & \multirow{2}{*}{46} & \multirow{2}{*}{0.82} \\
\hline After & 374 & & \\
\hline
\end{tabular}

* BOLD and shaded indicates significance

\section{Coyote Creek}

\section{Coyote Creek at Hamm Road}

Table 9: Coyote Creek at Hamm Road E. coli Wilcoxon rank-sum test statistics of means, before and after 2008

\begin{tabular}{|c|c|c|c|}
\hline & Geometric Mean & Wilcoxon test statistic, W & p-value \\
\hline \multicolumn{4}{|l|}{ All Data } \\
\hline $\begin{array}{r}\text { Before } \\
\text { After }\end{array}$ & \multicolumn{3}{|c|}{$\mathrm{N} / \mathrm{A}$} \\
\hline \multicolumn{4}{|l|}{ Winter } \\
\hline $\begin{array}{r}\text { Before } \\
\text { After }\end{array}$ & \multicolumn{3}{|c|}{$\mathrm{N} / \mathrm{A}$} \\
\hline \multicolumn{4}{|l|}{ Spring } \\
\hline $\begin{array}{r}\text { Before } \\
\text { After }\end{array}$ & \multicolumn{3}{|c|}{$\mathrm{N} / \mathrm{A}$} \\
\hline \multicolumn{4}{|l|}{ Summer } \\
\hline Before & 172 & \multirow{2}{*}{25} & \multirow{2}{*}{0.74} \\
\hline After & 84 & & \\
\hline \multicolumn{4}{|l|}{ Fall } \\
\hline $\begin{array}{r}\text { Before } \\
\text { After }\end{array}$ & & $\mathrm{N} / \mathrm{A}$ & \\
\hline
\end{tabular}

* BOLD and shaded indicates significance

\section{Coyote Creek at Powell Road}

Table 10: Coyote Creek at Powell Road E. coli Wilcoxon rank-sum test statistics of means, before and after 2008

\begin{tabular}{|c|c|c|c|}
\hline & Geometric Mean & Wilcoxon test statistic, W & $p$-value \\
\hline \multicolumn{4}{|l|}{ All Data } \\
\hline $\begin{array}{r}\text { Before } \\
\text { After }\end{array}$ & \multicolumn{3}{|c|}{$\mathrm{N} / \mathrm{A}$} \\
\hline \multicolumn{4}{|l|}{ Winter } \\
\hline $\begin{array}{r}\text { Before } \\
\text { After }\end{array}$ & \multicolumn{3}{|c|}{$\mathrm{N} / \mathrm{A}$} \\
\hline \multicolumn{4}{|l|}{ Spring } \\
\hline $\begin{array}{r}\text { Before } \\
\text { After }\end{array}$ & \multicolumn{3}{|c|}{$\mathrm{N} / \mathrm{A}$} \\
\hline \multicolumn{4}{|l|}{ Summer } \\
\hline Before & 117 & \multirow{2}{*}{42} & \multirow{2}{*}{0.78} \\
\hline After & 103 & & \\
\hline \multicolumn{4}{|l|}{ Fall } \\
\hline $\begin{array}{r}\text { Before } \\
\text { After }\end{array}$ & & $\mathrm{N} / \mathrm{A}$ & \\
\hline
\end{tabular}

* BOLD and shaded indicates significance 


\section{Coyote Creek at Petzold Road}

Table 11: Coyote Creek at Petzold Road E. coli Wilcoxon rank-sum test statistics of means, before and after 2008

\begin{tabular}{|c|c|c|c|}
\hline & Geometric Mean & Wilcoxon test statistic, W & $\mathrm{p}$-value \\
\hline \multicolumn{4}{|l|}{ All Data } \\
\hline $\begin{array}{r}\text { Before } \\
\text { After }\end{array}$ & \multicolumn{3}{|c|}{$\mathrm{N} / \mathrm{A}$} \\
\hline \multicolumn{4}{|l|}{ Winter } \\
\hline $\begin{array}{r}\text { Before } \\
\text { After }\end{array}$ & \multicolumn{3}{|c|}{$\mathrm{N} / \mathrm{A}$} \\
\hline \multicolumn{4}{|l|}{ Spring } \\
\hline $\begin{array}{r}\text { Before } \\
\text { After }\end{array}$ & \multicolumn{3}{|c|}{$\mathrm{N} / \mathrm{A}$} \\
\hline \multicolumn{4}{|l|}{ Summer } \\
\hline Before & 72 & \multirow{2}{*}{30} & \multirow{2}{*}{0.54} \\
\hline After & 161 & & \\
\hline \multicolumn{4}{|l|}{ Fall } \\
\hline $\begin{array}{r}\text { Before } \\
\text { After }\end{array}$ & & $\mathrm{N} / \mathrm{A}$ & \\
\hline
\end{tabular}

* BOLD and shaded indicates significance 


\section{Dissolved Oxygen}

\section{Upper Amazon}

\section{Amazon Creek at 29 $^{\text {th }}$ Avenue}

Table 12: Amazon Creek at $29^{\text {th }}$ Avenue DO Wilcoxon rank-sum test statistics of means, before and after 2008

\begin{tabular}{|c|c|c|c|}
\hline & Geometric Mean & Wilcoxon test statistic, W & p-value \\
\hline \multicolumn{4}{|l|}{ All Data } \\
\hline Before & 8.91 & \multirow{2}{*}{1644} & \multirow{2}{*}{0.27} \\
\hline After & 9.59 & & \\
\hline \multicolumn{4}{|l|}{ Winter } \\
\hline Before & 11.14 & \multirow{2}{*}{177} & \multirow{2}{*}{0.13} \\
\hline After & 11.47 & & \\
\hline \multicolumn{4}{|l|}{ Spring } \\
\hline Before & 9.50 & \multirow{2}{*}{65} & \multirow{2}{*}{0.95} \\
\hline After & 9.64 & & \\
\hline \multicolumn{4}{|l|}{ Summer } \\
\hline Before & 6.08 & \multirow{2}{*}{185} & \multirow{2}{*}{0.06} \\
\hline After & 7.09 & & \\
\hline \multicolumn{4}{|l|}{ Fall } \\
\hline Before & 9.31 & \multirow{2}{*}{67} & \multirow{2}{*}{0.20} \\
\hline After & 10.49 & & \\
\hline
\end{tabular}

${ }^{*}$ BOLD and shaded indicates significance

\section{Amazon Creek at Railroad Crossing}

Table 13: Amazon Creek at Railroad Crossing DO Wilcoxon rank-sum test statistics of means, before and after 2008

\begin{tabular}{|c|c|c|c|}
\hline & Geometric Mean & Wilcoxon test statistic, W & $p$-value \\
\hline \multicolumn{4}{|l|}{ All Data } \\
\hline Before & 7.73 & \multirow{2}{*}{1440} & \multirow{2}{*}{0.01} \\
\hline After & 7.98 & & \\
\hline \multicolumn{4}{|l|}{ Winter } \\
\hline Before & 9.68 & \multirow{2}{*}{121} & \multirow{2}{*}{0.14} \\
\hline After & 10.45 & & \\
\hline \multicolumn{4}{|l|}{ Spring } \\
\hline Before & 6.70 & \multirow{2}{*}{49} & \multirow{2}{*}{0.81} \\
\hline After & 6.83 & & \\
\hline \multicolumn{4}{|l|}{ Summer } \\
\hline Before & 5.60 & \multirow{2}{*}{104} & \multirow{2}{*}{0.56} \\
\hline After & 5.72 & & \\
\hline \multicolumn{4}{|l|}{ Fall } \\
\hline Before & 9.04 & \multirow{2}{*}{37} & \multirow{2}{*}{0.89} \\
\hline After & 8.70 & & \\
\hline
\end{tabular}

* BOLD and shaded indicates significance

\section{Amazon Creek at Royal Avenue}

Table 14: Amazon Creek at Royal Avenue DO Wilcoxon rank-sum test statistics of means, before and after 2008

\begin{tabular}{|c|c|c|c|}
\hline & Geometric Mean & Wilcoxon test statistic, W & p-value \\
\hline \multicolumn{4}{|l|}{ All Data } \\
\hline Before & 8.28 & 1329 & 0.53 \\
\hline
\end{tabular}




\begin{tabular}{|c|c|c|c|}
\hline After & 7.96 & & \\
\hline \multicolumn{4}{|l|}{ Winter } \\
\hline Before & 10.45 & \multirow{2}{*}{157} & \multirow{2}{*}{0.44} \\
\hline After & 10.92 & & \\
\hline \multicolumn{4}{|l|}{ Spring } \\
\hline Before & 7.44 & \multirow{2}{*}{48} & \multirow{2}{*}{0.36} \\
\hline After & 6.59 & & \\
\hline \multicolumn{4}{|l|}{ Summer } \\
\hline Before & 6.51 & \multirow{2}{*}{79} & \multirow{2}{*}{0.09} \\
\hline After & 5.29 & & \\
\hline \multicolumn{4}{|l|}{ Fall } \\
\hline Before & 8.79 & \multirow{2}{*}{39} & \multirow{2}{*}{0.46} \\
\hline After & 8.14 & & \\
\hline
\end{tabular}

* BOLD and shaded indicates significance

\section{Willow Creek at $18^{\text {th }}$ Avenue}

Table 15: Willow Creek at $18^{\text {th }}$ Avenue DO Wilcoxon rank-sum test statistics of means, before and after 2008

\begin{tabular}{|c|c|c|c|}
\hline & Geometric Mean & Wilcoxon test statistic, W & p-value \\
\hline \multicolumn{4}{|l|}{ All Data } \\
\hline Before & 8.76 & \multirow{2}{*}{1334} & \multirow{2}{*}{$<0.01$} \\
\hline After & 10.07 & & \\
\hline \multicolumn{4}{|l|}{ Winter } \\
\hline Before & 10.43 & \multirow{2}{*}{181} & \multirow{2}{*}{0.10} \\
\hline After & 11.15 & & \\
\hline \multicolumn{4}{|l|}{ Spring } \\
\hline Before & 8.71 & \multirow{2}{*}{42} & \multirow{2}{*}{0.34} \\
\hline After & 8.20 & & \\
\hline \multicolumn{4}{|l|}{ Summer } \\
\hline $\begin{array}{r}\text { Before } \\
\text { After }\end{array}$ & \multicolumn{3}{|c|}{$\mathrm{N} / \mathrm{A}$} \\
\hline \multicolumn{4}{|l|}{ Fall } \\
\hline Before & 9.13 & \multirow{2}{*}{56} & \multirow{2}{*}{0.28} \\
\hline After & 10.27 & & \\
\hline
\end{tabular}

* BOLD and shaded indicates significance

\section{Amazon Diversion Channel at Royal Avenue}

Table 16: Amazon Diversion Channel at Royal Avenue DO Wilcoxon rank-sum test statistics of means, before and after 2008

\begin{tabular}{|c|c|c|c|}
\hline & Geometric Mean & Wilcoxon test statistic, W & p-value \\
\hline \multicolumn{4}{|l|}{ All Data } \\
\hline Before & 8.00 & \multirow{2}{*}{1369} & \multirow{2}{*}{0.66} \\
\hline After & 7.88 & & \\
\hline \multicolumn{4}{|l|}{ Winter } \\
\hline Before & 9.78 & \multirow{2}{*}{162} & \multirow{2}{*}{0.35} \\
\hline After & 10.40 & & \\
\hline \multicolumn{4}{|l|}{ Spring } \\
\hline Before & 7.94 & \multirow{2}{*}{42} & \multirow{2}{*}{0.19} \\
\hline After & 6.66 & & \\
\hline \multicolumn{4}{|l|}{ Summer } \\
\hline Before & 6.33 & \multirow{2}{*}{131} & \multirow{2}{*}{0.86} \\
\hline After & 5.96 & & \\
\hline \multicolumn{4}{|l|}{ Fall } \\
\hline Before & 7.92 & \multirow{2}{*}{48} & \multirow{2}{*}{0.94} \\
\hline After & 7.87 & & \\
\hline
\end{tabular}

* BOLD and shaded indicates significance 


\section{A-3 Drain at Terry Street}

Table 17: A-3 Drain at Terry Street DO Wilcoxon rank-sum test statistics of means, before and after 2008

\begin{tabular}{|c|c|c|c|}
\hline & Geometric Mean & Wilcoxon test statistic, W & p-value \\
\hline \multicolumn{4}{|l|}{ All Data } \\
\hline Before & 8.08 & \multirow{2}{*}{861} & \multirow{2}{*}{0.73} \\
\hline After & 7.69 & & \\
\hline \multicolumn{4}{|l|}{ Winter } \\
\hline Before & 9.98 & \multirow{2}{*}{95} & \multirow{2}{*}{0.83} \\
\hline After & 9.70 & & \\
\hline \multicolumn{4}{|l|}{ Spring } \\
\hline Before & 8.40 & \multirow{2}{*}{37} & \multirow{2}{*}{0.80} \\
\hline After & 8.09 & & \\
\hline \multicolumn{4}{|l|}{ Summer } \\
\hline Before & 7.46 & \multirow{2}{*}{25} & \multirow{2}{*}{0.03} \\
\hline After & 4.61 & & \\
\hline \multicolumn{4}{|l|}{ Fall } \\
\hline Before & 6.21 & \multirow{2}{*}{42} & \multirow{2}{*}{0.56} \\
\hline After & 6.90 & & \\
\hline
\end{tabular}

${ }^{*}$ BOLD and shaded indicates significance

\section{Lower Amazon}

\section{Amazon Creek at RM 5.82}

Table 18: Amazon Creek at RM 5.82 DO Wilcoxon rank-sum test statistics of means, before and after 2008

\begin{tabular}{|c|c|c|c|}
\hline & Geometric Mean & Wilcoxon test statistic, W & $p$-value \\
\hline \multicolumn{4}{|l|}{ All Data } \\
\hline $\begin{array}{r}\text { Before } \\
\text { After }\end{array}$ & & $\mathrm{N} / \mathrm{A}$ & \\
\hline \multicolumn{4}{|l|}{ Winter } \\
\hline $\begin{array}{r}\text { Before } \\
\text { After }\end{array}$ & & $\mathrm{N} / \mathrm{A}$ & \\
\hline \multicolumn{4}{|l|}{ Spring } \\
\hline $\begin{array}{r}\text { Before } \\
\text { After }\end{array}$ & & $\mathrm{N} / \mathrm{A}$ & \\
\hline \multicolumn{4}{|l|}{ Summer } \\
\hline $\begin{array}{r}\text { Before } \\
\text { After }\end{array}$ & & $\mathrm{N} / \mathrm{A}$ & \\
\hline \multicolumn{4}{|l|}{ Fall } \\
\hline $\begin{array}{r}\text { Before } \\
\text { After }\end{array}$ & & $\mathrm{N} / \mathrm{A}$ & \\
\hline
\end{tabular}

* BOLD and shaded indicates significance

\section{Amazon Creek at High Pass Road}

Table 19: Amazon Creek at High Pass Road DO Wilcoxon rank-sum test statistics of means, before and after 2008

\begin{tabular}{|c|c|c|c|}
\hline & Geometric Mean & Wilcoxon test statistic, W & p-value \\
\hline \multicolumn{4}{|l|}{ All Data } \\
\hline $\begin{array}{r}\text { Before } \\
\text { After }\end{array}$ & \multicolumn{3}{|c|}{$\mathrm{N} / \mathrm{A}$} \\
\hline \multicolumn{4}{|l|}{ Winter } \\
\hline Before & 10.10 & \multirow{2}{*}{8} & \multirow{2}{*}{0.63} \\
\hline After & 10.82 & & \\
\hline \multicolumn{4}{|l|}{ Spring } \\
\hline Before & 9.40 & 5 & 0.25 \\
\hline
\end{tabular}




\begin{tabular}{|c|c|c|c|}
\hline After & 8.67 & & \\
\hline \multicolumn{4}{|l|}{ Summer } \\
\hline Before & 8.60 & \multirow{2}{*}{12} & \multirow{2}{*}{0.82} \\
\hline After & 8.90 & & \\
\hline \multicolumn{4}{|l|}{ Fall } \\
\hline $\begin{array}{r}\text { Before } \\
\text { After }\end{array}$ & \multicolumn{3}{|c|}{$\mathrm{N} / \mathrm{A}$} \\
\hline
\end{tabular}

${ }^{*}$ BOLD and shaded indicates significance

\section{Coyote Creek}

\section{Coyote Creek at Hamm Road}

Table 20: Coyote Creek at Hamm Road DO Wilcox on rank-sum test statistics of means, before and after 2008

\begin{tabular}{|c|c|c|c|}
\hline & Geometric Mean & Wilcoxon test statistic, W & p-value \\
\hline \multicolumn{4}{|l|}{ All Data } \\
\hline $\begin{array}{r}\text { Before } \\
\text { After }\end{array}$ & \multicolumn{3}{|c|}{$\mathrm{N} / \mathrm{A}$} \\
\hline \multicolumn{4}{|l|}{ Winter } \\
\hline $\begin{array}{r}\text { Before } \\
\text { After }\end{array}$ & \multicolumn{3}{|c|}{$\mathrm{N} / \mathrm{A}$} \\
\hline \multicolumn{4}{|l|}{ Spring } \\
\hline $\begin{array}{r}\text { Before } \\
\text { After }\end{array}$ & \multicolumn{3}{|c|}{$\mathrm{N} / \mathrm{A}$} \\
\hline \multicolumn{4}{|l|}{ Summer } \\
\hline Before & 8.38 & \multirow{2}{*}{2.5} & \multirow{2}{*}{0.08} \\
\hline After & 7.15 & & \\
\hline \multicolumn{4}{|l|}{ Fall } \\
\hline $\begin{array}{r}\text { Before } \\
\text { After }\end{array}$ & & $\mathrm{N} / \mathrm{A}$ & \\
\hline
\end{tabular}

${ }^{*}$ BOLD and shaded indicates significance

\section{Coyote Creek at Powell Road}

Table 21: Coyote Creek at Powell Road DO Wilcoxon rank-sum test statistics of means, before and after 2008

\begin{tabular}{|c|c|c|c|}
\hline & Geometric Mean & Wilcoxon test statistic, W & $p$-value \\
\hline \multicolumn{4}{|l|}{ All Data } \\
\hline $\begin{array}{r}\text { Before } \\
\text { After }\end{array}$ & \multicolumn{3}{|c|}{$\mathrm{N} / \mathrm{A}$} \\
\hline \multicolumn{4}{|l|}{ Winter } \\
\hline $\begin{array}{r}\text { Before } \\
\text { After }\end{array}$ & \multicolumn{3}{|c|}{$\mathrm{N} / \mathrm{A}$} \\
\hline \multicolumn{4}{|l|}{ Spring } \\
\hline $\begin{array}{r}\text { Before } \\
\text { After }\end{array}$ & \multicolumn{3}{|c|}{$\mathrm{N} / \mathrm{A}$} \\
\hline \multicolumn{4}{|l|}{ Summer } \\
\hline Before & 7.36 & \multirow{2}{*}{23} & \multirow{2}{*}{0.73} \\
\hline After & 7.13 & & \\
\hline \multicolumn{4}{|l|}{ Fall } \\
\hline $\begin{array}{r}\text { Before } \\
\text { After }\end{array}$ & & $\mathrm{N} / \mathrm{A}$ & \\
\hline
\end{tabular}

${ }^{*}$ BOLD and shaded indicates significance

\section{Coyote Creek at Petzold Road}

Table 21: Coyote Creek at Petzold road DO Wilcoxon rank-sum test statistics of means, before and after 2008

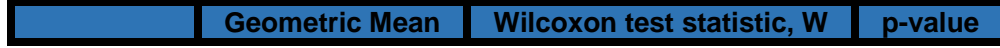




\begin{tabular}{|c|c|c|c|}
\hline All Data & & & \\
\hline $\begin{array}{r}\text { Before } \\
\text { After }\end{array}$ & \multicolumn{3}{|c|}{$\mathrm{N} / \mathrm{A}$} \\
\hline \multicolumn{4}{|l|}{ Winter } \\
\hline $\begin{array}{r}\text { Before } \\
\text { After }\end{array}$ & \multicolumn{3}{|c|}{$\mathrm{N} / \mathrm{A}$} \\
\hline \multicolumn{4}{|l|}{ Spring } \\
\hline $\begin{array}{r}\text { Before } \\
\text { After }\end{array}$ & \multicolumn{3}{|c|}{$\mathrm{N} / \mathrm{A}$} \\
\hline \multicolumn{4}{|l|}{ Summer } \\
\hline Before & 5.84 & \multirow{2}{*}{4} & \multirow{2}{*}{0.05} \\
\hline After & 4.10 & & \\
\hline \multicolumn{4}{|l|}{ Fall } \\
\hline $\begin{array}{r}\text { Before } \\
\text { After }\end{array}$ & & $\mathrm{N} / \mathrm{A}$ & \\
\hline
\end{tabular}

* BOLD and shaded indicates significance 


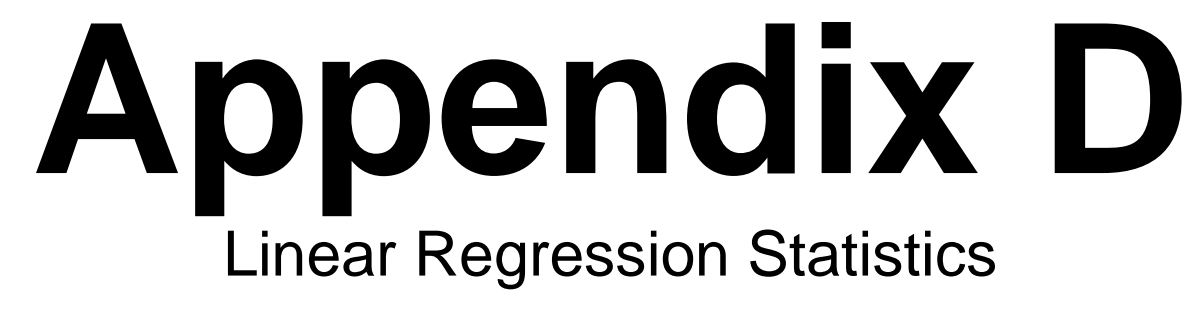




\section{Bacteria (E. coli)}

\section{Upper Amazon}

Table 1: Summary of linear regression analysis of E. coli over time on Amazon Creek at $29^{\text {th }}$ Avenue.

\begin{tabular}{|c|c|c|c|c|c|c|c|}
\hline & & $N$ & Residual Std. Error & Adjusted $\mathrm{R}^{2}$ & Slope* & Trend p-value & Significant $\Delta$ Slope \\
\hline \multirow{3}{*}{ All Data } & Overall & 110 & 0.43 & -0.01 & 1.86 & 0.44 & \multirow{3}{*}{$\begin{array}{c}\mathrm{NO} \\
p=0.42\end{array}$} \\
\hline & Before & 65 & 0.45 & -0.01 & -1.99 & 0.72 & \\
\hline & After & 45 & 0.39 & 0.02 & 12.23 & 0.16 & \\
\hline \multirow{3}{*}{ Winter } & Overall & 33 & 0.47 & -0.03 & 0.51 & 0.91 & \multirow{3}{*}{$\begin{array}{c}\mathrm{NO} \\
p=0.75\end{array}$} \\
\hline & Before & 18 & 0.49 & -0.05 & 12.39 & 0.74 & \\
\hline & After & 15 & 0.49 & -0.08 & 1.78 & 0.92 & \\
\hline \multirow{3}{*}{ Spring } & Overall & 23 & 0.42 & -0.03 & -3.48 & 0.52 & \\
\hline & Before & 14 & 0.40 & 0.13 & -16.18 & 0.09 & \multirow{2}{*}{$\begin{array}{c}\text { No } \\
p=0.19\end{array}$} \\
\hline & After & 9 & 0.39 & -0.03 & 15.71 & 0.40 & \\
\hline \multirow{3}{*}{ Summer } & Overall & 33 & 0.36 & 0.07 & 6.91 & 0.07 & \multirow{3}{*}{$\begin{array}{c}\text { NO } \\
p=0.37\end{array}$} \\
\hline & Before & 19 & 0.38 & 0.09 & 16.05 & 0.11 & \\
\hline & After & 14 & 0.32 & 0.06 & 18.16 & 0.21 & \\
\hline \multirow{3}{*}{ Fall } & Overall & 21 & 0.43 & -0.05 & 1.61 & 0.80 & \multirow{3}{*}{$\begin{array}{c}\text { NO } \\
p=0.52\end{array}$} \\
\hline & Before & 14 & 0.49 & -0.06 & -6.52 & 0.61 & \\
\hline & After & 7 & 0.28 & 0.15 & 24.57 & 0.21 & \\
\hline
\end{tabular}

*Slope is E-10

** Bold and shaded indicate significance was found

\section{Amazon Creek at Railroad Crossing}

Table 2: Summary of linear regression analysis of E. coli over time on Amazon Creek at Railroad Crossing.

\begin{tabular}{|c|c|c|c|c|c|c|c|}
\hline & & $\mathbf{N}$ & Residual Std. Error & Adjusted $\mathrm{R}^{2}$ & Slope* & Trend p-value & Significant $\Delta$ Slope \\
\hline \multirow{3}{*}{ All Data } & Overall & 91 & 0.57 & -0.01 & 2.73 & 0.53 & \multirow{3}{*}{$\begin{array}{c}\mathrm{NO} \\
p=0.90\end{array}$} \\
\hline & Before & 46 & 0.55 & -0.02 & 4.63 & 0.68 & \\
\hline & After & 45 & 0.60 & 0.01 & 13.7 & 0.30 & \\
\hline \multirow{3}{*}{ Winter } & Overall & 27 & 0.53 & -0.03 & 2.48 & 0.72 & \\
\hline & Before & 12 & 0.52 & -0.08 & -8.87 & 0.71 & \multirow{2}{*}{$\begin{array}{c}N O \\
p=0.81\end{array}$} \\
\hline & After & 15 & 0.56 & -0.04 & 13.6 & 0.51 & \\
\hline \multirow{3}{*}{ Spring } & Overall & 19 & 0.62 & -0.01 & -10.4 & 0.34 & \multirow{3}{*}{$\begin{array}{c}\mathrm{NO} \\
p=0.28\end{array}$} \\
\hline & Before & 10 & 0.63 & -0.12 & 5.29 & 0.85 & \\
\hline & After & 9 & 0.68 & -0.13 & -9.50 & 0.77 & \\
\hline \multirow{3}{*}{ Summer } & Overall & 27 & 0.60 & -0.03 & 4.11 & 0.61 & \multirow{3}{*}{$\begin{array}{c}\mathrm{NO} \\
p=0.85\end{array}$} \\
\hline & Before & 13 & 0.44 & 0.03 & -21.1 & 0.27 & \\
\hline & After & 14 & 0.68 & 0.09 & 43.3 & 0.16 & \\
\hline \multirow{3}{*}{ Fall } & Overall & 18 & 0.52 & 0.11 & 17.3 & 0.10 & \\
\hline & Before & 11 & 0.62 & 0.02 & 28.3 & 0.30 & \multirow{2}{*}{$\begin{array}{c}\mathrm{NO} \\
p=0.16\end{array}$} \\
\hline & After & 7 & 0.30 & -0.09 & -13.1 & 0.51 & \\
\hline
\end{tabular}

*Slope is $\mathrm{E}-10$

${ }^{* *}$ Bold and shaded indicates significance was found

\section{Amazon Creek at Royal Avenue}

Table 3: Summary of linear regression analysis of E. coli over time on Amazon Creek at Royal Avenue.

\begin{tabular}{|r|r|c|c|c|c|c|c|}
\hline & & $\mathbf{N}$ & Residual Std. Error & Adjusted $\mathbf{R}^{2}$ & Slope $^{*}$ & Trend p-value & Significant $\Delta$ Slope \\
\cline { 2 - 9 } All Data & Overall & 109 & 0.70 & 0.01 & -4.49 & 0.26 & \\
\cline { 2 - 8 } & Before & 65 & 0.70 & 0.02 & -12.7 & 0.14 & NO \\
& After & 44 & 0.71 & -0.02 & 4.91 & 0.76 & $\mathrm{p}=0.50$ \\
\hline
\end{tabular}




\begin{tabular}{|c|c|c|c|c|c|c|c|}
\hline \multirow{3}{*}{ Winter } & Overall & 33 & 0.69 & -0.01 & 5.71 & 0.40 & \multirow{3}{*}{$\begin{array}{c}\mathrm{NO} \\
p=0.70\end{array}$} \\
\hline & Before & 18 & 0.64 & -0.05 & -7.17 & 0.66 & \\
\hline & After & 15 & 0.79 & -0.08 & -0.05 & 0.99 & \\
\hline \multirow{3}{*}{ Spring } & Overall & 23 & 0.75 & 0.01 & -10.4 & 0.28 & \\
\hline & Before & 14 & 0.77 & 0.01 & -21.5 & 0.30 & \multirow{2}{*}{$\begin{array}{c}\mathrm{NO} \\
\mathrm{p}=0.65\end{array}$} \\
\hline & After & 9 & 0.76 & -0.11 & 15.9 & 0.66 & \\
\hline \multirow{3}{*}{ Summer } & Overall & 32 & 0.61 & 0.05 & -10.4 & 0.11 & \multirow{3}{*}{$\begin{array}{c}\mathrm{NO} \\
p=0.46\end{array}$} \\
\hline & Before & 19 & 0.47 & -0.05 & -3.16 & 0.79 & \\
\hline & After & 13 & 0.78 & -0.06 & 17.7 & 0.61 & \\
\hline \multirow{3}{*}{ Fall } & Overall & 21 & 0.74 & -0.03 & -7.23 & 0.51 & \\
\hline & Before & 14 & 0.81 & 0.07 & -28.1 & 0.19 & \multirow{2}{*}{$\begin{array}{c}\mathrm{NO} \\
p=0.30\end{array}$} \\
\hline & After & 7 & 0.50 & -0.01 & -29.8 & 0.37 & \\
\hline
\end{tabular}

*Slope is E-10

${ }^{* *}$ Bold and shaded indicates significance was found

\section{Willow Creek at $18^{\text {th }}$ Avenue}

Table 4: Summary of linear regression analysis of E. coli over time on Willow Creek at 18th Avenue.

\begin{tabular}{|c|c|c|c|c|c|c|c|}
\hline & & $\mathbf{N}$ & Residual Std. Error & Adjusted $\mathrm{R}^{2}$ & Slope* & Trend $\mathrm{p}$-value & Significant $\Delta$ Slope \\
\hline \multirow{3}{*}{ All Data } & Overall & 95 & 0.67 & -0.01 & 0.83 & 0.84 & \multirow{3}{*}{$\begin{array}{c}\mathrm{NO} \\
p=0.13\end{array}$} \\
\hline & Before & 64 & 0.67 & 0.03 & -13.4 & 0.11 & \\
\hline & After & 31 & 0.65 & -0.03 & 2.02 & 0.91 & \\
\hline \multirow{3}{*}{ Winter } & Overall & 33 & 0.52 & -0.02 & 3.40 & 0.51 & \multirow{3}{*}{$\begin{array}{c}\mathrm{NO} \\
p=0.70\end{array}$} \\
\hline & Before & 18 & 0.36 & 0.01 & -9.09 & 0.30 & \\
\hline & After & 15 & 0.67 & -0.06 & 11.7 & 0.64 & \\
\hline \multirow{3}{*}{ Spring } & Overall & 22 & 0.51 & 0.13 & -13.9 & 0.06 & \multirow{3}{*}{$\begin{array}{c}N O \\
p=0.26\end{array}$} \\
\hline & Before & 14 & 0.46 & 0.33 & -32.2 & 0.02 & \\
\hline & After & 8 & 0.58 & -0.17 & 1.16 & 0.97 & \\
\hline \multirow{3}{*}{ Summer } & Overall & 20 & 0.79 & 0.03 & 17.4 & 0.22 & \multirow{3}{*}{$\mathrm{N} / \mathrm{A}$} \\
\hline & Before & 18 & 0.76 & -0.05 & -10.3 & 0.63 & \\
\hline & After & 2 & \multicolumn{4}{|c|}{$\mathrm{N} / \mathrm{A}$} & \\
\hline \multirow{3}{*}{ Fall } & Overall & 20 & 0.73 & -0.02 & -8.74 & 0.42 & \\
\hline & Before & 14 & 0.73 & 0.13 & -31.3 & 0.11 & \multirow{2}{*}{$\begin{array}{c}\mathrm{NO} \\
p=0.23\end{array}$} \\
\hline & After & 6 & 0.63 & -0.04 & -42.6 & 0.43 & \\
\hline
\end{tabular}

${ }^{*}$ Slope is $\mathrm{E}-10$

${ }^{* *}$ Bold and shaded indicates significance was found

\section{Amazon Diversion Channel at Royal Avenue}

Table 5: Summary of linear regression analysis of E. coli over time on Amazon Diversion Channel at Royal Avenue.

\begin{tabular}{|c|c|c|c|c|c|c|c|}
\hline & & $\mathbf{N}$ & Residual Std. Error & Adjusted $\mathbf{R}^{2}$ & Slope* & Trend p-value & Significant $\Delta$ Slope \\
\hline \multirow{3}{*}{ All Data } & Overall & 109 & 0.89 & -0.01 & -4.05 & 0.42 & \multirow{3}{*}{$\begin{array}{c}\mathrm{NO} \\
p=0.12\end{array}$} \\
\hline & Before & 64 & 0.92 & 0.01 & -14.6 & 0.20 & \\
\hline & After & 45 & 0.82 & 0.05 & 31.6 & 0.08 & \\
\hline \multirow{3}{*}{ Winter } & Overall & 33 & 1.01 & -0.03 & 3.63 & 0.71 & \multirow{3}{*}{$\begin{array}{c}\mathrm{NO} \\
p=0.21\end{array}$} \\
\hline & Before & 18 & 1.00 & -0.01 & -21.1 & 0.37 & \\
\hline & After & 15 & 0.99 & 0.10 & 56.8 & 0.14 & \\
\hline \multirow{3}{*}{ Spring } & Overall & 22 & 0.60 & -0.04 & -2.63 & 0.73 & \multirow{3}{*}{$\begin{array}{c}\mathrm{NO} \\
p=0.76\end{array}$} \\
\hline & Before & 13 & 0.72 & -0.06 & -11.2 & 0.59 & \\
\hline & After & 9 & 0.42 & -0.07 & 13.1 & 0.52 & \\
\hline \multirow{3}{*}{ Summer } & Overall & 30 & 0.71 & 0.09 & -15.0 & 0.05 & \multirow{3}{*}{$\begin{array}{c}\text { YES } \\
p=0.05\end{array}$} \\
\hline & Before & 19 & 0.54 & -0.04 & -6.35 & 0.64 & \\
\hline & After & 11 & 0.82 & 0.07 & 48.4 & 0.18 & \\
\hline \multirow{3}{*}{ Fall } & Overall & 17 & 0.80 & -0.05 & 0.68 & 0.95 & \multirow{3}{*}{$\begin{array}{c}\mathrm{NO} \\
p=0.47\end{array}$} \\
\hline & Before & 10 & 0.89 & -0.06 & -11.6 & 0.61 & \\
\hline & After & 7 & 0.58 & 0.05 & -40.7 & 0.30 & \\
\hline
\end{tabular}


*Slope is $\mathrm{E}-10$

** Bold and shaded indicates significance was found

\section{A-3 Drain at Terry Street}

Table 6: Summary of linear regression analysis of E. coli over time on A-3 Drain at Terry Street.

\begin{tabular}{|c|c|c|c|c|c|c|c|}
\hline & & $\mathbf{N}$ & Residual Std. Error & Adjusted $\mathbf{R}^{2}$ & Slope* & Trend p-value & Significant $\Delta$ Slope \\
\hline \multirow{3}{*}{ All Data } & Overall & 83 & 0.70 & -0.01 & -4.53 & 0.41 & \multirow{3}{*}{$\begin{array}{c}\mathrm{NO} \\
p=0.87\end{array}$} \\
\hline & Before & 43 & 0.73 & 0.02 & 19.6 & 0.19 & \\
\hline & After & 40 & 0.66 & -0.02 & -8.29 & 0.59 & \\
\hline \multirow{3}{*}{ Winter } & Overall & 27 & 0.64 & -0.03 & -3.36 & 0.69 & \multirow{3}{*}{$\begin{array}{c}\mathrm{NO} \\
p=0.75\end{array}$} \\
\hline & Before & 12 & 0.63 & -0.05 & 18.6 & 0.52 & \\
\hline & After & 15 & 0.69 & -0.07 & -4.21 & 0.87 & \\
\hline \multirow{3}{*}{ Spring } & Overall & 18 & 0.54 & 0.05 & -12.3 & 0.19 & \multirow{3}{*}{$\begin{array}{c}\mathrm{NO} \\
p=0.75\end{array}$} \\
\hline & Before & 9 & 0.66 & -0.14 & 7.02 & 0.83 & \\
\hline & After & 9 & 0.44 & -0.07 & -14.0 & 0.51 & \\
\hline \multirow{3}{*}{ Summer } & Overall & 21 & 0.56 & -0.01 & 7.32 & 0.41 & \multirow{3}{*}{$\begin{array}{c}N O \\
p=0.18\end{array}$} \\
\hline & Before & 12 & 0.62 & 0.15 & 44.8 & 0.11 & \\
\hline & After & 9 & 0.36 & -0.03 & 17.6 & 0.40 & \\
\hline \multirow{3}{*}{ Fall } & Overall & 17 & 0.50 & -0.06 & 3.43 & 0.73 & \multirow{3}{*}{$\begin{array}{c}\mathrm{NO} \\
p=0.95\end{array}$} \\
\hline & Before & 10 & 0.61 & -0.12 & 3.03 & 0.91 & \\
\hline & After & 7 & 0.38 & -0.18 & -6.00 & 0.80 & \\
\hline
\end{tabular}

${ }^{*}$ Slope is E-10

** Bold and shaded indicates significance was found

\section{Lower Amazon}

Table 7: Summary of linear regression analysis of E. coli over time on Amazon Creek at RM 5.82.

\begin{tabular}{|c|c|c|c|c|c|c|c|}
\hline & & $\mathbf{N}$ & Residual Std. Error & Adjusted $\mathbf{R}^{2}$ & Slope* & Trend p-value & Significant $\Delta$ Slope \\
\hline \multirow{3}{*}{ All Data } & Overall & 5 & 0.18 & 0.68 & -1950 & 0.11 & \multirow{3}{*}{$\mathrm{N} / \mathrm{A}$} \\
\hline & Before & 0 & \multicolumn{4}{|c|}{$\mathrm{N} / \mathrm{A}$} & \\
\hline & After & 5 & 0.18 & 0.68 & -1950 & 0.11 & \\
\hline \multirow{3}{*}{ Winter } & Overall & 0 & \multirow{3}{*}{\multicolumn{4}{|c|}{$\mathrm{N} / \mathrm{A}$}} & \multirow{3}{*}{$\mathrm{N} / \mathrm{A}$} \\
\hline & Before & 0 & & & & & \\
\hline & After & 0 & & & & & \\
\hline \multirow{3}{*}{ Spring } & Overall & 0 & \multirow{3}{*}{\multicolumn{4}{|c|}{$\mathrm{N} / \mathrm{A}$}} & \multirow{3}{*}{$\mathrm{N} / \mathrm{A}$} \\
\hline & Before & 0 & & & & & \\
\hline & After & 0 & & & & & \\
\hline \multirow{3}{*}{ Summer } & Overall & 5 & 0.18 & 0.68 & -1950 & 0.11 & \multirow{3}{*}{$\mathrm{N} / \mathrm{A}$} \\
\hline & Before & 0 & & $\mathrm{~N} / \mathrm{A}$ & & & \\
\hline & After & 5 & 0.18 & 0.68 & -1950 & 0.11 & \\
\hline \multirow{3}{*}{ Fall } & Overall & 0 & & $\mathrm{~N} / \mathrm{A}$ & & & \\
\hline & Before & 0 & & & & & \multirow{2}{*}{$\mathrm{N} / \mathrm{A}$} \\
\hline & After & 0 & & & & & \\
\hline
\end{tabular}

*Slope is E-10

** Bold and shaded significance was found

\section{Amazon Creek at High Pass Road}

Table 8: Summary of linear regression analysis of E. coli over time on Amazon Creek at High Pass Road.

\begin{tabular}{|r|r|c|c|c|c|c|c|}
\hline & & $\mathbf{N}$ & Residual Std. Error & Adjusted $\mathbf{R}^{2}$ & Slope $^{*}$ & Trend $\mathbf{p}$-value & Significant $\Delta$ Slope \\
\cline { 2 - 9 } All Data & Overall & 64 & 0.66 & -0.01 & 3.99 & 0.35 & \\
\cline { 2 - 9 } & Before & 42 & $\mathbf{0 . 5 9}$ & $\mathbf{0 . 1 1}$ & $\mathbf{8 0 . 2}$ & $\mathbf{0 . 0 1}$ & YES \\
\cline { 2 - 8 } & After & 22 & 0.85 & -0.05 & 16.0 & 0.70 & $\mathbf{0 . 0 4}$ \\
\hline
\end{tabular}




\begin{tabular}{|c|c|c|c|c|c|c|c|}
\hline \multirow{3}{*}{ Winter } & Overall & 15 & 0.91 & -0.09 & -2.65 & 0.87 & \multirow{3}{*}{$\begin{array}{c}\mathrm{NO} \\
p=0.20\end{array}$} \\
\hline & Before & 10 & 0.85 & 0.08 & 130 & 0.22 & \\
\hline & After & 5 & 0.82 & 0.34 & 270 & 0.39 & \\
\hline \multirow{3}{*}{ Spring } & Overall & 19 & 0.52 & 0.01 & 7.43 & 0.32 & \multirow{3}{*}{$\begin{array}{c}\mathrm{NO} \\
p=0.40\end{array}$} \\
\hline & Before & 15 & 0.54 & 0.05 & 52.5 & 0.21 & \\
\hline & After & 4 & 0.29 & 0.12 & -107 & 0.36 & \\
\hline \multirow{3}{*}{ Summer } & Overall & 20 & 0.40 & 0.05 & 6.30 & 0.18 & \multirow{3}{*}{$\begin{array}{c}\text { YES } \\
p=0.07\end{array}$} \\
\hline & Before & 14 & 0.36 & 0.26 & 82.4 & 0.04 & \\
\hline & After & 6 & 0.34 & 0.02 & -58.2 & 0.36 & \\
\hline \multirow{3}{*}{ Fall } & Overall & 17 & 0.83 & -0.05 & 2.35 & 0.82 & \multirow{3}{*}{$\begin{array}{c}\mathrm{NO} \\
p=0.42\end{array}$} \\
\hline & Before & 10 & 0.70 & 0.42 & 313 & 0.02 & \\
\hline & After & 7 & 0.72 & -0.07 & 10.9 & 0.52 & \\
\hline
\end{tabular}

*Slope is $\mathrm{E}-10$

${ }^{* *}$ Bold and shaded significance was found

\section{Coyote Creek}

\section{Coyote Creek at Hamm Road}

Table 9: Summary of linear regression analysis of E. coli over time on Coyote Creek at Hamm Road.

\begin{tabular}{|c|c|c|c|c|c|c|c|}
\hline & & $\mathbf{N}$ & Residual Std. Error & Adjusted $\mathbf{R}^{2}$ & Slope* & Trend p-value & Significant $\Delta$ Slope \\
\hline \multirow{3}{*}{ All Data } & Overall & 32 & 0.87 & 0.11 & 22.5 & 0.03 & \multirow{3}{*}{$\mathrm{N} / \mathrm{A}$} \\
\hline & Before & 28 & 0.88 & 0.10 & 245 & 0.05 & \\
\hline & After & 4 & 0.12 & -0.41 & -164 & 0.76 & \\
\hline \multirow{3}{*}{ Winter } & Overall & 3 & 0.38 & -0.90 & -699 & 0.86 & \\
\hline & Before & 3 & 0.38 & -0.90 & -699 & 0.86 & \multirow{2}{*}{$\mathrm{N} / \mathrm{A}$} \\
\hline & After & 0 & \multicolumn{4}{|c|}{$\mathrm{N} / \mathrm{A}$} & \\
\hline \multirow{3}{*}{ Spring } & Overall & 10 & 0.32 & -0.10 & -28.4 & 0.68 & \multirow{3}{*}{$\mathrm{N} / \mathrm{A}$} \\
\hline & Before & 10 & 0.32 & -0.10 & -28.4 & 0.68 & \\
\hline & After & 0 & & $\mathrm{~N} / \mathrm{A}$ & & & \\
\hline \multirow{3}{*}{ Summer } & Overall & 15 & 0.44 & -0.07 & -0.94 & 0.87 & \multirow{3}{*}{$\begin{array}{c}\mathrm{NO} \\
p=0.45\end{array}$} \\
\hline & Before & 11 & 0.49 & 0.04 & 118 & 0.27 & \\
\hline & After & 4 & 0.12 & -0.41 & -164 & 0.76 & \\
\hline \multirow{3}{*}{ Fall } & Overall & 4 & 0.36 & 0.45 & -2430 & 0.13 & \multirow{3}{*}{$\mathrm{N} / \mathrm{A}$} \\
\hline & Before & 4 & 0.36 & 0.45 & -2430 & 0.13 & \\
\hline & After & 0 & \multicolumn{4}{|c|}{$N / A$} & \\
\hline
\end{tabular}

*Slope is E-10

** Bold and increased font size indicates significance was found

\section{Coyote Creek at Powell Road}

Table 10: Summary of linear regression analysis of E. coli over time on Coyote Creek at Powell Road.

\begin{tabular}{|c|c|c|c|c|c|c|c|}
\hline & & $\mathbf{N}$ & Residual Std. Error & Adjusted $\mathrm{R}^{2}$ & Slope* & Trend p-value & Significant $\Delta$ Slope \\
\hline \multirow{3}{*}{ All Data } & Overall & 63 & 0.44 & -0.01 & -3.21 & 0.53 & \multirow{3}{*}{$\mathrm{N} / \mathrm{A}$} \\
\hline & Before & 59 & 0.45 & -0.01 & -19.3 & 0.36 & \\
\hline & After & 4 & 0.41 & -0.19 & -1180 & 0.55 & \\
\hline \multirow{3}{*}{ Winter } & Overall & 10 & 0.26 & -0.12 & -3.63 & 0.91 & \multirow{3}{*}{$\mathrm{N} / \mathrm{A}$} \\
\hline & Before & 10 & 0.26 & -0.12 & -3.63 & 0.91 & \\
\hline & After & 0 & \multicolumn{4}{|c|}{$\mathrm{N} / \mathrm{A}$} & \\
\hline \multirow{3}{*}{ Spring } & Overall & 17 & 0.37 & 0.21 & -59.5 & 0.04 & \multirow{3}{*}{$\mathrm{N} / \mathrm{A}$} \\
\hline & Before & 17 & 0.37 & 0.21 & -59.5 & 0.04 & \\
\hline & After & 0 & \multicolumn{4}{|c|}{$\mathrm{N} / \mathrm{A}$} & \\
\hline \multirow{3}{*}{ Summer } & Overall & 23 & 0.44 & -0.05 & 1.23 & 0.82 & \multirow{3}{*}{$\begin{array}{c}\mathrm{NO} \\
p=0.42\end{array}$} \\
\hline & Before & 19 & 0.44 & 0.02 & 49.4 & 0.56 & \\
\hline & After & 4 & 0.41 & -0.19 & -1180 & 0.55 & \\
\hline Fall & Overall & 11 & 0.53 & -0.09 & -1.27 & 0.98 & \\
\hline
\end{tabular}




\begin{tabular}{|c|c|c|c|c|c|c|c|}
\hline & Before & 11 & 0.53 & -0.09 & -1.27 & 0.98 & \multirow{2}{*}{$\mathrm{N} / \mathrm{A}$} \\
\hline & After & 0 & \multicolumn{4}{|c|}{ N/A } & \\
\hline
\end{tabular}

** Bold and increased font size indicates significance was found

\section{Coyote Creek at Petzold Road}

Table 11: Summary of linear regression analysis of E. coli over time on Coyote Creek at Petzold Road.

\begin{tabular}{|c|c|c|c|c|c|c|c|}
\hline & & $\mathbf{N}$ & Residual Std. Error & Adjusted $\mathrm{R}^{2}$ & Slope* & Trend p-value & Significant $\Delta$ Slope \\
\hline \multirow{3}{*}{ All Data } & Overall & 58 & 0.51 & -0.02 & -1.16 & 0.86 & \multirow{3}{*}{$\mathrm{N} / \mathrm{A}$} \\
\hline & Before & 55 & 0.50 & -0.02 & 7.37 & 0.75 & \\
\hline & After & 3 & 0.75 & -0.42 & 3140 & 0.64 & \\
\hline \multirow{3}{*}{ Winter } & Overall & 10 & 0.52 & -0.09 & 31.6 & 0.61 & \multirow{3}{*}{$\mathrm{N} / \mathrm{A}$} \\
\hline & Before & 10 & 0.52 & -0.09 & 31.6 & 0.61 & \\
\hline & After & 0 & \multicolumn{4}{|c|}{$\mathrm{N} / \mathrm{A}$} & \\
\hline \multirow{3}{*}{ Spring } & Overall & 17 & 0.44 & 0.06 & -43.5 & 0.17 & \\
\hline & Before & 17 & 0.44 & 0.06 & -43.5 & 0.17 & \multirow{2}{*}{$\mathrm{N} / \mathrm{A}$} \\
\hline & After & 0 & & N/A & & & \\
\hline \multirow{3}{*}{ Summer } & Overall & 18 & 0.38 & 0.01 & 5.29 & 0.33 & \multirow{3}{*}{$\begin{array}{c}\mathrm{NO} \\
p=0.45\end{array}$} \\
\hline & Before & 15 & $0 . .31$ & -0.01 & 30.1 & 0.35 & \\
\hline & After & 3 & 0.75 & -0.42 & 3140 & 0.64 & \\
\hline \multirow{3}{*}{ Fall } & Overall & 13 & 0.62 & -0.01 & 63.2 & 0.38 & \multirow{3}{*}{$\mathrm{N} / \mathrm{A}$} \\
\hline & Before & 13 & 0.62 & -0.01 & 63.2 & 0.38 & \\
\hline & After & 0 & \multicolumn{4}{|c|}{$\mathrm{N} / \mathrm{A}$} & \\
\hline
\end{tabular}

${ }^{*}$ Slope is E-10

${ }^{* *}$ Bold and increased font size indicates significance was found 


\section{Dissolved Oxygen}

\section{Upper Amazon}

\section{Amazon Creek at 29 $^{\text {th }}$ Avenue}

Table 12: Summary of linear regression analysis of DO over time on Amazon Creek at $29^{\text {th }}$ Avenue.

\begin{tabular}{|c|c|c|c|c|c|c|c|}
\hline & & $\mathrm{N}$ & Residual Std. Error & Adjusted $\mathrm{R}^{2}$ & Slope* & Trend p-value & Significant $\Delta$ Slope \\
\hline \multirow{3}{*}{ All Data } & Overall & 110 & 2.41 & 0.01 & 14.1 & 0.30 & \multirow{3}{*}{$\begin{array}{c}\mathrm{NO} \\
p=0.36\end{array}$} \\
\hline & Before & 65 & 2.39 & -0.01 & -22.7 & 0.44 & \\
\hline & After & 45 & 2.43 & -0.01 & 36.7 & 0.49 & \\
\hline \multirow{3}{*}{ Winter } & Overall & 33 & 1.56 & -0.02 & 7.58 & 0.62 & \multirow{3}{*}{$\begin{array}{c}\text { NO } \\
p=0.47\end{array}$} \\
\hline & Before & 18 & 1.05 & 0.01 & -28.7 & 0.29 & \\
\hline & After & 15 & 2.04 & -0.03 & 55.1 & 0.47 & \\
\hline \multirow{3}{*}{ Spring } & Overall & 23 & 1.34 & -0.04 & -5.18 & 0.76 & \multirow{3}{*}{$\begin{array}{c}\text { NO } \\
p=0.62\end{array}$} \\
\hline & Before & 14 & 1.48 & -0.07 & -8.57 & 0.79 & \\
\hline & After & 9 & 1.29 & 0.01 & -61.4 & 0.33 & \\
\hline \multirow{3}{*}{ Summer } & Overall & 33 & 1.47 & 0.06 & 26.8 & 0.08 & \multirow{3}{*}{$\begin{array}{c}\text { YES } \\
p=0.05\end{array}$} \\
\hline & Before & 19 & 1.58 & -0.01 & -37.1 & 0.36 & \\
\hline & After & 14 & 1.00 & 0.38 & 126 & 0.01 & \\
\hline \multirow{3}{*}{ Fall } & Overall & 21 & 1.65 & -0.02 & 17.6 & 0.47 & \multirow{3}{*}{$\begin{array}{c}\mathrm{NO} \\
p=0.24\end{array}$} \\
\hline & Before & 14 & 1.50 & -0.07 & -17.0 & 0.66 & \\
\hline & After & 7 & 1.81 & -0.04 & -96.7 & 0.42 & \\
\hline
\end{tabular}

*Slope is $\mathrm{E}-10$

** Bold and shaded indicate significance was found

\section{Amazon Creek at Railroad Crossing}

Table 13: Summary of linear regression analysis of DO over time on Amazon Creek at Railroad Crossing.

\begin{tabular}{|c|c|c|c|c|c|c|c|}
\hline & & $\mathbf{N}$ & Residual Std. Error & Adjusted $\mathrm{R}^{2}$ & Slope* & Trend p-value & Significant $\Delta$ Slope \\
\hline \multirow{3}{*}{ All Data } & Overall & 91 & 2.65 & -0.01 & 7.27 & 0.72 & \multirow{3}{*}{$\begin{array}{c}\mathrm{NO} \\
p=0.72\end{array}$} \\
\hline & Before & 46 & 2.64 & -0.02 & -29.7 & 0.58 & \\
\hline & After & 45 & 2.70 & -0.02 & 30.0 & 0.61 & \\
\hline \multirow{3}{*}{ Winter } & Overall & 27 & 1.69 & 0.02 & 26.4 & 0.23 & \multirow{3}{*}{$\begin{array}{c}N O \\
p=0.61\end{array}$} \\
\hline & Before & 12 & 1.17 & -0.04 & -40.9 & 0.45 & \\
\hline & After & 15 & 2.05 & -0.03 & 56.8 & 0.46 & \\
\hline \multirow{3}{*}{ Spring } & Overall & 19 & 2.13 & -0.04 & 21.3 & 0.56 & \multirow{3}{*}{$\begin{array}{c}\mathrm{NO} \\
\mathrm{p}=0.77\end{array}$} \\
\hline & Before & 10 & 2.32 & -0.04 & 83.5 & 0.43 & \\
\hline & After & 9 & 2.12 & -0.13 & 31.6 & 0.75 & \\
\hline \multirow{3}{*}{ Summer } & Overall & 27 & 1.55 & -0.04 & 4.40 & 0.83 & \multirow{3}{*}{$\begin{array}{c}\mathrm{NO} \\
p=0.93\end{array}$} \\
\hline & Before & 13 & 1.57 & -0.09 & -13.9 & 0.83 & \\
\hline & After & 14 & 1.65 & -0.08 & 20.8 & 0.77 & \\
\hline \multirow{3}{*}{ Fall } & Overall & 18 & 2.36 & 0.07 & -70.1 & 0.14 & \multirow{3}{*}{$\begin{array}{c}N O \\
p=0.20\end{array}$} \\
\hline & Before & 11 & 2.56 & 0.24 & -215 & 0.07 & \\
\hline & After & 7 & 1.56 & 0.09 & -1.19 & 0.26 & \\
\hline
\end{tabular}

${ }^{*}$ Slope is E-10

** Bold and shaded indicate significance was found

\section{Amazon Creek at Royal Avenue}

Table 14: Summary of linear regression analysis of DO over time on Amazon Creek at Royal Avenue.

\begin{tabular}{|c|c|c|c|c|c|c|c|}
\hline \multirow{3}{*}{ All Data } & & $\mathbf{N}$ & Residual Std. Error & Adjusted R & Slope $^{\star}$ & Trend p-value & Significant $\Delta$ Slope \\
\cline { 2 - 8 } & Overall & 110 & 2.65 & -0.01 & -6.00 & 0.69 & \\
\cline { 2 - 8 } & Before & 64 & 2.50 & -0.01 & 12.1 & 0.69 & NO \\
\hline
\end{tabular}




\begin{tabular}{|c|c|c|c|c|c|c|c|}
\hline & After & 44 & 2.91 & -0.02 & 6.02 & 0.93 & $p=0.78$ \\
\hline \multirow{3}{*}{ Winter } & Overall & 33 & 1.65 & -0.02 & 11.4 & 0.48 & \multirow{3}{*}{$\begin{array}{c}\mathrm{NO} \\
p=0.76\end{array}$} \\
\hline & Before & 18 & 1.93 & -0.06 & -15.8 & 0.75 & \\
\hline & After & 15 & 1.34 & -0.04 & 32.1 & 0.52 & \\
\hline \multirow{3}{*}{ Spring } & Overall & 23 & 2.37 & -0.03 & -19.1 & 0.53 & \multirow{3}{*}{$\begin{array}{c}\mathrm{NO} \\
p=0.32\end{array}$} \\
\hline & Before & 14 & 2.42 & -0.03 & 48.4 & 0.45 & \\
\hline & After & 9 & 2.22 & 0.08 & -131 & 0.24 & \\
\hline \multirow{3}{*}{ Summer } & Overall & 31 & 2.04 & 0.01 & -21.7 & 0.32 & \multirow{3}{*}{$\begin{array}{c}\text { NO } \\
p=0.30\end{array}$} \\
\hline & Before & 18 & 2.25 & -0.03 & 41.1 & 0.47 & \\
\hline & After & 13 & 1.62 & -0.07 & 32.2 & 0.66 & \\
\hline \multirow{3}{*}{ Fall } & Overall & 21 & 1.34 & -0.01 & -18.5 & 0.35 & \multirow{3}{*}{$\begin{array}{c}\mathrm{NO} \\
p=0.85\end{array}$} \\
\hline & Before & 14 & 1.12 & -0.08 & -2.42 & 0.93 & \\
\hline & After & 7 & 1.92 & -0.18 & -32.2 & 0.79 & \\
\hline
\end{tabular}

*Slope is E-10

** Bold and shaded indicate significance was found

\section{Willow Creek at $18^{\text {th }}$ Avenue}

Table 15: Summary of linear regression analysis of DO over time on Willow Creek at 18th Avenue.

\begin{tabular}{|c|c|c|c|c|c|c|c|}
\hline & & $\mathrm{N}$ & Residual Std. Error & Adjusted $\mathrm{R}^{2}$ & Slope* & Trend p-value & Significant $\Delta$ Slope \\
\hline \multirow{3}{*}{ All Data } & Overall & 95 & 2.23 & 0.06 & 3.77 & 0.01 & \multirow{3}{*}{$\begin{array}{c}\mathrm{NO} \\
p=0.54\end{array}$} \\
\hline & Before & 64 & 2.12 & -0.01 & 13.3 & 0.61 & \\
\hline & After & 31 & 2.45 & 0.01 & 80.0 & 0.24 & \\
\hline \multirow{3}{*}{ Winter } & Overall & 33 & 2.23 & -0.02 & 11.6 & 0.59 & \multirow{3}{*}{$\begin{array}{c}\text { YES } \\
p=0.07\end{array}$} \\
\hline & Before & 18 & 1.67 & 0.16 & -79.1 & 0.06 & \\
\hline & After & 15 & 2.50 & 0.04 & 119 & 0.22 & \\
\hline \multirow{3}{*}{ Spring } & Overall & 22 & 1.52 & -0.05 & 4.94 & 0.81 & \\
\hline & Before & 14 & 1.54 & 0.02 & 44.8 & 0.28 & \multirow{2}{*}{$\begin{array}{c}\mathrm{NO} \\
p=0.24\end{array}$} \\
\hline & After & 8 & 1.34 & 0.06 & 89.7 & 0.28 & \\
\hline \multirow{3}{*}{ Summer } & Overall & 20 & 1.49 & 0.17 & 56.1 & 0.04 & \multirow{3}{*}{$\mathrm{N} / \mathrm{A}$} \\
\hline & Before & 18 & 1.57 & 0.03 & 54.1 & 0.23 & \\
\hline & After & 2 & \multicolumn{4}{|c|}{$\mathrm{N} / \mathrm{A}$} & \\
\hline \multirow{3}{*}{ Fall } & Overall & 20 & 1.97 & 0.01 & 29.2 & 0.32 & \multirow{3}{*}{$\begin{array}{c}\mathrm{NO} \\
\mathrm{p}=0.14\end{array}$} \\
\hline & Before & 14 & 1.85 & -0.03 & 35.5 & 0.46 & \\
\hline & After & 6 & 1.85 & 0.33 & -265 & 0.13 & \\
\hline
\end{tabular}

*Slope is E-10

** Bold and shaded indicate significance was found

\section{Amazon Diversion Channel at Royal Avenue}

Table 16: Summary of linear regression analysis of DO over time on Amazon Diversion Channel at Royal Avenue.

\begin{tabular}{|c|c|c|c|c|c|c|c|}
\hline & & $\mathbf{N}$ & Residual Std. Error & Adjusted $\mathrm{R}^{2}$ & Slope* & Trend p-value & Significant $\Delta$ Slope \\
\hline \multirow{3}{*}{ All Data } & Overall & 105 & 2.63 & -0.01 & -8.86 & 0.55 & \multirow{3}{*}{$\begin{array}{c}\mathrm{NO} \\
p=0.66\end{array}$} \\
\hline & Before & 64 & 2.65 & 0.01 & -32.5 & 0.32 & \\
\hline & After & 41 & 2.64 & -0.02 & 17.8 & 0.76 & \\
\hline \multirow{3}{*}{ Winter } & Overall & 33 & 1.78 & 0.01 & 20.0 & 0.25 & \multirow{3}{*}{$\begin{array}{c}\text { NO } \\
p=0.99\end{array}$} \\
\hline & Before & 18 & 1.84 & -0.05 & 17.9 & 0.70 & \\
\hline & After & 15 & 1.83 & -0.06 & 30.5 & 0.65 & \\
\hline \multirow{3}{*}{ Spring } & Overall & 23 & 2.39 & -0.03 & -20.4 & 0.51 & \multirow{3}{*}{$\begin{array}{c}\mathrm{NO} \\
p=0.48\end{array}$} \\
\hline & Before & 14 & 2.28 & -0.06 & 32.9 & 0.59 & \\
\hline & After & 9 & 2.65 & -0.12 & 40.8 & 0.75 & \\
\hline \multirow{3}{*}{ Summer } & Overall & 32 & 2.30 & 0.02 & -30.5 & 0.21 & \multirow{3}{*}{$\begin{array}{c}\mathrm{NO} \\
p=0.18\end{array}$} \\
\hline & Before & 18 & 2.81 & 0.12 & -128 & 0.09 & \\
\hline & After & 14 & 1.10 & -0.08 & 2.71 & 0.95 & \\
\hline \multirow{3}{*}{ Fall } & Overall & 21 & 2.21 & -0.03 & -19.1 & 0.56 & \multirow{3}{*}{$\begin{array}{c}\mathrm{NO} \\
p=0.73\end{array}$} \\
\hline & Before & 14 & 2.28 & -0.05 & -35.3 & 0.55 & \\
\hline & After & 7 & 2.33 & -0.08 & -107 & 0.48 & \\
\hline
\end{tabular}


*Slope is E-10

${ }^{* *}$ Bold and shaded indicate significance was found

\section{A-3 Drain at Terry Street}

Table 17: Summary of linear regression analysis of DO over time on A-3 Drain at Terry Street.

\begin{tabular}{|c|c|c|c|c|c|c|c|}
\hline & & $\mathbf{N}$ & Residual Std. Error & Adjusted $\mathbf{R}^{2}$ & Slope* & Trend p-value & Significant $\Delta$ Slope \\
\hline \multirow{3}{*}{ All Data } & Overall & 83 & 2.87 & 0.01 & -2.34 & 0.30 & \multirow{3}{*}{$\begin{array}{c}\mathrm{NO} \\
p=0.82\end{array}$} \\
\hline & Before & 43 & 3.12 & -0.01 & -49.0 & 0.44 & \\
\hline & After & 40 & 2.63 & -0.01 & -44.5 & 0.47 & \\
\hline \multirow{3}{*}{ Winter } & Overall & 27 & 2.71 & -0.04 & -45.4 & 0.90 & \multirow{3}{*}{$\begin{array}{c}\mathrm{NO} \\
p=0.64\end{array}$} \\
\hline & Before & 12 & 3.55 & -0.05 & 105 & 0.53 & \\
\hline & After & 15 & 1.98 & -0.05 & -37.4 & 0.61 & \\
\hline \multirow{3}{*}{ Spring } & Overall & 18 & 2.18 & -0.05 & -14.8 & 0.70 & \multirow{3}{*}{$\begin{array}{c}\mathrm{NO} \\
p=0.23\end{array}$} \\
\hline & Before & 9 & 2.45 & -0.01 & 114 & 0.37 & \\
\hline & After & 9 & 1.68 & 0.22 & -139 & 0.11 & \\
\hline \multirow{3}{*}{ Summer } & Overall & 21 & 2.68 & 0.24 & -115 & 0.01 & \multirow{3}{*}{$\begin{array}{c}\mathrm{NO} \\
p=0.66\end{array}$} \\
\hline & Before & 12 & 3.35 & 0.05 & -172 & 0.24 & \\
\hline & After & 9 & 1.43 & -0.14 & 2.70 & 0.97 & \\
\hline \multirow{3}{*}{ Fall } & Overall & 17 & 1.70 & -0.06 & 8.56 & 0.80 & \multirow{3}{*}{$\begin{array}{c}\mathrm{NO} \\
p=0.43\end{array}$} \\
\hline & Before & 10 & 1.65 & -0.12 & -11.7 & 0.87 & \\
\hline & After & 7 & 1.80 & 0.01 & -111 & 0.35 & \\
\hline
\end{tabular}

*Slope is E-10

** Bold and shaded indicate significance was found

\section{Lower Amazon}

\section{Amazon Creek at RM 5.82}

Table 18: Summary of linear regression analysis of DO over time on Amazon Creek at RM 5.82.

\begin{tabular}{|c|c|c|c|c|c|c|c|}
\hline & & $\mathbf{N}$ & Residual Std. Error & Adjusted $R^{2}$ & Slope* & Trend $\mathrm{p}$-value & Significant $\Delta$ Slope \\
\hline \multirow{3}{*}{ All Data } & Overall & 6 & 1.49 & 0.20 & 107 & 0.21 & \multirow{3}{*}{$\mathrm{N} / \mathrm{A}$} \\
\hline & Before & 0 & \multicolumn{4}{|c|}{$\mathrm{N} / \mathrm{A}$} & \\
\hline & After & 6 & 1.49 & 0.20 & 107 & 0.21 & \\
\hline \multirow{3}{*}{ Winter } & Overall & 0 & \multirow{3}{*}{\multicolumn{4}{|c|}{$\mathrm{N} / \mathrm{A}$}} & \multirow{3}{*}{$\mathrm{N} / \mathrm{A}$} \\
\hline & Before & 0 & & & & & \\
\hline & After & 0 & & & & & \\
\hline \multirow{3}{*}{ Spring } & Overall & 1 & \multirow{3}{*}{\multicolumn{4}{|c|}{$\mathrm{N} / \mathrm{A}$}} & \multirow{3}{*}{$\mathrm{N} / \mathrm{A}$} \\
\hline & Before & 0 & & & & & \\
\hline & After & 1 & & & & & \\
\hline \multirow{3}{*}{ Summer } & Overall & 4 & 0.52 & 0.89 & 10700 & 0.04 & \multirow{3}{*}{$\mathrm{N} / \mathrm{A}$} \\
\hline & Before & 0 & \multicolumn{4}{|c|}{$\mathrm{N} / \mathrm{A}$} & \\
\hline & After & 4 & 0.52 & 0.89 & 10700 & 0.04 & \\
\hline \multirow{3}{*}{ Fall } & Overall & 1 & \multirow{3}{*}{\multicolumn{4}{|c|}{$\mathrm{N} / \mathrm{A}$}} & \multirow{3}{*}{$\mathrm{N} / \mathrm{A}$} \\
\hline & Before & 0 & & & & & \\
\hline & After & 1 & & & & & \\
\hline
\end{tabular}

*Slope is E-10

** Bold and shaded indicate significance was found

\section{Amazon Creek at High Pass Road}

Table 19: Summary of linear regression analysis of DO over time on Amazon Creek at High Pass Road.

\begin{tabular}{|c|c|c|c|c|c|c|c|}
\hline & & $\mathbf{N}$ & Residual Std. Error & Adjusted $\mathbf{R}^{2}$ & Slope* & Trend p-value & Significant $\Delta$ Slope \\
\hline \multirow{3}{*}{ All Data } & Overall & 37 & 2.12 & -0.01 & 14.9 & 0.42 & \\
\hline & Before & 10 & 1.50 & 0.14 & -998 & 0.15 & \multirow{2}{*}{$\begin{array}{c}\mathrm{NO} \\
p=0.48\end{array}$} \\
\hline & After & 27 & 2.30 & -0.04 & -31.2 & 0.78 & \\
\hline Winter & Overall & 7 & 1.83 & -0.14 & 16.9 & 0.63 & \\
\hline
\end{tabular}




\begin{tabular}{|c|c|c|c|c|c|c|c|}
\hline & Before & 3 & 3.62 & -0.87 & 2520 & 0.83 & NO \\
\hline & After & 4 & 1.17 & -0.50 & 2.58 & 0.99 & $p=0.92$ \\
\hline \multirow{3}{*}{ Spring } & Overall & 10 & 0.75 & 0.05 & -15.4 & 0.26 & \multirow{3}{*}{$\begin{array}{c}\mathrm{NO} \\
p=0.24\end{array}$} \\
\hline & Before & 3 & 0.88 & -0.79 & -773 & 0.79 & \\
\hline & After & 4 & 0.63 & 0.28 & 167 & 0.13 & \\
\hline \multirow{3}{*}{ Summer } & Overall & 10 & 2.15 & -0.10 & 14.9 & 0.66 & \multirow{3}{*}{$\begin{array}{c}\mathrm{NO} \\
p=0.26\end{array}$} \\
\hline & Before & 3 & 1.22 & -0.99 & 203 & 0.96 & \\
\hline & After & 7 & 2.11 & 0.27 & 392 & 0.13 & \\
\hline \multirow{3}{*}{ Fall } & Overall & 10 & 2.57 & 0.22 & -406 & 0.16 & \\
\hline & Before & 1 & \multicolumn{4}{|c|}{$\mathrm{N} / \mathrm{A}$} & \multirow{2}{*}{$\mathrm{N} / \mathrm{A}$} \\
\hline & After & 9 & 2.57 & 0.22 & -406 & 0.16 & \\
\hline
\end{tabular}

*Slope is E-10

${ }^{* *}$ Bold and shaded indicate significance was found

\section{Coyote Creek}

\section{Coyote Creek at Hamm Road}

Table 20: Summary of linear regression analysis of DO over time on Coyote Creek at Hamm Road.

\begin{tabular}{|c|c|c|c|c|c|c|c|}
\hline & & $\mathbf{N}$ & Residual Std. Error & Adjusted $\mathrm{R}^{2}$ & Slope* & Trend p-value & Significant $\Delta$ Slope \\
\hline \multirow{3}{*}{ All Data } & Overall & 26 & 1.12 & 0.35 & -52.8 & 0.01 & \multirow{3}{*}{$N / A$} \\
\hline & Before & 22 & 1.23 & -0.02 & 103 & 0.49 & \\
\hline & After & 4 & 0.46 & 0.78 & 6330 & 0.07 & \\
\hline \multirow{3}{*}{ Winter } & Overall & 6 & 1.68 & -0.21 & 153 & 0.74 & \multirow{3}{*}{$N / A$} \\
\hline & Before & 6 & 1.68 & -0.21 & 153 & 0.74 & \\
\hline & After & 0 & \multicolumn{4}{|c|}{$\mathrm{N} / \mathrm{A}$} & \\
\hline \multirow{3}{*}{ Spring } & Overall & 5 & 0.50 & 0.28 & 243 & 0.21 & \multirow{3}{*}{$N / A$} \\
\hline & Before & 5 & 0.50 & 0.28 & 243 & 0.21 & \\
\hline & After & 0 & & $\mathrm{~N} / \mathrm{A}$ & & & \\
\hline \multirow{3}{*}{ Summer } & Overall & 9 & 0.79 & 0.35 & -25.6 & 0.06 & \multirow{3}{*}{$\begin{array}{c}\text { YES } \\
p=0.09\end{array}$} \\
\hline & Before & 5 & 0.65 & -0.25 & 58.3 & 0.69 & \\
\hline & After & 4 & 0.46 & 0.78 & 6330 & 0.07 & \\
\hline \multirow{3}{*}{ Fall } & Overall & 6 & 0.87 & 0.21 & 336 & 0.20 & \\
\hline & Before & 6 & 0.87 & 0.21 & 336 & 0.20 & \multirow{2}{*}{$\mathrm{N} / \mathrm{A}$} \\
\hline & After & 0 & \multicolumn{4}{|c|}{$\mathrm{N} / \mathrm{A}$} & \\
\hline
\end{tabular}

*Slope is E-10

** Bold and shaded indicate significance was found

\section{Coyote Creek at Powell Road}

Table 21: Summary of linear regression analysis of DO over time on Coyote Creek at Powell Road.

\begin{tabular}{|c|c|c|c|c|c|c|c|}
\hline & & $\mathbf{N}$ & Residual Std. Error & Adjusted $\mathrm{R}^{2}$ & Slope* & Trend p-value & Significant $\Delta$ Slope \\
\hline \multirow{3}{*}{ All Data } & Overall & 43 & 1.38 & 0.10 & -37.0 & 0.02 & \multirow{3}{*}{$\mathrm{N} / \mathrm{A}$} \\
\hline & Before & 39 & 1.43 & -0.02 & -17.7 & 0.77 & \\
\hline & After & 4 & 0.14 & 0.98 & 6180 & 0.01 & \\
\hline \multirow{3}{*}{ Winter } & Overall & 9 & 0.68 & -0.13 & -16.3 & 0.78 & \multirow{3}{*}{$\mathrm{N} / \mathrm{A}$} \\
\hline & Before & 9 & 0.68 & -0.13 & -16.3 & 0.78 & \\
\hline & After & 0 & \multicolumn{4}{|c|}{$\mathrm{N} / \mathrm{A}$} & \\
\hline \multirow{3}{*}{ Spring } & Overall & 8 & 0.82 & -0.13 & -30.6 & 0.67 & \multirow{3}{*}{$\mathrm{N} / \mathrm{A}$} \\
\hline & Before & 8 & 0.82 & -0.13 & -30.6 & 0.67 & \\
\hline & After & 0 & & $\mathrm{~N} / \mathrm{A}$ & & & \\
\hline \multirow{3}{*}{ Summer } & Overall & 17 & 0.80 & -0.04 & -5.82 & 0.57 & \multirow{3}{*}{$\begin{array}{c}\mathrm{NO} \\
p=0.84\end{array}$} \\
\hline & Before & 13 & 0.79 & -0.06 & -43.8 & 0.56 & \\
\hline & After & 4 & 0.14 & 0.98 & 6180 & 0.01 & \\
\hline \multirow{3}{*}{ Fall } & Overall & 9 & 1.29 & -0.10 & 58.3 & 0.61 & \multirow{3}{*}{$\mathrm{N} / \mathrm{A}$} \\
\hline & Before & 9 & 1.29 & -0.10 & 58.3 & 0.61 & \\
\hline & After & 0 & \multicolumn{4}{|c|}{$\mathrm{N} / \mathrm{A}$} & \\
\hline
\end{tabular}


${ }^{*}$ Slope is E-10

${ }^{* *}$ Bold and shaded indicate significance was found

\section{Coyote Creek at Petzold Road}

Table 22: Summary of linear regression analysis of DO over time on Coyote Creek at Petzold Road.

\begin{tabular}{|c|c|c|c|c|c|c|c|}
\hline & & $\mathbf{N}$ & Residual Std. Error & Adjusted $\mathrm{R}^{2}$ & Slope $^{*}$ & Trend p-value & Significant $\Delta$ Slope \\
\hline \multirow{3}{*}{ All Data } & Overall & 42 & 2.23 & 0.15 & -86.7 & 0.01 & \\
\hline & Before & 39 & 2.27 & -0.02 & 36.6 & 0.78 & \multirow{2}{*}{$\mathrm{N} / \mathrm{A}$} \\
\hline & After & 3 & 1.85 & -0.81 & 3890 & 0.80 & \\
\hline \multirow{3}{*}{ Winter } & Overall & 9 & 0.66 & 0.24 & -161 & 0.10 & \multirow{3}{*}{$\mathrm{N} / \mathrm{A}$} \\
\hline & Before & 9 & 0.66 & 0.24 & -161 & 0.10 & \\
\hline & After & 0 & \multicolumn{4}{|c|}{$\mathrm{N} / \mathrm{A}$} & \\
\hline \multirow{3}{*}{ Spring } & Overall & 8 & 0.87 & 0.12 & -174 & 0.21 & \multirow{3}{*}{$\mathrm{N} / \mathrm{A}$} \\
\hline & Before & 8 & 0.87 & 0.12 & -174 & 0.21 & \\
\hline & After & 0 & \multicolumn{4}{|c|}{$\mathrm{N} / \mathrm{A}$} & \\
\hline \multirow{3}{*}{ Summer } & Overall & 15 & 1.05 & 0.30 & -40.3 & 0.02 & \multirow{3}{*}{$\begin{array}{c}\mathrm{NO} \\
p=0.13\end{array}$} \\
\hline & Before & 12 & 1.02 & -0.06 & -705 & 0.55 & \\
\hline & After & 3 & 1.85 & -0.81 & 3890 & 0.80 & \\
\hline \multirow{3}{*}{ Fall } & Overall & 10 & 2.56 & -0.11 & 70.9 & 0.79 & \multirow{3}{*}{$\mathrm{N} / \mathrm{A}$} \\
\hline & Before & 0 & 2.56 & -0.11 & 70.9 & 0.79 & \\
\hline & After & 0 & \multicolumn{4}{|c|}{$\mathrm{N} / \mathrm{A}$} & \\
\hline
\end{tabular}

*Slope is E-10

** Bold and shaded indicate significance was found 


\section{Appendix E}

ARIMA forecast Models 


\section{Bacteria (E. coli)}

\section{Upper Amazon}

\section{Amazon Creek at $2^{\text {th }}$ Avenue}

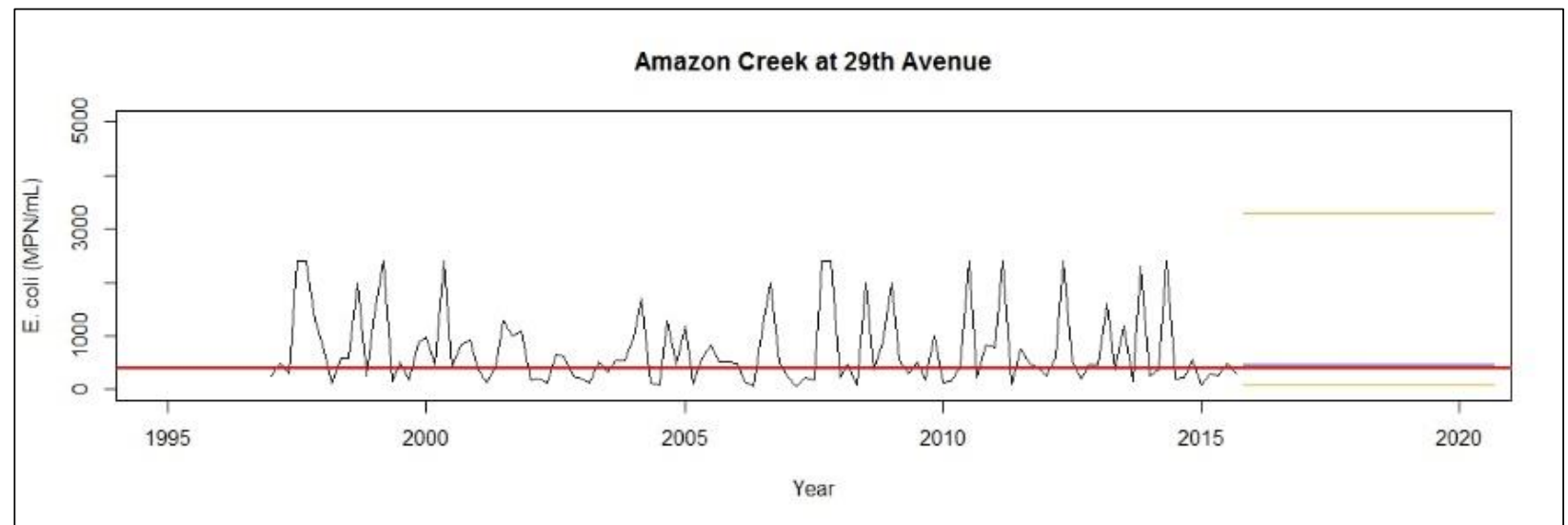

Figure 1: Forecasted E. coli concentration levels through 2020. The blue line indicates the forecasted mean. The orange lines indicate the upper and lower 95\% confidence interval. The horizontal red line is State single sample exceedance level (406 E. coli organisms (MPN)/100 ml).

\section{Amazon Creek at Railroad Crossing}

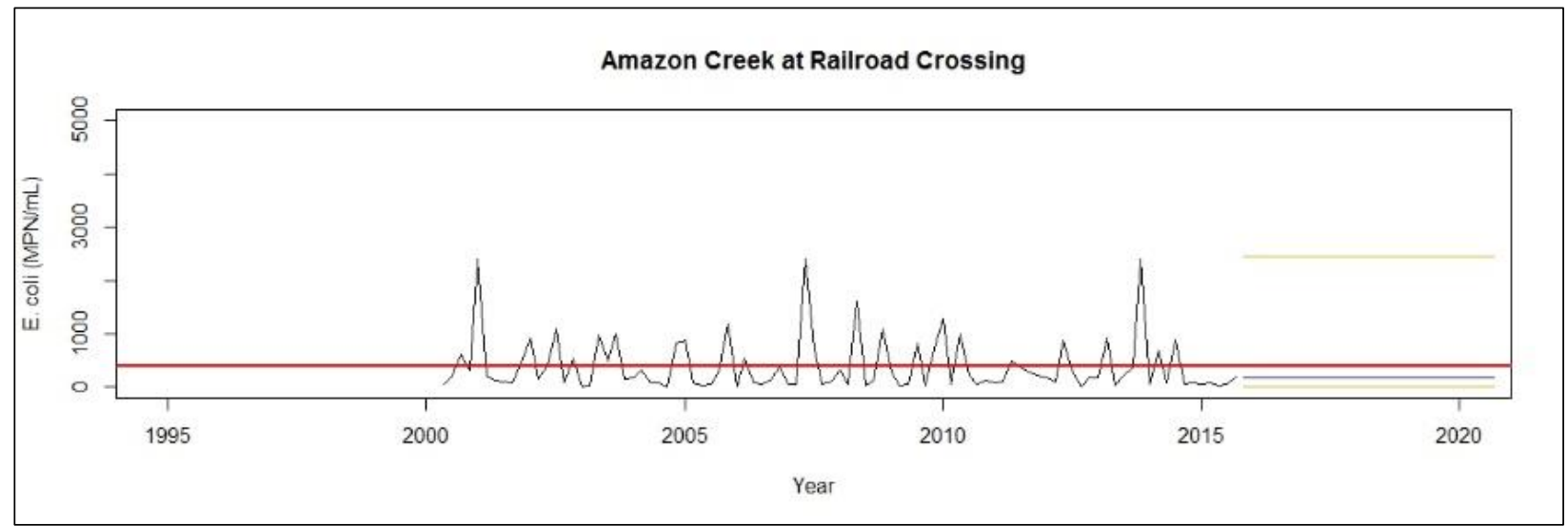

Figure 2: Forecasted E. coli concentration levels through 2020. The blue line indicates the forecasted mean. The orange lines indicate the upper and lower 95\% confidence interval. The horizontal red line is State single sample exceedance level (406 E. coli organisms (MPN)/100 ml).

\section{Amazon Creek at Royal Avenue}




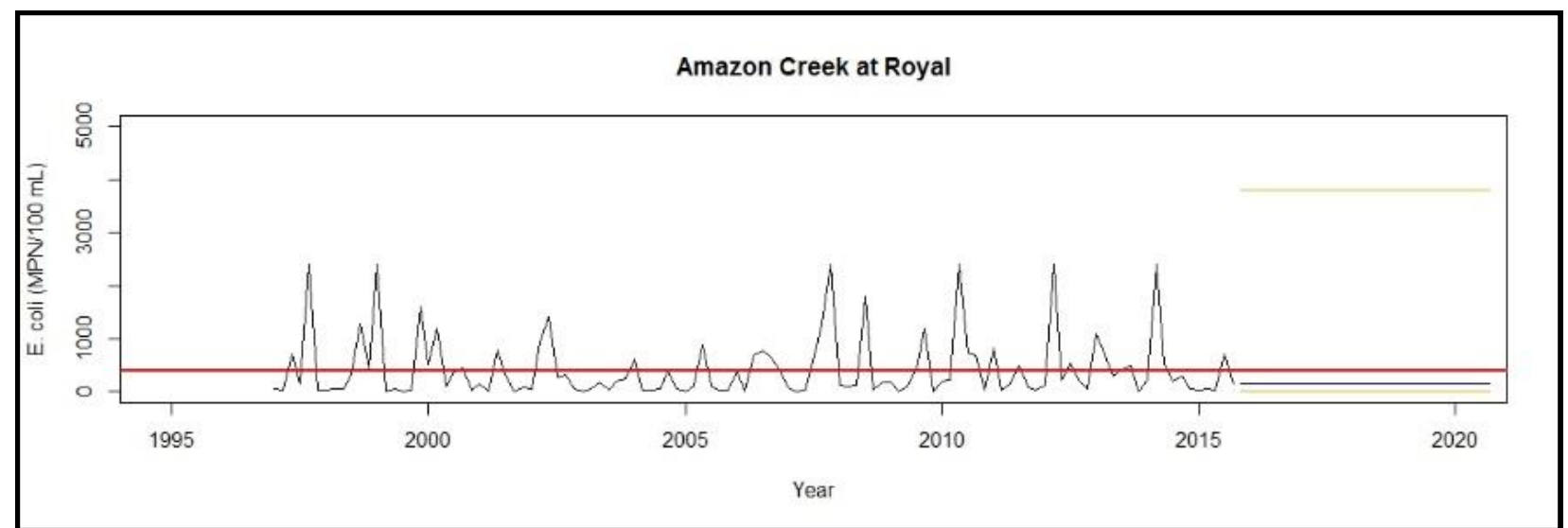

Figure 3: Forecasted E. coli concentration levels through 2020. The blue line indicates the forecasted mean. The orange lines indicate the upper and lower 95\% confidence interval. The horizontal red line is State single sample exceedance level (406 E. coli organisms (MPN)/100 ml).

\section{Amazon Diversion Channel at Royal Avenue}

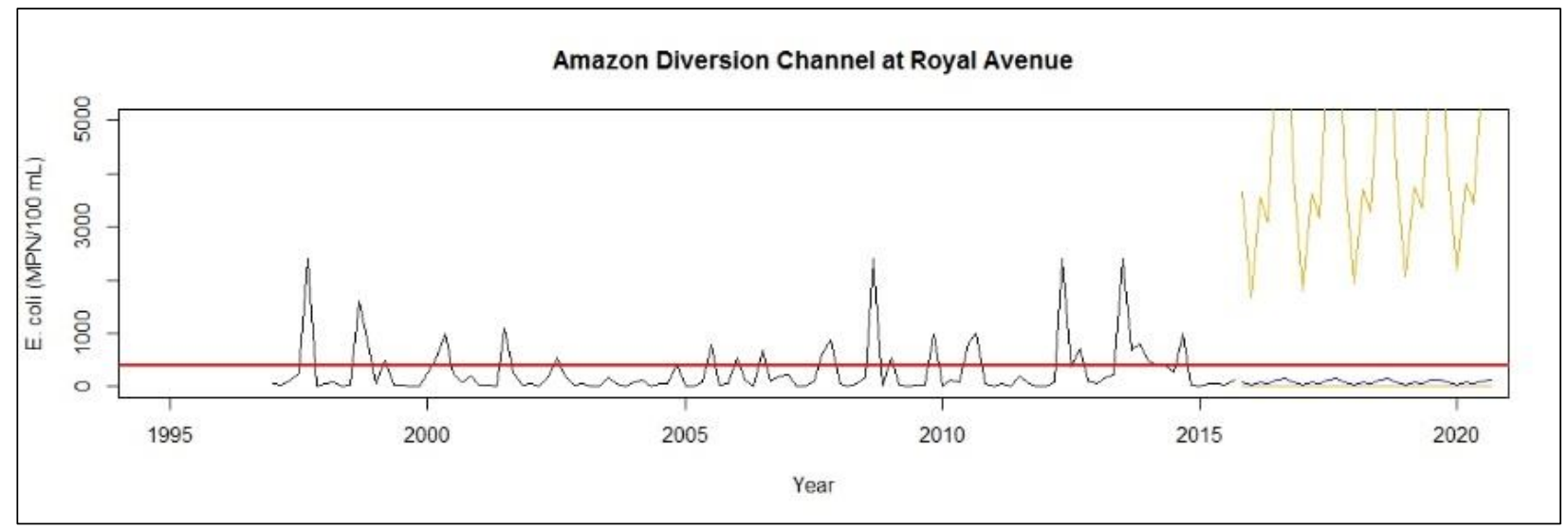

Figure 4: Forecasted $E$. coli concentration levels through 2020. The blue line indicates the forecasted mean. The orange lines indicate the upper and lower $95 \%$ confidence interval. The horizontal red line is State single sample exceedance level (406 E. coli organisms (MPN)/100 ml).

\section{A-3 Drain at Terry Street}

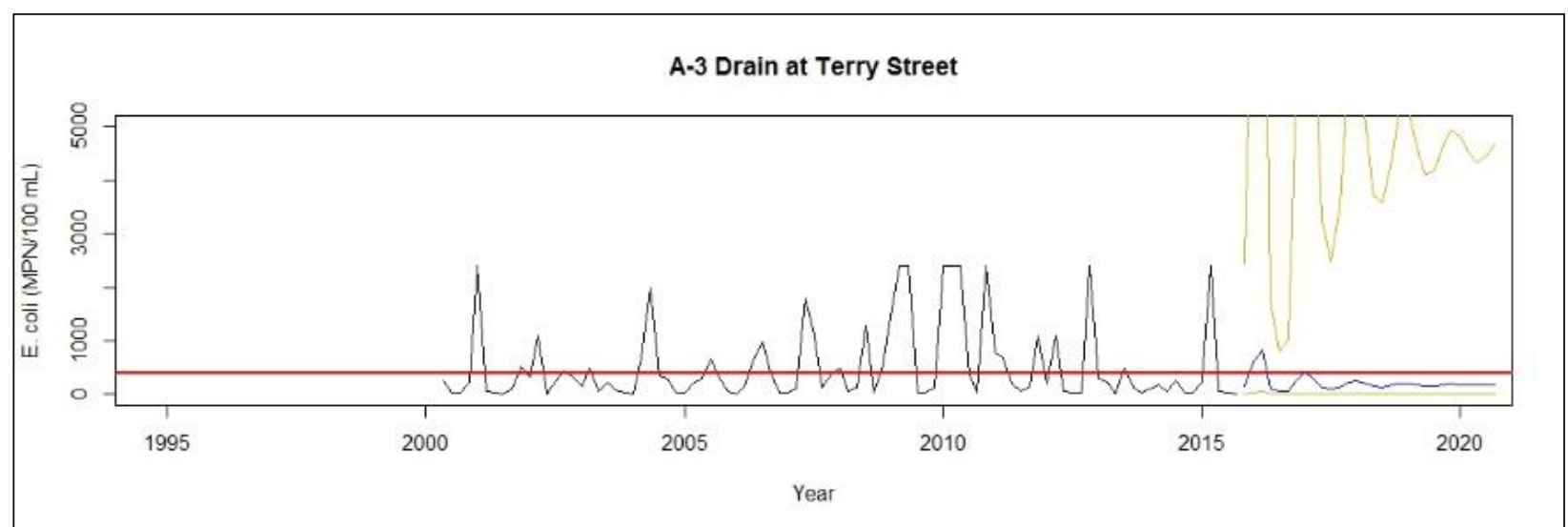

Figure 5: Forecasted E. coli concentration levels through 2020. The blue line indicates the forecasted mean. The orange lines indicate the upper and lower $95 \%$ confidence interval. The horizontal red line is State single sample exceedance level (406 E. coli organisms (MPN)/100 ml). 


\section{Dissolved Oxygen}

\section{Upper Amazon}

\section{Amazon Creek at $29^{\text {th }}$ Avenue}

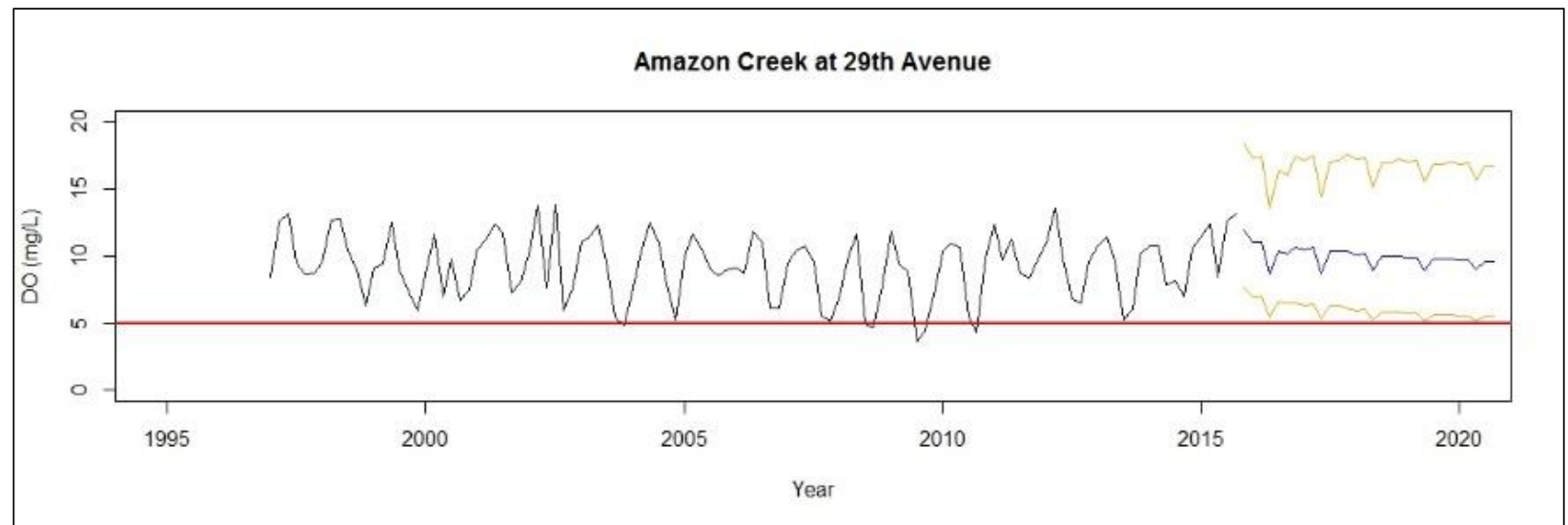

Figure 6: Forecasted DO concentration levels through 2020. The blue line indicates the forecasted mean. The orange lines indicate the upper and lower $95 \%$ confidence interval. The horizontal red line is State single sample exceedance level (5.0 mg/L).

\section{Amazon Creek at Railroad Crossing}

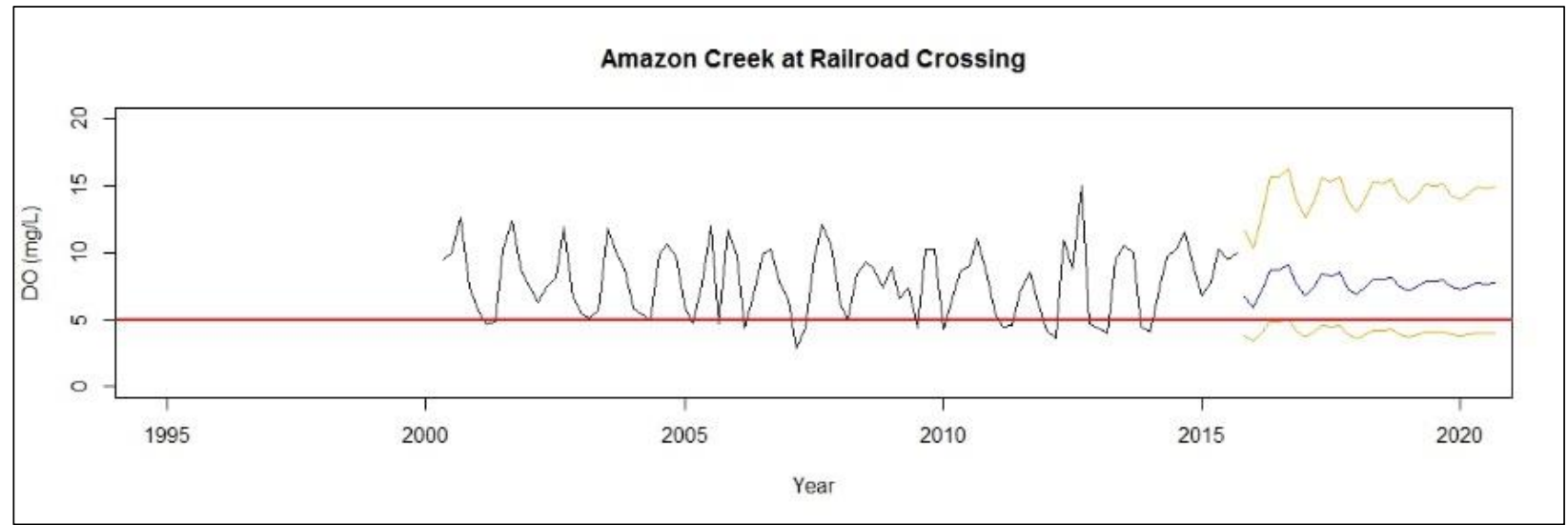

Figure 7: Forecasted DO concentration levels through 2020. The blue line indicates the forecasted mean. The orange lines indicate the upper and lower $95 \%$ confidence interval. The horizontal red line is State single sample exceedance level (5.0 mg/L).

\section{Amazon Creek at Royal Avenue}




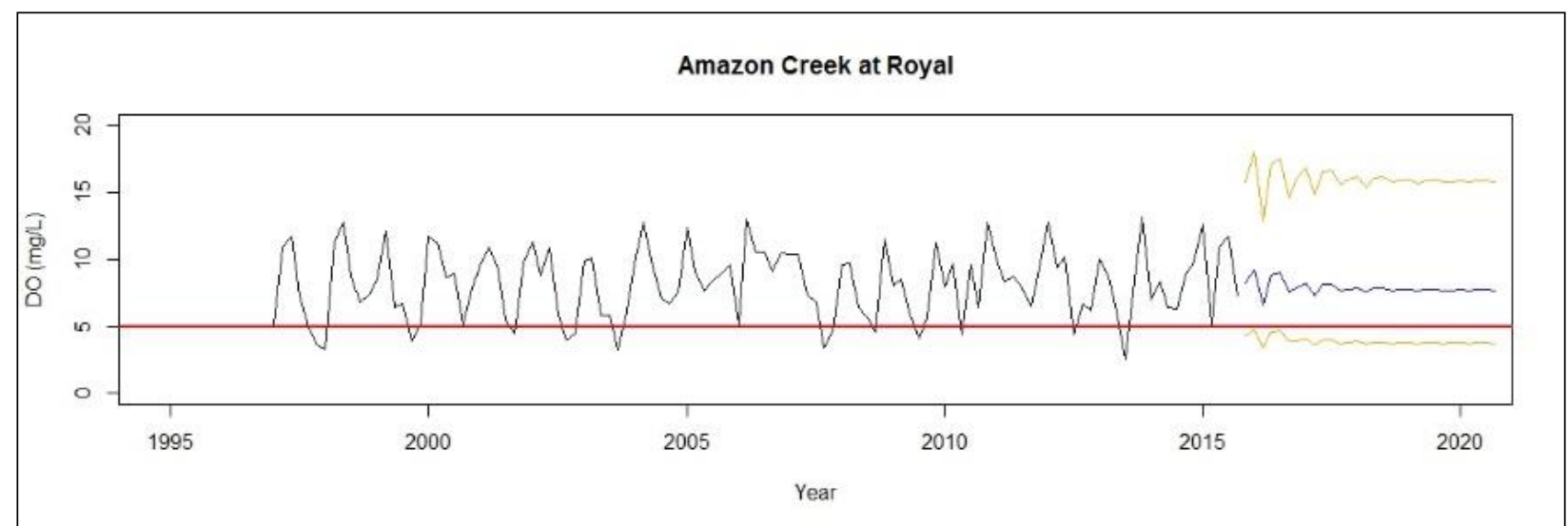

Figure 8: Forecasted DO concentration levels through 2020. The blue line indicates the forecasted mean. The orange lines indicate the upper and lower $95 \%$ confidence interval. The horizontal red line is State single sample exceedance level (5.0 mg/L).

\section{Amazon Diversion Channel at Royal Avenue}

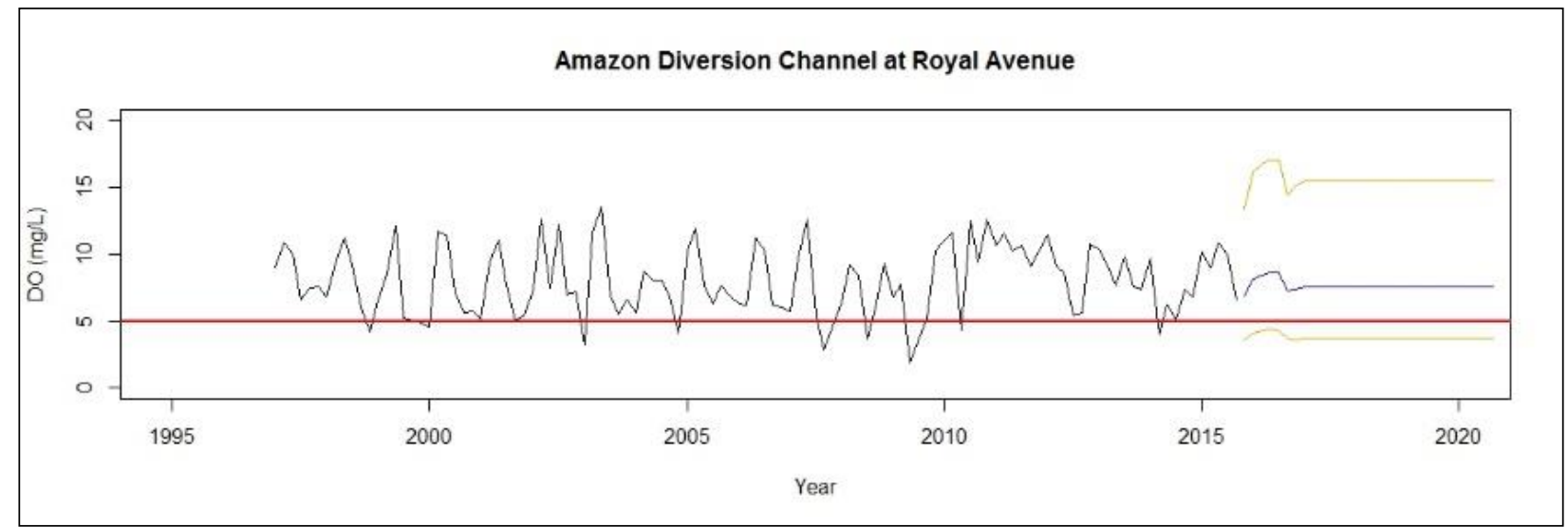

Figure 9: Forecasted DO concentration levels through 2020. The blue line indicates the forecasted mean. The orange lines indicate the upper and lower $95 \%$ confidence interval. The horizontal red line is State single sample exceedance level $(5.0 \mathrm{mg} / \mathrm{L})$.

\section{A-3 Drain at Terry Street}

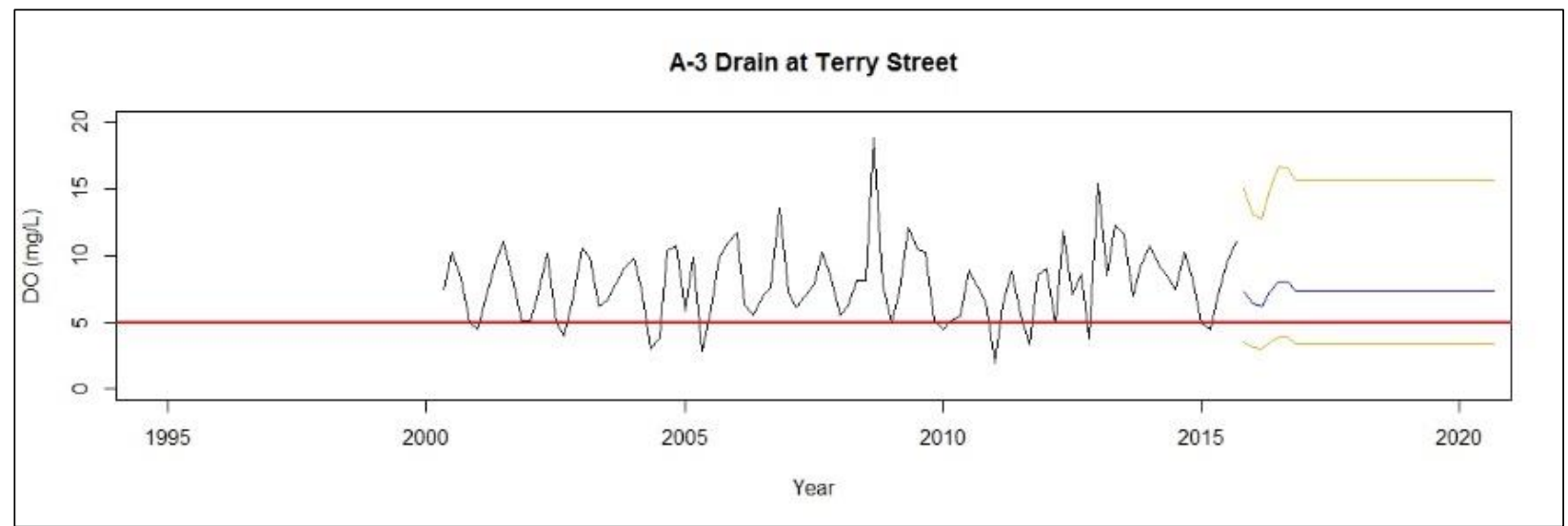

Figure 10: Forecasted DO concentration levels through 2020. The blue line indicates the forecasted mean. The orange lines indicate the upper and lower $95 \%$ confidence interval. The horizontal red line is State single sample exceedance level (5.0 mg/L). 


\section{Appendix F Tested Parameters Data Summaries}




\section{Amazon Creek at $29^{\text {th }}$ Avenue}

\section{Ammonia}

Table 1: Overall and seasonal ammonia ( $\mathrm{mg} / \mathrm{L})$ data summary on Amazon creek at $29^{\text {th }}$ Avenue, before and after 2008 \begin{tabular}{|l|l|l|l|l|}
\hline & Minimum & Geometric Mean & Maximum & $\%$ Change in Mean \\
\hline
\end{tabular}

\begin{tabular}{|c|c|c|c|c|}
\hline \multicolumn{5}{|l|}{ All Data } \\
\hline Before & 0.05 & 0.06 & 0.30 & \multirow{2}{*}{$-17 \%$} \\
\hline After & 0.05 & 0.05 & 0.05 & \\
\hline \multicolumn{5}{|l|}{ Winter } \\
\hline Before & 0.05 & 0.05 & 0.05 & \multirow{2}{*}{$0 \%$} \\
\hline After & 0.05 & 0.05 & 0.05 & \\
\hline \multicolumn{5}{|l|}{ Spring } \\
\hline Before & 0.05 & 0.05 & 0.05 & \multirow{2}{*}{$0 \%$} \\
\hline After & 0.05 & 0.05 & 0.05 & \\
\hline \multicolumn{5}{|l|}{ Summer } \\
\hline Before & 0.05 & 0.05 & 0.10 & \multirow{2}{*}{$0 \%$} \\
\hline After & 0.05 & 0.05 & 0.05 & \\
\hline \multicolumn{5}{|l|}{ Fall } \\
\hline Before & 0.05 & 0.07 & 0.30 & \multirow{2}{*}{$-29 \%$} \\
\hline After & 0.05 & 0.05 & 0.05 & \\
\hline
\end{tabular}

\section{Temperature}

Table 2: Overall and seasonal temperature $\left({ }^{\circ} \mathrm{C}\right)$ data summary on Amazon creek at $29^{\text {th }}$ Avenue, before and after 2008

\begin{tabular}{|c|c|c|c|c|}
\hline & Minimum & Geometric Mean & Maximum & $\%$ Change in Mean \\
\hline \multicolumn{5}{|l|}{ All Data } \\
\hline Before & 4.2 & 11.8 & 18.4 & \multirow{2}{*}{$0.0 \%$} \\
\hline After & 5.2 & 11.8 & 18.2 & \\
\hline \multicolumn{5}{|l|}{ Winter } \\
\hline Before & 4.2 & 8.2 & 11.3 & \multirow{2}{*}{$-6 \%$} \\
\hline After & 5.2 & 7.7 & 10.2 & \\
\hline \multicolumn{5}{|l|}{ Spring } \\
\hline Before & 9.5 & 12.6 & 15.4 & \multirow{2}{*}{$-3 \%$} \\
\hline After & 7.8 & 12.2 & 14.7 & \\
\hline \multicolumn{5}{|l|}{ Summer } \\
\hline Before & 11.4 & 15.9 & 18.4 & \multirow{2}{*}{$+6 \%$} \\
\hline After & 15.1 & 16.9 & 19.9 & \\
\hline \multicolumn{5}{|l|}{ Fall } \\
\hline Before & 6.8 & 9.9 & 14.2 & \multirow{2}{*}{$+20 \%$} \\
\hline After & 8.2 & 11.9 & 14.3 & \\
\hline
\end{tabular}

\section{Nitrate/Nitrite as $\mathbf{N}$}

Table 3: Overall and seasonal Nitrate/Nitrite as N (mg/L) data summary on Amazon creek at $29^{\text {th }}$ Avenue, before and after 2008

\begin{tabular}{|c|c|c|c|c|}
\hline & Minimum & Geometric Mean & Maximum & $\%$ Change in Mean \\
\hline \multicolumn{5}{|l|}{ All Data } \\
\hline Before & 0.03 & 0.33 & 1.5 & \multirow{2}{*}{$+9 \%$} \\
\hline After & 0.08 & 0.36 & 2.7 & \\
\hline \multicolumn{5}{|l|}{ Winter } \\
\hline Before & 0.3 & 0.33 & 0.54 & \multirow{2}{*}{$+18 \%$} \\
\hline After & 0.21 & 0.39 & 1.10 & \\
\hline \multicolumn{5}{|l|}{ Spring } \\
\hline Before & 0.10 & 0.26 & 0.48 & \multirow{2}{*}{$+77 \%$} \\
\hline After & 0.11 & 0.46 & 2.70 & \\
\hline \multicolumn{5}{|l|}{ Summer } \\
\hline Before & 0.03 & 0.29 & 1.10 & \multirow{2}{*}{$-14 \%$} \\
\hline After & 0.08 & 0.25 & 0.83 & \\
\hline \multicolumn{5}{|l|}{ Fall } \\
\hline Before & 0.09 & 0.46 & 1.50 & \multirow{2}{*}{$-13 \%$} \\
\hline After & 0.12 & 0.40 & 0.79 & \\
\hline
\end{tabular}




\section{Ortho-phosphorus}

Table 4: Overall and seasonal Ortho-phosphorus (mg/L) data summary on Amazon creek at $29^{\text {th }}$ Avenue, before and after 2008

\begin{tabular}{|c|c|c|c|c|}
\hline & Minimum & Geometric Mean & Maximum & $\%$ Change in Mean \\
\hline \multicolumn{5}{|l|}{ All Data } \\
\hline Before & 0.01 & 0.06 & 0.32 & \multirow{2}{*}{$0 \%$} \\
\hline After & 0.02 & 0.06 & 0.20 & \\
\hline \multicolumn{5}{|l|}{ Winter } \\
\hline Before & 0.01 & 0.05 & 0.08 & \multirow{2}{*}{$-20 \%$} \\
\hline After & 0.02 & 0.04 & 0.07 & \\
\hline \multicolumn{5}{|l|}{ Spring } \\
\hline Before & 0.02 & 0.06 & 0.32 & \multirow{2}{*}{$-33 \%$} \\
\hline After & 0.03 & 0.04 & 0.07 & \\
\hline \multicolumn{5}{|l|}{ Summer } \\
\hline Before & 0.04 & 0.07 & 0.15 & \multirow{2}{*}{$+14 \%$} \\
\hline After & 0.04 & 0.08 & 0.20 & \\
\hline \multicolumn{5}{|l|}{ Fall } \\
\hline Before & 0.03 & 0.07 & 0.10 & \multirow{2}{*}{$-14 \%$} \\
\hline After & 0.05 & 0.06 & 0.09 & \\
\hline
\end{tabular}

\section{Total Phosphorus}

Table 5: Overall and seasonal Total Phosphorus (mg/L) data summary on Amazon creek at $29^{\text {th }}$ Avenue, before and after 2008

\begin{tabular}{|c|c|c|c|c|}
\hline & Minimum & Geometric Mean & Maximum & $\%$ Change in Mean \\
\hline \multicolumn{5}{|l|}{ All Data } \\
\hline Before & 0.02 & 0.11 & 0.40 & \multirow{2}{*}{$-9 \%$} \\
\hline After & 0.01 & 0.10 & 0.24 & \\
\hline \multicolumn{5}{|l|}{ Winter } \\
\hline Before & 0.04 & 0.11 & 0.22 & \multirow{2}{*}{$-18 \%$} \\
\hline After & 0.01 & 0.09 & 0.24 & \\
\hline \multicolumn{5}{|l|}{ Spring } \\
\hline Before & 0.02 & 0.09 & 0.40 & \multirow{2}{*}{$-33 \%$} \\
\hline After & 0.03 & 0.06 & 0.10 & \\
\hline \multicolumn{5}{|l|}{ Summer } \\
\hline Before & 0.05 & 0.13 & 0.38 & \multirow{2}{*}{$-8 \%$} \\
\hline After & 0.08 & 0.12 & 0.23 & \\
\hline \multicolumn{5}{|l|}{ Fall } \\
\hline Before & 0.04 & 0.12 & 0.38 & \multirow{2}{*}{$-17 \%$} \\
\hline After & 0.06 & 0.10 & 0.20 & \\
\hline
\end{tabular}

\section{Total Suspended Solids (TSS)}

Table 6: Overall and seasonal TSS (mg/L) data summary on Amazon creek at $29^{\text {th }}$ Avenue, before and after 2008

\begin{tabular}{|c|c|c|c|c|}
\hline 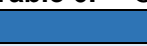 & Minimum & Geometric Mean & Maximum & $\%$ Change in Mean \\
\hline \multicolumn{5}{|l|}{ All Data } \\
\hline Before & 0.5 & 8.1 & 57.0 & \multirow{2}{*}{$+15 \%$} \\
\hline After & 1.0 & 9.3 & 83.0 & \\
\hline \multicolumn{5}{|l|}{ Winter } \\
\hline Before & 3.0 & 11.7 & 42.0 & \multirow{2}{*}{$+57 \%$} \\
\hline After & 1.0 & 18.4 & 83.0 & \\
\hline \multicolumn{5}{|l|}{ Spring } \\
\hline Before & 2.0 & 9.2 & 57.0 & \multirow{2}{*}{$-67 \%$} \\
\hline After & 2.0 & 3.0 & 6.0 & \\
\hline \multicolumn{5}{|l|}{ Summer } \\
\hline Before & 2.0 & 5.7 & 19.0 & \multirow{2}{*}{$+26 \%$} \\
\hline After & 1.0 & 7.2 & 18.0 & \\
\hline \multicolumn{5}{|l|}{ Fall } \\
\hline Before & 0.5 & 5.8 & 13.0 & \multirow{2}{*}{$-60 \%$} \\
\hline After & 1.0 & 2.3 & 4.0 & \\
\hline
\end{tabular}

\section{Biological Oxygen Demand (BOD)}

Table 7: Overall and seasonal BOD (mg/L) data summary on Amazon creek at $29^{\text {th }}$ Avenue, before and after 2008 


\begin{tabular}{|c|c|c|c|c|}
\hline & Minimum & Geometric Mean & Maximum & $\%$ Change in Mean \\
\hline \multicolumn{5}{|l|}{ All Data } \\
\hline Before & 1.0 & 3.0 & 24.0 & \multirow{2}{*}{$+97 \%$} \\
\hline After & 1.0 & 5.9 & 43.0 & \\
\hline \multicolumn{5}{|l|}{ Winter } \\
\hline Before & 1.0 & 1.3 & 6.0 & \multirow{2}{*}{$-15 \%$} \\
\hline After & 1.0 & 1.1 & 2.0 & \\
\hline \multicolumn{5}{|l|}{ Spring } \\
\hline Before & 1.0 & 1.1 & 2.0 & \multirow{2}{*}{$-9 \%$} \\
\hline After & 1.0 & 1.0 & 1.0 & \\
\hline \multicolumn{5}{|l|}{ Summer } \\
\hline Before & 1.0 & 1.6 & 9.0 & \multirow{2}{*}{$+31 \%$} \\
\hline After & 1.0 & 2.1 & 9.0 & \\
\hline \multicolumn{5}{|l|}{ Fall } \\
\hline Before & 1.0 & 1.1 & 2.0 & \multirow{2}{*}{$-9 \%$} \\
\hline After & 1.0 & 1.0 & 1.0 & \\
\hline
\end{tabular}

\section{Chemical Oxygen Demand (COD)}

Table 8: Overall and seasonal COD (mg/L) data summary on Amazon creek at $29^{\text {th }}$ Avenue, before and after 2008

\begin{tabular}{|c|c|c|c|c|}
\hline & Minimum & Geometric Mean & Maximum & $\%$ Change in Mean \\
\hline \multicolumn{5}{|l|}{ All Data } \\
\hline Before & 1.0 & 6.5 & 35.0 & \multirow{2}{*}{$+31 \%$} \\
\hline After & 1.0 & 8.5 & 41.0 & \\
\hline \multicolumn{5}{|l|}{ Winter } \\
\hline Before & 5.0 & 7.5 & 24.0 & \multirow{2}{*}{$+96 \%$} \\
\hline After & 2.5 & 14.7 & 43.0 & \\
\hline \multicolumn{5}{|l|}{ Spring } \\
\hline Before & 5.0 & 8.4 & 16.0 & \multirow{2}{*}{$-12 \%$} \\
\hline After & 2.5 & 7.4 & 18.0 & \\
\hline \multicolumn{5}{|l|}{ Summer } \\
\hline Before & 5.0 & 8.7 & 35.0 & \multirow{2}{*}{$+74 \%$} \\
\hline After & 2.5 & 15.1 & 41.0 & \\
\hline \multicolumn{5}{|l|}{ Fall } \\
\hline Before & 5.0 & 8.2 & 16.0 & \multirow{2}{*}{$+50 \%$} \\
\hline After & 5.0 & 12.3 & 17.0 & \\
\hline
\end{tabular}

\section{Amazon Creek at Railroad Crossing}

\section{Ammonia}

Table 9: Overall and seasonal ammonia ( $\mathrm{mg} / \mathrm{L}$ ) data summary on Amazon Creek at Railroad Crossing, before and after 2008

\begin{tabular}{|c|c|c|c|c|}
\hline 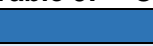 & Minimum & Geometric Mean & Maximum & $\%$ Change in Mean \\
\hline \multicolumn{5}{|l|}{ All Data } \\
\hline Before & 0.00 & 0.05 & 0.20 & \multirow{2}{*}{$+40 \%$} \\
\hline After & 0.05 & 0.07 & 0.60 & \\
\hline \multicolumn{5}{|l|}{ Winter } \\
\hline Before & 0.05 & 0.06 & 0.20 & \multirow{2}{*}{$-17 \%$} \\
\hline After & 0.05 & 0.05 & 0.05 & \\
\hline \multicolumn{5}{|l|}{ Spring } \\
\hline Before & 0.05 & 0.05 & 0.05 & \multirow{2}{*}{$0 \%$} \\
\hline After & 0.05 & 0.05 & 0.05 & \\
\hline \multicolumn{5}{|l|}{ Summer } \\
\hline Before & 0.05 & 0.05 & 0.05 & \multirow{2}{*}{$+80 \%$} \\
\hline After & 0.05 & 0.09 & 0.60 & \\
\hline \multicolumn{5}{|l|}{ Fall } \\
\hline Before & 0.05 & 0.05 & 0.05 & \multirow{2}{*}{$+80 \%$} \\
\hline After & 0.05 & 0.09 & 0.30 & \\
\hline
\end{tabular}

\section{Temperature}

Table 10: Overall and seasonal temperature $\left({ }^{\circ} \mathrm{C}\right)$ data summary on Amazon Creek at Railroad Crossing, before and after 2008 \begin{tabular}{|l|l|l|l|l|}
\hline & Minimum & Geometric Mean & Maximum & $\%$ Change in Mean \\
\hline
\end{tabular} 


\begin{tabular}{|c|c|c|c|c|}
\hline All Data & & & & \multirow{3}{*}{$-7 \%$} \\
\hline Before & 5.7 & 14.4 & 25.2 & \\
\hline After & 3.7 & 13.4 & 24.1 & \\
\hline \multicolumn{5}{|l|}{ Winter } \\
\hline Before & 7.4 & 9.4 & 13.3 & \multirow{2}{*}{$-22 \%$} \\
\hline After & 3.7 & 7.3 & 10.8 & \\
\hline \multicolumn{5}{|l|}{ Spring } \\
\hline Before & 11.4 & 18.0 & 22.6 & \multirow{2}{*}{$-16 \%$} \\
\hline After & 8.3 & 15.2 & 18.9 & \\
\hline \multicolumn{5}{|l|}{ Summer } \\
\hline Before & 15.7 & 20.2 & 25.2 & \multirow{2}{*}{$-1 \%$} \\
\hline After & 15.4 & 20.0 & 24.1 & \\
\hline \multicolumn{5}{|l|}{ Fall } \\
\hline Before & 5.7 & 9.7 & 15.8 & \multirow{2}{*}{$+14 \%$} \\
\hline After & 7.4 & 11.1 & 13.9 & \\
\hline
\end{tabular}

\section{Nitrate/Nitrite as $\mathbf{N}$}

Table 11: Overall and seasonal Nitrate/Nitrite as $\mathrm{N}(\mathrm{mg} / \mathrm{L})$ data summary on Amazon Creek at Railroad Crossing, before and after 2008

\begin{tabular}{|c|c|c|c|c|}
\hline & Minimum & Geometric Mean & Maximum & $\%$ Change in Mean \\
\hline \multicolumn{5}{|l|}{ All Data } \\
\hline Before & 0.03 & 0.25 & 0.79 & \multirow{2}{*}{$+20 \%$} \\
\hline After & 0.03 & 0.30 & 1.20 & \\
\hline \multicolumn{5}{|l|}{ Winter } \\
\hline Before & 0.03 & 0.28 & 0.56 & \multirow{2}{*}{$+21 \%$} \\
\hline After & 0.18 & 0.34 & 0.63 & \\
\hline \multicolumn{5}{|l|}{ Spring } \\
\hline Before & 0.03 & 0.17 & 0.31 & \multirow{2}{*}{$-6 \%$} \\
\hline After & 0.03 & 0.16 & 0.33 & \\
\hline \multicolumn{5}{|l|}{ Summer } \\
\hline Before & 0.03 & 0.08 & 0.36 & \multirow{2}{*}{$+113 \%$} \\
\hline After & 0.03 & 0.17 & 0.84 & \\
\hline \multicolumn{5}{|l|}{ Fall } \\
\hline Before & 0.03 & 0.49 & 0.79 & \multirow{2}{*}{$+29 \%$} \\
\hline After & 0.12 & 0.63 & 1.20 & \\
\hline
\end{tabular}

\section{Ortho-phosphorus}

Table 12: Overall and seasonal Ortho-phosphorus ( $\mathrm{mg} / \mathrm{L}$ ) data summary on Amazon Creek at Railroad Crossing, before and after 2008

\begin{tabular}{|c|c|c|c|c|}
\hline & Minimum & Geometric Mean & Maximum & $\%$ Change in Mean \\
\hline \multicolumn{5}{|l|}{ All Data } \\
\hline Before & 0.01 & 0.05 & 0.34 & \multirow{2}{*}{$-20 \%$} \\
\hline After & 0.01 & 0.04 & 0.18 & \\
\hline \multicolumn{5}{|l|}{ Winter } \\
\hline Before & 0.01 & 0.06 & 0.10 & \multirow{2}{*}{$-50 \%$} \\
\hline After & 0.01 & 0.03 & 0.08 & \\
\hline \multicolumn{5}{|l|}{ Spring } \\
\hline Before & 0.01 & 0.04 & 0.11 & \multirow{2}{*}{$0 \%$} \\
\hline After & 0.04 & 0.04 & 0.18 & \\
\hline \multicolumn{5}{|l|}{ Summer } \\
\hline Before & 0.01 & 0.04 & 0.24 & \multirow{2}{*}{$-25 \%$} \\
\hline After & 0.01 & 0.03 & 0.12 & \\
\hline \multicolumn{5}{|l|}{ Fall } \\
\hline Before & 0.01 & 0.05 & 0.34 & \multirow{2}{*}{$0 \%$} \\
\hline After & 0.03 & 0.05 & 0.07 & \\
\hline
\end{tabular}

\section{Total Phosphorus}

Table 13: Overall and seasonal Total Phosphorus (mg/L) data summary on Amazon creek at Railroad Crossing, before and after 2008

\begin{tabular}{|c|c|c|c|c|}
\hline & Minimum & Geometric Mean & Maximum & $\%$ Change in Mean \\
\hline All Data & 0.03 & 0.11 & 0.28 & $+9 \%$ \\
\hline Before & 0.03 &
\end{tabular}




\begin{tabular}{|c|c|c|c|c|}
\hline After & 0.02 & 0.12 & 0.34 & \\
\hline \multicolumn{5}{|l|}{ Winter } \\
\hline Before & 0.04 & 0.08 & 0.17 & \multirow{2}{*}{$0 \%$} \\
\hline After & 0.02 & 0.08 & 0.18 & \\
\hline \multicolumn{5}{|l|}{ Spring } \\
\hline Before & 0.04 & 0.14 & 0.20 & \multirow{2}{*}{$-21 \%$} \\
\hline After & 0.03 & 0.11 & 0.17 & \\
\hline \multicolumn{5}{|l|}{ Summer } \\
\hline Before & 0.03 & 0.14 & 0.23 & \multirow{2}{*}{$+14 \%$} \\
\hline After & 0.08 & 0.16 & 0.34 & \\
\hline \multicolumn{5}{|l|}{ Fall } \\
\hline Before & 0.05 & 0.09 & 0.28 & \multirow{2}{*}{$+11 \%$} \\
\hline After & 0.08 & 0.10 & 0.16 & \\
\hline
\end{tabular}

\section{Total Suspended Solids (TSS)}

Table 14: Overall and seasonal TSS (mg/L) data summary on Amazon Creek at Railroad Crossing, before and after 2008

\begin{tabular}{|c|c|c|c|c|}
\hline & Minimum & Geometric Mean & Maximum & $\%$ Change in Mean \\
\hline \multicolumn{5}{|l|}{ All Data } \\
\hline Before & 4.0 & 19.0 & 71.0 & \multirow{2}{*}{$+4 \%$} \\
\hline After & 3.2 & 19.8 & 80.0 & \\
\hline \multicolumn{5}{|l|}{ Winter } \\
\hline Before & 4.0 & 8.4 & 25.0 & \multirow{2}{*}{$+39 \%$} \\
\hline After & 3.2 & 11.7 & 53.0 & \\
\hline \multicolumn{5}{|l|}{ Spring } \\
\hline Before & 5.0 & 18.2 & 29.0 & \multirow{2}{*}{$+15 \%$} \\
\hline After & 4.0 & 21.0 & 46.0 & \\
\hline \multicolumn{5}{|l|}{ Summer } \\
\hline Before & 21.0 & 36.8 & 71.0 & \multirow{2}{*}{$-5 \%$} \\
\hline After & 6.8 & 34.8 & 80.0 & \\
\hline \multicolumn{5}{|l|}{ Fall } \\
\hline Before & 4.0 & 10.0 & 19.0 & \multirow{2}{*}{$-46 \%$} \\
\hline After & 3.4 & 5.4 & 8.0 & \\
\hline
\end{tabular}

\section{Biological Oxygen Demand (BOD)}

Table 15: Overall and seasonal BOD (mg/L) data summary on Amazon Creek at Railroad Crossing, before and after 2008

\begin{tabular}{|c|c|c|c|c|}
\hline 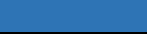 & Minimum & Geometric Mean & Maximum & $\%$ Change in Mean \\
\hline \multicolumn{5}{|l|}{ All Data } \\
\hline Before & 1.0 & 1.6 & 6.0 & \multirow{2}{*}{$+19 \%$} \\
\hline After & 1.0 & 1.9 & 10.0 & \\
\hline \multicolumn{5}{|l|}{ Winter } \\
\hline Before & 1.0 & 1.3 & 2.0 & \multirow{2}{*}{$0 \%$} \\
\hline After & 1.0 & 1.3 & 3.0 & \\
\hline \multicolumn{5}{|l|}{ Spring } \\
\hline Before & 1.0 & 1.5 & 3.0 & \multirow{2}{*}{$+27 \%$} \\
\hline After & 1.0 & 1.9 & 3.0 & \\
\hline \multicolumn{5}{|l|}{ Summer } \\
\hline Before & 1.0 & 2.3 & 6.0 & \multirow{2}{*}{$+17 \%$} \\
\hline After & 1.0 & 2.7 & 10.0 & \\
\hline \multicolumn{5}{|l|}{ Fall } \\
\hline Before & 1.0 & 1.2 & 3.0 & \multirow{2}{*}{$+17 \%$} \\
\hline After & 1.0 & 1.4 & 2.0 & \\
\hline
\end{tabular}

\section{Chemical Oxygen Demand (COD)}

Table 15: Overall and seasonal COD (mg/L) data summary on Amazon Creek at Railroad Crossing, before and after 2008

\begin{tabular}{|c|c|c|c|c|}
\hline & Minimum & Geometric Mean & Maximum & $\%$ Change in Mean \\
\hline \multicolumn{5}{|l|}{ All Data } \\
\hline Before & 5.0 & 14.1 & 41.0 & \multirow{2}{*}{$+31 \%$} \\
\hline After & 2.5 & 18.5 & 46.0 & \\
\hline \multicolumn{5}{|l|}{ Winter } \\
\hline Before & 5.0 & 9.9 & 21.0 & \multirow{2}{*}{$+64 \%$} \\
\hline After & 2.5 & 16.2 & 32.0 & \\
\hline \multicolumn{5}{|l|}{ Spring } \\
\hline Before & 5.0 & 16.1 & 33.0 & $+1 \%$ \\
\hline
\end{tabular}




\begin{tabular}{|c|c|c|c|c|}
\hline After & 5.0 & 16.3 & 30.0 & \\
\hline \multicolumn{5}{|l|}{ Summer } \\
\hline Before & 5.0 & 17.6 & 41.0 & \multirow{2}{*}{$+32 \%$} \\
\hline After & 11.0 & 23.2 & 46.0 & \\
\hline \multicolumn{5}{|l|}{ Fall } \\
\hline Before & 5.0 & 12.6 & 22.0 & \multirow{2}{*}{$+30 \%$} \\
\hline After & 9.0 & 16.4 & 26.0 & \\
\hline
\end{tabular}

\section{Amazon Creek at Royal Avenue}

\section{Ammonia}

Table 16: Overall and seasonal ammonia (mg/L) data summary on Amazon Creek at Royal Avenue, before and after 2008

\begin{tabular}{|c|c|c|c|c|}
\hline & Minimum & Geometric Mean & Maximum & $\%$ Change in Mean \\
\hline \multicolumn{5}{|l|}{ All Data } \\
\hline Before & 0.00 & 0.04 & 0.30 & \multirow{2}{*}{$+75 \%$} \\
\hline After & 0.00 & 0.07 & 0.90 & \\
\hline \multicolumn{5}{|l|}{ Winter } \\
\hline Before & 0.05 & 0.06 & 0.16 & \multirow{2}{*}{$-17 \%$} \\
\hline After & 0.05 & 0.05 & 0.05 & \\
\hline \multicolumn{5}{|l|}{ Spring } \\
\hline Before & 0.05 & 0.05 & 0.05 & \multirow{2}{*}{$+20 \%$} \\
\hline After & 0.05 & 0.06 & 0.10 & \\
\hline \multicolumn{5}{|l|}{ Summer } \\
\hline Before & 0.05 & 0.08 & 0.30 & \multirow{2}{*}{$+50 \%$} \\
\hline After & 0.01 & 0.12 & 0.90 & \\
\hline \multicolumn{5}{|l|}{ Fall } \\
\hline Before & 0.05 & 0.05 & 0.10 & \multirow{2}{*}{$+20 \%$} \\
\hline After & 0.05 & 0.06 & 0.10 & \\
\hline
\end{tabular}

\section{Temperature}

Table 17: Overall and seasonal temperature $\left({ }^{\circ} \mathrm{C}\right)$ data summary on Amazon Creek at Royal Avenue, before and after 2008

\begin{tabular}{|c|c|c|c|c|}
\hline & Minimum & Geometric Mean & Maximum & $\%$ Change in Mean \\
\hline \multicolumn{5}{|l|}{ All Data } \\
\hline Before & 3.4 & 15.4 & 26.7 & \multirow{2}{*}{$-15 \%$} \\
\hline After & 3.6 & 13.1 & 23.4 & \\
\hline \multicolumn{5}{|l|}{ Winter } \\
\hline Before & 3.4 & 10.1 & 13.7 & \multirow{2}{*}{$-28 \%$} \\
\hline After & 3.6 & 7.3 & 10.8 & \\
\hline \multicolumn{5}{|l|}{ Spring } \\
\hline Before & 12.3 & 19.0 & 25.0 & \multirow{2}{*}{$-18 \%$} \\
\hline After & 8.6 & 15.5 & 18.3 & \\
\hline \multicolumn{5}{|l|}{ Summer } \\
\hline Before & 16.0 & 21.5 & 26.7 & \multirow{2}{*}{$-10 \%$} \\
\hline After & 15.0 & 19.4 & 23.4 & \\
\hline \multicolumn{5}{|l|}{ Fall } \\
\hline Before & 6.4 & 10.4 & 19.2 & \multirow{2}{*}{$+1 \%$} \\
\hline After & 6.4 & 10.5 & 19.2 & \\
\hline
\end{tabular}

\section{Nitrate/Nitrite as $\mathbf{N}$}

Table 18: Overall and seasonal Nitrate/Nitrite as N (mg/L) data summary on Amazon creek at Royal Avenue, before and after 2008

\begin{tabular}{|c|c|c|c|c|}
\hline & Minimum & Geometric Mean & Maximum & $\%$ Change in Mean \\
\hline \multicolumn{5}{|l|}{ All Data } \\
\hline Before & 0.03 & 0.22 & 1.40 & \multirow{2}{*}{$-27 \%$} \\
\hline After & 0.03 & 0.28 & 1.00 & \\
\hline \multicolumn{5}{|l|}{ Winter } \\
\hline Before & 0.03 & 0.26 & 0.72 & \multirow{2}{*}{$+27 \%$} \\
\hline After & 0.16 & 0.33 & 0.55 & \\
\hline \multicolumn{5}{|l|}{ Spring } \\
\hline Before & 0.03 & 0.16 & 0.38 & \multirow{2}{*}{$-31 \%$} \\
\hline After & 0.03 & 0.11 & 0.24 & \\
\hline
\end{tabular}




\begin{tabular}{|c|c|c|c|c|}
\hline Before & 0.03 & 0.05 & 0.25 & \multirow{2}{*}{$+200 \%$} \\
\hline After & 0.03 & 0.15 & 0.75 & \\
\hline \multicolumn{5}{|l|}{ Fall } \\
\hline Before & 0.03 & 0.44 & 1.40 & \multirow{2}{*}{$+14 \%$} \\
\hline After & 0.03 & 0.50 & 1.40 & \\
\hline
\end{tabular}

\section{Ortho-phosphorus}

Table 19: Overall and seasonal Ortho-phosphorus (mg/L) data summary on Amazon creek at Royal Avenue, before and after 2008

\begin{tabular}{|c|c|c|c|c|}
\hline & Minimum & Geometric Mean & Maximum & $\%$ Change in Mean \\
\hline \multicolumn{5}{|l|}{ All Data } \\
\hline Before & 0.01 & 0.04 & 0.49 & \multirow{2}{*}{$-25 \%$} \\
\hline After & 0.01 & 0.03 & 0.08 & \\
\hline \multicolumn{5}{|l|}{ Winter } \\
\hline Before & 0.01 & 0.04 & 0.08 & \multirow[b]{2}{*}{$-25 \%$} \\
\hline After & 0.01 & 0.03 & 0.06 & \\
\hline \multicolumn{5}{|l|}{ Spring } \\
\hline Before & 0.01 & 0.03 & 0.08 & \multirow{2}{*}{$-50 \%$} \\
\hline After & 0.01 & 0.02 & 0.03 & \\
\hline \multicolumn{5}{|l|}{ Summer } \\
\hline Before & 0.01 & 0.06 & 0.49 & \multirow{2}{*}{$+300 \%$} \\
\hline After & 0.01 & 0.02 & 0.06 & \\
\hline \multicolumn{5}{|l|}{ Fall } \\
\hline Before & 0.02 & 0.05 & 0.09 & \multirow{2}{*}{$0 \%$} \\
\hline After & 0.02 & 0.05 & 0.09 & \\
\hline
\end{tabular}

\section{Total Phosphorus}

Table 20: Overall and seasonal Total Phosphorus (mg/L) data summary on Amazon Creek at Royal Avenue, before and after 2008

\begin{tabular}{|c|c|c|c|c|}
\hline 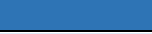 & Minimum & Geometric Mean & Maximum & $\%$ Change in Mean \\
\hline \multicolumn{5}{|l|}{ All Data } \\
\hline Before & 0.02 & 0.12 & 0.78 & \multirow{2}{*}{$-17 \%$} \\
\hline After & 0.03 & 0.10 & 0.47 & \\
\hline \multicolumn{5}{|l|}{ Winter } \\
\hline Before & 0.06 & 0.14 & 0.78 & \multirow{2}{*}{$-36 \%$} \\
\hline After & 0.04 & 0.09 & 0.17 & \\
\hline \multicolumn{5}{|l|}{ Spring } \\
\hline Before & 0.02 & 0.10 & 0.26 & \multirow{2}{*}{$-10 \%$} \\
\hline After & 0.03 & 0.09 & 0.22 & \\
\hline \multicolumn{5}{|l|}{ Summer } \\
\hline Before & 0.02 & 0.12 & 0.36 & \multirow{2}{*}{$+8 \%$} \\
\hline After & 0.04 & 0.13 & 0.47 & \\
\hline \multicolumn{5}{|l|}{ Fall } \\
\hline Before & 0.05 & 0.14 & 0.32 & \multirow{2}{*}{$-7 \%$} \\
\hline After & 0.05 & 0.13 & 0.32 & \\
\hline
\end{tabular}

\section{Total Suspended Solids (TSS)}

Table 21: Overall and seasonal TSS (mg/L) data summary on Amazon Creek at Royal Avenue, before and after 2008

\begin{tabular}{|c|c|c|c|c|}
\hline & Minimum & Geometric Mean & Maximum & $\%$ Change in Mean \\
\hline \multicolumn{5}{|l|}{ All Data } \\
\hline Before & 3.0 & 24.7 & 97.0 & \multirow{2}{*}{$-21 \%$} \\
\hline After & 2.6 & 19.5 & 170.0 & \\
\hline \multicolumn{5}{|l|}{ Winter } \\
\hline Before & 6.0 & 17.2 & 43.0 & \multirow{2}{*}{$-19 \%$} \\
\hline After & 2.6 & 13.9 & 62.0 & \\
\hline \multicolumn{5}{|l|}{ Spring } \\
\hline Before & 5.0 & 26.4 & 89.0 & \multirow{2}{*}{$-49 \%$} \\
\hline After & 3.4 & 13.4 & 33.0 & \\
\hline \multicolumn{5}{|l|}{ Summer } \\
\hline Before & 4.0 & 33.3 & 97.0 & \multirow{2}{*}{$+13 \%$} \\
\hline After & 5.0 & 37.5 & 170.0 & \\
\hline \multicolumn{5}{|l|}{ Fall } \\
\hline Before & 3.0 & 21.1 & 89.0 & \multirow{2}{*}{$-24 \%$} \\
\hline After & 3.0 & 16.0 & 89.0 & \\
\hline
\end{tabular}




\section{Biological Oxygen Demand (BOD)}

Table 22: Overall and seasonal BOD ( $\mathrm{mg} / \mathrm{L}$ ) data summary on Amazon Creek at Royal Avenue, before and after 2008

\begin{tabular}{|c|c|c|c|c|}
\hline & Minimum & Geometric Mean & Maximum & $\%$ Change in Mean \\
\hline \multicolumn{5}{|l|}{ All Data } \\
\hline Before & 1.0 & 1.9 & 7.0 & \multirow{2}{*}{$-11 \%$} \\
\hline After & 1.0 & 1.7 & 6.5 & \\
\hline \multicolumn{5}{|l|}{ Winter } \\
\hline Before & 1.0 & 1.6 & 5.0 & \multirow{2}{*}{$-19 \%$} \\
\hline After & 1.0 & 1.3 & 3.0 & \\
\hline \multicolumn{5}{|l|}{ Spring } \\
\hline Before & 1.0 & 2.1 & 4.0 & \multirow{2}{*}{$-19 \%$} \\
\hline After & 1.0 & 1.7 & 4.0 & \\
\hline \multicolumn{5}{|l|}{ Summer } \\
\hline Before & 1.0 & 2.5 & 7.0 & \multirow{2}{*}{$-4 \%$} \\
\hline After & 1.0 & 2.4 & 6.5 & \\
\hline \multicolumn{5}{|l|}{ Fall } \\
\hline Before & 1.0 & 1.6 & 4.0 & \multirow{2}{*}{$-6 \%$} \\
\hline After & 1.0 & 1.5 & 4.0 & \\
\hline
\end{tabular}

\section{Chemical Oxygen Demand (COD)}

Table 23: Overall and seasonal COD (mg/L) data summary on Amazon Creek at Royal Avenue, before and after 2008

\begin{tabular}{|c|c|c|c|c|}
\hline & Minimum & Geometric Mean & Maximum & $\%$ Change in Mean \\
\hline \multicolumn{5}{|l|}{ All Data } \\
\hline Before & 0.5 & 13.8 & 47.0 & \multirow{2}{*}{$+54 \%$} \\
\hline After & 0.0 & 21.3 & 112.0 & \\
\hline \multicolumn{5}{|l|}{ Winter } \\
\hline Before & 0.5 & 10.9 & 29.0 & \multirow{2}{*}{$+6 \%$} \\
\hline After & 2.5 & 17.2 & 35.0 & \\
\hline \multicolumn{5}{|l|}{ Spring } \\
\hline Before & 0.5 & 19.2 & 36.0 & \multirow{2}{*}{$-4 \%$} \\
\hline After & 0.5 & 15.1 & 33.0 & \\
\hline \multicolumn{5}{|l|}{ Summer } \\
\hline Before & 0.5 & 14.1 & 47.0 & \multirow{2}{*}{$+88 \%$} \\
\hline After & 16.0 & 26.5 & 67.0 & \\
\hline \multicolumn{5}{|l|}{ Fall } \\
\hline Before & 0.5 & 11.9 & 28.0 & \multirow{2}{*}{$+56 \%$} \\
\hline After & 0.5 & 18.6 & 112.0 & \\
\hline
\end{tabular}

\section{Willow Creek at $18^{\text {th }}$ Avenue}

\section{Ammonia}

Table 24: Overall and seasonal ammonia ( $\mathrm{mg} / \mathrm{L})$ data summary on Willow Creek at $18^{\text {th }}$ Avenue, before and after 2008

\begin{tabular}{|c|c|c|c|c|}
\hline & Minimum & Geometric Mean & Maximum & $\%$ Change in Mean \\
\hline \multicolumn{5}{|l|}{ All Data } \\
\hline Before & 0.00 & 0.03 & 0.05 & \multirow{2}{*}{$+67 \%$} \\
\hline After & 0.05 & 0.05 & 0.05 & \\
\hline \multicolumn{5}{|l|}{ Winter } \\
\hline Before & 0.05 & 0.05 & 0.05 & \multirow{2}{*}{$0 \%$} \\
\hline After & 0.05 & 0.05 & 0.05 & \\
\hline \multicolumn{5}{|l|}{ Spring } \\
\hline Before & 0.05 & 0.05 & 0.05 & \multirow{2}{*}{$0 \%$} \\
\hline After & 0.05 & 0.05 & 0.05 & \\
\hline \multicolumn{5}{|l|}{ Summer } \\
\hline Before & 0.05 & 0.05 & 0.05 & \multirow{2}{*}{$0 \%$} \\
\hline After & 0.05 & 0.05 & 0.05 & \\
\hline \multicolumn{5}{|l|}{ Fall } \\
\hline Before & 0.05 & 0.05 & 0.05 & \multirow{2}{*}{$0 \%$} \\
\hline After & 0.05 & 0.05 & 0.05 & \\
\hline
\end{tabular}




\section{Temperature}

Table 25: Overall and seasonal temperature $\left({ }^{\circ} \mathrm{C}\right)$ data summary on Willow Creek at $18^{\text {th }}$ Avenue, before and after 2008

\begin{tabular}{|c|c|c|c|c|}
\hline & Minimum & Geometric Mean & Maximum & $\%$ Change in Mean \\
\hline \multicolumn{5}{|l|}{ All Data } \\
\hline Before & 3.2 & 11.6 & 20.5 & \multirow{2}{*}{$-15 \%$} \\
\hline After & 3.0 & 9.9 & 19.2 & \\
\hline \multicolumn{5}{|l|}{ Winter } \\
\hline Before & 3.2 & 8.2 & 15.3 & \multirow{2}{*}{$-21 \%$} \\
\hline After & 3.0 & 6.5 & 9.5 & \\
\hline \multicolumn{5}{|l|}{ Spring } \\
\hline Before & 10.1 & 14.9 & 20.0 & \multirow{2}{*}{$-11 \%$} \\
\hline After & 7.8 & 13.3 & 16.3 & \\
\hline \multicolumn{5}{|l|}{ Summer } \\
\hline Before & 11.5 & 16.4 & 20.5 & \multirow{2}{*}{$+7 \%$} \\
\hline After & 15.8 & 17.5 & 19.2 & \\
\hline \multicolumn{5}{|l|}{ Fall } \\
\hline Before & 4.6 & 8.6 & 14.6 & \multirow{2}{*}{$+28 \%$} \\
\hline After & 8.5 & 11.0 & 13.2 & \\
\hline
\end{tabular}

\section{Nitrate/Nitrite as $\mathbf{N}$}

Table 26: Overall and seasonal Nitrate/Nitrite as $\mathrm{N}(\mathrm{mg} / \mathrm{L})$ data summary on Willow Creek at $18^{\text {th }}$ Avenue, before and after 2008

\begin{tabular}{|c|c|c|c|c|}
\hline & Minimum & Geometric Mean & Maximum & $\%$ Change in Mean \\
\hline \multicolumn{5}{|l|}{ All Data } \\
\hline Before & 0.03 & 0.08 & 0.63 & \multirow{2}{*}{$-38 \%$} \\
\hline After & 0.03 & 0.05 & 0.39 & \\
\hline \multicolumn{5}{|l|}{ Winter } \\
\hline Before & 0.03 & 0.11 & 0.63 & \multirow{2}{*}{$-55 \%$} \\
\hline After & 0.03 & 0.05 & 0.13 & \\
\hline \multicolumn{5}{|l|}{ Spring } \\
\hline Before & 0.03 & 0.03 & 0.08 & \multirow{2}{*}{$0 \%$} \\
\hline After & 0.03 & 0.03 & 0.03 & \\
\hline \multicolumn{5}{|l|}{ Summer } \\
\hline Before & 0.03 & 0.04 & 0.13 & \multirow{2}{*}{$+500 \%$} \\
\hline After & 0.09 & 0.24 & 0.39 & \\
\hline \multicolumn{5}{|l|}{ Fall } \\
\hline Before & 0.03 & 0.13 & 0.34 & \multirow{2}{*}{ - $77 \%$} \\
\hline After & 0.03 & 0.03 & 0.03 & \\
\hline
\end{tabular}

\section{Ortho-phosphorus}

Table 27: Overall and seasonal Ortho-phosphorus (mg/L) data summary on Willow Creek at $18^{\text {th }}$ Avenue, before and after 2008

\begin{tabular}{|c|c|c|c|c|}
\hline & Minimum & Geometric Mean & Maximum & $\%$ Change in Mean \\
\hline \multicolumn{5}{|l|}{ All Data } \\
\hline Before & 0.01 & 0.04 & 0.49 & \multirow{2}{*}{$-50 \%$} \\
\hline After & 0.01 & 0.02 & 0.06 & \\
\hline \multicolumn{5}{|l|}{ Winter } \\
\hline Before & 0.01 & 0.04 & 0.11 & \multirow{2}{*}{$-50 \%$} \\
\hline After & 0.01 & 0.02 & 0.06 & \\
\hline \multicolumn{5}{|l|}{ Spring } \\
\hline Before & 0.01 & 0.03 & 0.11 & \multirow{2}{*}{$-67 \%$} \\
\hline After & 0.01 & 0.01 & 0.02 & \\
\hline \multicolumn{5}{|l|}{ Summer } \\
\hline Before & 0.01 & 0.03 & 0.12 & \multirow{2}{*}{$0 \%$} \\
\hline After & 0.02 & 0.03 & 0.03 & \\
\hline \multicolumn{5}{|l|}{ Fall } \\
\hline Before & 0.01 & 0.09 & 0.49 & \multirow{2}{*}{$-78 \%$} \\
\hline After & 0.01 & 0.02 & 0.02 & \\
\hline
\end{tabular}

\section{Total Phosphorus}

Table 28: Overall and seasonal Total Phosphorus ( $\mathrm{mg} / \mathrm{L}$ ) data summary on Willow Creek $18^{\text {th }}$ Avenue, before and after 2008 All Data 


\begin{tabular}{|c|c|c|c|c|}
\hline Before & 0.01 & 0.06 & 0.15 & \multirow{2}{*}{$0 \%$} \\
\hline After & 0.02 & 0.06 & 0.15 & \\
\hline \multicolumn{5}{|l|}{ Winter } \\
\hline Before & 0.01 & 0.06 & 0.15 & \multirow{2}{*}{$+17 \%$} \\
\hline After & 0.02 & 0.07 & 0.15 & \\
\hline \multicolumn{5}{|l|}{ Spring } \\
\hline Before & 0.02 & 0.04 & 0.08 & \multirow{2}{*}{$+75 \%$} \\
\hline After & 0.02 & 0.07 & 0.14 & \\
\hline \multicolumn{5}{|l|}{ Summer } \\
\hline Before & 0.04 & 0.07 & 0.12 & \multirow{2}{*}{$-43 \%$} \\
\hline After & 0.03 & 0.04 & 0.04 & \\
\hline \multicolumn{5}{|l|}{ Fall } \\
\hline Before & 0.03 & 0.06 & 0.09 & \multirow{2}{*}{$0 \%$} \\
\hline After & 0.02 & 0.06 & 0.13 & \\
\hline
\end{tabular}

\section{Total Suspended Solids (TSS)}

Table 29: Overall and seasonal TSS (mg/L) data summary on Willow Creek at $18^{\text {th }}$ Avenue, before and after 2008

\begin{tabular}{|c|c|c|c|c|}
\hline 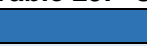 & Minimum & Geometric Mean & Maximum & $\%$ Change in Mean \\
\hline \multicolumn{5}{|l|}{ All Data } \\
\hline Before & 0.5 & 9.4 & 46.0 & \multirow{2}{*}{$-31 \%$} \\
\hline After & 0.5 & 6.5 & 26.0 & \\
\hline \multicolumn{5}{|l|}{ Winter } \\
\hline Before & 0.5 & 4.8 & 12.0 & \multirow{2}{*}{$+63 \%$} \\
\hline After & 0.5 & 7.8 & 26.0 & \\
\hline \multicolumn{5}{|l|}{ Spring } \\
\hline Before & 0.5 & 6.5 & 13.0 & \multirow{2}{*}{$+8 \%$} \\
\hline After & 2.0 & 7.0 & 25.0 & \\
\hline \multicolumn{5}{|l|}{ Summer } \\
\hline Before & 0.5 & 16.8 & 46.0 & \multirow{2}{*}{$-85 \%$} \\
\hline After & 2.0 & 2.6 & 3.2 & \\
\hline \multicolumn{5}{|l|}{ Fall } \\
\hline Before & 0.5 & 9.2 & 29.0 & \multirow{2}{*}{$-60 \%$} \\
\hline After & 0.5 & 3.7 & 9.5 & \\
\hline
\end{tabular}

\section{Biological Oxygen Demand (BOD)}

Table 30: Overall and seasonal BOD (mg/L) data summary on Willow Creek at $18^{\text {th }}$ Avenue, before and after 2008

\begin{tabular}{|c|c|c|c|c|}
\hline 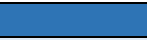 & Minimum & Geometric Mean & Maximum & $\%$ Change in Mean \\
\hline \multicolumn{5}{|l|}{ All Data } \\
\hline Before & 1.0 & 1.5 & 10.0 & \multirow{2}{*}{$-27 \%$} \\
\hline After & 1.0 & 1.1 & 3.0 & \\
\hline \multicolumn{5}{|l|}{ Winter } \\
\hline Before & 1.0 & 1.0 & 1.0 & \multirow[b]{2}{*}{$0 \%$} \\
\hline After & 1.0 & 1.0 & 1.0 & \\
\hline \multicolumn{5}{|l|}{ Spring } \\
\hline Before & 1.0 & 1.1 & 2.0 & \multirow{2}{*}{$+18 \%$} \\
\hline After & 1.0 & 1.3 & 3.0 & \\
\hline \multicolumn{5}{|l|}{ Summer } \\
\hline Before & 1.0 & 2.6 & 10.0 & \multirow{2}{*}{$-62 \%$} \\
\hline After & 1.0 & 1.0 & 1.0 & \\
\hline \multicolumn{5}{|l|}{ Fall } \\
\hline Before & 1.0 & 1.2 & 3.0 & \multirow{2}{*}{$-17 \%$} \\
\hline After & 1.0 & 1.0 & 1.0 & \\
\hline
\end{tabular}

\section{Chemical Oxygen Demand (COD)}

Table 31: Overall and seasonal COD (mg/L) data summary on Willow Creek at $18^{\text {th }}$ Avenue, before and after 2008

\begin{tabular}{|c|c|c|c|c|}
\hline & Minimum & Geometric Mean & Maximum & $\%$ Change in Mean \\
\hline \multicolumn{5}{|l|}{ All Data } \\
\hline Before & 5.0 & 11.8 & 97.0 & \multirow{2}{*}{$+9 \%$} \\
\hline After & 2.5 & 12.9 & 32.0 & \\
\hline \multicolumn{5}{|l|}{ Winter } \\
\hline Before & 5.0 & 6.8 & 16.0 & \multirow{2}{*}{$+109 \%$} \\
\hline After & 2.5 & 14.2 & 32.0 & \\
\hline Spring & & & & \\
\hline
\end{tabular}




\begin{tabular}{|c|c|c|c|c|}
\hline Before & 5.0 & 12.8 & 28.0 & \multirow{2}{*}{$-29 \%$} \\
\hline After & 5.0 & 9.1 & 16.0 & \multirow{2}{*}{$-18 \%$} \\
\hline Summer & 5.0 & 18.8 & 97.0 & 18.0 \\
\hline Before & 13.0 & 15.5 & 19.0 & \multirow{2}{*}{$+64 \%$} \\
\hline After & 5.0 & 8.4 & 29.0 & \\
\hline Fall & 5.0 & 13.8 & & \\
\hline Before & 5.0 &
\end{tabular}

\section{Amazon Diversion Channel at Royal Avenue}

\section{Ammonia}

Table 32: Overall and seasonal ammonia ( $\mathrm{mg} / \mathrm{L}$ ) data summary on Amazon Diversion Channel at Royal Avenue, before and after 2008

\begin{tabular}{|c|c|c|c|c|}
\hline & Minimum & Geometric Mean & Maximum & $\%$ Change in Mean \\
\hline \multicolumn{5}{|l|}{ All Data } \\
\hline Before & 0.1 & 0.1 & 0.30 & \multirow{2}{*}{$0 \%$} \\
\hline After & 0.1 & 0.1 & 0.8 & \\
\hline \multicolumn{5}{|l|}{ Winter } \\
\hline Before & 0.1 & 0.1 & 0.1 & \multirow{2}{*}{$0 \%$} \\
\hline After & 0.1 & 0.1 & 0.1 & \\
\hline \multicolumn{5}{|l|}{ Spring } \\
\hline Before & 0.1 & 0.1 & 0.3 & \multirow{2}{*}{$0 \%$} \\
\hline After & 0.1 & 0.1 & 0.2 & \\
\hline \multicolumn{5}{|l|}{ Summer } \\
\hline Before & 0.1 & 0.1 & 0.2 & \multirow{2}{*}{$0 \%$} \\
\hline After & 0.1 & 0.1 & 0.8 & \\
\hline \multicolumn{5}{|l|}{ Fall } \\
\hline Before & 0.1 & 0.1 & 0.1 & \multirow{2}{*}{$0 \%$} \\
\hline After & 0.1 & 0.1 & 0.1 & \\
\hline
\end{tabular}

\section{Temperature}

Table 33: Overall and seasonal temperature $\left({ }^{\circ} \mathrm{C}\right)$ data summary on Amazon Diversion Channel at Royal Avenue, before and after 2008

\begin{tabular}{|c|c|c|c|c|}
\hline & Minimum & Geometric Mean & Maximum & $\%$ Change in Mean \\
\hline \multicolumn{5}{|l|}{ All Data } \\
\hline Before & 3.2 & 15.7 & 30.5 & \multirow{2}{*}{$-11 \%$} \\
\hline After & 3.9 & 14.0 & 24.2 & \\
\hline \multicolumn{5}{|l|}{ Winter } \\
\hline Before & 3.2 & 10.3 & 17.4 & \multirow{2}{*}{$-20 \%$} \\
\hline After & 3.9 & 8.2 & 12.9 & \\
\hline \multicolumn{5}{|l|}{ Spring } \\
\hline Before & 13.8 & 20.0 & 26.8 & \multirow{2}{*}{$-18 \%$} \\
\hline After & 9.2 & 16.4 & 19.4 & \\
\hline \multicolumn{5}{|l|}{ Summer } \\
\hline Before & 16.4 & 21.6 & 30.5 & \multirow{2}{*}{$-6 \%$} \\
\hline After & 15.1 & 20.2 & 24.2 & \\
\hline \multicolumn{5}{|l|}{ Fall } \\
\hline Before & 5.3 & 10.2 & 17.7 & \multirow{2}{*}{$+6 \%$} \\
\hline After & 6.9 & 10.8 & 14.8 & \\
\hline
\end{tabular}

\section{Nitrate/Nitrite as $\mathbf{N}$}

Table 34: Overall and seasonal Nitrate/Nitrite as N (mg/L) data summary on Amazon Diversion Channel at Royal Avenue, before/after 2008

\begin{tabular}{|l|l|l|l|c|}
\hline & Minimum & Geometric Mean & Maximum & \% Change in Mean \\
\hline All Data & 0.03 & 0.31 & 1.30 & $-13 \%$ \\
\hline Before & 0.03 & 0.27 & 1.20 & - \\
\hline After & 0.03 & \multicolumn{1}{l}{} \\
\hline Winter
\end{tabular}




\begin{tabular}{|c|c|c|c|c|}
\hline Before & 0.03 & 0.46 & 1.2 & \multirow{2}{*}{$+9 \%$} \\
\hline After & 0.06 & 0.50 & 0.99 & \multirow{2}{*}{$-43 \%$} \\
\hline Spring & 0.14 & 0.55 & \multirow{2}{*}{$-6 \%$} \\
\hline Before & 0.03 & 0.19 & \\
\hline After & 0.03 & 0.08 & 0.92 & \multirow{2}{*}{$-48 \%$} \\
\hline Summer & 0.03 & 0.17 & 1.20 & \\
\hline Before & 0.03 & 0.16 & 1.30 & \\
\hline After & 0.03 & 0.28 & \\
\hline Fall Before & 0.03 & 0.44 & 0.23 &
\end{tabular}

\section{Ortho-phosphorus}

Table 35: Overall and seasonal Ortho-phosphorus (mg/L) data summary on Amazon Diversion Channel at Royal Avenue, before/after 2008

\begin{tabular}{|c|c|c|c|c|}
\hline 20 & Minimum & Geometric Mean & Maximum & $\%$ Change in Mean \\
\hline \multicolumn{5}{|l|}{ All Data } \\
\hline Before & 0.01 & 0.06 & 0.51 & \multirow{2}{*}{$-50 \%$} \\
\hline After & 0.01 & 0.03 & 0.09 & \\
\hline \multicolumn{5}{|l|}{ Winter } \\
\hline Before & 0.01 & 0.06 & 0.19 & \multirow{2}{*}{$-50 \%$} \\
\hline After & 0.01 & 0.03 & 0.09 & \\
\hline \multicolumn{5}{|l|}{ Spring } \\
\hline Before & 0.01 & 0.04 & 0.15 & \multirow{2}{*}{$-25 \%$} \\
\hline After & 0.01 & 0.03 & 0.09 & \\
\hline \multicolumn{5}{|l|}{ Summer } \\
\hline Before & 0.02 & 0.06 & 0.17 & \multirow{2}{*}{$-67 \%$} \\
\hline After & 0.01 & 0.02 & 0.09 & \\
\hline \multicolumn{5}{|l|}{ Fall } \\
\hline Before & 0.01 & 0.09 & 0.51 & \multirow{2}{*}{$-44 \%$} \\
\hline After & 0.03 & 0.05 & 0.07 & \\
\hline
\end{tabular}

\section{Total Phosphorus}

Table 36: Overall and seasonal Total Phosphorus (mg/L) data summary on Amazon Diversion Channel at Royal Avenue, before and after 2008

\begin{tabular}{|c|c|c|c|c|}
\hline & Minimum & Geometric Mean & Maximum & $\%$ Change in Mean \\
\hline \multicolumn{5}{|l|}{ All Data } \\
\hline Before & 0.02 & 0.18 & 0.78 & \multirow{2}{*}{$-11 \%$} \\
\hline After & 0.02 & 0.16 & 0.50 & \\
\hline \multicolumn{5}{|l|}{ Winter } \\
\hline Before & 0.05 & 0.15 & 0.25 & \multirow{2}{*}{$-33 \%$} \\
\hline After & 0.02 & 0.10 & 0.15 & \\
\hline \multicolumn{5}{|l|}{ Spring } \\
\hline Before & 0.02 & 0.17 & 0.70 & \multirow{2}{*}{$+24 \%$} \\
\hline After & 0.05 & 0.21 & 0.50 & \\
\hline \multicolumn{5}{|l|}{ Summer } \\
\hline Before & 0.06 & 0.22 & 0.78 & \multirow{2}{*}{$-5 \%$} \\
\hline After & 0.09 & 0.21 & 0.46 & \\
\hline \multicolumn{5}{|l|}{ Fall } \\
\hline Before & 0.03 & 0.18 & 0.28 & \multirow{2}{*}{$-39 \%$} \\
\hline After & 0.06 & 0.11 & 0.14 & \\
\hline
\end{tabular}

\section{Total Suspended Solids (TSS)}

Table 37: Overall and seasonal TSS (mg/L) data summary on Amazon Diversion Channel at Royal Avenue, before and after 2008

\begin{tabular}{|c|c|c|c|c|}
\hline & Minimum & Geometric Mean & Maximum & $\%$ Change in Mean \\
\hline \multicolumn{5}{|l|}{ All Data } \\
\hline Before & 3.0 & 29.4 & 180.0 & \multirow{2}{*}{$+14 \%$} \\
\hline After & 3.0 & 33.5 & 160.0 & \\
\hline \multicolumn{5}{|l|}{ Winter } \\
\hline Before & 4.0 & 17.8 & 42.0 & \multirow{2}{*}{$-46 \%$} \\
\hline After & 3.0 & 9.7 & 23.0 & \\
\hline \multicolumn{5}{|l|}{ Spring } \\
\hline Before & 4.0 & 26.7 & 64.0 & $+113 \%$ \\
\hline
\end{tabular}




\begin{tabular}{|c|c|c|c|c|}
\hline After & 5.0 & 56.8 & 160.0 & \\
\hline \multicolumn{5}{|l|}{ Summer } \\
\hline Before & 3.0 & 41.6 & 180.0 & \multirow{2}{*}{$+37 \%$} \\
\hline After & 7.8 & 56.8 & 110.0 & \\
\hline \multicolumn{5}{|l|}{ Fall } \\
\hline Before & 8.0 & 30.1 & 89.0 & \multirow{2}{*}{$-74 \%$} \\
\hline After & 3.0 & 7.7 & 18.0 & \\
\hline
\end{tabular}

\section{Biological Oxygen Demand (BOD)}

Table 38: Overall and seasonal BOD (mg/L) data summary on Amazon Diversion Channel at Royal Avenue, before and after 2008

\begin{tabular}{|c|c|c|c|c|}
\hline & Minimum & Geometric Mean & Maximum & $\%$ Change in Mean \\
\hline \multicolumn{5}{|l|}{ All Data } \\
\hline Before & 1.0 & 3.0 & 9.0 & \multirow{2}{*}{$-20 \%$} \\
\hline After & 1.0 & 2.4 & 10.0 & \\
\hline \multicolumn{5}{|l|}{ Winter } \\
\hline Before & 1.0 & 1.9 & 4.0 & \multirow{2}{*}{$-32 \%$} \\
\hline After & 1.0 & 1.3 & 3.0 & \\
\hline \multicolumn{5}{|l|}{ Spring } \\
\hline Before & 1.0 & 3.3 & 5.0 & \multirow{2}{*}{$-18 \%$} \\
\hline After & 1.0 & 2.7 & 5.0 & \\
\hline \multicolumn{5}{|l|}{ Summer } \\
\hline Before & 2.0 & 4.4 & 9.0 & \multirow{2}{*}{$-7 \%$} \\
\hline After & 1.0 & 4.1 & 10.0 & \\
\hline \multicolumn{5}{|l|}{ Fall } \\
\hline Before & 1.0 & 2.4 & 5.0 & \multirow{2}{*}{$-46 \%$} \\
\hline After & 1.0 & 1.3 & 2.0 & \\
\hline
\end{tabular}

\section{Chemical Oxygen Demand (COD)}

Table 39: Overall and seasonal COD (mg/L) data summary on Amazon Diversion Channel at Royal Avenue, before and after 2008

\begin{tabular}{|c|c|c|c|c|}
\hline 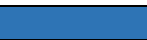 & Minimum & Geometric Mean & Maximum & $\%$ Change in Mean \\
\hline \multicolumn{5}{|l|}{ All Data } \\
\hline Before & 5.0 & 22.9 & 83.0 & \multirow{2}{*}{$+4 \%$} \\
\hline After & 2.5 & 23.9 & 48.0 & \\
\hline \multicolumn{5}{|l|}{ Winter } \\
\hline Before & 5.0 & 16.9 & 30.0 & \multirow{2}{*}{$+9 \%$} \\
\hline After & 2.5 & 18.4 & 48.0 & \\
\hline \multicolumn{5}{|l|}{ Spring } \\
\hline Before & 5.0 & 26.0 & 83.0 & \multirow{2}{*}{$-11 \%$} \\
\hline After & 11.0 & 23.2 & 32.0 & \\
\hline \multicolumn{5}{|l|}{ Summer } \\
\hline Before & 5.0 & 30.6 & 68.0 & \multirow{2}{*}{$+6 \%$} \\
\hline After & 18.0 & 32.4 & 47.0 & \\
\hline \multicolumn{5}{|l|}{ Fall } \\
\hline Before & 5.0 & 16.8 & 33.0 & \multirow{2}{*}{$+17 \%$} \\
\hline After & 16.0 & 19.6 & 24.0 & \\
\hline
\end{tabular}

\section{A-3 Drain at Terry Street}

\section{Ammonia}

Table 40: Overall and seasonal ammonia $(\mathrm{mg} / \mathrm{L})$ data summary on A-3 Drain at Terry Street, before and after 2008

\begin{tabular}{|c|c|c|c|c|}
\hline & Minimum & Geometric Mean & Maximum & $\%$ Change in Mean \\
\hline \multicolumn{5}{|l|}{ All Data } \\
\hline Before & 0.00 & 0.13 & 1.70 & \multirow{2}{*}{$-24 \%$} \\
\hline After & 0.05 & 0.10 & 0.80 & \\
\hline \multicolumn{5}{|l|}{ Winter } \\
\hline Before & 0.05 & 0.18 & 0.50 & \multirow{2}{*}{$-50 \%$} \\
\hline After & 0.05 & 0.09 & 0.40 & \\
\hline \multicolumn{5}{|l|}{ Spring } \\
\hline Before & 0.05 & 0.07 & 0.20 & \multirow{2}{*}{$-1 \%$} \\
\hline After & 0.05 & 0.06 & 0.10 & \\
\hline
\end{tabular}




\begin{tabular}{|c|c|c|c|c|}
\hline \multicolumn{5}{|l|}{ Summer } \\
\hline Before & 0.05 & 0.07 & 0.20 & \multirow{2}{*}{$+114 \%$} \\
\hline After & 0.05 & 0.15 & 0.80 & \\
\hline \multicolumn{5}{|l|}{ Fall } \\
\hline Before & 0.05 & 0.25 & 1.70 & \multirow{2}{*}{$-60 \%$} \\
\hline After & 0.05 & 0.10 & 0.20 & \\
\hline
\end{tabular}

\section{Temperature}

Table 41: Overall and seasonal temperature $\left({ }^{\circ} \mathrm{C}\right)$ data summary on A-3 Drain at Terry Street, before and after 2008

\begin{tabular}{|c|c|c|c|c|}
\hline & Minimum & Geometric Mean & Maximum & $\%$ Change in Mean \\
\hline \multicolumn{5}{|l|}{ All Data } \\
\hline Before & 4.8 & 16.2 & 27.9 & \multirow{2}{*}{$-23 \%$} \\
\hline After & 4.1 & 12.7 & 20.4 & \\
\hline \multicolumn{5}{|l|}{ Winter } \\
\hline Before & 4.8 & 10.7 & 14.0 & \multirow{2}{*}{$-23 \%$} \\
\hline After & 4.1 & 8.2 & 12.0 & \\
\hline \multicolumn{5}{|l|}{ Spring } \\
\hline Before & 14.2 & 20.5 & 27.9 & \multirow{2}{*}{$-22 \%$} \\
\hline After & 9.1 & 15.9 & 18.8 & \\
\hline \multicolumn{5}{|l|}{ Summer } \\
\hline Before & 16.1 & 22.5 & 27.4 & \multirow{2}{*}{$-17 \%$} \\
\hline After & 15.0 & 18.7 & 20.4 & \\
\hline \multicolumn{5}{|l|}{ Fall } \\
\hline Before & 6.6 & 10.4 & 17.1 & \multirow{2}{*}{$+60 \%$} \\
\hline After & 7.1 & 16.6 & 14.0 & \\
\hline
\end{tabular}

\section{Nitrate/Nitrite as $\mathbf{N}$}

Table 42: Overall and seasonal Nitrate/Nitrite as N (mg/L) data summary on A-3 Drain at Terry Street, before and after 2008

\begin{tabular}{|c|c|c|c|c|}
\hline & Minimum & Geometric Mean & Maximum & $\%$ Change in Mean \\
\hline \multicolumn{5}{|l|}{ All Data } \\
\hline Before & 0.03 & 0.51 & 8.00 & \multirow{2}{*}{$-16 \%$} \\
\hline After & 0.03 & 0.43 & 1.40 & \\
\hline \multicolumn{5}{|l|}{ Winter } \\
\hline Before & 0.20 & 0.52 & 1.00 & \multirow{2}{*}{$+29 \%$} \\
\hline After & 0.27 & 0.67 & 1.40 & \\
\hline \multicolumn{5}{|l|}{ Spring } \\
\hline Before & 0.06 & 0.99 & 8.00 & \multirow{2}{*}{$-78 \%$} \\
\hline After & 0.03 & 0.22 & 0.66 & \\
\hline \multicolumn{5}{|l|}{ Summer } \\
\hline Before & 0.03 & 0.07 & 0.19 & \multirow{2}{*}{$+114 \%$} \\
\hline After & 0.03 & 0.15 & 0.55 & \\
\hline \multicolumn{5}{|l|}{ Fall } \\
\hline Before & 0.18 & 0.57 & 0.88 & \multirow{2}{*}{$-9 \%$} \\
\hline After & 0.13 & 0.52 & 1.00 & \\
\hline
\end{tabular}

\section{Ortho-phosphorus}

Table 43: Overall and seasonal Ortho-phosphorus (mg/L) data summary on A-3 Drain at Terry Street, before and after 2008

\begin{tabular}{|c|c|c|c|c|}
\hline & Minimum & Geometric Mean & Maximum & $\%$ Change in Mean \\
\hline \multicolumn{5}{|l|}{ All Data } \\
\hline Before & 0.01 & 0.06 & 0.25 & \multirow{2}{*}{$-33 \%$} \\
\hline After & 0.01 & 0.04 & 0.11 & \\
\hline \multicolumn{5}{|l|}{ Winter } \\
\hline Before & 0.01 & 0.05 & 0.12 & \multirow{2}{*}{$-40 \%$} \\
\hline After & 0.01 & 0.03 & 0.11 & \\
\hline \multicolumn{5}{|l|}{ Spring } \\
\hline Before & 0.01 & 0.06 & 0.16 & \multirow{2}{*}{$-17 \%$} \\
\hline After & 0.02 & 0.05 & 0.11 & \\
\hline \multicolumn{5}{|l|}{ Summer } \\
\hline Before & 0.04 & 0.10 & 0.25 & \multirow{2}{*}{$-40 \%$} \\
\hline After & 0.04 & 0.06 & 0.08 & \\
\hline \multicolumn{5}{|l|}{ Fall } \\
\hline Before & 0.02 & 0.05 & 0.08 & $0 \%$ \\
\hline
\end{tabular}




\section{Total Phosphorus}

Table 44: Overall and seasonal Total Phosphorus (mg/L) data summary on A-3 Drain at Terry Street, before and after 2008

\begin{tabular}{|c|c|c|c|c|}
\hline & Minimum & Geometric Mean & Maximum & $\%$ Change in Mean \\
\hline \multicolumn{5}{|l|}{ All Data } \\
\hline Before & 0.08 & 0.25 & 0.64 & \multirow{2}{*}{$-32 \%$} \\
\hline After & 0.06 & 0.17 & 0.42 & \\
\hline \multicolumn{5}{|l|}{ Winter } \\
\hline Before & 0.09 & 0.18 & 0.31 & \multirow{2}{*}{$-28 \%$} \\
\hline After & 0.06 & 0.13 & 0.34 & \\
\hline \multicolumn{5}{|l|}{ Spring } \\
\hline Before & 0.08 & 0.20 & 0.40 & \multirow{2}{*}{$-10 \%$} \\
\hline After & 0.07 & 0.18 & 0.42 & \\
\hline \multicolumn{5}{|l|}{ Summer } \\
\hline Before & 0.12 & 0.35 & 0.64 & \multirow{2}{*}{$-40 \%$} \\
\hline After & 0.12 & 0.21 & 0.35 & \\
\hline \multicolumn{5}{|l|}{ Fall } \\
\hline Before & 0.16 & 0.25 & 0.35 & \multirow{2}{*}{$-36 \%$} \\
\hline After & 0.10 & 0.16 & 0.21 & \\
\hline
\end{tabular}

\section{Total Suspended Solids (TSS)}

Table 45: Overall and seasonal TSS (mg/L) data summary on A-3 Drain at Terry Street, before and after 2008

\begin{tabular}{|c|c|c|c|c|}
\hline 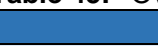 & Minimum & Geometric Mean & Maximum & $\%$ Change in Mean \\
\hline \multicolumn{5}{|l|}{ All Data } \\
\hline Before & 5.0 & 31.9 & 280.0 & \multirow{2}{*}{$-47 \%$} \\
\hline After & 4.0 & 16.8 & 40.0 & \\
\hline \multicolumn{5}{|l|}{ Winter } \\
\hline Before & 7.0 & 18.1 & 65.0 & \multirow{2}{*}{$-14 \%$} \\
\hline After & 4.0 & 15.6 & 40.0 & \\
\hline \multicolumn{5}{|l|}{ Spring } \\
\hline Before & 11.0 & 21.9 & 60.0 & \multirow{2}{*}{$-22 \%$} \\
\hline After & 4.0 & 17.1 & 33.0 & \\
\hline \multicolumn{5}{|l|}{ Summer } \\
\hline Before & 5.0 & 51.2 & 280.0 & \multirow{2}{*}{$-61 \%$} \\
\hline After & 4.0 & 20.1 & 38.0 & \\
\hline \multicolumn{5}{|l|}{ Fall } \\
\hline Before & 7.0 & 33.2 & 71.0 & \multirow{2}{*}{$-56 \%$} \\
\hline After & 4.0 & 14.7 & 28.0 & \\
\hline
\end{tabular}

\section{Biological Oxygen Demand (BOD)}

Table 46: Overall and seasonal BOD (mg/L) data summary on A-3 Drain at Terry Street, before and after 2008

\begin{tabular}{|c|c|c|c|c|}
\hline 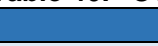 & Minimum & Geometric Mean & Maximum & $\%$ Change in Mean \\
\hline \multicolumn{5}{|l|}{ All Data } \\
\hline Before & 1.0 & 3.4 & 12.0 & \multirow{2}{*}{$-35 \%$} \\
\hline After & 1.0 & 2.2 & 8.0 & \\
\hline \multicolumn{5}{|l|}{ Winter } \\
\hline Before & 1.0 & 2.2 & 4.0 & \multirow{2}{*}{$-23 \%$} \\
\hline After & 1.0 & 1.7 & 4.0 & \\
\hline \multicolumn{5}{|l|}{ Spring } \\
\hline Before & 1.0 & 3.0 & 5.0 & \multirow{2}{*}{$-10 \%$} \\
\hline After & 1.0 & 2.7 & 4.0 & \\
\hline \multicolumn{5}{|l|}{ Summer } \\
\hline Before & 3.0 & 5.8 & 12.0 & \multirow{2}{*}{$-47 \%$} \\
\hline After & 1.0 & 3.1 & 8.0 & \\
\hline \multicolumn{5}{|l|}{ Fall } \\
\hline Before & 1.0 & 2.4 & 5.0 & \multirow{2}{*}{$-33 \%$} \\
\hline After & 1.0 & 1.6 & 3.0 & \\
\hline
\end{tabular}

\section{Chemical Oxygen Demand (COD)}

Table 47: Overall and seasonal COD (mg/L) data summary on A-3 Drain at Terry Street, before and after 2008 


\begin{tabular}{|c|c|c|c|c|}
\hline & Minimum & Geometric Mean & Maximum & $\%$ Change in Mean \\
\hline \multicolumn{5}{|l|}{ All Data } \\
\hline Before & 0.5 & 24.6 & 77.0 & \multirow{2}{*}{$-9 \%$} \\
\hline After & 0.5 & 22.5 & 44.0 & \\
\hline \multicolumn{5}{|l|}{ Winter } \\
\hline Before & 0.5 & 13.9 & 22.0 & \multirow{2}{*}{$+29 \%$} \\
\hline After & 8.0 & 18.0 & 31.0 & \\
\hline \multicolumn{5}{|l|}{ Spring } \\
\hline Before & 0.5 & 22.0 & 42.0 & \multirow{2}{*}{$-4 \%$} \\
\hline After & 0.5 & 21.1 & 36.0 & \\
\hline \multicolumn{5}{|l|}{ Summer } \\
\hline Before & 0.5 & 40.0 & 77.0 & \multirow{2}{*}{$-25 \%$} \\
\hline After & 23.0 & 30.1 & 44.0 & \\
\hline \multicolumn{5}{|l|}{ Fall } \\
\hline Before & 0.5 & 20.1 & 30.0 & \multirow{2}{*}{$+20 \%$} \\
\hline After & 19.0 & 24.1 & 28.0 & \\
\hline
\end{tabular}

\section{Amazon Creek at RM 5.82}

(No before or after data to compare)

\section{Amazon Creek at High Pass Road}

\section{Ammonia}

(No before and after data to compare)

\section{Temperature}

Table 48: Overall and seasonal temperature $\left({ }^{\circ} \mathrm{C}\right)$ data summary on Amazon Creek at High Pass Road, before and after 2008

\begin{tabular}{|c|c|c|c|c|}
\hline & Minimum & Geometric Mean & Maximum & $\%$ Change in Mean \\
\hline \multicolumn{5}{|l|}{ All Data } \\
\hline Before & 3.2 & 13.0 & 22.8 & \multirow{2}{*}{$-2 \%$} \\
\hline After & 0.0 & 12.8 & 21.1 & \\
\hline \multicolumn{5}{|l|}{ Winter } \\
\hline Before & 3.2 & 7.7 & 11.9 & \multirow{2}{*}{$-9 \%$} \\
\hline After & 3.4 & 7.0 & 10.2 & \\
\hline \multicolumn{5}{|l|}{ Spring } \\
\hline Before & \multirow{2}{*}{\multicolumn{4}{|c|}{$\mathrm{N} / \mathrm{A}$}} \\
\hline After & & & & \\
\hline \multicolumn{5}{|l|}{ Summer } \\
\hline Before & 7.5 & 19.2 & 22.8 & \multirow{2}{*}{$-3 \%$} \\
\hline After & 14.5 & 18.7 & 21.1 & \\
\hline \multicolumn{5}{|l|}{ Fall } \\
\hline Before & \multirow{2}{*}{\multicolumn{4}{|c|}{$N / A$}} \\
\hline After & & & & \\
\hline
\end{tabular}

\section{Nitrate/Nitrite as $\mathbf{N}$}

(No before and after data to compare)

\section{Ortho-phosphorus}

(No before and after data to compare)

\section{Total Phosphorus}

Table 49: Overall and seasonal Total Phosphorus (mg/L) data summary on Amazon Creek at High Pass Road, before and after 2008 


\begin{tabular}{|c|c|c|c|c|}
\hline All Data & & & & \\
\hline Before & 0.1 & 0.2 & 0.3 & \multirow[b]{2}{*}{$0 \%$} \\
\hline After & 0.1 & 0.2 & 0.4 & \\
\hline \multicolumn{5}{|l|}{ Winter } \\
\hline Before & 0.1 & 0.2 & 0.3 & \multirow{2}{*}{$-50 \%$} \\
\hline After & 0.1 & 0.1 & 0.3 & \\
\hline \multicolumn{5}{|l|}{ Spring } \\
\hline Before & 0.2 & 0.3 & 0.3 & \multirow{2}{*}{$-33 \%$} \\
\hline After & 0.1 & 0.2 & 0.3 & \\
\hline \multicolumn{5}{|l|}{ Summer } \\
\hline Before & 0.2 & 0.2 & 0.3 & \multirow{2}{*}{$0 \%$} \\
\hline After & 0.1 & 0.2 & 0.4 & \\
\hline \multicolumn{5}{|l|}{ Fall } \\
\hline Before & 0.1 & 0.2 & 0.3 & \multirow{2}{*}{$0 \%$} \\
\hline After & 0.1 & 0.2 & 0.4 & \\
\hline
\end{tabular}

\section{Total Suspended Solids (TSS)}

(No before and after data to compare)

\section{Biological Oxygen Demand (BOD)}

(No before and after data to compare)

\section{Chemical Oxygen Demand (COD)}

(No before and after data to compare)

\section{Coyote Creek at Hamm Road}

\section{Ammonia}

(No before and after data to compare)

\section{Temperature}

Table 50: Overall and seasonal temperature $\left({ }^{\circ} \mathrm{C}\right)$ data summary on Coyote Creek at Hamm Road, before and after 2008

\begin{tabular}{|c|c|c|c|c|}
\hline & Minimum & Geometric Mean & Maximum & $\%$ Change in Mean \\
\hline \multicolumn{5}{|l|}{ All Data } \\
\hline Before & \multirow{2}{*}{\multicolumn{4}{|c|}{$\mathrm{N} / \mathrm{A}$}} \\
\hline After & & & & \\
\hline \multicolumn{5}{|l|}{ Winter } \\
\hline Before & \multirow{2}{*}{\multicolumn{4}{|c|}{$\mathrm{N} / \mathrm{A}$}} \\
\hline After & & & & \\
\hline \multicolumn{5}{|l|}{ Spring } \\
\hline Before & \multirow{2}{*}{\multicolumn{4}{|c|}{$\mathrm{N} / \mathrm{A}$}} \\
\hline After & & & & \\
\hline \multicolumn{5}{|l|}{ Summer } \\
\hline Before & 12.4 & 13.6 & 14.7 & \multirow{2}{*}{$-6 \%$} \\
\hline After & 10.7 & 12.8 & 16.2 & \\
\hline \multicolumn{5}{|l|}{ Fall } \\
\hline Before & \multirow{2}{*}{\multicolumn{4}{|c|}{$\mathrm{N} / \mathrm{A}$}} \\
\hline After & & & & \\
\hline
\end{tabular}

\section{Nitrate/Nitrite as $\mathbf{N}$}

(No before and after data to compare)

\section{Ortho-phosphorus}


Table 51: Overall and seasonal Ortho-phosphorus (mg/L) data summary on Coyote Creek at Hamm Road, before and after 2008

\begin{tabular}{|c|c|c|c|c|}
\hline & Minimum & Geometric Mean & Maximum & $\%$ Change in Mean \\
\hline \multicolumn{5}{|l|}{ All Data } \\
\hline Before & \multirow{2}{*}{\multicolumn{4}{|c|}{$\mathrm{N} / \mathrm{A}$}} \\
\hline After & & & & \\
\hline \multicolumn{5}{|l|}{ Winter } \\
\hline Before & \multirow{2}{*}{\multicolumn{4}{|c|}{$\mathrm{N} / \mathrm{A}$}} \\
\hline After & & & & \\
\hline \multicolumn{5}{|l|}{ Spring } \\
\hline Before & \multirow{2}{*}{\multicolumn{4}{|c|}{$\mathrm{N} / \mathrm{A}$}} \\
\hline After & & & & \\
\hline \multicolumn{5}{|l|}{ Summer } \\
\hline Before & 0.03 & 0.04 & 0.05 & \multirow{2}{*}{$-50 \%$} \\
\hline After & 0.02 & 0.02 & 0.02 & \\
\hline \multicolumn{5}{|l|}{ Fall } \\
\hline Before & \multirow{2}{*}{\multicolumn{4}{|c|}{$N / A$}} \\
\hline After & & & & \\
\hline
\end{tabular}

\section{Total Phosphorus}

Table 52: Overall and seasonal Total Phosphorus (mg/L) data summary on Coyote Creek at Hamm Road, before and after 2008

\begin{tabular}{|c|c|c|c|c|}
\hline 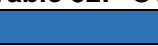 & Minimum & Geometric Mean & Maximum & $\%$ Change in Mean \\
\hline \multicolumn{5}{|l|}{ All Data } \\
\hline Before & \multirow{2}{*}{\multicolumn{4}{|c|}{$\mathrm{N} / \mathrm{A}$}} \\
\hline After & & & & \\
\hline \multicolumn{5}{|l|}{ Winter } \\
\hline Before & \multirow{2}{*}{\multicolumn{4}{|c|}{$\mathrm{N} / \mathrm{A}$}} \\
\hline After & & & & \\
\hline \multicolumn{5}{|l|}{ Spring } \\
\hline Before & \multirow{2}{*}{\multicolumn{4}{|c|}{$\mathrm{N} / \mathrm{A}$}} \\
\hline After & & & & \\
\hline \multicolumn{5}{|l|}{ Summer } \\
\hline Before & 0.04 & 0.05 & 0.06 & \multirow{2}{*}{$0 \%$} \\
\hline After & 0.05 & 0.05 & 0.05 & \\
\hline \multicolumn{5}{|l|}{ Fall } \\
\hline Before & \multirow{2}{*}{\multicolumn{4}{|c|}{$\mathrm{N} / \mathrm{A}$}} \\
\hline After & & & & \\
\hline
\end{tabular}

\section{Total Suspended Solids (TSS)}

(No before and after data to compare)

\section{Biological Oxygen Demand (BOD)}

(No before and after data to compare)

\section{Chemical Oxygen Demand (COD)}

(No before and after data to compare)

\section{Coyote Creek at Powell Road}

\section{Ammonia}

Table 53: Overall and seasonal ammonia (mg/L) data summary on Coyote Creek at Powell Road, before and after 2008

\begin{tabular}{|c|c|c|c|c|}
\hline & Minimum & Geometric Mean & Maximum & $\%$ Change in Mean \\
\hline \multicolumn{5}{|l|}{ All Data } \\
\hline Before & \multirow{2}{*}{\multicolumn{4}{|c|}{$\mathrm{N} / \mathrm{A}$}} \\
\hline After & & & & \\
\hline \multicolumn{5}{|l|}{ Winter } \\
\hline Before & & & $\mathrm{N} / \mathrm{A}$ & \\
\hline
\end{tabular}




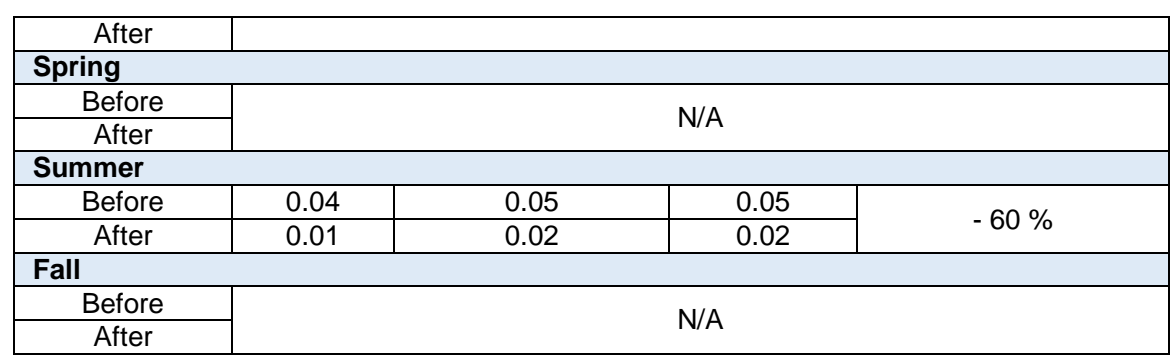

\section{Temperature}

Table 54: Overall and seasonal temperature $\left({ }^{\circ} \mathrm{C}\right)$ data summary on Coyote Creek at Powell road, before and after 2008

\begin{tabular}{|c|c|c|c|c|}
\hline 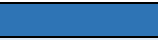 & Minimum & Geometric Mean & Maximum & $\%$ Change in Mean \\
\hline \multicolumn{5}{|l|}{ All Data } \\
\hline Before & \multirow{2}{*}{\multicolumn{4}{|c|}{$N / A$}} \\
\hline After & & & & \\
\hline \multicolumn{5}{|l|}{ Winter } \\
\hline Before & \multirow{2}{*}{\multicolumn{4}{|c|}{$N / A$}} \\
\hline After & & & & \\
\hline \multicolumn{5}{|l|}{ Spring } \\
\hline Before & \multirow{2}{*}{\multicolumn{4}{|c|}{$N / A$}} \\
\hline After & & & & \\
\hline \multicolumn{5}{|l|}{ Summer } \\
\hline Before & 12.8 & 17.1 & 22.4 & \multirow{2}{*}{$-14 \%$} \\
\hline After & 11.9 & 14.7 & 18.2 & \\
\hline \multicolumn{5}{|l|}{ Fall } \\
\hline Before & \multirow{2}{*}{\multicolumn{4}{|c|}{$N / A$}} \\
\hline After & & & & \\
\hline
\end{tabular}

\section{Nitrate/Nitrite as $\mathbf{N}$}

Table 55: Overall and seasonal Nitrate/Nitrite as N (mg/L) data summary on Coyote Creek at Powell Road, before and after 2008

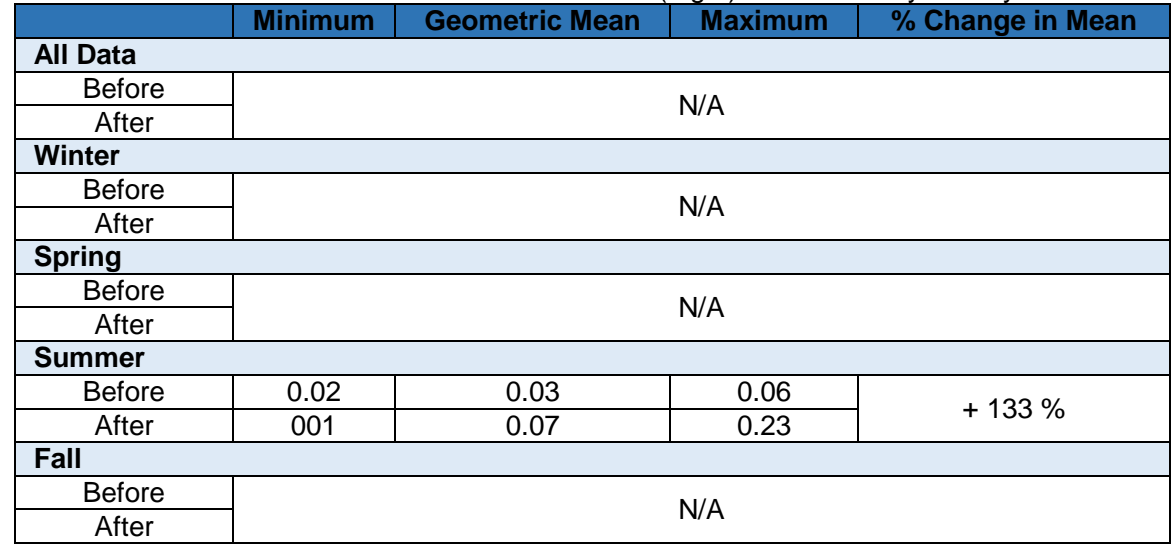

\section{Ortho-phosphorus}

Table 56: Overall and seasonal Ortho-phosphorus (mg/L) data summary on Coyote Creek at Powell Road, before and after 2008

\begin{tabular}{|c|c|c|c|c|}
\hline 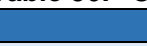 & Minimum & Geometric Mean & Maximum & $\%$ Change in Mean \\
\hline \multicolumn{5}{|l|}{ All Data } \\
\hline Before & & & \multirow{2}{*}{\multicolumn{2}{|c|}{$N / A$}} \\
\hline After & & & & \\
\hline \multicolumn{5}{|l|}{ Winter } \\
\hline Before & & & \multirow{2}{*}{\multicolumn{2}{|c|}{$\mathrm{N} / \mathrm{A}$}} \\
\hline After & & & & \\
\hline \multicolumn{5}{|l|}{ Spring } \\
\hline Before & \multirow{2}{*}{\multicolumn{4}{|c|}{$\mathrm{N} / \mathrm{A}$}} \\
\hline After & & & & \\
\hline \multicolumn{5}{|l|}{ Summer } \\
\hline Before & 0.02 & 0.02 & 0.04 & $0 \%$ \\
\hline
\end{tabular}




\begin{tabular}{|l|l|l|l|l|}
\hline After & 0.02 & 0.02 & 0.03 & \\
\cline { 1 - 1 } Fall & \multicolumn{3}{|c|}{ N/A } \\
\cline { 1 - 1 } Before & \multicolumn{2}{|c|}{ Nfter } &
\end{tabular}

\section{Total Phosphorus}

Table 57: Overall and seasonal Total Phosphorus (mg/L) data summary on Coyote Creek at Powell Road, before and after 2008

\begin{tabular}{|c|c|c|c|c|}
\hline 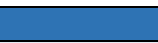 & Minimum & Geometric Mean & Maximum & $\%$ Change in Mean \\
\hline \multicolumn{5}{|l|}{ All Data } \\
\hline Before & \multirow{2}{*}{\multicolumn{4}{|c|}{$\mathrm{N} / \mathrm{A}$}} \\
\hline After & & & & \\
\hline \multicolumn{5}{|l|}{ Winter } \\
\hline Before & \multirow{2}{*}{\multicolumn{4}{|c|}{$\mathrm{N} / \mathrm{A}$}} \\
\hline After & & & & \\
\hline \multicolumn{5}{|l|}{ Spring } \\
\hline Before & \multirow{2}{*}{\multicolumn{4}{|c|}{$\mathrm{N} / \mathrm{A}$}} \\
\hline After & & & & \\
\hline \multicolumn{5}{|l|}{ Summer } \\
\hline Before & 0.02 & 0.04 & 0.06 & \multirow{2}{*}{$+75 \%$} \\
\hline After & 0.06 & 0.07 & 0.09 & \\
\hline \multicolumn{5}{|l|}{ Fall } \\
\hline Before & \multirow{2}{*}{\multicolumn{4}{|c|}{$\mathrm{N} / \mathrm{A}$}} \\
\hline After & & & & \\
\hline
\end{tabular}

\section{Total Suspended Solids (TSS)}

(No before and after data to compare)

\section{Biological Oxygen Demand (BOD)}

(No before and after data to compare)

\section{Chemical Oxygen Demand (COD)}

(No before and after data to compare)

\section{Coyote Creek at Petzold Road}

\section{Ammonia}

(No before and after data to compare)

\section{Temperature}

Table 58: Overall and seasonal temperature $\left({ }^{\circ} \mathrm{C}\right)$ data summary on Coyote Creek at Petzold Road, before and after 2008

\begin{tabular}{|c|c|c|c|c|}
\hline & Minimum & Geometric Mean & Maximum & $\%$ Change in Mean \\
\hline \multicolumn{5}{|l|}{ All Data } \\
\hline Before & \multirow{2}{*}{\multicolumn{4}{|c|}{$\mathrm{N} / \mathrm{A}$}} \\
\hline After & & & & \\
\hline \multicolumn{5}{|l|}{ Winter } \\
\hline Before & \multirow{2}{*}{\multicolumn{4}{|c|}{$\mathrm{N} / \mathrm{A}$}} \\
\hline After & & & & \\
\hline \multicolumn{5}{|l|}{ Spring } \\
\hline Before & \multirow{2}{*}{\multicolumn{4}{|c|}{$\mathrm{N} / \mathrm{A}$}} \\
\hline After & & & & \\
\hline \multicolumn{5}{|l|}{ Summer } \\
\hline Before & 15.0 & 18.5 & 20.6 & \multirow{2}{*}{$-24 \%$} \\
\hline After & 12.3 & 14.0 & 16.1 & \\
\hline \multicolumn{5}{|l|}{ Fall } \\
\hline Before & & & $\mathrm{N} / \mathrm{A}$ & \\
\hline
\end{tabular}


After

\section{Nitrate/Nitrite as $\mathbf{N}$}

Table 59: Overall and seasonal Nitrate/Nitrite as N (mg/L) data summary on Coyote Creek at Petzold Road, before and after 2008

\begin{tabular}{|c|c|c|c|c|}
\hline 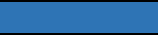 & Minimum & Geometric Mean & Maximum & $\%$ Change in Mean \\
\hline \multicolumn{5}{|l|}{ All Data } \\
\hline Before & \multirow{2}{*}{\multicolumn{4}{|c|}{$\mathrm{N} / \mathrm{A}$}} \\
\hline After & & & & \\
\hline \multicolumn{5}{|l|}{ Winter } \\
\hline Before & \multirow{2}{*}{\multicolumn{4}{|c|}{$\mathrm{N} / \mathrm{A}$}} \\
\hline After & & & & \\
\hline \multicolumn{5}{|l|}{ Spring } \\
\hline Before & \multirow{2}{*}{\multicolumn{4}{|c|}{$\mathrm{N} / \mathrm{A}$}} \\
\hline After & & & & \\
\hline \multicolumn{5}{|l|}{ Summer } \\
\hline Before & 0.02 & 0.04 & 0.08 & \multirow{2}{*}{$-50 \%$} \\
\hline After & 0.01 & 0.02 & 0.03 & \\
\hline \multicolumn{5}{|l|}{ Fall } \\
\hline Before & \multirow{2}{*}{\multicolumn{4}{|c|}{$\mathrm{N} / \mathrm{A}$}} \\
\hline After & & & & \\
\hline
\end{tabular}

\section{Ortho-phosphorus}

Table 60: Overall and seasonal Ortho-phosphorus (mg/L) data summary on Coyote Creek at Petzold Road, before and after 2008

\begin{tabular}{|c|c|c|c|c|}
\hline & Minimum & Geometric Mean & Maximum & $\%$ Change in Mean \\
\hline \multicolumn{5}{|l|}{ All Data } \\
\hline Before & \multirow{2}{*}{\multicolumn{4}{|c|}{$\mathrm{N} / \mathrm{A}$}} \\
\hline After & & & & \\
\hline \multicolumn{5}{|l|}{ Winter } \\
\hline Before & \multirow{2}{*}{\multicolumn{4}{|c|}{$\mathrm{N} / \mathrm{A}$}} \\
\hline After & & & & \\
\hline \multicolumn{5}{|l|}{ Spring } \\
\hline Before & \multirow{2}{*}{\multicolumn{4}{|c|}{$\mathrm{N} / \mathrm{A}$}} \\
\hline After & & & & \\
\hline \multicolumn{5}{|l|}{ Summer } \\
\hline Before & 0.02 & 0.02 & 0.02 & \multirow{2}{*}{$-50 \%$} \\
\hline After & 0.01 & 0.01 & 0.01 & \\
\hline \multicolumn{5}{|l|}{ Fall } \\
\hline Before & \multirow{2}{*}{\multicolumn{4}{|c|}{$\mathrm{N} / \mathrm{A}$}} \\
\hline After & & & & \\
\hline
\end{tabular}

\section{Total Phosphorus}

Table 61: Overall and seasonal Total Phosphorus (mg/L) data summary on Coyote Creek at Petzold Road, before and after 2008

\begin{tabular}{|c|c|c|c|c|}
\hline & Minimum & Geometric Mean & Maximum & $\%$ Change in Mean \\
\hline \multicolumn{5}{|l|}{ All Data } \\
\hline Before & \multirow{2}{*}{\multicolumn{4}{|c|}{$\mathrm{N} / \mathrm{A}$}} \\
\hline After & & & & \\
\hline \multicolumn{5}{|l|}{ Winter } \\
\hline Before & \multirow{2}{*}{\multicolumn{4}{|c|}{$\mathrm{N} / \mathrm{A}$}} \\
\hline After & & & & \\
\hline \multicolumn{5}{|l|}{ Spring } \\
\hline Before & \multirow{2}{*}{\multicolumn{4}{|c|}{$N / A$}} \\
\hline After & & & & \\
\hline \multicolumn{5}{|l|}{ Summer } \\
\hline Before & 0.02 & 0.04 & 0.07 & \multirow{2}{*}{$+50 \%$} \\
\hline After & 0.05 & 0.06 & 0.07 & \\
\hline \multicolumn{5}{|l|}{ Fall } \\
\hline Before & \multirow{2}{*}{\multicolumn{4}{|c|}{$\mathrm{N} / \mathrm{A}$}} \\
\hline After & & & & \\
\hline
\end{tabular}




\section{Total Suspended Solids (TSS)}

(No before and after data to compare)

\section{Biological Oxygen Demand (BOD)}

(No before and after data to compare)

\section{Chemical Oxygen Demand (COD)}

(No before and after data to compare) 